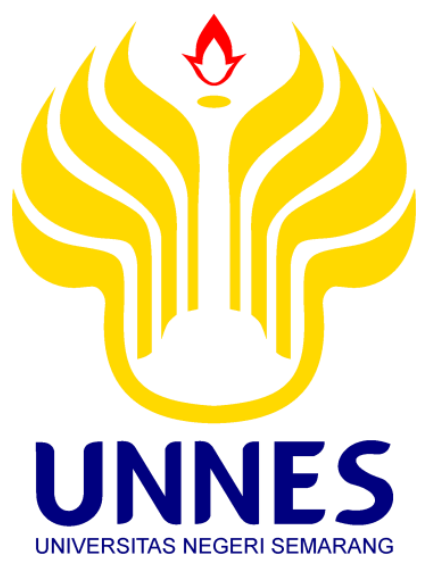

\title{
ESTETIKA BENTUK PERTUNJUKAN TARI LENGGANG PARI DI SANGGAR SENI PERWITASARI KELURAHAN KEMANDUNGAN KECAMATAN TEGAL BARAT KOTA TEGAL
}

\author{
SKRIPSI \\ untuk memperoleh gelar Sarjana Pendidikan \\ oleh \\ Nama : Devvi Lutfiana \\ NIM $\quad: 2501413072$ \\ Program Studi : Pendidikan Seni Tari \\ Jurusan : : Sendratasik
}

FAKULTAS BAHASA DAN SENI

UNIVERSITAS NEGERI SEMARANG 


\section{PERSETUJUAN PEMBIMBING}

Skripsi yang berjudul Estetika Bentuk Pertunjukan Tari Lenggang Pari di Sanggar Seni Perwitasari Kelurahan Kemandungan Kecamatan Tegal Barat Kota Tegal telah disetujui oleh dosen pembimbing untuk diajukan ke Sidang Panitia Ujian Skripsi Jurusan Pendidikan Seni Drama, Tari dan Musik Fakultas Bahasa dan Seni Universitas Negeri Semarang.

Semarang, 01 November 2017

Dosen Pembimbing I,

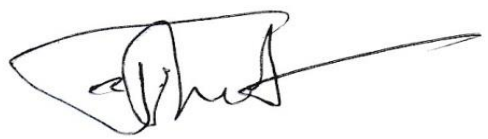

Drs. R. Indriyanto, M.Hum NIP. 196509231990031001
Dosen Pembimbing II,

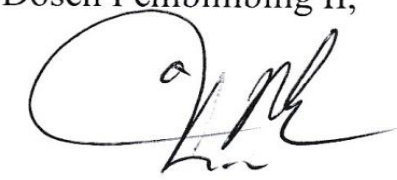

Utami Arsih, S.Pd, M.A NIP. 197001051998032001 


\section{PENGESAHAN KELULUSAN}

Skripsi ini telah dipertahankan di hadapan sidang Panitia Ujian Skripsi Jurusan Pendidikan Seni Drama, Tari dan Musik, Fakultas Bahasa dan Seni, Universitas Negeri Semarang

$$
\begin{aligned}
& \text { pada hari } \quad \text { Kamis } \\
& \text { tanggal } \quad: 9 \text { November } 2017 \\
& \text { Panitia Ujian Skripsi }
\end{aligned}
$$

Drs. Syahrul Syah Sinaga, M.Hum.

NIP. 196408041991021001

Ketua

Abdul Rachman, S.Pd.,M.Pd.

NIP. 198001202006041002

Sekretaris

Dra. V. Eny Iryanti, M.Pd.

NIP. 195802101986012001

Penguji I

Utami Arsih, S.Pd.,M.A.

NIP. 197001051998032001

Penguji II/Pembimbing II

Drs. R. Indriyanto, M.Hum.

NIP. 196509231990031001

Penguji III/Pembimbingt

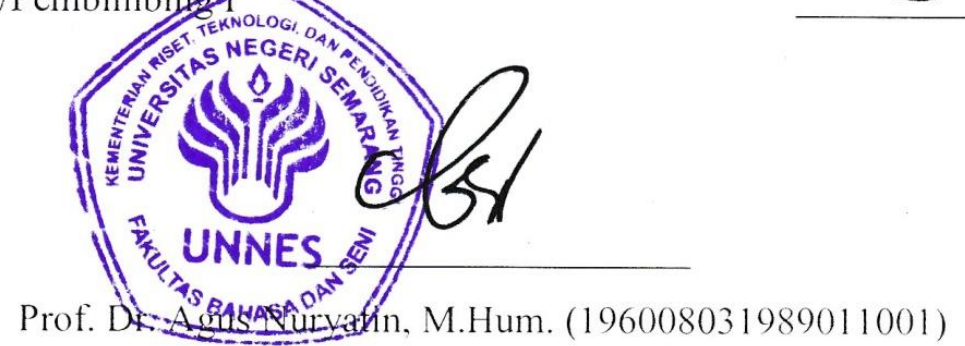

Dekan Fakultas Bahasa dan Seni
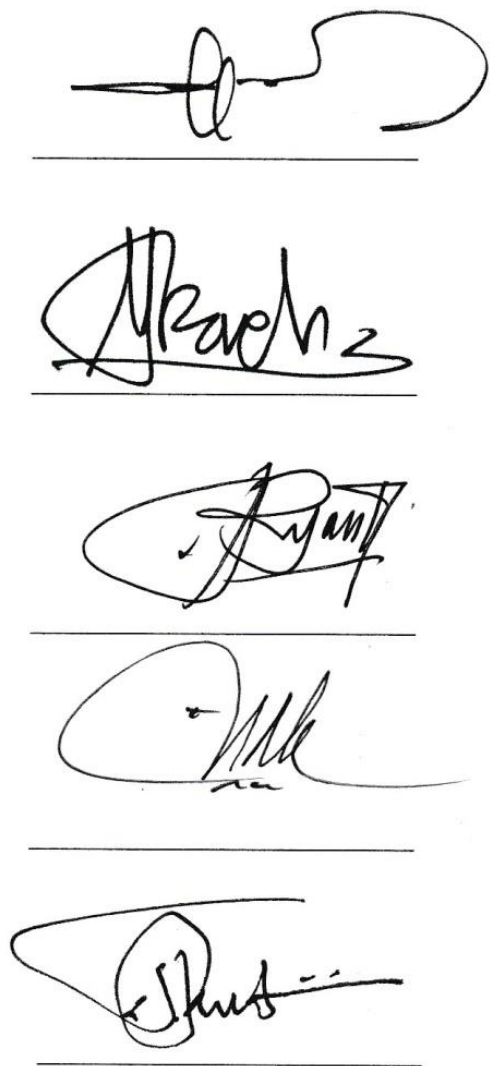


\section{PERNYATAAN}

Saya menyatakan bahwa yang tertulis di dalam skripsi "Estetika Bentuk Pertunjukan Tari Lenggang Pari di Sanggar Seni Perwitasari Kelurahan Kemandungan Kecamatan Tegal Barat Kota Tegal" benar-benar hasil karya saya sendiri, bukan jiplakan dari karya orang lain, baik sebagian atau seluruhnya. Pendapat atau temuan orang lain yang terdapat dalam skripsi ini dikutip atau dirujuk berdasarkan kode etik ilmiah.

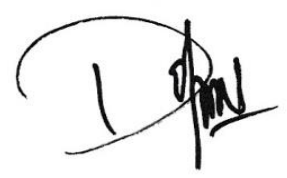

Devvi Lutfiana

NIM. 2501413072 


\section{MOTTO DAN PERSEMBAHAN}

Motto:

Semua apa yang telah ditetapkan oleh Allah adalah sebuah rezeki meski jalanNya tidak pernah kita ketahui sama sekali dan tidak selamanya perjalanan itu mudah, rezeki adalah anugrah Allah kepada hambanya yang senantiasa harus disyukuri karena Allah tidak lebih jauh dari urat leher kita. (Devvi Lutfiana)

"Beauty is unity of format relation among our sence perceptions" artinya, "keindahan adalah suatu kesatuan hubungan-hubungan yang formal dari pada pengamatan yang dapat menimbulkan rasa senang”. (Hebert Read)

Persembahan:

1. Untuk Jurusan Seni Drama Tari dan Musik

2. Untuk Bapak/Ibu dosen pembimbing skripsi

3. Untuk Bapak dan Ibuku tercinta

4. Untuk keluarga Sanggar Seni Perwitasari 


\title{
SARI
}

\author{
Lutfiana, Devvi. 2017. Estetika Bentuk Pertunjukan Tari Lenggang Pari di \\ Sanggar Seni Perwitasari Kelurahan Kemandungan Kecamatan Tegal \\ Barat Kota Tegal. Skripsi. Jurusan Pendidikan Seni Drama Tari dan \\ Musik, Fakultas Bahasa dan Seni, Universitas Negeri Semarang. \\ Pembimbing I: Drs. R. Indriyanto, M.Hum. Pembimbing II: Utami \\ Arsih, S.Pd, M.A. \\ Kata kunci: Estetika, Bentuk Pertunjukan, Tari Lenggang Pari
}

Tari Lenggang Pari merupakan komposisi tari berpasangan putra dan putri. Tari Lenggang Pari menggambarkan aktifitas bercocok tanam. Tari Lenggang Pari ditarikan oleh penari putra dan putri sebagai wujud dari lambang kesuburan yang berkaitan erat dengan kemakmuran masyarakat. Estetika bentuk pertunjukan tari Lenggang Pari dapat dilihat dari pola pertunjukan dan elemen pertunjukan tari Lenggang Pari. Masalah yang dikaji adalah bentuk tari Lenggang Pari dan nilai keindahan bentuk tari Lenggang Pari di Sanggar Seni Perwitasari Kelurahan Kemandungan Kecamatan Tegal Barat Kota Tegal. Penelitian ini bertujuan untuk mengetahui dan mendeskripsikan bentuk dan nilai keindahan tari Lenggang Pari yang dapat dilihat melalui pola pertunjukan dan elemen pertunjukan tari Lenggang Pari. Manfaat penelitian dari penelitian ini yaitu untuk menambah wawasan serta memberikan motivasi, mengenal, mempelajari, dan melestarikan kesenian daerah Kota Tegal yaitu tari Lenggang Pari.

Metode penelitian yang digunakan adalah metode penelitian kualitatif dengan pendekatan yang digunakan adalah pendekatan deskriptif kualitatif, pendekatan estetis koreografis dan pendekatan emik \& etik. Lokasi penelitian terletak di Kelurahan Kemandungan Kecamatan Tegal Barat Kota Tegal tepatnya di Sanggar Seni Perwitasari. Pengumpulan data dalam penelitian ini menggunakan metode observasi, wawancara dan dokumentasi. Teknik analisa data menggunakan analisa tari menurut konsep Janet Adshead. Teknik pemeriksaan keabsahan data dilakukan dengan meliputi uji kredibilitas dan dilakukan dengan triangulasi diartikan sebagai pengecekan data dari berbagai sumber dengan cara dan berbagai waktu.

Berdasarkan hasil analisis data, hasil temuan dari pertunjukan tari Lenggang Pari menunjukan bahwa estetika bentuk pertunjukan tari Lenggang Pari dapat dilihat dari pola pertunjukan dan elemen pertunjukan tari Lenggang Pari. Bentuk pertunjukan tari Lenggang Pari nampak pada pola pertunjukannya yang terdiri dari bagian awal, bagian inti, dan bagian akhir. Serta, elemen pertunjukan yang mendukung pertunjukan tari Lenggang Pari yang terdiri dari tema, alur cerita/alur dramatik, gerak, penari, pola lantai, ekspresi wajah/polatan, tata rias, tata busana, iringan/musik, setting panggung, properti dan pencahayaan.

Tari Lenggang Pari sebagai salah satu bentuk tari kerakyatan dari Kota Tegal. Walaupun merupakan tarian kreasi baru diharapkan mampu menggugah semangat generasi muda untuk mempelajari, mencintai, melestarikan serta mengenalkan salah satu bentuk kebudayaan daerah Kota Tegal. 


\section{PRAKATA}

Alhamdulillah, puji syukur peneliti panjatkan kehadirat Allah SWT yang telah melimpahkan Rahmat dan Hidayah-Nya, sehingga peneliti dapat menyelesaikan penyusunan skripsi yang berjudul "Estatika Bentuk Pertunjukan Tari Lenggang Pari di Sanggar Seni Perwitasari Kelurahan Kemandungan Kecamatan Tegal Barat Kota Tegal”, yang telah terselesaikan dengan baik.

Peneliti menyadari sepenuhnya bahwa penyusunan skripsi ini tidak lepas dari bantuan dan bimbingan baik materiil maupun spiritual dari berbagai pihak. Sehubungan dengan itu, dalam kesempatan ini peneliti hendak menyampaikan ucapan terimakasih kepada yang terhormat:

1. Prof. Dr. Fathur Rokhman, M.Hum., Rektor Universitas Negeri Semarang yang telah memberikan kesempatan studi di Jurusan Pendidikan Sendratasik Fakultas Bahasa dan Seni Universitas Negeri Semarang.

2. Prof. Dr. Agus Nuryatin, M.Hum., Dekan Fakultas Bahasa dan Seni (FBS) Universitas Negeri Semarang yang telah memberikan izin penelitian.

3. Dr. Udi Utomo, M.Si., Ketua Jurusan Pendidikan Sendratasik Universitas Negeri Semarang yang telah memberikan kesempatan kepada penulis dalam penyusunan skripsi ini.

4. Drs. R. Indriyanto, M.Hum., Dosen pembimbing I yang telah banyak meluangkan waktu dan tenaga untuk membimbing dan memberikan saran dan motivasi selama penyusunan skripsi. 
5. Utami Arsih, S.Pd, M.A., Dosen pembimbing II yang telah banyak meluangkan waktu dan tenaga untuk membimbing dan memberikan saran dan motivasi selama penyusunan skripsi.

6. Segenap Dosen dan Staf Pendidikan Seni Drama, Tari dan Musik yang telah membagi ilmu pengetahuan dan ketrampilan selama masa studi S1.

7. Keluarga tercinta (Bapak, Ibu, dan Adik) yang telah memberikan dukungan dan motivasi baik materil maupun moral demi kelancaran penyusunan skripsi ini.

8. Keluarga Sanggar Seni Perwitasari yang telah memberikan kesempatan, dukungan dan motivasi dalam penelitian tari Lenggang Pari.

9. Bapak Priambodo dan Ibu Damayanti selaku pencipta dan penata tari Lenggang pari serta pemilik Sanggar Seni Perwitasari di Kelurahan Kemandungan Kecamatan Tegal Barat Kota Tegal yang telah membantu memberikan data informasi yang diperlukan selama penelitian.

10. Penari Lenggang Pari Zulfa, Dimas, Wike, Deri dan pemusik Fatkhudin Nugroho yang telah banyak membantu dalam memberikan informasi dan proses pengambilan data yang dibutuhkan selama penyusunan skripsi ini.

11. Teman-teman Seni Tari Angkatan 2013 dan keluarga besar Sendratasik yang selama ini menemani belajar di Universitas Negeri Semarang.

Semarang, 01 November 2017

\section{Peneliti}




\section{DAFTAR ISI}

HALAMAN JUDUL .................................................................... i

PERSETUJUAN PEMBIMBING .................................................. ii

PENGESAHAN KELULUSAN _....................................................... iii

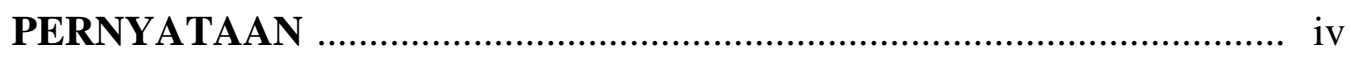

MOTTO DAN PERSEMBAHAN ............................................. v

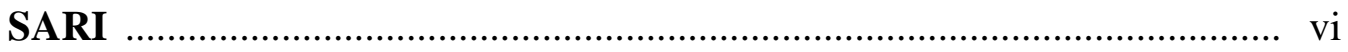

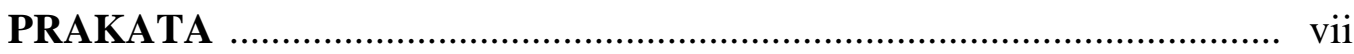

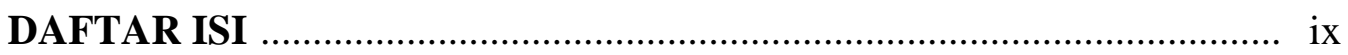

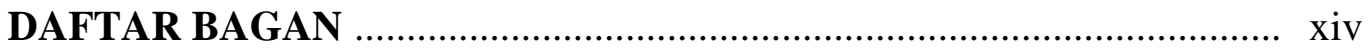

DAFTAR TABEL

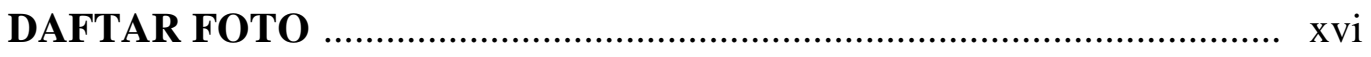

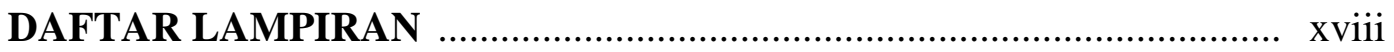

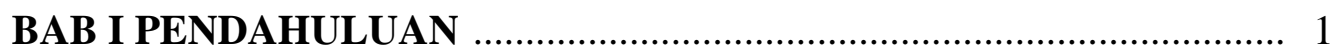

1.1 Latar Belakang Masalah ............................................................. 1

1.2 Rumusan Masalah ......................................................................... 7

1.3 Tujuan Penelitian ............................................................................ 7

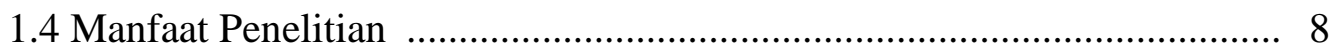

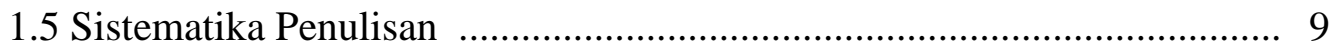

BAB II TINJAUAN PUSTAKA DAN LANDASAN TEORITIS ........... 11

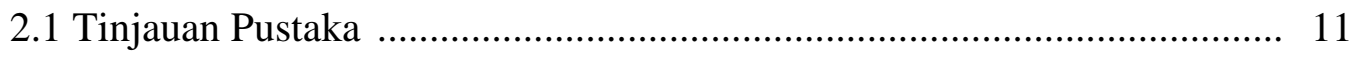

2.2 Landasan Teoritis ......................................................................... 15 
2.2.2 Nilai Estetika _......................................................................... 18

2.2.2.1 Keindahan Subjektif ............................................................ 21

2.2.2.2 Keindahan Objektif ................................................................. 23

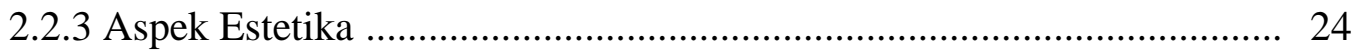

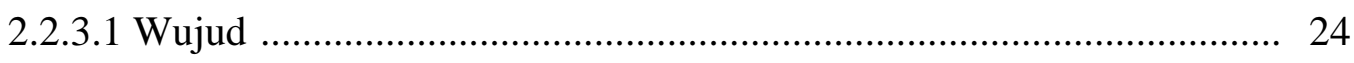

2.2.3.1.1 Bentuk (form) atau Unsur Mendasar ......................................... 25

2.2.3.1.2 Bentuk Tari ...................................................................... 25

2.2.3.1.3 Bentuk Pertunjukan ................................................................. 27

2.2.3.1.4 Susunan atau Struktur ........................................................... 31

2.2.4 Elemen Bentuk Pertunjukan ...................................................... 32

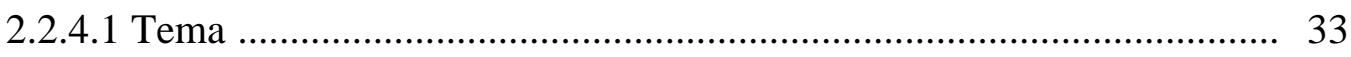

2.2.4.2 Alur Cerita ........................................................................ 33

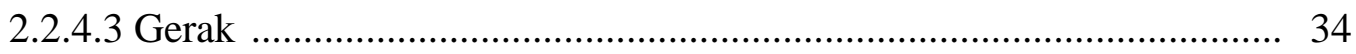

2.2.4.3.1 Nilai Keindahan Gerak ........................................................... 39

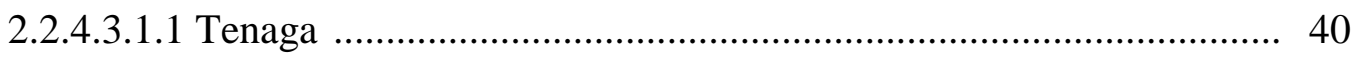

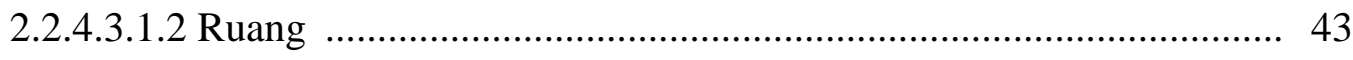

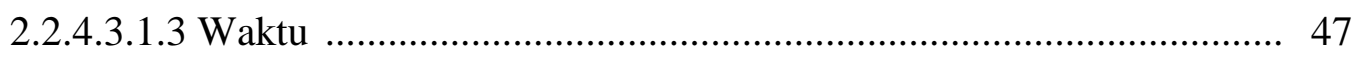

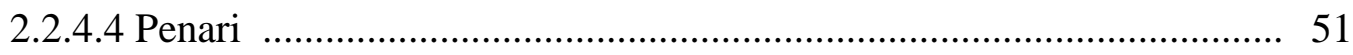

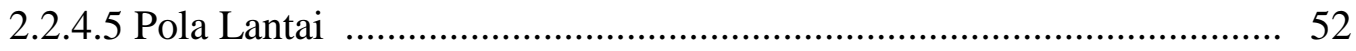

2.2.4.6 Ekspresi Wajah/Polatan ......................................................... 54

2.2.4.7 Tata Rias dan Busana ................................................................ 54

2.2.4.8 Tata Busana atau Kostum .......................................................... 57 


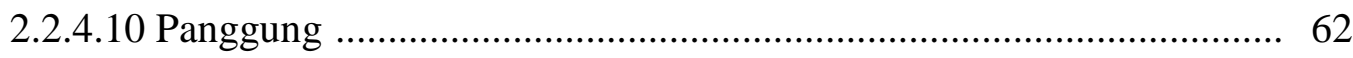

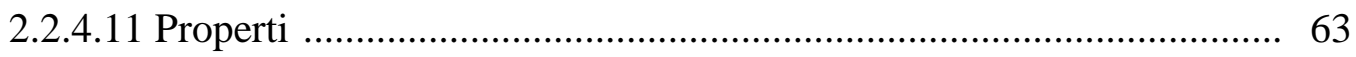

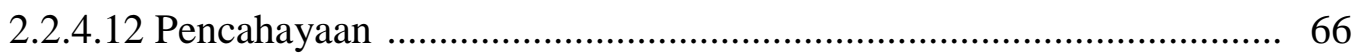

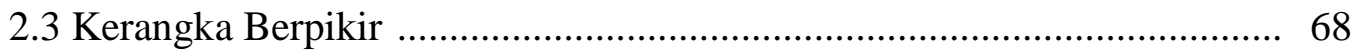

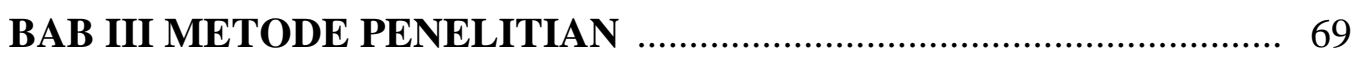

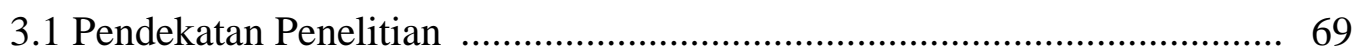

3.1.1 Pendekatan Deskriptif Kualitatif ................................................... 69

3.1.2 Pendekatan Estetis Koreografis .................................................. 72

3.1.3 Pendekatan Emik dan Etik ............................................................. 73

3.2 Lokasi dan Sasaran Penelitian ....................................................... 76

3.2.1 Lokasi Penelitian ........................................................................ 76

3.2.2 Sasaran Penelitian .................................................................. 76

3.3 Teknik Pengumpulan Data ........................................................... 77

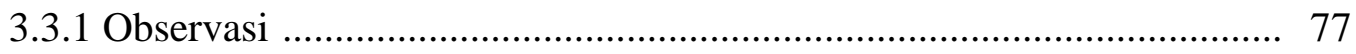

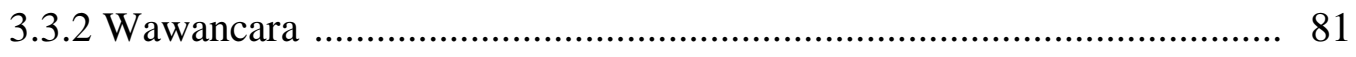

3.3.3 Dokumentasi ....................................................................... 84

3.4 Teknik Analisis Data ...................................................................... 85

3.5 Teknik Keabsahan Data ............................................................. 88

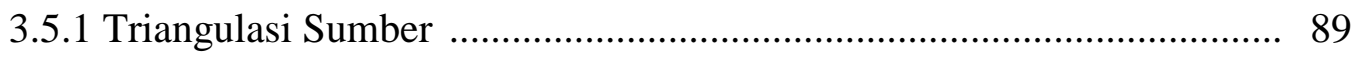

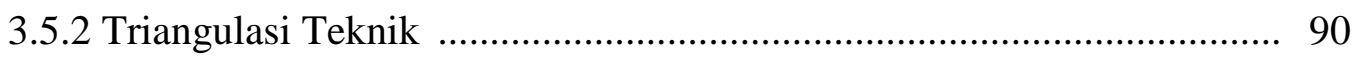

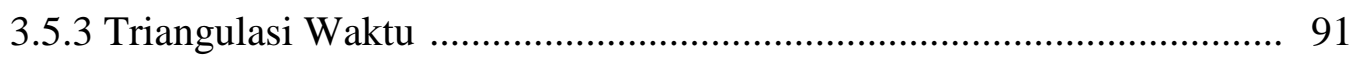


4.1 Gambaran Umum Lokasi Penelitian ...................................................... 92

4.1.1 Letak Geografis Lokasi Penelitian ................................................. 92

4.1.2 Kondisi Fisik Wilayah ................................................................... 93

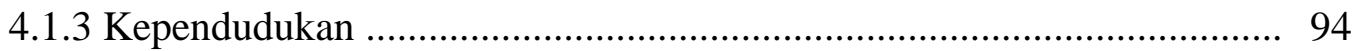

4.2 Sanggar Seni Perwitasari ................................................................ 99

4.3 Latar Belakang Tari Lenggang Pari ................................................. 104

4.4 Bentuk Pertunjukan Tari Lenggang Pari di Sanggar Seni Perwitasari

Kelurahan Kemandungan Kecamatan Tegal Barat Kota Tegal .............. 106

4.4.1 Pola Pertunjukan Tari Lenggang Pari di Sanggar Seni Perwitasari Kelurahan Kemandungan Kecamatan Tegal Barat Kota Tegal ............ 106

4.4.1.1 Bagian Awal Pertunjukan ........................................................ 106

4.4.1.2 Bagian Inti Pertunjukan ........................................................... 107

4.4.1.3 Bagian Akhir Pertunjukan .......................................................... 107

4.4.2 Elemen Pertunjukan Tari Lenggang Pari di Sanggar Seni Perwitasari Kelurahan Kemandungan Kecamatan Tegal Barat Kota Tegal ............ 108

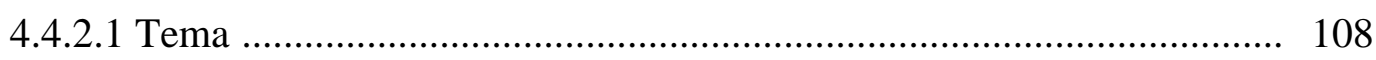

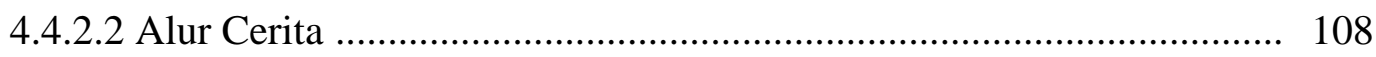

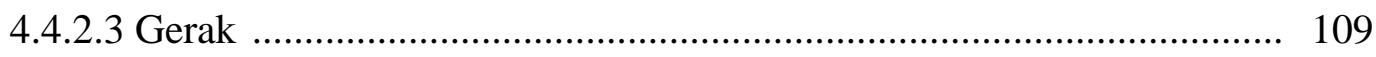

4.4.2.3.1 Deskripsi Ragam Gerak Tari Lenggang Pari ................................ 110

4.4.2.3.2 Unsur Gerak Tari Lenggang Pari ............................................. 126

4.4.2.3.3 Nilai Keindahan Gerak Tari Lenggang Pari ................................ 129

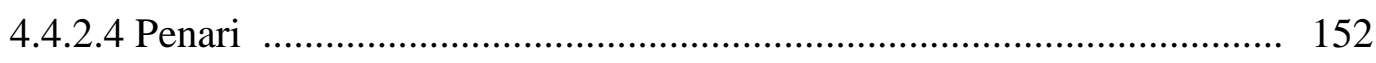




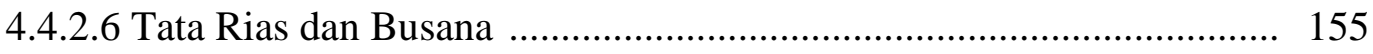

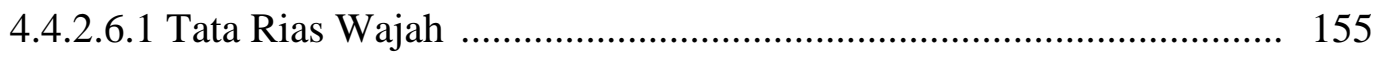

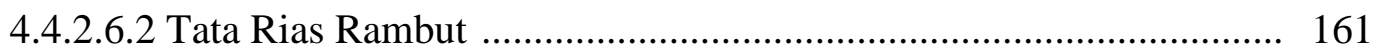

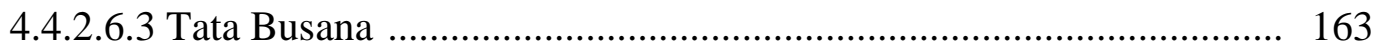

4.4.2.7 Iringan/Musik .................................................................... 176

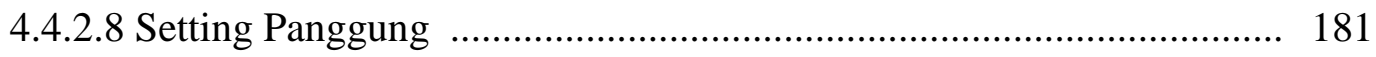

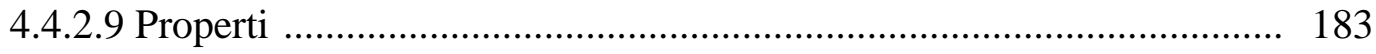

4.4.2.10 Tata Lampu dan Tata Suara ......................................................... 184

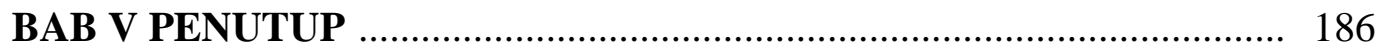

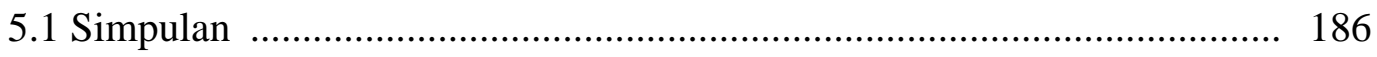

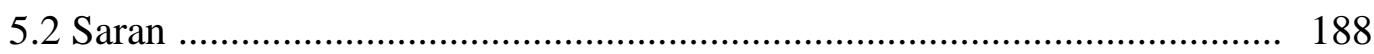

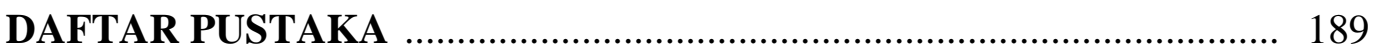

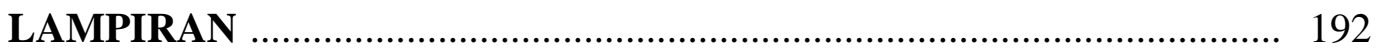

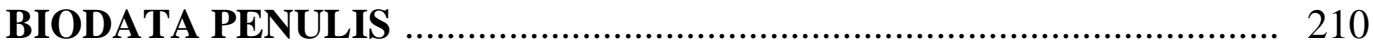




\section{DAFTAR BAGAN}

\section{Bagan}

Halaman

2.3 Kerangka Berpikir 68 


\section{DAFTAR TABEL}

Tabel

\section{Halaman}

4.1 Jumlah Penduduk Menurut Umur ....................................................... 94

4.2 Jumlah Penduduk Menurut Agama .................................................... 95

4.3 Jumlah Penduduk Menurut Mata Pencaharian ...................................... 96

4.4 Jumlah Penduduk Menurut Tingkat Pendidikan ................................... 97

4.5 Jumlah Fasilitas Umum ..................................................................... 98

4.6 Deskripsi Ragam Gerak Tari Lenggang Pari ........................................ 110

4.7 Unsur Gerak Kepala Tari Lenggang Pari ............................................ 126

4.8 Unsur Gerak Tangan Tari Lenggang Pari ........................................... 126

4.9 Unsur Gerak Badan Tari Lenggang Pari ........................................... 128

4.10 Unsur Gerak Kaki Tari Lenggang Pari .......................................... 128 


\section{DAFTAR FOTO}

Foto

Halaman

4.1 Lokasi Sanggar Seni Perwitasari _....................................................... 103

4.2 Tempat Berlatih Sanggar Seni Perwitasari ......................................... 103

4.3 Tempat Kostum Sanggar Seni Perwitasari ........................................... 104

4.4 Tempat Kostum Sanggar Seni Perwitasari ........................................... 104

4.5 Lumaksono Ngracik ................................................................... 131

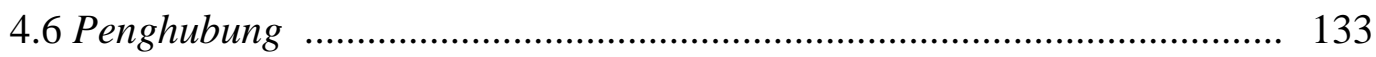

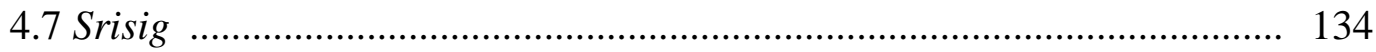

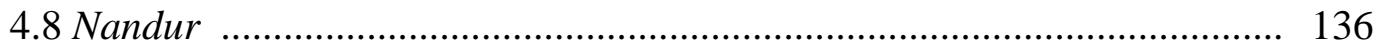

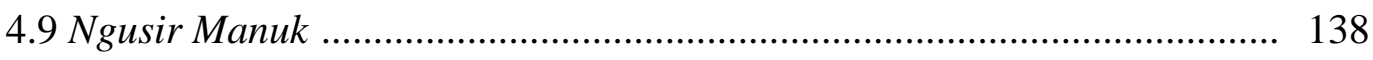

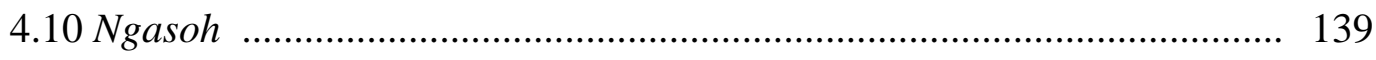

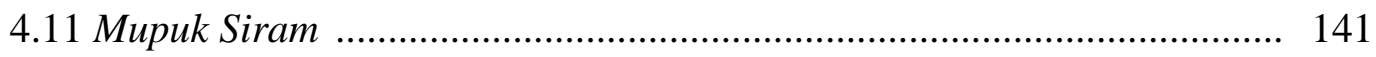

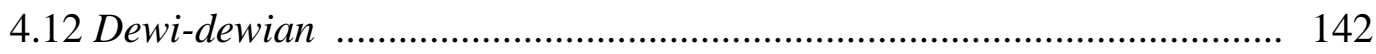

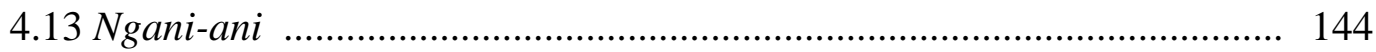

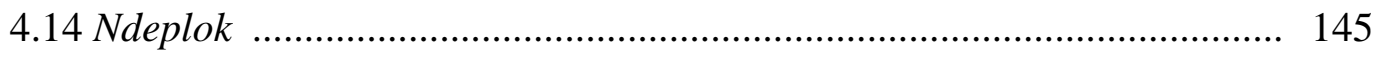

4.15 Lembehan Leyeh .................................................................... 147

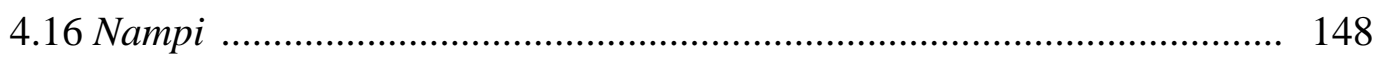

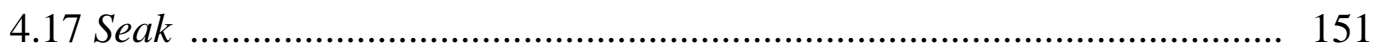

4.18 Alat dan Bahan Make Up ............................................................. 156

4.19 Tata Rias Wajah Penari Putri Tari Lenggang Pari .............................. 159

4.20 Tata Rias Wajah Penari Putra Tari Lenggang Pari ............................. 160

4.21 Cemara dan Aksesoris .................................................................. 161 
4.25 Kain Jarik Penari Putri Tari Lenggang Pari ...................................... 165

4.26 Streples atau Kamisol Putih ............................................................. 165

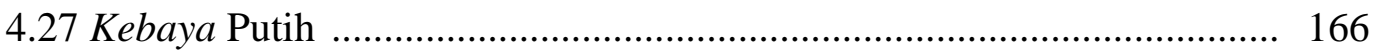

4.28 Slepe atau Sabuk Merah ................................................................. 166

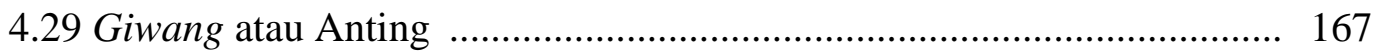

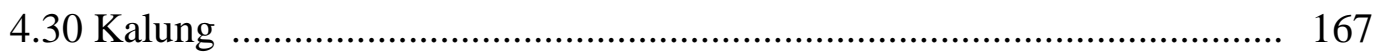

4.31 Tata Busana Penari Putri Tari Lenggang Pari ...................................... 169

4.32 Baju Lengan Panjang ................................................................. 170

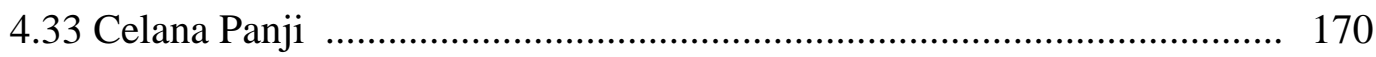

4.34 Kain Jarik Penari Putra Tari Lenggang Pari .................................... 171

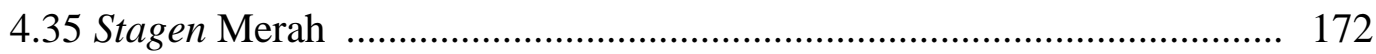

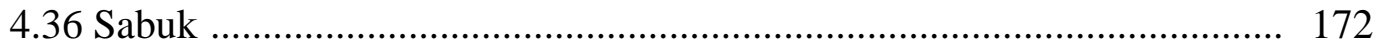

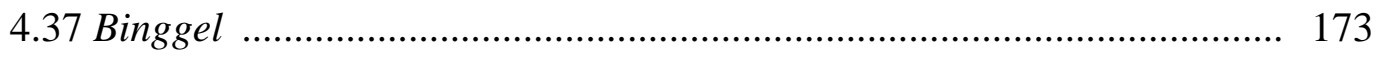

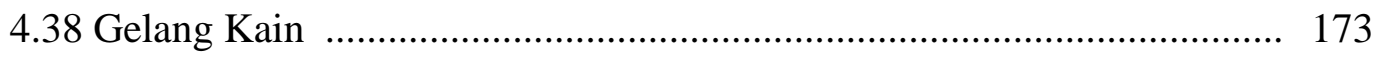

4.39 Tata Busana Penari Putra Tari Lenggang Pari ................................... 174

4.40 Panggung Pertunjukan ................................................................. 182

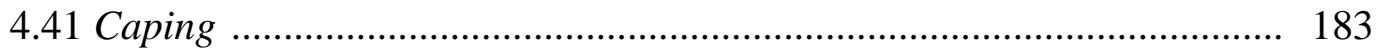

4.42 Tata Lampu dan Tata Suara …...................................................... 185 


\section{DAFTAR LAMPIRAN}

\section{Lampiran}

Halaman

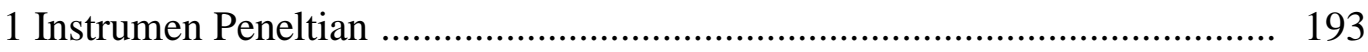

2 Surat Keterangan Dosen Pembimbing ................................................. 198

3 Surat Permohonan Izin Penelitian ...................................................... 199

4 Surat Keterangan Penelitian ........................................................... 201

5 Dokumentasi Pengambilan Data ......................................................... 203

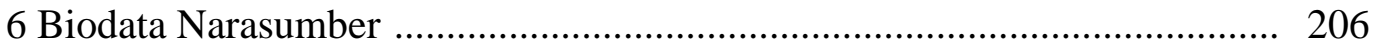

7 Data Daftar Nama Siswa di Sanggar Seni Perwitasari .............................. 208

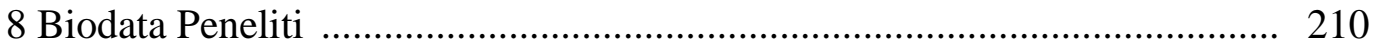




\section{BAB 1}

\section{PENDAHULUAN}

\subsection{Latar Belakang Masalah}

Seni adalah suatu ketrampilan yang diperoleh dari pengalaman, belajar, atau pengamatan-pengamatan. Seni adalah pengetahuan budaya, pelajaran, ilmu pengetahuan serta suatu pekerjaan yang membutuhkan pengetahuan atau ketrampilan dan imajinasi kreatif. Seni juga berarti suatu perencanaan yang mahir, dan menyatakan kualitasnya dengan baik, serta merupakan unsur-unsur yang ilustratif (Bahari 2008: 62-63).

Menurut The Liang Gie dalam Bahari (2008: 66-67) seni adalah suatu kemahiran atau kemampuan dari kegiatan manusia yang secara sadar dan melalui perantaraan tanda-tanda lahiriah tertentu, menyampaikan perasaan-perasaan yang telah dihayati kepada orang lain, sehingga mereka juga merasakan apa yang telah dirasakan oleh pencipta karya. Seni adalah suatu kegiatan manusia dalam menjelajahi dan menciptakan realita baru berdasarkan penglihatan yang irasional, sembari menyajikan realita itu secara simbolis karena seni merupakan kegiatan yang dirancang untuk mengubah bahan-bahan alamiah menjadi sesuatu yang berguna atau indah. Seni adalah suatu aktivitas kemanusiaan secara sadar menyangkut lambang-lambang atau simbol-simbol untuk menyampaikan perasaan tersebut dan ikut mengalaminya (Tolstoy dalam Bahari 2008: 73).

Keindahan ialah idea yang terwujud dan dapat ditangkap oleh indera. Seni ialah hubungan antara idea dengan indera. Bentuk hubungan itu disebut "simbolis", karena belum mencapai idealisme seni yang stabil (Hegel dalam 
Bahari 2008: 68). Indah adalah suatu kualitas yang membuat senang penginderaan dan kegembiraan batin. Sesuatu yang indah dapat memberikan perasaan senang inderawi dan kegembiraan jiwa (Sumardjo 2000: 155).

Seni ialah membangun perasaan yang dialami, lalu dengan perantaraan garis, warna, bunyi atau bentuk, mengungkapkan apa yang dirasakan sehingga orang lain tergugah perasaannya secara sama. Seni lahir sebagai sarana pemenuhan keinginan-keinginan bawah sadar. Karya seni adalah perwujudan terselubung dari keinginan itu (Bahari 2008:65).

Karya seni adalah bentuk ekspresi yang diciptakan bagi persepsi kita lewat indera dan pencitraan, dan yang diekspresikan adalah perasaan manusia. Seni adalah sebuah ekspresi perasaan seluruh umat manusia, dan bukan perasaan dirinya sendiri. Seni merupakan ciptaan, sesuatu yang tercipta berarti terwujud, yang tadinya tak ada menjadi ada. Seni adalah suatu ciptaan bentuk yang 'hidup', yang didalamnya ada dinamika, ada kesatuan logis dalam dirinya. Setiap karya seni harus bersifat organis, dinamis, hidup, penuh vitalitas. Suatu karya seni yang tak berhasil sering disebut karya yang 'mati', karena strukturnya tidak mengandung potensi mobilitas dan dalam hal bentuk ini dapat dikatakan sesuatu yang menyangkut nilai (Sumardjo 2000: 66-68).

Keindahan dalam seni dapat dilihat melalui proses bagaimana seni tercipta indah. Proses seni tercipta indah dapat dilihat melalui nilai intrinsik dan nilai ekstrinsiknya. Nilai keindahan intrinsik adalah nilai bentuk seni yang dapat diindera dengan mata, telinga, atau keduanya. Nilai bentuk ini kadang juga disebut nilai struktur, yakni bagaimana cara menyusun nilai-nilai ekstrinsiknya 
atau nilai bahannya. Nilai isi atau nilai ekstrinsik atau nilai bahanya berupa rangkaian peristiwa. Semuanya disusun begitu rupa sehingga menjadi sebuah bentuk yang berstruktur dan dinamai nilai intrinsik. Karya seni tetap harus mengandung keindahan, makna ekstrinsik itulah yang menyebabkan sebuah karya seni dikatakan indah, menyenangkan inderawi dan menggembirakan batin (Sumardjo 2000: 156-157).

Langer menyebutkan bahwa ranah pembahasan estetika adalah citra dinamis, kreasi, ekspresi, bentuk hidup, persepsi artistik dan "cahaya alami", pertalian yang logis dan nyata antar seni, imitasi dan transformasi, prinsip seni dan gambaran kreatifnya, simbol seni, serta kreasi puitis (Langer 2006: 15 ). Beberapa hal tersebut saling berkaitan satu sama lain dan pembahasannya tidak dapat dipisahkan. Jakob Sumarjo (2000: 10) dalam buku Filsafat Seni pada pokok bahasan seni menurut Langer, tiga prinsip mendasar dari konsep Langer adalah ekspresi, kreasi, dan bentuk seni.

Seni itu indah karena keindahan selalu lekat dengan aktivitas kesenian. Suatu kesenian menjadi indah karena ditata dan diolah melalui proses. Proses seni tercipta indah dapat dilihat dari bentuk, isi dan penampilan dari seni tersebut. Bentuk atau wujud dapat dilihat dari komponen-komponen pembentuk seni itu sendiri berupa aspek pokok dan aspek pendukungnya. Isi yang dimaksud meliputi ide gagasan, suasana, dan pesan yang terkandung didalamnya. Sedangkan melalui penampilan keindahan seni meliputi ketrampilan, bakat, sarana atau media pendukung sajian pertunjukan. Sarana atau media yang ada menimbulkan nilai artistik bagi para penikmatnya dengan ditandai dengan ciri khas atau karakter 
khusus dari suatu karya seni. Keindahan seni dapat dilihat dari bentuk, isi, dan penampilan (Djelantik 1999: 17-18).

Seni tari adalah gerak-gerak yang diberi bentuk ritmis dari badan di dalam ruang yang lahir dari desakan perasaan manusia yang dapat diserap melalui indera penglihatan, dimana keindahannya dapat dinikmati dari gerakan-gerakan tubuh, terutama gerakan kaki dan tangan, dengan ritme-ritme teratur, yang diiringi irama musik yang diserap melalui indera pendengaran (Bahari 2008: 57).

Seni tari adalah seni yang menggunakan gerakan tubuh secara berirama yang dilakukan di tempat dan waktu tertentu untuk keperluan mengungkapkan perasaan, maksud, dan fikiran. Seni tari merupakan salah satu bagian dari kebudayaan yang identik dengan nilai estetis, cipta, rasa dan karsa. Setiap tari yang diciptakan memiliki sisi keindahan yang khas menempel pada tari tersebut. Melalui sisi koreografinya sebuah tarian dapat diketahui keindahannya. Keindahan suatu tarian dapat ditelaah melalui bentuk dan isi tarian.

Seni tari dapat diserap secara visual dan audio. Estetika tari dilihat pertama kali oleh penonton dari penyajiannya, kemudian berlanjut pada konsep yang membangunnya. Prinsip-prinsip bentuk seni dan pengorganisasian bentuk akan digunakan untuk melihat sisi estetis dari segi bentuk tarinya, kemudian akan diamati kedalamannya menggunakan konsep Langer tentang citra dinamis, ekspresi, dan kreasi. Ketiga konsep Langer tersebut dipilih karena citra dinamis, ekspresi, dan kreasi manjadi „roh" yang dimiliki oleh suatu bentuk seni. Ketiga hal tersebut dirasa telah cukup untuk mengungkap suatu gagasan, konsep, ekspresi, yang tertuang dalam sebuah kreasi koreografer. Tari merupakan sebuah wujud 
yang diciptakan atas kreativitas dan ekspresi penciptanya. Koreografer dan penari memiliki kepaduan agar dapat menyampaikan makna atau maksud tarian itu, sehingga tarian menjadi "hidup" tidak sekedar tebakan gerak yang "mati " (Langer 2006: 20).

Keindahan setiap pertunjukan tari dari masing-masing daerah dapat berbeda-beda antara tari daerah yang satu dengan lainnya karena konsep keindahannya sudah berbeda. Perbedaan tari tersebut dapat dipengaruhi oleh beberapa faktor, diantaranya seperti pendidikan, sosial budaya, kondisi geografis, agama, dan penduduk. Berdasarkan faktor-faktor tersebut maka setiap bentuk pertunjukan tari masing-masing daerah memiliki ciri khas yang mewakili daerahnya dan nilai keindahan yang berbeda dari satu daerah dengan daerah lain demikian juga dengan tari Lenggang Pari.

Tari Lenggang Pari adalah sebuah tarian kreasi baru yang diciptakan pada akhir bulan November tahun 2015, Tari Lenggang Pari terinspirasi dari panen raya padi MSP seluruh Indonesia yang diadakan di Kota Cirebon. Tari Lenggang Pari merupakan komposisi tari duet berpasangan putra dan putri. Tari berpasangan ini merupakan bentuk tari pergaulan yang disajikan untuk menghibur penonton. Tarian ini menggambarkan aktifitas bercocok tanam pada masyarakat yang bekerja sebagai petani. Lenggang dalam tarian ini diartikan sebagai aktifitas masyarakat dalam bertani, tari Lenggang Pari disajikan oleh penari putra dan putri sebagai wujud dari lambang kesuburan yang berkaitan erat dengan kemakmuran masyarakat melalui hasil panen padi MSP yang berlimpah. Tari Lenggang Pari merupakan ekspresi jiwa, konsep, atau gagasan seniman pelakunya (penari dan 
musisi) yang diungkapkan dengan bentuk pola pengaturan ritme gerak dan pola ruang secara berpasangan oleh penarinya. Tari Lenggang Pari dapat dikategorikan sebagai tari tradisional kerakyatan. Tari tradisional kerakyatan adalah tari yang tumbuh secara turun temurun dari satu generasi ke generasi selanjutnya dalam lingkungan masyarakat etnis, atau berkembang dalam rakyat (Hidajat 2005:14). Menurut Maryono (2012: 25) jenis tari rakyat biasanya mempunyai bentuk sederhana pada elemen pertunjukannya.

Tari Lenggang Pari mempunyai nilai keindahan yang khas. Nilai Keindahan tersebut bisa dilihat pada keunikan yang terdapat pada tari Lenggang Pari. Tari Lenggang Pari mempunyai konsep $d w i$ karsa yang berarti kesatuan dua unsur kehendak dalam kehidupan. Keunikan tari Lenggang pari dapat dilihat melalui segi bentuk pertunjukannya, pada ragam gerak dewi-dewian penari putra mengangkat penari putri serta melakukan gerak sembahan sebagai wujud rasa hormat kepada sang pencipta dan kasih sayang terhadap pasangan. Warna busana tari Lenggang Pari yang didominasi warna merah dan putih pada konsep $d w i$ karsa mempunyai maksud sebagai perlambangan benih ibu dan bapak. Penggunaan tembang suluk tegalan dan gendhing lancaran lesung jumengglung slendro sanga yang berarti seorang petani harus ikhlas, mempunyai semangat juang yang tinggi dalam kerja kerasnya bercocok tanam agar kehidupan tetap berlangsung. Keunikan dilihat dari bentuk dapat dianalisis melalui gerak, rias wajah, tata busana, iringan tari, pelaku/penari, tempat pentas, tata lampu dan tata suara yang mendukung pertunjukan tari Lenggang Pari. 
Berpijak pada hal tersebut penelitian ini ingin mengupas estetika bentuk pertunjukan dengan mengungkap elemen-elemen pertunjukan tari yang terdiri dari aspek pokok dan aspek pendukung dalam tari Lenggang Pari untuk menghubungkan antar elemen tari sehingga memperoleh nilai keindahan bentuk pertunjukan tari Lenggang Pari di Sanggar Seni Perwitasari Kelurahan Kemandungan Kecamatan Tegal Barat Kota Tegal.

\subsection{Rumusan Masalah}

Berdasarkan latar belakang di atas, maka dapat ditarik rumusan masalah yaitu: Bagaimana Estetika Bentuk Pertunjukan Tari Lenggang Pari di Sanggar Seni Perwitasari Kelurahan Kemandungan Kecamatan Tegal Barat Kota Tegal dengan kajian pokok:

a. Bagaimana bentuk tari Lenggang Pari di Sanggar Seni Perwitasari Kelurahan Kemandungan Kecamatan Tegal Barat Kota Tegal ?

b. Bagaimana nilai keindahan bentuk tari Lenggang Pari di Sanggar Seni Perwitasari Kelurahan Kemandungan Kecamatan Tegal Barat Kota Tegal ?

\subsection{Tujuan Penelitian}

Berdasarkan rumusan masalah di atas maka tujuan yang hendak dicapai dari penelitian ini adalah untuk mengetahui dan mendeskripsikan Estetika Bentuk Pertunjukan Tari Lenggang Pari Di Sanggar Seni Perwitasari Kelurahan Kemandungan Kecamatan Tegal Barat Kota Tegal dengan tujuan kajian pokok :

a. Mengetahui dan mendeskripsikan bentuk tari Lenggang Pari di Sanggar Seni Perwitasari Kelurahan Kemandungan Kecamatan Tegal Barat Kota Tegal. 
b. Mengetahui dan mendeskripsikan nilai keindahan bentuk tari Lenggang Pari di Sanggar Seni Perwitasari Kelurahan Kemandungan Kecamatan Tegal Barat Kota Tegal.

\subsection{Manfaat Penelitian}

Manfaat dari hasil penelitian terbagi menjadi dua golongan yaitu manfaat teoritis dan manfaat praktis. Adapun manfaat penelitian diantaranya sebagai berikut :

\section{a. Manfaat Teoretis}

1) Hasil penelitian dapat dijadikan sebagai sumbangan pikiran dan menambah pengetahuan kepada masyarakat luas terutama mahasiswa seni tari UNNES agar mengetahui dan mengenal tari gaya Tegalan yang ada di Kota Tegal.

2) Hasil Penelitian sebagai pelengkap pengetahuan mengenai nilai estetika dalam suatu penyajian pertunjukan kesenian tradisional.

\section{b. Manfaat Praktis}

1) Bagi Peneliti

Hasil penelitian dapat dijadikan sebagai bahan informasi penelitian yaitu untuk menambah pengetahuan dan wawasan tentang kesenian tari Lenggang Pari khususnya yang ada di Sanggar Seni Perwitasari Kelurahan Kemandungan Kecamatan Tegal Barat Kota Tegal.

2) Bagi Kelompok Kesenian

Hasil penelitian dapat memberi manfaat bagi kelompok kesenian agar tetap mempertahankan kualitas pertunjukan dan kreativitas garapan agar kesenian yang ditampilkan tetap dicintai masyarakat. 
3) Bagi Masyarakat

Hasil penelitian dapat menambah wawasan dan mampu memberikan kontribusi serta pandangan dari segi estetika kepada masyarakat luas melalui karya tulis pada tari Lenggang Pari yang ada di Kota Tegal. Memberi informasi yang lengkap dan mengenalkan suatu karya tari baru kepada masyarakat yang memiliki partisipasi untuk ikut andil melestarikan dan mengembangkan tari Lenggang Pari di Kota Tegal.

\subsection{Sistematika Penulisan Skripsi}

Sistematika skripsi disusun dengan tujuan agar pokok-pokok masalah dapat dibahas secara urut dan terarah. Adapun sistematika penulisan skripsi ini terdiri dari:

1.5.1 Bagian awal berisi tentang halaman judul, pengesahan, penguji, motto dan persembahan, sari, prakata, daftar isi, daftar bagan, daftar tabel, daftar gambar, serta daftar lampiran.

1.5.2 Bagian isi skripsi terdiri dari 5 bab yaitu:

Bab I Pendahuluan yang berisi tentang alasan pemilihan judul, rumusan masalah, tujuan penelitian, manfaat penelitian, sistematika penulisan skripsi.

Bab II Landasan teoretis dan kajian pustaka berisi teori pendukung yaitu konsep estetika, nilai estetika, aspek estetika, elemen-elemen bentuk pertunjukan, kajian pustaka, kerangka berpikir. 
Bab III Metode penelitian berisi tentang pendekatan penelitian menjadi data dan sumber data, teknik pengumpulan data, teknik analisa data, teknik keabsahan data.

Bab IV Hasil penelitian dan pembahasan yang mencakup tentang gambaran umum lokasi penelitian, latar belakang pertunjukan tari Lenggang Pari, bentuk pertunjukan tari Lenggang Pari, urutan penyajian tari Lenggang Pari dan nilai bentuk pertunjukan tari Lenggang Pari.

Bab V Berisi simpulan dan saran hasil penelitian

1.5.3. Bagian akhir berisi daftar pustaka yang berkaitan dengan penelitian dan lampiran yang memuat kelengkapan penelitian. 


\section{BAB II}

\section{TINJAUAN PUSTAKA DAN LANDASAN TEORETIS}

\subsection{Tinjauan Pustaka}

Landasan dalam penelitian menggunakan teori-teori dan konsep-konsep yang disusun sendiri secara elektrik maupun teori yang digunakan oleh seorang ahli. Teori yang digunakan dipertanggungjawabkan melalui kajian sejumlah pustaka yang memuat hasil penelitian dalam lingkup topik penelitian yang menggunakan teori terpilih ataupun yang menggunakan teori yang berbeda. Pustaka yang dikaji dapat berupa buku, artikel dalam jurnal ilmiah, makalah skripsi, tesis, disertasi, dan laporan penelitian. Pustaka yang digunakan harus relevan dengan topik penelitian, maka peneliti menggunakan beberapa buku dan penelitian relevan sebagai landasan teoretis.

Peneliti menggunakan beberapa artikel dalam jurnal ilmiah yang dijadikan sumber acuan landasan teoretis, beberapa diantaranya artikel dengan judul Kajian Nilai Estetis Tari Rengga Manis di Kabupaten Pekalongan dalam jurnal seni tari Unnes Volume 5 Nomor 1 tahun 2016. Hasil penelitian menunjukan bahwa nilai estetis tari Rengga Manis juga dapat dilihat dari komponen pendukung koreografi seperti rias dan busana tari, iringan, isi tari yang terdiri dari suasana, gagasan, pesan serta yang terakhir yaitu penampilan terdiri dari wiraga, wirama, dan wirasa. Dilihat dari geraknya memunculkan kesan lembut, terlihat lincah saat gerakan dengan tekanan yang kuat dan tempo cepat. Hal ini terlihat salah satunya pada gerakan goyang pinggul yang menggunakan kekuatan pinggul yang digerakkan secara cepat dan berulang-ulang. Tarian ini menggunakan iringan 
"Renggong Manis" dengan ciri khas pada kendhang dan bonang yang merupakan campuran cengkok Solo, Banyumas dan Sunda. Pekalongan menggunakan notasi $j i$ yang diganti pi sehingga menghasilkan nada yang rancak dan menarik. Didukung dengan busana yang dipakai menggunakan perpaduan warna hijau yang memberikan kesan ketenangan dan warna kuning yang memberikan kesan bahagia dan semangat.

Penelitian yang dilakukan oleh Agiyan Wiji Pritaria Arimbi yang berjudul Kajian Nilai Estetis Tari Megat-Megot di Kabupaten Cilacap dalam jurnal seni tari Unnes Volume 5 Nomor 1 tahun 2016. Hasil penelitian menunjukan bahwa nilai estetis Tari Megat-Megot di Kabupaten Cilacap, meliputi aspek wujud, isi dan penampilan. Aspek wujud terdiri dari gerak, iringan, tata rias dan busana, properti serta pola lantai. Sedangkan aspek isi meliputi ide atau gagasan dan suasana. Aspek penampilan terdiri dari wiraga, wirama dan wirasa. Dilihat dari aspek gerak dalam pertunjukan Tari Megat-Megot kesan yang terlihat yaitu kesan dinamis, kesan tersebut muncul karena tempo dalam sajian Tari Megat-Megot banyak menggunakan tempo cepat dengan disertai penggunaan tenaga yang kuat. Penggunaan tempo cepat disertai tenaga yang kuat salah satunya terlihat dalam ragam gerak obah bahu dengan sikap badan mayuk dan kaki mendhak, keseimbangan tubuh disertai penggunaan tenaga yang kuat menjadikan ragam gerak ini terlihat sangat dinamis. Selain itu kesan dinamis dalam Tari MegatMegot muncul karena penggunaan iringan tari dari instrumen gamelan calung yang keras disertai tempo cepat dan penggunaan dialek Banyumas dalam tembang iringan Tari Megat-Megot. Penggunaan rias dan busana menjadi aspek pendukung 
penampilan para penari, warna busana yang cerah dengan dominan warna orange menimbulkan kesan ceria dan natural.

Peneliti juga menggunakan beberapa penelitian relevan yang dijadikan sumber acuan tinjauan pustaka, beberapa diantaranya adalah penelitian Isti Komariyah (skripsi 2016) dengan judul Nilai Estetika Barongan Wahyu Arom Joyo Di Desa Gunungsari Kecamatan Tlogowungu Kabupaten Pati. Hasil penelitian menunjukan bahwa nilai estetika Barongan dapat dilihat dari bentuk, isi dan penampilan. Nilai estetis Barongan dari segi bentuk pertunjukannya nampak pada gerak yang dilakukan penari Barongan yang lebih bersifat spontan dan lebih banyak melakukan improvisasi gerak dan mengikuti alunan iringan dengan alat musik yang menimbulkan kesan ramai. Koordinasi gerak antara pemain Barongan yang bertugas sebagai kepala dengan ekor yang seimbang akan nampak lebih indah. Ragam gerak yang terdapat dalam pertunjukan Barongan yang menimbulkan kesan dinamis, enerjik, gagah, dan mistis. Gerak yang dilakukan tari barongan cenderung berlevel rendah dengan ditambah ekspresi pembarong diwujudkan melalui gerak topeng Barongan seperti gerak spontan ke kanan dan kiri mengekspresikan Barongan yang sedang melihat suasana disekelilingnya juga untuk melihat mangsa. Bentuk topeng barong yang dipandu dengan kain motif bergaris seperti kulit hewan harimau lebih memberi kesan ganas dan garang Barongan sebagai penari utama. Tempat pertunjukkan Barongan di area terbuka dengan menggunakan pencahayaan dari lampu neon pada malam hari dan sinar matahari pada siang hari. Setting panggung dengan sesaji-sesaji menjadi salah satu cara kelompok Barongan untuk mempertahankan keaslian pertunjukan Barongan. 
Isi pertunjukan Barongan Wahyu Arom Joyo nampak pada gagasan, suasana dan pesan yang ada dalam pertunjukan Barongan. Pertunjukan Barongan Wahyu Arom Joyo bersumber dari cerita Geger Kediri. Cerita Barongan Geger Kediri dipadukan dengan lawakan guyon maton yaitu lawakan bebas yang berfungsi menghibur penonton. Pesan yang disampaikan dalam pertunjukan barongan ini melalui cerita yang diambil yaitu geger kediri dengan penggambaran kejahatan melawan kebaikan maka dimanapun kebaikan akan selalu menang sehingga penonton akan memperoleh nilai-nilai kehidupan dari pertunjukan Barongan yaitu nilai kerukunan, kebersamaan, sifat keteladanan, kegotong-royongan, keharmonisan, dan kebahagiaan. Penampilan kesenian Barongan Wahyu Arom Joyo nampak pada bakat, ketrampilan dan sarana atau media. Bakat yang dimiliki penari Barongan merupakan potensi kemampuan khas yang dimiliki oleh penari yang didapatkan berkat keturunannya. Ketrampilan penari Barongan menuju pertunjukan Barongan yang berkualitas dilakukan dengan dicapai dengan latihan baik latihan fisik maupun non fisik. Sarana atau media dalam pertunjukan Barongan terdiri dari tempat pertunjukan/panggung, pencahayaan, dan setting.

Demikian beberapa penelitian di atas memiliki persamaan dan perbedaan sendiri dengan penelitian yang dilakukan oleh peneliti. Beberapa penelitian memiliki persamaan yang terletak pada kajian yang ingin diteliti yaitu nilai estetis atau nilai keindahan sebagai subyek penelitian. Perbedaan yang benar-benar nampak dari beberapa penelitian di atas dengan penelitian yang akan dilakukan yaitu terletak pada objek penelitiannya. 


\subsection{Landasan Teoretis}

\subsubsection{Konsep Estetika}

Secara etimologis menurut Shipley (dalam Nyoman Kutha Ratna 2007: 3) estetika berasal dari bahasa yunani yaitu aistheta yang juga diturunkan dari aisthe (hal-hal yang dapat ditanggapi dengan indra, tanggapan indra). Pada umumnya aishte diposisikan dengan noeta, dari akar kata noein, nous, yang berarti hal-hal yang berkaitan dengan pikiran, dalam pengertian yang lebih luas berarti kepekaan untuk menanggapi suatu objek, kemampuan penerapan indra sebagai sensitivitas. Estetika berasal dari kata Yunani Aesthesis, yang berarti perasaan atau sensitivitas. Itulah sebabnya maka estetika erat sekali hubungannya dengan selera perasaan atau apa yang disebut dalam bahasa Jerman Geschmack atau Taste dalam bahasa Inggris (Bahari 2008: 169).

Estetika adalah suatu ilmu yang mempelajari segala sesuatu yang berkaitan dengan keindahan, mempelajari semua aspek yang disebut indah. Halhal yang indah dapat berupa keindahan alami maupun keindahan buatan. Pada umumnya apa yang kita sebut indah di dalam jiwa kita dapat menimbulkan rasa senang, rasa puas, rasa aman, nyaman dan bahagia, dan bila perasaan itu kuat, kita merasa terpaku, terharu, terpesona, serta menimbulkan keinginan untuk mengalami kembali perasaan itu, walaupun sudah menikmati berkali-kali (Djelantik 1999: 9).

Estetika dalam seni tari adalah sesuatu yang hanya bisa dinikmati dengan rasa. Rasa keindahan pada tari dapat terwujud melalui keutuhan penggarapan yang dapat menimbulkan rasa ketertarikan pada semua penikmatnya. Keutuhan 
penggarapan itu meliputi berbagai aspek yaitu keharmonisan, keseimbangan, dan penekanan (Made dan Utina 2007: 175). Estetika memberikan pedoman terhadap berbagai pola perilaku manusia yang berkaitan dengan keindahan, yang pada dasarnya mencakup kegiatan berkreasi dan berapresiasi. Pertama, estetika menjadi pedoman bagi seniman untuk mengekspresikan kreasi artistiknya. Kedua, estetika memberikan pedoman bagi penikmat untuk menyerap karya seni tersebut berdasarkan pengalamannya melakukan pengalaman estetik tertentu (Bahari 2008: 47).

Menurut Herimanto dan Winarno (2010: 30) estetika dapat dikatakan sebagai teori tentang keindahan atau seni. Estetika berkaitan dengan nilai indahjelek (tidak indah). Nilai estetik berarti nilai tentang keindahan. Keindahan dapat diberi makna secara luas, secara sempit, dan estetik murni. Secara luas yaitu keindahan mengandung ide kebaikan, secara sempit yaitu keindahan terbatas pada lingkup persepsi penglihatan (bentuk dan warna) dan secara estetik murni yaitu menyangkut pengalaman estetik seseorang dalam hubungannya dengan segala sesuatu yang diresapinya melalui penglihatan, pendengaran, perabaan dan perasaan, yang semuanya dapat menimbulkan persepsi (anggapan) indah.

Menurut Aristoteles (dalam Sumardjo 2000: 275) ciri-ciri lengkap keindahan, baik pada alam maupun pada karya seni, adalah :

a. Kesatuan atau keutuhan yang dapat menggambarkan kesempurnaan bentuk, tak ada yang berlebih atau berkurang. Sesuatu yang pas dan khas adanya.

b. Harmoni atau keseimbangan antar unsur-unsur yang proporsional, sesuai dengan ukuranya yang khas. 
c. Kejernihan, bahwa segalanya memberikan suatu kesan kejelasan, terang, jernih, murni tanpa ada keraguan.

Keindahan pada dasarnya bersumber pada dua faktor, yaitu faktor yang berasal dari kualitas objek (benda, peristiwa kesenian yang indah), dan faktor yang berasal dari cara kita dalam menangkap, merespons atau menanggapi keindahan (Jazuli 2008: 109). Kualitas estetika untuk dinikmati, dirasakan, dan dihayati bukan untuk dipikirkan (Kutha Ratna 2007: 17). Karya seni dapat dikatakan indah apabila setidak-tidaknya dalam segi atau unsurnya terdapat keindahan, di samping tarian itu sendiri harus juga mengandung isi, makna, atau pesan yang dikandungnya (Hadi 2005: 16).

Menurut Soetarno (2007: 17) di dalam kebudayaan Jawa, terutama yang terkait erat dengan ekspresi estetik, seperti wayang, batik, bangunan, tari dan gamelan mengandung ciri-ciri sebagai berikut :

1) Bersifat kontemplatif-transendental, yang berarti bahwa masyarakat Jawa mengungkapkan rasa keindahan yang terdalam, selalu mengaitkannya dengan perenungan yang mendalam. Rasa estetik masyarakat Jawa selalu terkait dengan ungkapan religius terhadap Tuhan Yang Maha Kuasa, rasa pengabdian total terhadap raja (penguasa), refleksi kecintaan terhadap negara, penghayatan yang mendalam terhadap alam semesta, yang kesemuanya itu merupakan pengejewantahan dari laku mistik orang Jawa.

2) Bersifat Simbolik, dalam arti bahwa masyarakat Jawa dalam segala tindakan berekspresi selalu mengandung makna simbolik, seperti dalam penggunaan tema yang diambil. 
3) Bersifat filosofis, dalam arti bahwa masyarakat Jawa dalam setiap tindakannya selalu didasarkan atas sikap tertentu yang dijabarkan dalam berbagai ungkapan hidup mereka.

\subsubsection{Nilai Estetika}

Nilai merupakan sesuatu yang diharapkan (das solen) oleh manusia. Nilai merupakan sesuatu yang baik yang dicitrakan manusia. Nilai menjadikan manusia terdorong untuk melakukan tindakan agar harapan itu terwujud dalam kehisupannya. Nilai diharapkan manusia sehingga mendorong manusia berbuat (Herimanto dan Winarno 2010: 128).

Nilai dapat diartikan sebagai martabat atau hakekat sesuatu nilai tidak tampak sebagai nilai bagi seseorang saja, melainkan bagi segala umat manusia, nilai hanya dapat dirasakan oleh setiap orang. Nilai tampil sebagai sesuatu yang patut dikerjakan dan dilaksanakan oleh semua orang, sebab nilai itu baik, oleh karena itu nilai dapat dikomunikasikan kepada orang lain (Mujiono dalam Fitri 2016: 45).

Nilai adalah sesuatu yang selalu bersifat subjektif, tergantung pada manusia yang menilainya. Nilai juga berkonteks praktis sesuatu dikatakan bernilai karena berguna dalam kehidupan. Nilai juga merupakan sesuatu yang ditambahkan pada suatu kenyataan, sedangkan kenyataan itu sendiri bebas nilai atau paling tidak hanya menyimpan sejumlah nilai. Nilai-nilai itu diperoleh dari lingkungan pergaulannya dari masyarakat. Nilai-nilai seni yang dimiliki oleh seseorang itu akibat pergaulan dan pendidikan. Pada dasarnya setiap nilai seni dari konteks mana pun memiliki yang tetap, setiap artefak seni mengandung 
aspek nilai ekstrinsik-intrinsik, yakni berupa bentuk-bentuk menarik atau indah. Nilai lain dalam karya seni adalah nilai kognitif atau pengetahuan. Nilai ini terbatas pada beberapa cabang seni saja. Musik misalnya, bermaterial bunyi, dan bunyi ini dimana pun sama kedengarannya, hanya alat yang menimbulkan bunyi itu yang bersifat konstektual. Nilai seni yang terakhir adalah nilai hidup. Nilai hidup yang dimaksud adalah nilai moral, nilai sosial, nilai politik, nilai agama, nilai psikologi. Nilai-nilai hidup ini yang bersifat universal (Sumardjo 2000: 135138).

Nilai estetik tidak seluruhnya terdiri dari keindahan. Nilai estetis, selain terdiri dari keindahan sebagai nilai yang positif, kini dianggap pula meliputi nilai yang negatif. Hal yang menunjukan nilai negatif itu ialah kejelekan (ugliness). Kejelekan tidaklah berarti kosongnya atau kurangnya ciri-ciri yang membuat suatu benda disebut indah, melainkan menunjuk pada ciri-ciri yang nyata-nyata bertentangan sepenuhnya dengan kualitas yang indah itu (Bahari 2008: 167).

Aspek estetis dalam sebuah karya seni mengenai citra dinamis yakni cerminan kedalaman suatu bentuk tari, ekspresi, serta kreasi yang terdapat dalam suatu karya seni. Citra dinamis merupakan pandangan mengenai suatu cerminan kedalaman tari dengan melihat tari sebagai sebuah entitas virtual, dianalogikan seperti ketika melihat diri dari pantulan cermin, kenampakan diri yang maya itu sesungguhnya memiliki nilai dibalik objek yang terlihat. Bentuk tari dilihat dari kedalaman konsep, gagasan, rangsang di balik objek tersebut menggunakan konsep citra dinamis. Ekspresi merupakan sesuatu yang tidak dapat disamakan antara satu objek dengan yang lain kecuali antar objek itu benar-benar sama, 
ekspresi ini lah yang memberikan ,jiwa" sehingga tarian itu memiliki „isie“ Sedangkan kreasi, karya seni bukan hanya sekedar ilusi meskipun itu merupakan entitas virtual yang hampir nyata, namun karya seni merupakan suatu entitas konkrit dan unik (Widaryanto 2006: 150-155).

Menurut Kutha Ratna (2007: 120-121) nilai bersifat parasit sebab tidak dapat hidup tanpa didukung oleh objek yang diberinya nilai yang disebut sebagai objek estetis. Oleh karena itu, nilai tidak terbatas, nilai melebihi benda yang diberikan nilai sebab nilai dihasilkan melalui antar hubungan. Pemahaman inilah yang disebut sebagai pengalaman estetis, yaitu kemampuan untuk menyediakan diri, bahkan tunduk terhadap mekanisme estetis sebab hanya orang yang bisa diarahkan yang akan menemukan keindahan. Pengalaman estetis yang dimaksud adalah pengalaman yang dilakukan dengan sengaja, bukan pengalaman secara kebetulan sebagaimana dialami pada saat mengadakan perjalanan.

Hasil karya seni merupakan ungkapan perasaan yang dibentuk dari unsurunsur yang dipadu menjadi satu kesatuan yang utuh untuk dapat dinikmati secara estetis. Seniman mengkomunikasikan pikiran dan perasaannya dalam bentuk karya seni untuk dinikmati keindahannya oleh penikmat seni. Untuk memahami karya seni masing-masing memiliki kriteria sendiri-sendiri. Nilai-nilai keindahan tari terangkum dalam kemampuan Hasta Sawanda, yaitu: pacak, pancat, ulat, lulut, wiled, luwes, irama, dan gendhing dan wiraga, wirasa, wirama, wirupa (Jazuli 2008: 176-177).

a. Wiraga: gerak tari, kualitas/bobot bisa terwujud karena adanya kemampuan memanfaatkan unsur tenaga dan waktu. 
b. Wirasa: kemampuan untuk menghayati tarian yang dimanifestasikan dalam bentuk ekspresi wajah dan pengaturan emosi diri.

c. Wirama: kemampuan menyelaraskan tarian dengan alunan musik atau gamelan.

d. Wirupa: kemampuan merias wajah sesuai karakter dan penggunaan kostum yang menunjang penampilan pada saat pertunjukan.

Penghayatan estetika memerlukan bukan saja objek, tetapi juga subyek yang mampu menghayati atau mempersepsi karya seni. Dari kedua kutub subyektif dan obyektif inilah penilaian karya seni sepanjang masa dilakukan (Murgiyanto 2002: 37). Ada dua macam keindahan, yaitu keindahan yang bersifat subjektif dan keindahan yang bersifat objektif.

\subsubsection{Keindahan Subjektif}

Keindahan subjektif berasal dari interpretasi dan evaluasi. Penilaian keindahan sebuah karya seni dari cara menangkap, merespon, atau menanggapi keindahan, sehingga pengamat mampu menemukan, merasakan keindahan dan sekurang-kurangnya daya tarik dari karya seni itu sebatas kemampuan diri (Jazuli 2008: 110).

Menurut David Best dalam Sal Murgiyanto (2002: 37-38) Di dalam tari yang sangat penting adalah perasaan spontan. Makna estetik dan kualitas gerak adalah dua hal yang dirasakan baik oleh penari maupun penonton. Keduanya sangat subyektif dan pribadi sifatnya, sehingga sangat kecil bahkan tidak mungkin dibicarakan. Keindahan adalah sebuah kualitas yang memberikan nikmat pada indera atau ingatan. Karenanya, impresi atau kesan yang diperoleh 
adalah milik pribadi bukan orang lain, karena itu kesan tentang sebuah tarian murni subyektif.

Keindahan subyektif memaksakan kriteria seni yang diakrabinya untuk menilai pertunjukan tari yang baru dikenalnya dengan mengagungkan kemampuan dan ketajaman intuisi subyek (pengamat karya seni). Keindahan subyektif menekankan interpretasi dan evaluasi maka dalam penilaian suatu karya lebih dekat dengan deskripsi murni. Dalam pendekatan ini, nilai karya dicari di dalam kualitas estetik formal seperti bentuk, ukuran, dan warna (Murgiyanto 2002: 38).

Rasa nikmat indah timbul karena peran panca-indera yang memiliki kemampuan untuk menangkap rangsangan dari luar dan meneruskannya ke dalam sehingga rangsangan itu diolah menjadi kesan. Kesan ini dilanjutkan lebih jauh ke tempat tertentu dimana perasaan seseorang bisa menikmatinya. Penangkapan kesan dari luar yang menimbulkan nikmat indah terjadi melalui dua dari lima jenis panca indera, yakni melalui mata dan atau telinga. Yang melalui mata disebut kesan visual dan yang melalui telinga kesan akustis atau auditif (Djelantik 1999: 5).

Keindahan subjektif merupakan pengukuran dari kesan yang timbul pada diri sang pengamat sebagai pengalaman menikmati karya seni. Kesan yang diukur adalah hasil dari kegiatan budi sang pengamat, kegiatan faculty tastenya karena itu dalam penelitian seni terjadilah pada sang pengamat dua kegiatan yang terpisah. Hasil dari kegiatan itu sangat tergantung dari kemahiran sang pengamat, bukan saja kemahiran merasakan sifat-sifat estetik yang tergantung dalam karya 
tersebut tetapi juga kemahiran mengukur dirinya sendiri, mengukur reaksi yang timbul dalam pribadinya, disamping kemahirannya hasil kegiatan itu masih dipengaruhi oleh apa yang membentuk kepribadian sang pengamat yakni pendidikan, lingkungan dan pengalaman umumnya, termasuk kebudayaannya maka dengan itu hasil pengamatan tidak bisa terlepas dari kepribadian sang pengamat dalam kata lain, selalu ada hal-hal yang bersifat subjektif ikut serta dalam penilaian (Djelantik 1999: 169).

\subsubsection{Keindahan Objektif}

Keindahan adalah sebuah kualitas yang memberikan perasaan nikmat kepada indera atau ingatan seseorang. Seseorang mengatakan sebuah benda indah berarti mengenali ciri-ciri atau kualitas pada objek yang diamati yang memberi rasa nikmat (pleasure) kepada diri sendiri atau orang lain yang mampu menghayatinya. Penghayatan keindahan memerlukan adanya "objek" benda atau karya seni yang mengandung kualitas keindahan. Pengalaman menghayati keindahan disebut pengalaman keindahan atau pengalaman estetis (Murgiyanto 2002: 36).

Nilai-nilai estetis adalah sifat-sifat yang mempunyai keindahan sebagai kemampuan yang terdapat pada suatu objek yaitu sebuah karya seni yang dihasilkan seorang seniman sehingga menimbulkan pengalaman estetis pada orang yang mengamatinya sebagai pelaku seni, karena bernilai estetis untuk manusia sebagai subjek indra jiwa (Jazuli 2008: 109). Estetika merupakan cabang ilmu filsafat yang berasal dari pengalaman jiwa yang dapat diserap oleh panca 
indra seseorang karena sublimasi seluruh medium suatu karya seniman secara utuh menempatkan keindahan dan seni sebagai objek telaah (Djelantik 1999: 12).

Keindahan objektif merupakan keindahan yang dapat dilihat dari gaya, bentuk, teknik dan biasanya mengabaikan latar budaya dari mana suatu tari atau penata tari itu berasal. Penilaian keindahan sebuah karya seni secara lebih detail, yaitu unsur-unsur objektif itu yang nyata, dapat dilihat, dapat didengar serta dapat dirasakan (Djelantik 1999: 165).

\subsubsection{Aspek Estetika}

Menurut Djelantik (1999: 17) semua benda atau peristiwa kesenian mengandung tiga aspek mendasar yang termasuk dalam unsur-unsur estetika yakni: wujud, bobot, penampilan.

\subsubsection{Wujud}

Banyak hal dalam kesenian yang tidak nampak dengan mata seperti misalnya suara gamelan, nyanyian, yang tidak mempunyai rupa, tetapi jelas mempunyai wujud. Baik wujud yang nampak dengan mata (visual) maupun wujud yang nampak melalui telinga (akustis) bisa diteliti dengan analisa. Dibahas tentang komponen-komponen yang menyusunnya, serta dari segi susunannya itu sendiri. Wujud dimaksudkan kenyataan yang nampak secara konkrit (berarti dapat dipersepsi dengan matau atau telinga) maupun kenyataan yang tidak nampak secara konkrit, yakni yang abstrak, yang hanya bisa dibayangkan seperti suatu yang diceritakan atau dibaca dalam buku. Pembagian mendasar atas pengertian (konsep) wujud terdiri dari: 


\subsection{Bentuk (Form) atau Unsur Mendasar}

Bentuk adalah kecenderungan kreatif yang dipengaruhi oleh hukumhukum hidup. Bentuk dalam segala kaitannya berarti pengaturan. Bentuk seni mewujud berdasarkan prinsip yang sama dengan yang melandasi wujudnya tingkah laku dan kegiatan hidup manusia (Murgiyanto 1983: 35).

Aspek estetis lahir melalui hubungan bentuk dan isi. Bentuk adalah struktur, isi adalah pesan. Bentuk adalah bagaimana cara menyampaikan sedangkan isi adalah apa yang disampaikan (Kutha Ratna 2007: 442). Bentuk adalah unsur dari semua perwujudan yang dapat diamati dan dirasakan (Langer dalam Jazuli 2008: 57). Bentuk adalah wujud yang dapat dilihat, dengan wujud dimaksudkan kenyataan konkrit di depan kita sedangkan wujud abstrak hanya dapat dibayangkan (Bastomi 1988: 55).

Bentuk adalah organisasi dan kekuatan-kekuatan sebagai hasil struktur internal atau bagian tari (Soedarsono 1999: 45). Bentuk yang dimaksudkan sebagai rupa yang indah menimbulkan kenikmatan artistik melalui penglihatan dan pendengaran. Bentuk indah dicapai karena keseimbangan struktur artistik, keseluruhannya dan berikarsasi misalnya dalam seni tari (Shaidily 1986: 448).

\subsection{Bentuk Tari}

Tari merupakan bagian dari kebudayaan yang diekspresikan dalam bentuk seni pertunjukan. Bentuk adalah perpaduan dari beberapa unsur atau komponen yang bersifat fisik, saling mengkait dan terintegrasi dalam suatu kesatuan. Sebagai bentuk seni yang dipertunjukan atau ditonton masyarakat, tari dapat dipahami sebagai bentuk yang memiliki unsur-unsur atau komponen-komponen dasar yang 
secara visual dapat ditangkap dengan indera manusia. Secara visual komponenkomponen dasar dalam tari memiliki nilai-nilai artistik yang dapat memikat penonton untuk menghayatinya (Maryono 2012: 24-25).

Tari pada dasarnya adalah tidak sekedar menyajikan bentuk-bentuk komponen yang bersifat semata, namun merupakan aktifitas jiwa yang diekspresikan lewat media sensa supaya dapat menarik, memikat, menyentuh, dan menggugah jiwa manusia. Bentuk tari secara garis besar terdiri dari komponen verbal dan komponen nonverbal. Komponen verbal telah tampak adanya koherensi antaraspek-aspek kebahasaan yang terakumulasi menjadi satu kesatuan saling berkaitan sehingga mencerminkan kesatuan makna yang dapat mengarahkan penghayat terhadap kandungan isi. Komponen verbal dalam pertunjukan tari yang berupa sastra tembang digunakan sebagai media penyampaian isi. Komponen yang bersifat nonverbal merupakan bentuk visual yang bersifat artistik sudah memperlihatkan adanya koherensi antarelemen dan saling berkaitan untuk menyampaikan isi supaya dapat diterima penghayat menjadi lebih mantap (Maryono 2012: 25-26).

Kehadiran bentuk tari akan tampak pada desain gerak dan pola kesinambungan gerak yang berlangsung dalam ruang dan waktu. Bentuk tari terlihat dari keseluruhan penyajian tari, yang mencakup paduan antara elemen tari (gerak, ruang, waktu) maupun berbagai unsur pendukung penyajian tari (iringan, tema, tata busana, rias, tempat dan tata cahaya) (Jazuli 2008: 8).

Tari diciptakan dengan tujuan untuk dikomunikasikan kepada para penikmat oleh karena itu, tari tidak hanya sekedar rangkaian gerak, tetapi 
mempunyai bentuk, wujud, kesatuan, dan ciri khas. Bentuk merupakan bagian koreografi yang paling sulit dikerjakan karena di dalamnya banyak sekali terdapat hal-hal yang harus dipertimbangkan. Bentuk dapat dikatakan sebagai organisasi dari kekuatan-kekuatan sebagai hasil dari struktur internal dari tari. Menurut Harold Rugg, bentuk adalah organisasi yang paling cocok dari kekuatan-kekuatan, dari hubungan-hubungan yang dirasakan oleh seniman, hingga dapat meletakkannya dengan sesuatu materi objektif. Bentuk memberi satu keteraturan dan keutuhan dari tari. Struktur internal hubungan dari kekuatan-kekuatan di dalam tari yang menciptakan suatu nilai yang hidup (Widyastutieningrum 2014: 68-70).

\subsection{Bentuk Pertunjukan}

Bentuk pertunjukan dalam tari adalah segala sesuatu yang dipertunjukan atau ditampilkan dari awal sampai akhir yang dapat dinikmati dan dilihat, didalamnya mengandung unsur-unsur nilai keindahan yang disampaikan oleh pencipta kepada penikmat. Kehadiran bentuk tari akan tampak pada desain gerak, pola keseimbangan gerak yang mencakup paduan antara elemen tari (gerak, ruang, waktu) yang ditunjang dengan unsur-unsur pendukung penampilan tarinya (iringan, tema, tata busana, rias, tempat dan tata cahaya) serta kesesuaian dengan maksud dan tujuan tarinya. (Jazuli 2008: 8).

Menurut Indriyanto (dalam Fitri 2016: 11) yang dimaksud bentuk adalah bentuk fisik, bentuk yang diamati sebagai sarana untuk menuangkan nilai yang diungkapkan seorang seniman, sedangkan isi adalah bentuk ungkap, yaitu nilainilai atau pengalaman jiwa yang wigati, yang digarap dan diungkapkan seniman 
melalui bentuk ungkapannya dan yang dapat ditangkap atau dirasakan dalam bentuk fisik. Bentuk ungkapan suatu karya seni pada hakekatnya bersifat fisik, seperti garis, warna, bunyi-bunyian, gerak tubuh dan kata-kata. Bentuk fisik dalam tari dapat dilihat melalui elemen-elemen bentuk penyajian yaitu bentuk penataan tari secara keseluruhan, jadi yang perlu di tekankan dalam kajian bentuk adalah elemen-elemenya.

Bentuk pertunjukkan dalam tari adalah segala sesuatu yang disajikan atau ditampilkan dari awal sampai akhir yang dapat dinikmati dan dilihat, didalamnya mengandung unsur-unsur nilai keindahan yang disampaikan oleh pencipta kepada penikmat. Kehadiran bentuk tari akan tampak pada desain gerak, pola keseimbangan gerak, yang ditunjang dengan unsur-unsur pendukung penampilan tarinya serta kesesuaian dengan maksud dan tujuan tarinya (Jazuli 2008: 4).

Menurut Sedyawati (1981: 90) seni pertunjukkan dikategorikan dalam dua perbedaan, yaitu untuk mendapatkan suatu penyajian seni pertunjukkan sebagai suatu pengalaman bersama. Hal ini berarti seni pertunjukkan adalah suatu pementasan yang ditonton secara khusus, sehingga diantara penonton dan penari ada jarak yang memisahkan. Namun dilihat dari sisi lain dalam suatu pementasan seni pertunjukkan terkandung suatu hubungan antara pemain yaitu keduanya memperoleh pengalaman dan kepuasan.

Bentuk dalam tari merupakan wujud keseluruhan dari sistem, kompleksitas berbagai unsur-unsurnya yang membentuk suatu jalinan atau kesatuan, saling terkait secara utuh, sehingga mampu memberikan daya apresiasi (Maryono 2011: 90). Aspek estetis lahir melalui hubungan bentuk dan isi. Bentuk 
adalah struktur, isi adalah pesan. Bentuk adalah bagaimana cara menyampaikan sedangkan isi adalah a pa yang disampaikan (Kutha Ratna 2007: 442). Struktur adalah sisi elastis pola, kedudukannya antara berubah dan tidak berubah. Berubah oleh susunan struktualnya, tidak berubah karena setia pada pola dasarnya (Sumardjo 2006: 22).

Dalam proses analisis estetika tari unsur minimal yang sering berperan dalam karya seni tari sebagai berikut: pertama, kesatuan (unity) artinya karya tari tersusun secara baik dan relatif sempurna bentuknya; kedua, kerumitan (complexity) tidak sederhana sekali tetapi kaya dengan isi dan unsur yang berbeda dan kadang berlawanan; ketiga, kesungguhan (intensity) terkait dengan kualitas tertentu (gerak, kostum, dan unsur pendukung yang lainnya) yang menonjol; keempat, penonjolan/penekanan (dominance) yakni mengarah pada bagian tertentu sehingga mampu menarik perhatian orang yang menikmati sebagai sesuatu yang penting, menarik, dan mempesona (Indriyanto dalam Arimbi 2016: 8-9).

Menurut Widyastutieningrum (2014: 70-71) ciri-ciri khas dari bentuk yaitu:

1) Kesatuan (unity)

Atribut yang paling esensial dari tari yang diberi bentuk adalah kesatuan atau unity atau keutuhan (wholeness). Tari merupakan kesatuan yang siap dihayati dan dimengerti karena kesatuan itu menarik dan menahan perhatian. Kesatuan menolong pengamat menangkap ide-ide sentral dan memberinya sesuatu yang kepadanya dapat memegang dan menahan di dalam ingatannya. 
2) Variasi (Variety)

Variasi di dalam tari yang merupakan kesatuan harus ada variasi. Kontraskontras dalam ketegangan atau kekuatan-kekuatan meninggikan persepsi dari pola kekuatan-kekuatan dan maka dari itu menyumbang pada keekspresifan tari. Variasi bukanlah untuk kepentingan variasi itu sendiri, variasi harus dikembangkan dalam kerangka yang bersatu.

3) Kontinuitas

Pengulangan adalah unsur yang penting dalam semua seni, demikian pula dalam tari. Sifat sementara dari gerak pengulangan yang digunakan dalam tari bukan hanya sebagai satu cara untuk memberitakan ide, tetapi juga merupakan satu metode untuk meyakinkan pengamat dan memberi kesempatan mencerna dan menyerap gerak.

4) Klimaks

Urut-urutan gerak harus membentuk satu klimaks. Dalam struktur tari ada permulaan, perkembangan, dan penyelesaian. Klimaks dinikmati sebagai titimpuncak dalam perkembangan. Klimaks memberi satu arti dari kehadiran dan penyelesaian.

5) Keutuhan-keutuhan harmonis dan dinamis

Koreografer berusaha mencipta sebuah tari yang diartikan sebagai satu keutuhan harmonis dan dinamis. Ia harus mempunyai permainan dari kekuatankekuatan yang kontras dan berinteraksi yang memberi karya itu vitalitas, tetapi aksi ini harus terjadi dalam satu struktur yang bersatu. 


\subsection{Susunan atau Struktur (Structure)}

Struktur adalah sisi elastis pola, kedudukannya antara berubah dan tidak berubah. Berubah oleh susunan struktualnya, tidak berubah karena setia pada pola dasarnya (Sumardjo 2006: 22). Struktur atau susunan dimaksudkan cara-cara bagaimana unsur-unsur dasar dari masing-masing kesenian telah tersusun hingga berwujud. Cara menyusunnya beraneka macam. Penyusunan itu meliputi juga pengaturan yang khas, sehingga terjalin hubungan-hubungan yang berarti di antara bagian-bagian dari keseluruhan perwujudan itu. Struktur yaitu susunan dari unsur atau aspek (bahan/material baku dan aspek pendukung) sehingga mewujudkan suatu bentuk (Jazuli 2008: 7).

Susunan atau struktur dari suatu karya seni adalah aspek yang menyangkut keseluruhan dari karya itu dan meliputi juga peranan masing-masing bagian dalam keseluruhan itu. Kata struktur mengandung pengertian bahwa di dalam karya seni itu terdapat suatu pengorganisasian, penataan, ada hubungan tertentu antara bagian-bagian yang tersusun itu, akan tetapi dengan adanya suatu penyusunan atau hubungan yang teratur antara bagian-bagian, belumlah terjamin bahwa apa yang terwujud sebagai keseluruhan itu merupakan sesuatu yang indah, yang seni.

Menurut Djelantik (1999: 42-45) tiga unsur estetik mendasar dalam struktur setiap karya seni adalah :

a. Keutuhan atau kebersatuan (Unity)

Keutuhan dimaksudkan bahwa karya yang indah menunjukan dalam keseluruhannya sifat yang utuh, yang tidak ada cacatnya, berarti tidak ada 
yang kurang dan tidak ada yang berlebihan. Keutuhan dapat dilihat dalam keanekaragaman, tujuan dan perpaduan.

b. Penonjolan atau penekanan (Dominance)

Penonjolan mempunyai maksud mengarahkan perhatian orang yang menikmati suatu karya seni sesuatu hal tertentu, yang dipandang lebih penting dari pada hal-hal yang lain. Untuk seni tari penonjolan terdapat pada motif gerak, volume gerak, dinamika gerak dan musik iringan.

c. Keseimbangan (balance)

Rasa keseimbangan dalam karya seni paling mudah tercapai dengan simetri. Keseimbangan dengan simetri memberi ketenangan dan kestabilan yang disebut symmethicbalance. Keseimbangan dapat juga dicapai tanpa simetri, yang disebut a-symmethic balance, yaitu dengan memberi pemberat pada bagian yang terasa ringan, atau mengurangi bobot pada bagian yang berat.

Sebuah tarian dapat menyentuh batin atau perasaan pengamatannya apabila komponen pertunjukan tari yang mendukungnya dibentuk sedemikian rupa sehingga menjadi sebuah tarian yang berjiwa dan menarik perhatian. Dalam seni pertunjukan terdapat komponen pertunjukan tari meliputi: pelaku, gerak, suara atau musik, dan rupa. Rupa dalam hal ini termasuk tata rias, tata pentas, tata busana dan properti.

\subsubsection{Elemen Bentuk Pertunjukan}

Menurut Maryono (2012: 52) wujud komponen-komponen nonverbal dalam tari merupakan bentuk yang secara visual dapat ditangkap dengan indera manusia, bentuk yang memiliki nilai-nilai artistik yang berpotensi memberikan 
kepuasaan estetis bagi penghayat. Unsur-unsur tari yang berbentuk nonkebahasaan terdiri dari: 1) tema, 2) alur cerita atau alur dramatik, 3) gerak, 4) penari, 5) pola lantai, 6) ekspresi wajah/polatan, 7) rias, 8) busana, 9) musik, 10) panggung, 11) properti, 12) pencahayaan, dan 13) setting.

\subsubsection{Tema}

Tema adalah pokok pikiran, gagasan utama atau ide dasar. Tema lahir dari pengalaman hidup seorang seniman tari yang telah diteliti dan dipertimbangkan agar bisa dituangkan ke dalam gerakan-gerakan (Jazuli 2008: 18-19). Tema dalam tari merupakan rujukan cerita yang dapat menghantarkan seseorang pada pemahaman esensi. Tema dapat ditarik dari sebuah peristiwa atau cerita, yang selanjutnya dijabarkan menjadi alur cerita sebagai kerangka sebuah garapan (Maryono 2010: 53).

Tema dalam tari merupakan makna inti yang diekspresikan lewat problematika figur atau tokoh yang didukung peran-peran yang berkompeten dalam sebuah pertunjukan. Prinsip dasarnya tema dalam tari berorientasi pada nilai-nilai kehidupan yang spiritnya memiliki sifat keteladanan sehingga keberadaannya menjadi sangat berharga dan bermakna bagi kehidupan manusia (Maryono 2012: 52).

\subsubsection{Alur cerita/alur dramatik}

Alur cerita atau alur dramatik dalam sebuah karya tari dapat dibentuk dari cerita dan ritme. Bentuk alur cerita atau alur dramatik dalam karya tari yang dibentuk dari cerita, terdapat pada: dramatari/sendratari, frahmen, pethilan, wireng, dan tarian tunggal. Alur cerita atau alur dramatik dalam karya tari yang 
dibentuk dari ritme, dapat dicermati pada jenis-jenis tari rakyat yang tidak menggunakan pola cerita. Artinya bentuk garap tari yang demikian lebih didasarkan pada penggarapan irama atau tempo gerak yang meliputi: keras-lirih, cepat-lambat, kuat-lemah yang didukung permainan ritme musik iringannya (Maryono 2012: 53).

Jenis-jenis garapan tari pada kenyataan dalam sajiannya dari awal hingga akhir terdapat anti klimak-anti klimak yang dibangun untuk pencapaian klimak utama. Jenis-jenis anti klimak atau letupan-letupan yang terdapat dalam garapan sebuah tarian pada dasarnya berjenjang semakin meningkat eskalasi kekuatan ekspresinya. Bobot atau kualitas ekspresi rasa masing-masing tahap atau fase anti klimak semakin mendekati klimak utama sebagai puncak garapan atau puncak dramatik semakin meningkat pada garap tari dengan alur cerita maupun yang tidak menggunakan alur cerita (Maryono 2012: 53).

Jenis-jenis tari yang tidak menggunakan pola cerita, alur dramatik yang dibangun berdasarkan permainan ritme membentuk anti klimak-anti klimak pada masing-masing tahapan bersifat sejajar. Kekuatan dan kualitas ekspresi pada masing-masing tahapan anti klimak tidak menunjukan peningkatan sehingga terkesan monoton. Bentuk garapan tari semacam ini tidak terdapat klimak utama sebagai puncak garapan. Pola-pola garapan ini banyak terdapat pada tari rakyat dan tari primitif (Maryono 2012: 54).

\subsubsection{Gerak}

Menurut Suwandi (2007: 94) mengatakan bahwa gerak adalah serangkaian perpindahan atau perubahan dari angota tubuh yang dapat 
dinikmati. Medium gerak adalah pengalaman fisik yang pokok dari manusia, dimana manusia selalu bergerak. Gerak adalah pertanda kehidupan. Reaksi pertama dan terakhir manusia terhadap hidup, situasi dan manusia lainnya dilakukan dalam bentuk gerk. Perasaan puas, kecewa, cinta, takut dan sakit selalu dialami lewat perubahan-perubahan yang halus dari gerakan tubuh kita. Hidup berarti bergerak dan gerak adalah bahan baku tari (Murgiyanto 1983: 20).

Gerak adalah media ungkapan dari seni pertunjukan yang merupakan salah satu diantara pilar penyangga wujud seni pertunjukan yang dapat terlihat sedemikian kuat. Gerak berdampingan dengan suara atau bunyi-bunyian merupakan cara-cara yang dipergunakan untuk mengutarakan berbagai perasaan dan pikiran yang kemudian ditransformasikan melalui abstraksi (pemisahan) dan distorsi (penyimpangan). Gerak berasal dari tubuh yang tidak pernah menyimpang jauh dari pelakunya (Kusmayati 2000: 83).

Gerak adalah materi baku dari seni tari, tetapi gerak-gerak di dalam tari itu bukanlah gerak yang realistis melainkan gerak yang telah diberi bentuk ekspresif. Susanne K. Langer dalam bukunya Problem of Arts bentuk ekspresif itu ialah bentuk yang diungkapkan manusia untuk dinikmati dengan rasa. Gerakgerak eskpresif ialah gerak-gerak yang indah, yang bisa menggetarkan perasaan manusia. Adapun gerak yang indah adalah gerak yang distilir yang di dalamnya mengandung ritme tertentu. Kata indah di dalam dunia seni identik dengan bagus yang oleh John Martin diterangkan sebagai sesuatu yang memberi kepuasan batin manusia. Jadi bukan hanya gerak-gerak yang halus saja yang bisa indah tetapi 
gerak-gerak yang keras, kasar, kuat, penuh dengan tekanan-tekanan serta gerak aneh pun dapat merupakan gerak yang indah (Soedarsono 1986: 16).

Tari terdiri dari berbagai macam gerak yang dapat mengungkapkan batin manusia. Tari adalah gerak-gerak dari seluruh anggota tubuh atau badan yang selaras dengan musik (gamelan), diatur dengan irama yang sesuai dengan maksud dan tujuan tari. Tari tidak hanya gerak tubuh yang indah dan berirama saja, tetapi juga harus disertai ekspresi jiwa penari, karena sebuah tarian akan jelas maksud dan isinya dengan melihat ekspresi penari dengan dukungan irama (Soedarsono 1986: 4)

Menurut Rusliani (dalam Fitri 2016: 17) gerak dalam seni tari merupakan gerak-gerak yang telah mendapat pengolahan tertentu berdasarkan perasaan khayalan, persepsi, interpretasi atau gerak-gerak yang merupakan hasil dari perpaduan pengalaman estetis dan intelektualitasnya. Didalam gerak terkandung tenaga atau energi yang mencangkup ruang dan waktu, artinya gejala yang menimbulkan gerak adalah tenaga, dan bergerak berarti memerlukan ruang dan membutuhkan waktu.

Gerak tari adalah gerak yang berasal dari hasil proses pengolahan yang telah mengalami stilasi (digayakan), distorsi (pengubahan). Hasil dari pengolahan itu adalah gerak maknawi dan murni. Gerak murni adalah gerak yang digarap sekedar untuk mendapatkan bentuk yang artistik dan tidak dimaksudkan untuk menggambarkan sesuatu. Sedangkan gerak maknawi (gesture) adalah gerak yang mengandung arti yang jelas misalnya gerak nuding atau menunjuk pada tari Bali yang berarti marah, menirukan berhias diri, memanen, mencangkul, namun gerak- 
gerak ini baru bernilai sebagai gerak tari apabila telah mengalami stilasi atau distorsi. Dalam setiap garapan tari diperlukan gerak murni dan gerak maknawi, namun apabila garapan tersebut dipenuhi oleh gerak-gerak maknawi maka garapan itu akan mengarah pada bentuk pantomim(Jazuli 2008: 8-9) .

Makna gerak dalam tari terletak pada penjiwaan, yaitu suatu daya yang mengakibatkan gerakan tampak hidup (Jazuli 2008: 9). Di dalam semua gerak, terdapat faktor ekspresi, karena dilakukan dalam rangka menyatakan atau mendukung pengungkapan rasa, keinginan dan pikiran (Widyastutieningrum 2014: 36).

Elemen dasar tari adalah gerak. Gerak sebagai unsur pokok dalam tari meliputi gerak bagian-bagian tubuh, yakni (1) gerak kepala, (2) gerak badan, (3) gerak tangan, dan (4) gerak kaki. Gerak terjadi karena adanya perpaduan antara fungsi-fungsi tubuh, seperti perpaduan fungsi otak yang memerintahkan syaraf motorik untuk menggerakan otot-otot mata, jari, tangan ataupun kepala dan kaki. Bagian-bagian tubuh manusia yang disebutkan diatas masih merupakan pembagian secara garis besar, sebab masing-masing bagian masih mempunyai bagian-bagian yang lebih spesifik lagi, misalnya kaki masih terdiri atas tungkai atas, tungkai bawah, kaki, serta jari-jarinya. Badan terdiri atas badan bagian bawah yang menyangkut cethik atau panggul, kemudian badan bagian atas adalah lambung. Tangan juga terdiri dari lengan atas, lengan bawah, tangan dan jari-jari. Sedangkan kepala meliputi leher, kepala, muka, dan pandangan mata (Rahmawati 2014:18). 
La Meri dalam Soedarsono (1986: 38) menyatakan bahwa badan manusia dapat dibagi menjadi tiga bagian yang masing-masing mempunyai watak yang berbeda. Bagian atas terletak dari dada ke atas, merupakan bagian yang berwatak intelektual dan spiritual. Ungkapan-ungkapan yang bersifat intelektual spiritual akan lebih berhasil apabila dipusatkan pada bagian atas. Bagian tengah terletak antara bahu sampai pinggang, mempunyai watak penuh perasaan. Emosi penari lebih bisa dituangkan melalui bagian tengah ini. Sedangkan bagian bawah terletak antara pinggang sampai lantai, merupakan bagian vital yang penuh daya hidup. Dalam sebuah tarian antara tubuh, gerak dan komponen tari tidak dapat dipisahkan dengan unsur-unsur yang membangunnya, yaitu gerak, tenaga, ruang dan waktu.

Tubuh dalam dunia tari adalah alat pokok untuk menari. Tubuh untuk keperluan tari adalah tubuh yang berdaya dan berjiwa. Tubuh tari tidak sekedar penampakan dari organ-organ tubuh manusia seperti: kepala, badan, lengan, dan tungkai. Tubuh penari menunjukan tubuh yang sehat, bertenaga, kuat, lentur dan peka. Tubuh yang aktif, terlatih, terampil dan cerdas, tanggap bereaksi dan memiliki koordinasi tinggi menunjukan kemampuan intelektual, emosional dan spiritual (Budi 2011: 15).

Kekhasan bentuk tubuh serta watak pribadi seseorang dapat membentuk perasaan geraknya dan dapat mempengaruhi pemilihan-pemilihan gerakanya. Ada gerakan-gerakan yang bagi seseorang membosankan karena sudah sering dilihatnya, sementara gerakan-gerakan lain dirasakannya lebih merangsang. Sebagai seorang penari atau penata tari, kita harus menggunakan tubuh kita, baik 
dalam berekspresi maupun dalam menghayati atau merasakan apa yang terjadi di sekeliling kita. Oleh karena itu, kita harus mengenal kemampuan, kelebihan, dan kekurangan tubuh kita untuk kemudian melatihnya agar jangkauan geraknya dapat lebih luas. Setiap gerakan tubuh itu harus kita latih di dalam sebuah ruangan kemudian berhenti setelah beberapa saat lamanya dilakukan. Latihannya dilakukan dengan menggunakan tingkatan tenaga tertentu (Murgiyanto 1983: 22).

Pelatihan untuk penari dilakukan secara rutin dan terarah dalam program yang disebut Injeksi. Prinsipnya adalah memberi "suntikan" rutin untuk menghasilkan tubuh-tubuh penari yang "sehat": berdaya dan berjiwa. Gerak injeksi diawali dengan gerakan onclang dilanjutkan dengan tayungan (lumaksono, jengkeng kodok, ayunan, srisik, mecut, tai garing). Injeksi lebih ditekankan pada latihan-latihan tungkai terdiri atas, bawah dan kaki. Pemahaman atas anatomi tubuh mengenai bentuk, struktur dan pemanfaatan sangatlah penting, karena menari pada hakikatnya merupakan perwujudan dari mekanisme gerak-gerak tubuh yang terkoordinasi. Gerak tubuh berkoordinasi dengan hal yang berhubungan dengan intelektual, emosi dan spiritual. Tubuh dapat diperlakukan secara cerdas untuk menyampaikan pesan-pesan komunikatif dan atau simbolik (Budi 2011: 16).

\subsection{Nilai Keindahan Gerak}

Menurut Sal Murgiyanto (1983: 20) mengatakan bahwa aspek dasar gerak adalah tenaga, ruang, dan waktu. Nilai keindahan gerak dapat dilihat dari aspek dasar gerak yang meliputi tenaga, ruang, dan waktu. 


\subsection{Tenaga}

Dalam melakukan gerak dibutuhkan tenaga. Komponen tenaga dalam mewujudkan sebuah gerak tari menjadi sangat penting artinya untuk memunculkan karakter atau penjiwaan seseorang yang sedang menari. Tenaga dalam tari dapat diatur oleh penari untuk memunculkan watak dan dinamik. Keras lembutnya gerak yang muncul, adalah hasil dari pengaturan tenaga yang dapat disalurkan melalui ekspresi gerak. Jika rasa tenaga ini dihayati benar-benar mudah menular kepada penonton sehingga mereka seakan-akan ikut merasakan apa yang dirasakan oleh penari, walaupun sekedar ketegangan pada otot-ototnya. Dalam tari, rasa ini dikenal dengan "simpati otot". Tenaga yang tersalur dalam tubuh penari dapat merangsang ketegangan atau kekendoran di dalam otot-otot penontonnya. Pada waktu menyaksikan penari melakukan gerakan-gerakan sulit, penonton akan merasakan ketegangan pada ototnya, setelah gerakan sulit itu selesai dilakukan, lepaslah ketegangan pada otot mereka. Penggunaan tenaga dalam gerak tari meliputi: intensitas, aksen, dan kualitas (Murgiyanto 1983: 27). a. Intensitas

Intensitas adalah banyak sedikitnya tenaga yang digunakan di dalam sebuah gerak. Dalam bergerak, seorang penari dapat menggunakan tenaga yang jumlahnya sedikit atau banyak. Ada bermacam-macam tingkatan penggunaan tenaga ini, yaitu mulai dari ketegangan yang tidak terlihat sampai pada luapan tenaga yang maksimum. Gerak dengan intensitas tenaga yang besar memberikan kesan penampilan tari yang bersemangat dan kuat. Sebaliknya, penggunaan tenaga yang kecil mengurangi rasa kegairahan dan keyakinan pada tarian. 
Penggunaan tenaga yang mengalun akan memberikan kesan lebih feminim dan lemah lembut. Keindahan suatu tarian akan nampak apabila penari melakukan gerak secara maksimal dengan intensitas yang tepat atau banyak sedikitnya tenaga yang digunakan sesuai dengan gerak tari yang dilakukan sehingga akan menambah nilai keindahan gerak yang dilakukan.

b. Tekanan/aksen

Tekanan atau aksen terjadi jika ada penggunaan tenaga yang tidak rata, artinya ada yang sedikit dan ada pula yang banyak. Penggunaan tenaga yang lebih besar sering dilakukan untuk mencapai kontras dengan gerakan sebelumnya dan tekanan gerak semacam ini berguna untuk membedakan pola gerak yang satu dengan pola gerak lainnya.

Penggunaan tenaga yang teratur menimbulkan rasa keseimbangan dan rasa aman, sedangkan penggunaan tenaga yang tidak teratur tekanannya menciptakan suasana yang mengganggu bahkan membingungkan (Murgiyanto 1983: 27-28).

Gerak dengan tekanan tenaga yang tinggi akan memberikan kesan tarian yang kuat dan gagah sedangkan gerak dengan intensitas tenaga yang lemah maka akan menimbulkan kesan tari yang lembut dan halus. Gerak tanpa tekanan berarti tenaganya merata sehingga menimbulkan kesan tari yang lemah lembut dan penggunaan aksen atau tekanan yang tepat untuk gerak-gerak tertentu dalam tari akan menambah nilai estetis dari gerak tari yang dibawakan.

c. Kualitas

Kualitas merupakan cara menyatukan gerak sesuai dengan desain yang dikehendaki (Jazuli 2008: 104). Kualitas-kualitas gerak tertentu menimbulkan 
rasa-rasa gerak tertentu. Kualitas-kualitas gerak dapat dibedakan antara lain yang bersifat ringan atau berat, lepas atau berbatas jelas serba menghentak cepat, langsung atau tidak langsung dalam menuju titik akhir dari frase gerak. Ketiga elemen gerak (tenaga) ruang dan waktu tidak pernah terpisah dalam gerak tubuh. Ketiganya terangkai secara khas sebagai penentu "kualitas gerak". Kita dapat berjalan perlahan-lahan (waktu), dengan langkah lebar (ruang), dan santai (tenaga). Dari kombinasi cara menggunakan ruang, waktu dan tenaga bisa mengenal kualitas-kualitas gerak seperti mengenyun, bergetar, mengamban, dan memukul. Kita harus memahami masalah penggunaan tenaga, bagaimana melakukannya dan kapan mempergunakannya. Cara penggunaan tenagalah yang memberikan efek dinamik dalam sebuah tarian (Murgiyanto 1983: 28).

Kekuatan seperti ini sulit didefinisikan, sebab meliputi motivasi untuk bergerak, semangat yang menyala-nyala serta pancaran batin yang membuat sebuah tarian menjadi hidup. Kekuatan itu dikenali lewat kemampuan seorang penari untuk menghadirkan dirinya secara nyata di atas pentas, artinya hadir utuh secara jasmaniah dan mental setiap saat di atas pentas, misalnya terlihat dari nyala pandangan mata seorang penari. Seorang penari harus berusaha menemukan kekuatan batiniah ini pada dirinya msing-masing dengan jalan melatih mempertajam kesadaran batiniah serta kepekaan penghayatannya terhadap alam lingkungannya.

Kualitas seorang penari hanya akan tercapai bila penari mampu menghayati dan mengekspresikan sesuai dengan perannya secara totalitas jiwa. Ketajaman dan kepekaan rasa yang dimiliki penari dapat teraktualisasi dalam 
sebuah sajian tari dan mampu menggugah intuisi para penghayat. Keluluhan jiwa seorang penari dalam menyajikan karakter tari merupakan puncak prestasinya bagi seorang seniman. Jika penari tidak berkualitas kekuatan ekspresinya akan tampak lemah. Kelemahan dari kualitas penari sebagai penyampai isi atau pesan dari seniman penyusun tari merupakan kendala yang sangat vital karena hanya dari ekspresi penari makna tari dapat ditangkap atau dihayati oleh penonton (Parker dalam Maryono 2008: 57).

\subsection{Ruang}

Ruang adalah sesuatu yang tidak bergerak dan diam sampai gerakan yang terjadi di dalamnya mengintrodusir waktu, dan dengan cara demikian mewujudkan ruang sebagai suatu bentuk, suatu ekspresi khusus yang berhubungan dengan waktu yang dinamis dari gerakan (Hadi 1996: 13).

Pengertian ruang atau arena adalah lantai tiga dimensi yang di dalamnya seorang penari dapat mencipta suatu imaji dinamis, yaitu perincian bagian-bagian komponen yang membawa banyak kemungkinan untuk mengeksplore gerak. Seorang penari dengan ketrampilan geraknya dapat membuat ilusi-ilusi, sehingga ruang menjadi fleksibel dan luar biasa keberadaannya. Aspek-aspek ruang karena gerakan tubuh akan terlihat oleh penonton secara keseluruhan, sehingga aspek ruang merupakan komponen visual tari yang kuat. Analisis bentuk ruang selalu hadir dalam gerakan tari, seperti misalnya menghentikan seorang penari yang sedang bergerak, maka dapat mewujudkan suatu desain bentuk atau wujud dalam ruang seperti sebuah sikap atau pause yang mungkin menjadi tidak berdaya karena menahan keseimbangan gerakan (Hadi 2007: 54-55). 
Kesadaran dan kepekaan rasa ruang ini harus kita manfaatkan di dalam menyusun sebuah tarian sebab pada waktu bergerak kita selalu menggunakan ruang. Hal itu juga harus menjadi pertimbangan dalam menggunakan ruang pentas. Figur penari yang bergerak menciptakan desain di dalam ruang dan hubungan timbal balik antara gerak dan ruang akan membangkitkan corak dan makna tertentu. Seorang penari yang mampu mengontrol penggunaan ruang akan memperbesar kekuatan yang ditumbuhkan oleh gerak yang dilakukannya. Hal itu disebabkan oleh gerak penari berinteraksi dengan ruang (Murgiyanto 1983: 23).

Ruang merupakan unsur pokok lain yang menentukan terwujudnya suatu gerak, tanpa ada ruang tidak mungkin terwujud suatu gerak. Setiap gerak yang dibuat memiliki desain-desain ruangan dan berhubungan dengan benda-benda lain dalam dimensi ruang dan waktu, dengan demikian penari semata-mata dapat bergerak atau menari karena adanya ruang. Ruang dalam tari dapat dibedakan menjadi dua, yaitu:

a) Ruang Yang Diciptakan Oleh Penari

Ruang yang diciptakan oleh penari adalah ruang yang langsung berhubungan dengan penari, batas ruang yang diperlukan untuk melakukan gerak sesuai dengan gerakan yang mampu dilakukan oleh penari, yaitu batas yang paling jauh yang dapat dijangkau oleh tangan dan kaki penari dalam posisi tidak pindah tempat.

b) Ruang Pentas

Ruang ini tempat penari melakukan gerak dalam wujud ruang secara nyata. Ruangan ini merupakan arena yang dilalui penari dalam melakukan gerak. 
Desain ruang mempermasalahkan bagaimana merencanakan penataan dan pemaduan unsur-unsur ke ruangan agar dapat menghasilkan bentuk ruangan yang estetis. Dalam hubungannya dengan komposisi, beberapa elemen ruang yang patut mendapatkan perhatian adalah: garis, volume, arah, level, fokus pandangan (Sedyawati 1986: 24).

1) Garis

Garis yang dimaksudkan berupa kesan yang ditimbulkan dari gerak tubuh penari ketika menari. Gerak tubuh dapat diatur sedemikian rupa sehingga memberikan kesan berbagai macam garis. Garis-garis ini menimbulkan kesan yang tidak berbeda dengan garis-garis dalam seni rupa. Garis mendatar memberikan kesan istirahat. Garis tegak lurus memberikan kesan tenang, dan seimbang. Gerak tubuh yang melengkung menimbulkan garis lengkung yang memberikan kesan lentur tidak kaku sedangkan garis-garis diagonal atau zigzag memberi kesan dinamis (Murgiyanto 1983: 23).

Secara garis besar gerak tari dapat dibagi dua, yaitu simetris dan asimetris. Garis-garis simetris mempunyai watak yang sederhana, kokoh, tenang, tetapi kalau terlalu banyak digunakan akan menjadi membosankan. Sedangkan garisgaris asimetris mempunyai watak kurang kokoh tetapi dinamis dan menarik. Seorang koreografer disarankan untuk banyak menggunakan garis-garis asimetris agar garapannya tetap menarik (Doris Humprey dalam Soedarsono 1986: 39).

2) Volume

Volume merupakan jangkauan gerak yang dibuat oleh penari yang tergantung besar kecilnya ruang pentas. Misalnya karena ruang pentas tidak 
terlalu luas, maka langkah penari yang lebar dibuat menjadi langkah-langkah pendek dengan jumlah yang sama. Volume gerak tari dibedakan menjadi tiga, yaitu: volume besar atau terbuka mempunyai watak kelaki-lakian, volume kecil atau tertutup mempunyai watak kewanitaan, dan volume sedang memberikan kesan kelaki-lakian yang halus atau kewanitaan yang agak kelelakian/banci (Soedarsono 1986: 39).

Gerakan tubuh kita mempunyai ukuran besar kecil atau volume. Gerakan melangkah ke depan misalnya, bisa dilakukan dengan langkah yang pendek, langkah biasa atau langkah lebar. Ketiga gerakan itu sama tetapi ukurannya berbeda. Sebuah posisi atau gerakan yang kecil bisa dikembangkan, sementara gerakan yang besar dapat dikecilkan volumenya (Murgiyanto 1983: 23).

3) Arah

Gerak juga memilik arah. Seringkali dalam tarian mengulang sebuah pola atau rangkaian gerak dengan mengambil arah yang berbeda. Kecuali arah ke atas dan ke bawah, sebuah gerakan dapat dilakukan ke arah depan, belakang, kiri, kanan, serong kanan depan, serong kiri depan, serong kanan belakang dan serong kiri belakang. Hal ini yang masih berhubungan dengan arah dalam tarian adalah arah hadap penari. Arah hadap tubuh seorang penari dapat banyak berbicara untuk mengenali tingkah laku seseorang, misalnya seorang pahlawan akan berjalan lurus ke depan tanpa rasa takut, tetapi seorang pengecut akan berjalan berbelit-belit dan tidak langsung menuju ke tujuannya. Perasaan yang disuguhkan oleh seseorang yang bergerak mundur menjauhi bahaya dapat berbeda-beda, misalnya mundur 
tetap menghadap ke bahaya itu, atau berbalik dan melarikan diri (Murgiyanto 1983: 23-24).

4) Level

Garis mendatar yang dibuat oleh seorang penari dengan kedua belah lengannya yang dapat memiliki ketinggian yang berbeda-beda. Level tinggi adalah daerah tinggi yang terletak pada penari ke atas seperti hal nya mengangkat kedua tumit. Level sedang adalah daerah yang terletak pada ruang antara penari dengan panggung penari seperti hal nya berdiri biasa, jongkok. Level rendah adalah daerah yang terletak antara pinggang penari dengan lantai seperti halnya duduk. Ketinggian maksimal yang dapat dicapai oleh seorang penari adalah ketika ia meloncat ke udara, sedang ketinggian minimal dicapainya ketika rebah ke lantai (Murgiyanto 1983: 24).

5) Fokus Pandangan

Delapan orang penari yang berada di atas pentas dan semuanya memusatkan perhatian ke salah satu sudut pentas, maka perhatian kita pun akan terarah ke sana, sehingga penari yang sesaat kemudian ke luar dari sudut ini akan menjadi fokus pandang kita. Akan tetapi, jika arah pandang tiap-tiap penari berbeda-beda, perhatian kita pun akan terpecah. Andaikata ketujuh orang di antara mereka itu memusatkan perhatiannya kepada orang yang ke delapan, maka fokus perhatian pun akan terarah kepadanya (Murgiyanto 1983: 25).

\subsection{Waktu}

Waktu disebut juga durasi yaitu lamanya sajian di atas pentas. Hitungan waktu dimulai dari awal mulai sampai dengan berakhirnya sajian. Lamanya waktu 
sangat berpengaruh pada lamanya iringan musik. Waktu yang berkaitan dengan tempo (cepat dan lambat) dibuat bervariasi, artinya tempo iringan disesuaikan dengan tempo gerak atau sebaliknya. Tempo meliputi tempo lambat, sedang dan tempo cepat (Made astini dan Usrek Tani Utina 2007: 174).

Unsur waktu juga menentukan dalam membangun gerak tari. Waktu tetap berjalan tanpa terpengaruh oleh apapun yang kita lakukan. Kita bisa bergerak bersamanya atau melawannya. Kita dapat terperangkap dalam kesibukan kerja atau memanfaatkannya untuk jalan-jalan dan beristirahat. Pengalaman tentang waktu dapat dirasakan juga ketika berjalan cepat dan kemudian berjalan mendadak. Jika waktu dihayati dengan sungguh-sungguh dalam menari akan merasakan aspek cepat lambat, kontras, berkesinambungan, dan rasa berlalunya waktu sehingga dapat digunakan secara efektif (Murgiyanto 1983: 25).

Waktu adalah suatu alat untuk memperkuat hubungan-hubungan kekuatan dari rangkaian gerak, dan juga sebagai alat untuk mengembangkan secara kontinyu, serta mengalirkan secara dinamis, sehingga menambah keteraturan tari atau koreografi. Struktur waktu dalam tari dapat dianalisis adanya aspek-aspek tempo, ritme, dan durasi (Hadi 2011: 26).

1) Tempo

Aspek tempo atau irama dalam tari dipahami sebagai suatu "kecepatan" atau "kelambatan" sebuah irama gerakan. Jarak antara "terlalu cepat dari cepat", dan "terlalu lambat dari lambat", akan menentukan energi atau rasa geraknya, sehingga tempo-tempo semacam itu tersedia apabila seorang penari menginginkan dan mampu melakukannya (Hadi 2011: 26-27). 
Tempo atau kecepatan sebuah tarian ditentukan oleh jangka waktu dalam mana dapat diselesaikan serentetan gerakan-gerakan tertentu, jangka waktu sebuah tubuh seorang penari menyelesaikan sebuah rangkaian gerak. Gerakan yang cepat biasanya lebih aktif dan menggairahkan, sedangkan gerakan yang lambat menguasai rangsangan tersebut (Widyastutieningrum 2014: 53). Gerak dengan tempo cepat pada tarian akan memberikan kesan lincah, ramai, dan berenergi. Gerak dengan tempo lambat pada tarian akan memberikan kesan lemah lembut.

2) Ritme

Ritme dalam gerak tari menunjukan ukuran waktu dari setiap perubahan detail gerak. Ritme lebih mengarah kepada ukuran cepat atau lambatnya setiap gerakan yang dapat diselesaikan oleh penari. Ritme terjadi dari serangkaian bunyi yang sama atau tidak sama panjangnya yang sambung-menyambung disusun sedemikian rupa sehingga membentuk pola-pola ritmis tertentu yang menghasilkan perulangan yang teratur dari kumpulan-kumpulan bagian gerak atau suara yang berbeda kecepatannya (Murgiyanto 1983: 26).

Ritme menghendaki adanya pengaturan pola-pola gerak dimana ada serangkaian permukaan-permukaan, perkembangan-perkembangan, dan akhirakhir yang mengarah ke struktur: awal-klimaks-akhir. Struktur ini dapat dibandingkan dengan pengaturan ritme musik. Pola ritme yang hendak ditonjolkan harus ditekankan dan dipisahkan dari dalam wujud yang jelas, serta rangkaian-rangkaian terencana. Setiap transisi dari awal ke bagian tengah dan dari tengah ke bagian akhir harus disusun dahulu (Widyastutieningrum 2014: 53). 
Aspek ritme dipahami dalam suatu gerakan tari sebagai pola hubungan "timbal-balik" dari jarak waktu "cepat" dan "lambat" atau susunan tekanan "kuat dan lemah". Pengulangan yang sederhana dengan interval-interval berjarak waktu yangsama, perubahannya atau pengulangannya akan menimbulkan pengaliran energi yang "ajeg" dan sama. Tekanan atau laku-laku itu mempunyai rasa keteraturan dan sering disebut dengan "ritme ajeg" atau even rhytm. Apabila pengulangan jarak waktunya bervariasi, sehingga intervalnya tidak sama pengulangannya, maka ritme semacam itu "tidak ajeg" atau uneven rhytm. Setiap gerakan mempunyai ritme-ritme semacam itu, sehingga energi yang berjalan dan kadang-kadang berhenti, memberikan wujud penerapan dan pengendoran kekuatan selama durasi waktu dibutuhkan (Hadi 2011: 27).

Ritme bisa disebut juga sebagai isian gerak atau kepadatan gerak dalam satu ketukan tertentu. Isian gerak semakin padat dibanding dengan ketukan maka memberi kesan lincah, ritme tidak datar atau tidak rata sedangkan isian gerak sedikit dibandingkan dengan ketukan maka memberi kesan lemah lembut pada tarian.

3) Durasi

Aspek durasi dipahami sebagai jangka waktu yang digunakan yaitu berapa lama gerakan tari atau koreografi itu berlangsung. Barangkali dengan hitungan detik atau menit, bahkan dapat lebih panjang lagi sebuah gerakan itu dilakukan. Kesadaran terhadap durasi dalam gerakan ini dapat dirasakan, gerakan itu dapat dibuat dengan ritme "ajeg" dan "tidak ajeg", tergantung kebutuhan dan motivasinya, sehingga mempengaruhi kualitas atau rasa gerakannya. Kemudian 
dicoba dengan menggunakan durasi waktu yang lebih pendek atau singkat. Perbedaan durasi itu akan mempengaruhi kualitas gerakan, meskipun gerakannya secara esensial sama (Hadi 2011: 27). Keindahan tari dapat dilihat dari durasi atau lamanya waktu pertunjukan dengan mengefektifkan waktu pertunjukan tari semaksimal mungkin dan disesuaikan dengan tariannya agar penonton mampu menikmati dan menyerap isi tarian.

\subsubsection{Penari}

Penari adalah seorang seniman yang kedudukannya dalam seni pertunjukan tari sebagai penyaji. Kehadiran penari dalam pertunjukan tari merupakan bagian pokok yaitu sebagai sumber ekspresi jiwa dan sekaligus bertindak sebagai media ekspresi atau media penyampai (Maryono 2012: 56).

Pelaku atau seniman adalah penyaji dalam pertunjukan, baik yang terlibat langsung maupun tidak langsung untuk menyajikan bentuk pertunjukan. Beberapa pertunjukan ada yang hanya melibatkan pelaku laki-laki, pelaku perempuan, atau menampilkan pelaku laki-laki dan perempuan. Pelaku pertunjukan dilihat dari usia dapat bervariasi, misalnya anak-anak, remaja, atau orang dewasa (Cahyono 2006: 241).

Menurut Soedarsono (1986: 10) Pelaku ditinjau dari jumlahnya dapat digolongkan menjadi tiga yaitu penari tunggal, berpasangan dan berkelompok. Tunggal artinya suatu tarian yang disajikan oleh satu orang penari saja baik lakilaki maupun perempuan. Berpasangan artinya suatu tarian yang disajikan oleh dua orang penari atau sepasang yaitu sejenis atau berlainan jenis, antara penari satu dengan satunya terdapat keterkaitan yang kuat (respon). Berkelompok 
artinya tarian dengan jumlah penari lebih dari satu orang dan antara penari satu dengan yang lainnya ada keterkaitan (respon).

Penari memiliki fungsi sebagai sumber isi dan merupakan bentuk sebagai penyampai isi. Untuk itu sebagai seorang penari harus mempunyai kemampuan fisik maupun nonfisik yang memadai terjaga kondisi kebugarannya. Kondisi fisik penari harus benar-benar dalam keadaan sehat, segar secara total kondisi jasmani maupun rohani agar sistem ekspresi menjadi berfungsi secara optimal dan sumber ekspresinya menunjukan kualitas dan kuantitas sebagai sumber aliran nilai. Kualitas seorang penari hanya akan tercapai bila penari mampu menghayati dan mengeskpresikan sesuai dengan perannya secara totalitas jiwa. Ketajaman dan kepekaan rasa yang dimiliki penari dapat teraktualisasi dalam sebuah sajian tari dan mampu menggugah intuisi para penghayat (Maryono 2012: 57).

Pelaku seni berperan membantu dalam sebuah pertunjukan. Pelaku seni yaitu penari atau pemusik. Keindahan dari pelaku seni dapat dilihat melalui postur tubuh dan jenis kelamin. Jenis kelamin dan postur tubuh penari harus disesuaikan dengan karakter atau tokohnya, misalnya apakah harus jenis kelamin wanita atau laki-laki, maupun postur tubuh gemuk, kurus, pendek, dan tinggi (Hadi, 2011: 92). Penari wanita memberikan kesan feminim, sedangkan penari laki-laki memberikan kesan maskulin.

\subsubsection{Pola lantai}

Pola lantai atau gawang dalam sajian tari merupakan salah satu unsur yang memberikan konstribusi penting dalam aktualisasi visual. Pola lantai merupakan garis yang dibentuk dari gerak tubuh penari yang terlintas pada lantai 
atau panggung pertunjukan merupakan garis imajiner yang dapat ditangkap dengan kepekaan rasa. Pola lantai menjadi sangat penting agar perpindahan antarpenari maupun perpindahan antarkelompok penari menjadi tertata rapi, jelas, dan memberikan kesan teatrikal yang mantap (Maryono 2012: 58).

Bentuk pola lantai dalam pertunjukan tari pada prinsipnya terdiri dari dua jenis yaitu a) semetris atau seimbang dan b) asemetris. Pola lantai semetris dan asemetris merupakan bentuk pola lantai yang dipengaruhi jumlah penari dan bentuk garis yang dibuat penari (Maryono 2012: 58).

Jenis pola lantai semetris yang dipengaruhi atau didasarkan jumlah penari, misalnya pola lantai bagian kanan empat penari untuk bagian kiri juga empat penari. Jenis pola lantai semetris yang didasarkan pada bentuk garis yang dibuat penari, misalnya pola lantai bagian kanan berbentuk segitiga untuk bagian kiri juga berbentuk segitiga sekalipun jumlah penari tidak sama, namun selisih atau perbedaan jumlah penari tidak signifikan. Bentuk pola lantai asemetris berdasarkan jumlah penari, misalnya panggung bagian kiri tiga penari untuk bagian kanan satu penari. Sedangkan pola lantai asemetris berdasarkan bentuk, misalnya panggung bagian kiri membentuk pola lurus untuk bagian kanan membentuk pola segitiga (Maryono 2012: 58-59). Garis-garis yang dihasilkan dari bentuk pola lantai dapat memberikan kesan tersendiri pada tarian. Garis lurus memiliki kesan kuat dan sederhana, sedangkan garis lengkung memiliki kesan lembut. 


\subsubsection{Ekspresi wajah/polatan}

Ekspresi wajah atau polatan merupakan perubahan kondisi visual raut muka atau wajah seseorang. Ekspresi wajah merupakan sarana untuk mendapatkan pemahaman dan gambaran kondisi psikologis seseorang. Wajah memiliki kemampuan sebagai sarana ekspresi karakter yang bersifat pribadi maupun bersifat penjiwaan terhadap peran tokoh dalam seni pertunjukan (Maryono 2012: 60).

Dalam seni pertunjukan tari ekspresi wajah memiliki kontribusi cukup siknifikan yaitu membangun suasana adegan yang berkolaborasi dengan unsurunsur gerak tangan, kaki, badan, dan kepala. Ekspresi wajah dalam pertunjukan tari digunakan penari mengekspresikan totalitas emosi peran atau tokoh. Berdasarkan ekspresi wajah/polatan penari akan tampak dan tercermin suasana yang sedang dialami peran atau tokoh. Suasana-suasana sedih, gembira, marah, tegang, takut, konflik, dan bahagia merupakan kondisi yang harus dibangun melalui ekspresi wajah seorang penari (Maryono 2012: 60).

\subsubsection{Tata Rias dan Busana (make up)}

Rias merupakan seni memperindah wajah dengan menggunakan alat-alat kosmetik yang dapat mempertegas karakter yang sedang diperankan (Sarastiti, dian dan veronica eni eryanti 2012:4). Karakter peran atau tokoh dalam pertunjukan tari banyak dibentuk dari rias alat-alat kosmetik. Rias dalam seni pertunjukan tidak sekedar untuk mempercantik dan memperindah diri tetapi merupakan kebutuhan ekspresi peran sehingga bentuknya sangat beragam bergantung peran yang dikehendaki. Prinsip dasar merias dalam pertunjukan tari 
adalah untuk mengubah wajah pribadi dengan alat-alat kosmetik yang disesuaikan dengan karakter figur atau peran supaya tampil ekspresif. Kadar perubahan wajah dimaksud sangat relatif artinya bahwa pada setiap rias, masing-masing penari berusaha menampilkan wajah sesuai dengan ekspresi karakter yang dikehendaki. Jenis-jenis alat rias yang digunakan dalam pertunjukan tari diantaranya: rose, bedak dasar, eye shadow, pensil alis, liner, bulu mata, bulu kumis, dan bulu jenggot (Maryono 2012: 61).

Tata rias tari tetap konsisten terhadap kaidah-kaidah yang diperlukan dalam pertunjukan tari, maka perlu diperhatikan prinsip-prinsip penataan rias tari antara lain: (1) Rias hendaknya mencerminkan karakter tokoh/peran, (2) Kerapian dan kebersihan rias perlu diperhatikan, (3) Garis-garis yang dikehendaki jelas, (4) Ketepatan pemakaian desain rias (Jazuli 2008: 25).

Rias panggung (Stage make up) adalah rias yang diciptakan untuk penampilan di atas panggung yang berbeda dengan rias sehari-hari. Tata rias panggung dibedakan menjadi dua, yaitu tata rias panggung (tertutup) dianjurkan agar riasan lebih tegas, jelas garis-garisnya dan tebal, karena penonton melihat pertunjukan dalam jarak yang cukup jauh. Tata rias panggung arena (terbuka), pemakaian rias tidak perlu terlalu tebal, yang lebih utama adalah halus dan rapi karena penonton lebih dekat dengan pertunjukan (Jazuli 2008: 23).

Fungsi rias antara lain untuk mengubah karakter pribadi menjadi karakter tokoh yang sedang dibawakan, untuk memperkuat ekspresi wajah sesuai peran dan untuk menambah daya tarik penampilan karena dengan rias kekurangan dapat tertutupi (Jazuli 2008: 23). Tata rias digunakan penari agar penampilannya di 
atas pentas dapat memenuhi karekter dan identitas yang diinginkan (Suriyanto dalam Sarastiti 2012: 103).

Corson dalam Dini (2015: 20) menyebutkan beberapa kategori rias, yaitu rias korektif (corrective make up), rias karakter (character make up), dan rias fantasi (fantasy make up). Rias korektif adalah rias wajah sehari-hari dengan tujuan membuat wajah menjadi cantik, tampak lebih muda dan lebih tua dari usia sebenarnya dan berubah sesuai dengan yang diharapkan seperti lebih jonjong atau lebih bulat, berfungsi untuk mempertegas garis-garis wajah tanpa mengubah karakter orangnya. Rias karakter yaitu merias wajah agar sesuai dengan karakter yang dikehendaki dalam cerita, seperti: karakter tokoh-tokoh fiktif, legendaris dan historis. Rias fantasi yaitu merias wajah agar berubah sesuai dengan fantasi perias, dapat yang bersifat realistis maupun non realistis, sesuai dengan kreatifitas periasnya (Lestari, 1993: 61-62).

Nilai keindahan rias bisa dilihat dari tata hubungan antara bagian yang dirias dengan warna-warna tertentu. Bagian wajah yang dirias meliputi rias mata, alis, hidung, pipi, bibir dan bagian wajah secara keseluruhan dengan garis-garis rias yang rapi seperti membuat alis dan pemilihan warna yang sesuai sehingga memberikan kesan lebih artistik. Rias pada bagian mata meliputi pemberian warna eye shadow dengan warna-warna cerah seperti merah, kuning emas, biru muda, hijau muda memberi kesan segar dan lebih berani sedangkan warna-warna gelap seperti coklat dan abu-abu akan memberikan kesan lebih natural. Penggunaan alat dan bahan rias wajah (make up) untuk mempertegas daerah tertentu pada wajah penari menjadikannya terlihat cantik maupun berkarakter. 
Make up berfungsi memperjelas wajah, maka garis mata dan alis serta mulut perlu dibuat yang tebal. Tata rias dalam tari digunakan untuk memperjelas garis-garis wajah penari untuk mengekspresikan gerak-gerak tari. Sehingga tarian dapat hidup dan memberikan nilai keindahan.

\subsubsection{Tata Busana atau Kostum}

Tata busana adalah segala sesuatu yang membalut tubuh berfungsi sebagai penegas karakter dan sebagai daya tarik dalam suatau penyajian tari. Tata busana adalah ketrampilan untuk mengubah, melengkapi, membentuk sesuatu yang dipakai mulai dari ujung rambut hingga ujung kaki (Lestari 1993: 16). Busana adalah alat yang dipakai untuk menutupi bagian-bagian tubuh sesuai dengan norma masyarakat yang berlaku. Pemakaian busana dalam tari lebih pada pertimbangan keindahan sesuai dengan kebutuhan tarinya. Fungsi busana dalam tari adalah untuk mendukung tema atau isi tari, dan untuk memperjelas peranperan dalam suatu sajian tari. Busana tari yang baik bukan hanya sekedar untuk menutup tubuh semata, melainkan juga harus dapat mendukung desain ruang pada saat penari sedang menari (Jazuli 2008: 21).

Kostum diartikan sebagai pakaian, pada dasarnya pakaian mempunyai tiga fungsi yaitu untuk kenyamanan, untuk kesopanan, dan untuk pertunjukan (Moriss dalam Pebriyanti 2013: 13). Kostum tari yang baik bukan sekedar berguna sebagai penutup tubuh penari, tetapi merupakan pendukung desain keruangan yang melekat pada tubuh penari (Murgiyono dalam Sarastiti 2012: 18).

Busana selain mempunyai bentuk atau mode juga memiliki warna yang sangat bermakna sebagai simbol-simbol dalam pertunjukan. Jenis-jenis simbolis 
bentuk dan warna busana para penari dimaksudkan mempunyai peranan sebagai: a) identitas peran, b) karakteristik peran, dan c) ekspresi estetis. Warna-warna dasar busana dalam seni pertunjukan mempunyai makna simbolis yang dapat mengarahkan pemahaman karakteristik peran atau figur tokoh. Warna busana hitam dalam pertunjukan tari memiliki kesan bijaksana, berwibawa, dan anggun. Warna putih merupakan warna yang memiliki kesan suci, setia, dan aksentuasi yang berhubungan dengan kehidupan nirwana. Warna merah lebih memberikan kesan berani, agresif, dan dinamis yang banyak diperuntukan tokoh-tokoh. Warna kuning yang sering digunakan dalam pertunjukan tari adalah warna-warna kuning kuning keemasan dan kuning kunyit tua yang memiliki kesan glamor, mewah, keagungan, kejayaan, dan bijaksana. Keragaman bentuk dan warna-warna busana dalam pertunjukan tari merupakan sarana atau media presentasi estetis. Bagi penyusun tari bentuk dan warna-warna busana yang dipakai penari selain berkaitan dengan identitas peran dan karakteristik peran juga tidak kalah penting adalah dapat memberikan pemahaman estetis terhadap penonton (Maryono 2012: 61-64).

Nilai keindahan tata busana dengan rias dapat diwujudkan melalui perpaduan busana yang digunakan dalam suatu sajian tari yang memberikan berbagai macam kesan yang ditimbukan, dengan berbagai warna dan aksesoris penari terlihat lebih hidup didalam pentas. Ekspresi penari dapat ditimbulkan melalui penggunaan busana tari. Seni menata segala pakaian yang dikenakan oleh penari untuk mempertunjukan karya tari memberikan nilai keindahan tersendiri, terkadang busana tari terlihat unik dengan berbagai macam perpaduan warna dan 
bentuk. Warna dalam busana tari disesuaikan dengan tema tari dan dapat memberikan gambaran perasaan atau penjiwaan terhadap tarian. Jadi nilai keindahan busana akan nampak apabila semua tata hubungan terkait. Keragaman bentuk dan warna busana dalam pertunjukan tari merupakan sarana atau media presentasi estetis. Keindahan pemakaian busana akan nampak bila bentuk busana tari sesuai dengan isi sajian tari dengan pemilihan warna yang tepat.

\subsubsection{Iringan Tari (Musik)}

Iringan adalah serangkain nada yang telah dibentuk sedemikian rupa baik dengan alat musik, maupun yang berasal dari tubuh, yang berfungsi sebagai penegas suasana dalam suatu penyajian tari. Tari sebagai desain gerak dalam penyajiannya tidak terlepas dari musik pengiring, karena dalam hal ini tari dan musik berhubungan erat (Hadi 1996: 31). Musik akan selalu memberi tekanan ekspresi suatu gerak, seperti yang dikatakan Sumarsam (2002: 8) musik adalah manifestasi proses pengolahan kedalaman rasa dari penciptanya. Jadi musik adalah partner dari sebuah karya tari yang tak bisa ditinggalkan.

Hubungan musik dan tari sangat erat kaitannya, keduanya berasal dari sumber yang sama yaitu dorongan ritmis manusia. Pada dasarnya musik di bagi menjadi dua yaitu musik internal dan musik eksternal. Musik internal adalah musik yang bersumber dari dalam diri penari itu sendiri, seperti siulan, teriakan, tepuk tangan, hembusan nafas, tiruan bunyi alat musik, hentakan kaki, bunyi kostum atau perlengkapan yang digunakan. Musik eksternal adalah musik tari yang berasal dari luar diri penari seperti bunyi alat musik tradisional maupun alat musik modern. Iringan terbagi menjadi dua yaitu iringan hidup dan iringan 
rekaman. Iringan hidup memberikan gairah dan suasana yang hidup pada sebuah karya seni pertunjukan sedangkan iringan musik rekaman dapat mempermudah pemain kesenian dan sangat praktis digunakan (Murgiyanto 1983: 98).

Fungsi musik dalam tari sangat penting yaitu sebagai pengiring atau membantu mengekspresikan (penjiwaan) tari, karena dalam praktiknya perpaduan antara musik tari itu sangat erat sekali. Fungsi musik dalam tari diantaranya adalah:

a. Membantu mempertegas irama tari.

Gerak dalam tari berada dalam kerangka irama, irama tari sebenarnya juga dimiliki atau dirasakan oleh si penari. Irama tersebut perlu diperjelas melalui irama musik agar dapat dinikmati oleh penonton.

b. Membantu/mempertegas ekspresi gerak.

Gerakan pada tari sangat beragam yang dilakukan dengan berbagi tekanan. Semua tekanan yang dilakukan dalam gerak tersebut diperjelas oleh musik. Ini dimaksudkan agar semua gerakan tersebut dapat ditampilkan lebih ekspresif.

c. Musik sebagai ilustrasi atau pengantar tari.

Ilusi atau gambaran suasana dalam tari erat kaitannya dengan karakter atau watak tari. Tari dengan watak lembut biasanya ditampilkan dengan gerakangerakan halus dan lembut. Musik dapat membantu membangun karakter tari dengan iringan musik yang lembut atau sebaliknya dengan iringan musik yang keras dan cepat. Dengan demikian musik pemberi illustrasi tidak dipengaruhi oleh irama atau tempo. 
d. Merangsang penari.

Musik mampu memberi semangat pada penari bila musiknya sesuai dengan tema tariannya. Dengan musik gerakan penari menjadi lebih hidup. Musik juga dapat membantu mengingatkan penari jika penari tiba-tiba lupa dengan gerakannya, dengan musik penari dapat melahirkan gerakan improvisasi (Jazuli 2008: 14-16).

Nilai keindahan Iringan dalam pertunjukan tari berfungsi sebagai pengiring sebuah tarian dengan jenis musik tertentu. Penggunaan jenis musik dalam tari menambah nilai wirasa, wirama dan wiraga tarian sehingga tampak lebih indah. Iringan tari dapat bersumber dari gerakan tubuh manusia contohnya hentakan kaki, tepukan tangan, dan suara-suara dari mulut atau bahkan permainan alat musik tradisional atau pribadi. Nilai keindahan iringan dalam tari dapat dilihat dari garap musiknya. Contohnya adalah keras lemahnya bunyi, tempo musik dan permainan melodi, irama dan lagu mampu memberikan kesan emosional yang mendalam, nada-nada yang dihasilkan musik seperti rasa sedih, riang, dan menakutkan merupakan dasar pembentukan suasana-suasana dalam tari, jenis alat atau jenis gending yang digunakan memberikan ilustrasi sebagai penggambaran kondisi suasana yang sedang berlangsung. Fungsi gending di sini membentuk suasana-suasana yang menghantarkan penari bereskpresi. Musik dalam tari mampu memberikan konstribusi kekuatan rasa yang secara komplementer menyatu dengan ekspresi tari sehingga membentuk suatu ungkapan seni atau ungkapan estetis. Wujud kristalisasi tari dan musik adalah untuk mencapai harmonisasi penyajian dalam rangka menghasilkan keutuhan pertunjukan, karena 
pada dasarnya nilai estetis kesenian adalah sebuah ungkapan yang harmoni dan utuh.

\subsubsection{Panggung}

Panggung merupakan tempat atau lokasi yang digunakan untuk menyajikan suatu tarian. Keberadaan panggung mutlak diperlukan, karena tanpa panggung penari tidak bisa menari yang berarti tidak akan dapat diselenggarakan pertunjukan tari. Jenis-jenis panggung yang digunakan untuk pertunjukan tari, terdiri dari dua bentuk panggung yaitu tertutup dan terbuka. Panggung tertutup jenis ragamnya terdiri dari: a) prosenium (untuk dramatari, tarian kelompok, tarian pasangan, dan tarian tunggal); b) pendapa (dramatari, tarian kelompok, tarian pasangan, dan tarian tunggal); dan c) tabang atau panggung keliling (tarian kelompok, tarian pasangan, dan tarian tunggal). Panggung terbuka dapat berbentuk: a) halaman yang sifatnya alami tepat untuk pertunjukan jenis-jenis tari rakyat, b) lapangan untuk jenis-jenis garapan tari yang bersifat kolosal, dan c) jalan untuk pertunjukan jenis-jenis tari yang sifatnya karnaval atau berjalan ini tepat untuk pertunjukan tari-tari: kerakyatan dan garapan tari masal (Maryono 2012: 67).

Panggung (stage) mempunyai bentuk yang bermacam-macam, seperti panggung yang dapat disaksikan penonton dari segala arah disebut panggung arena, panggung leter L yaitu panggung yang disaksikan dari dua sisi memanjang dan sisi melebar, panggung tapal kuda adalah panggung yang dapat disaksikan oleh penonton dari sisi depan dan samping kiri dan kanan, selain dari pada itu panggung yang umum dipergunakan untuk pentas koreografi adalah panggung 
prosenium. Panggung prosenium adalah bentuk panggung tempat penyajian pertunjukan yang hanya dapat disaksikan dari satu arah pandang penontonnya (Hidajat 2011: 63).

Nilai keindahan panggung dengan setting terwujud dalam penataan panggung yang memiliki kualitas pertunjukan yang layak, memadahi dan menarik perlu memperhitungkan dan mempertimbangkan dari segi artistik setting. Bentuk artistik setting panggung yang baik adalah memenuhi syarat-syarat diantaranya: memberikan ilustrasi tema pertunjukan, memberikan ilustrasi setiap adegan pertunjukan, dan memberikan kekuatan ekspresi pertunjukan. Perwujudan tersebut dapat diperoleh dari ragam ornamen atau ilustrasi-ilustrasi gambar, benda maupun dekorasi visual dalam panggung pertunjukan tari. Pada dramatari yang lebih bersifat simbolik setting panggung tidak banyak vareasi ornamen, mencerminkan latar kondisi tema, setting panggungnya menunjukan kesederhanaan bahkan menggunakan dengan memanfaatkan setting alami yang memiliki kekuatan setting yang imajinatif.

\subsubsection{Properti}

Properti (property) adalah istilah dalam bahasa inggris yang berarti alatalat pertunjukan. Pengertian tersebut mempunyai dua tafsiran yaitu property sebagai sets dan property sebagai alat bantu berekspresi. Property merupakan suatu bentuk peralatan penunjang gerak sebagai wujud ekspresi. Karena identitasnya sebagai alat atau peralatan, maka kehadirannya bersifat fungsional. Property tari lebih berorientasi pada kebutuhan-kebutuhan tertentu dalam upaya 
lebih memberikan arti pada gerak, atau sebagai tuntutan ekspresi (Hidajat 2011: $54)$.

Keberadaan properti atau alat-alat yang digunakan sebagai peraga penari sifatnya tentatif. Masing-masing tari memiliki cara, gaya, dan model berekspresi yang berbeda-beda. Kondisi karakter tari yang beragam ini mengakibatkan keberadaan properti tari tidak selalu terdapat dalam pertunjukan tari. Jenis-jenis properti yang lazim digunakan untuk pertunjukan tari, diantaranya: cundrik, keris, condroso, pedang, watang, lawung, tombak, tameng, dadap, gendewa, anak panah/nyenyep, setik, gada, tekbi, boneka, sawunggaling. Kehadiran properti tari memiliki peranan sebagai: a) senjata, b) sarana ekspresi, c) sarana simbolik. Bentuk pemilahan fungsi atau peranan properti tersebut sifatnya tidak mutlak tetapi lebih didasari dari tebal tipisnya penggunaan alat pada pertunjukan tari (Maryono 2012: 67-68).

Properti tari yang digunakan untuk alat senjata, dapat diamati pada genre tari Pethilan, diantaranya: senjata pada tari Anila Prahastha, senjata gendewa dan anak panah pada tari Adaninggar Kelaswara. Bentuk properti yang difungsikan sebagai senjata juga banyak dimanfaatkan dalam garapan-garapan dramatari seperti: cundrik, keris, pedang gendewa, anak panahnyenyep, tombak, tameng. Jenis-jenis properti tari yang difungsikan sebagai sarana ekspresi adalah jenisjenis properti yang secara substansial menjadi dasar penggarapan gerak dalam tari. Bentuk-bentuk properti pedang dan tameng misalnya pada tari Eko Prawira. Gendewa dan keris merupakan properti pada tari jemparingan. Bentuk-bentuk properti yang difungsikan sebagai sarana simbolik tari adalah jenis-jenis properti 
yang memiliki makna yang dalam berkaitan dengan peran tari. Jenis tersebut seperti properti boneka yang digunakan pada sajian tari Bondhan Sayuk (Maryono 2012: 68).

Properti dalam sebuah koreografi bersifat fungsional dan sangat khas. Properti dapat memperkuat laku-laku, serta memberikan makna-makna tambahan, yang dalam beberapa hal, merupakan pokok makna tarian secara keseluruhan. Properti merupakan salah satu wujud bawaan yang berbeda antara koreografi yang satu dengan yang lainnya. Kehadiran tokoh atau peran dalam koreografi adalah berupa wujud penari yang memvisualisasikan kesatuan karakter dalam bentuk penari kelompok. Hal yang paling mendasar dalam mempertimbangkan kehadiran tokoh adalah pemikiran tentang pemilihan motif gerak, gaya yang dirujuk serta elemen pendukung lainnya, seperti properti. Properti dapat dijadikan sebagai identitas diri, penggambaran suatu keadaan, pembentuk garis tertunda, penggambaran objek manusia atau binatang dan sebagai musik internal yang dimainkan sebagai alat bantu menari sehingga bunyi-bunyian yang terjadi adalah karena gerakan-gerakan penari dengan properti (Hidajat 2011: 60-62).

Nilai keindahan properti dalam suatu sajian tari difungsikan sebagai pelengkap sajian tari. Penggunaan properti saat menari menimbulkan tenaga yang digunakan dalam ragam gerak tertentu terlihat jelas. Kesan yang muncul secara jelas mampu memperlihatkan nilai keindahan tari melalui properti tari yang digunakan. Properti tari juga digunakan sebagai cara menyampaikan pesan dalam tarian yang sedang dipertunjukan melalui simbol-simbol yang terwujud. Dengan 
menggunakan properti dalam suatu pertunjukan tari sehingga penonton lebih memahami dan menangkap isi dan penampilan tari.

\subsubsection{Pencahayaan}

Tata Lampu atau lighting harus diperhatikan karena lighting ini untuk pentas bukan hanya sekedar untuk penerang semata tetapi juga berfungsi untuk menciptakan suasana atau efek dramatik. Lampu-lampu khusus yang disebut spot light adalah yang paling ideal karena dengan lampu khusus daerah yang lemah pun bisa menjadi daerah yang kuat. Juga bisa memakai lampu dengan warnawarna khusus atau disebut colour medium yang bisa memberi suasana tertentu. Tetapi perlu diperhatikan penggunaan colour medium dengan kostum yang sewarna karena akan menghapus warna pada kostum dan rias wajah. Contoh, colour medium warna merah akan menghapus kostum warna merah, bahkan bila sama-sama kuat warna merah akan berubah menjadi putih. Colour medium warna kuning muda akan memperjelas warna kostum, sedangkan warna biru dapat memberi suasana sayu (Jazuli 2008: 28-29).

Tata cahaya merupakan bagian dari unsur perlengkapan suatu pertunjukkan. Tata cahaya berfungsi membantu kesuksesan dalam sebuah pertunjukkan. Tata cahaya dapat merupakan unsur yang memperjelas dan mempertegas ide yang disampaikan kepada penonton. Pada zaman modern ini juga dapat bermanfaat untuk menimbulkan efek tertentu pada pertunjukkan. Penataan lampu atau sinar bukanlah sekedar sebagai penerang semata melainkan berfungsi untuk menciptakan suasana atau efek dramatic dan memberikan daya 
hidup pada sebuah pertunjukan seni, baik langsung maupun tidak langsung (Jazuli 2008: 30).

Nilai keindahan pencahayaan atau cahaya lampu untuk menerangi dan menyinari arena permainan serta menimbulkan efek artistik. Tata cahaya adalah seni pengaturan cahaya dengan mempergunakan peralatan pencahayaan agar kamera mampu melihat obyek dengan jelas dan menciptakan ilusi sehingga penonton mendapatkan kesan adanya jarak, ruang, waktu dan suasana dari suatu kejadian yang dipertunjukan dalam suatu pementasan. Penggunaaan berbagai macam warna cahaya dalam suatu adegan tari menambah nilai keindahan tersendiri. Melalui pencahayaan yang tepat tari akan terlihat semakin jelas, menarik dan menciptakan suasana mencekam maupun ramai. Penggunaan cahaya untuk membuat bagian-bagian pentas sesuai dengan keadaan lakon dan menyinari daerah tertentu maka akan ada sesuatu atau suasana yang lebih hendak ditonjolkan agar tercapai efek dramatik. 


\subsection{KERANGKA BERPIKIR}

TARI LENGGANG PARI DI SANGGAR SENI PERWITASARI

KELURAHAN KEMANDUNGAN KECAMATAN TEGAL BARAT

KOTA TEGAL

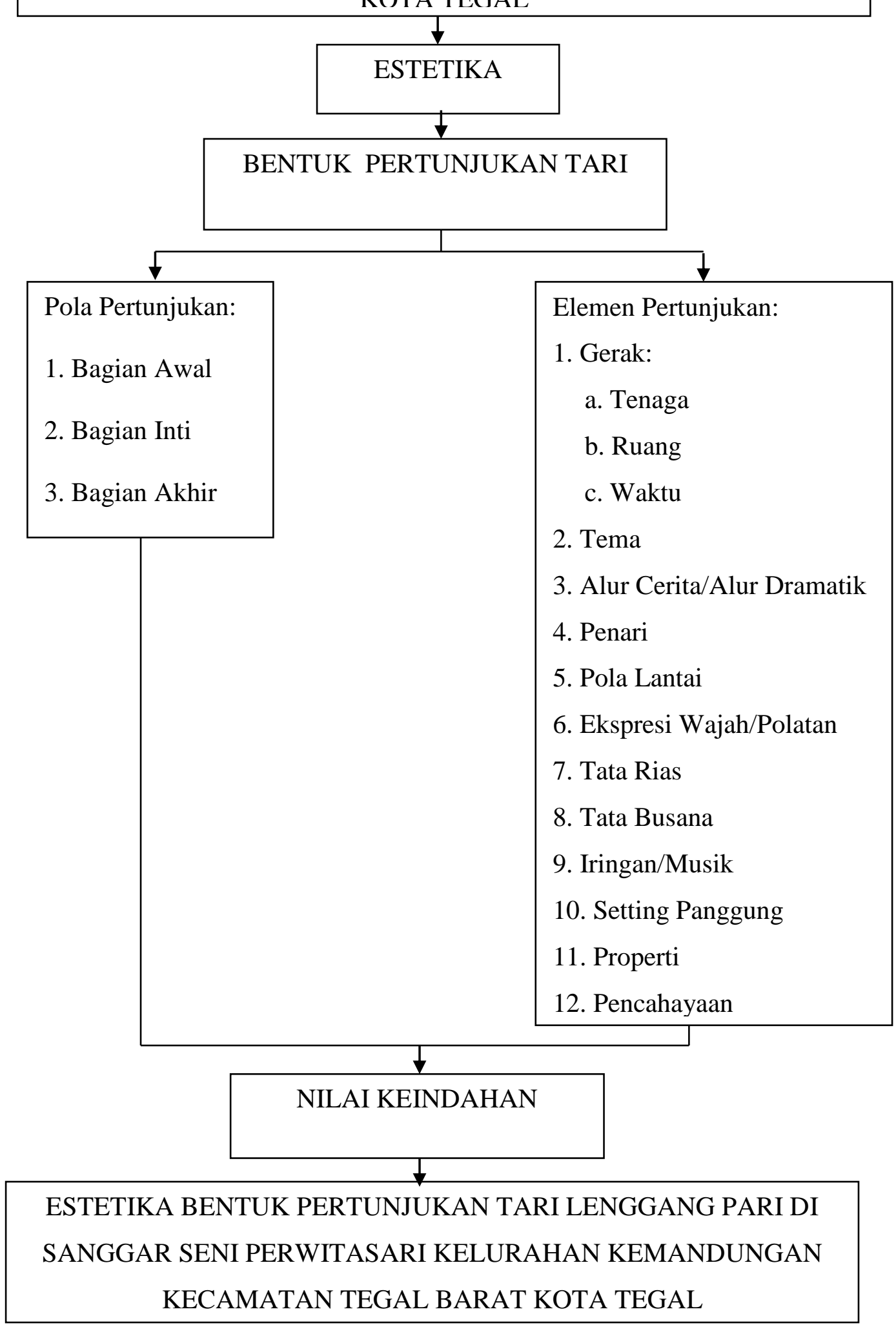




\section{BAB III}

\section{METODE PENELITIAN}

\subsection{Metode Penelitian}

\subsubsection{Pendekatan Deskriptif Kualitatif}

Penelitian mengenai Estetika Bentuk Pertunjukan Tari Lenggang Pari di Sanggar Seni Perwitasari Kelurahan Kemandungan Kecamatan Tegal Barat Kota Tegal menggunakan metode penelitian deskriptif kualitatif, dengan tujuan untuk menggambarkan dan menjelaskan suatu keadaan sebagaimana adanya serta dapat dipertanggungjawabkan kebenarannya. Metode penelitian kualitatif adalah metode penelitian yang berlandaskan pada filsafat postpositivisme, digunakan untuk meneliti pada kondisi obyek yang alamiah, (sebagai lawannya adalah eksperimen) dimana peneliti adalah sebagai sumber data dilakukan secara purposive dan snowboal, teknik pengumpulan data triangulasi (gabungan), analisis data bersifat induktif/kualitatif lebih menekankan makna dari pada generalisasi (Sugiyono 2008: 15).

Penelitian dengan jenis kualitatif lebih menekankan analisisnya pada proses penyimpulan deduktif dan induktif serta pada analisis terhadap dinamika hubungan antarfenomena yang diamati, dengan menggunakan logika ilmiah. Pendekatan penelitian kualitatif penekanannya pada usaha menjawab pertanyaan penelitian melalui cara-cara berfikir formal dan argumentatif (Azwar 2013: 5).

Penelitian kualitatif bertujuan untuk memperoleh informasi-informasi penting untuk diteliti. Data kualitatif merupakan sumber dari deskripsi yang luas dan berlandasan kokoh serta memuat penjelasan tentang proses-proses yang 
terjadi dalam lingkungan setempat. Data kualitatif bukan berupa angka-angka dalam hal ini datanya berupa deskripsi yang berwujud kata-kata atau kalimat yang diperoleh dari hasil wawancara, catatan lapangan, observasi, dokumen dan rekaman suara dan diproses sebelum siap digunakan sebagai bahan, diproses melalui beberapa proses yakni pencatatan, pengetikan, atau alih tulis. Metode penelitian kualitatif sering disebut metode penelitian naturalistik karena penelitiannya dilakukan pada kondisi yang alamiah (natural setting); disebut juga sebagai metode etnographi, karena pada awalnya metode ini lebih banyak digunakan untuk penelitian bidang antropologi budaya; disebut sebagai metode kualitatif, karena data yang terkumpul dan analisisnya lebih bersifat kualitatif (Sugiyono 2008: 14).

Alur penelitian kualitatif memiliki beberapa karakteristik. Karakteristik penelitian dengan pendekatan kualitatif menurut Moeloeng (2007: 8-13) adalah:

1. Penelitian kualitatif memiliki latar alamiah sebagai sumber data.

2. Peneliti sebagai instrumen utama penelitian.

3. Metode pengamatan, wawancara dan penelaahan dokumen.

4. Analisa secara induktif.

5. Penelitian menghendaki adanya arah bimbingan penyusunan teori subtantif yang berasal dari data.

6. Data berupa kata-kata, gambar, dan bukan angka-angka (deskriptif).

Alasan peneliti menggunakan metode kualitatif dalam penelitian mengenai Estetika Bentuk Pertunjukan Tari Lenggang Pari di Sanggar Seni Perwitasari Kelurahan Kemandungan Kecamatan Tegal Barat Kota Tegal karena penelitian 
deskriptif melakukan analisis hanya sampai pada taraf deskripsi, yaitu menganalisis dan menyajikan fakta secara sistematik sehingga dapat lebih mudah untuk difahami dan disimpulkan. Kesimpulan yang diberikan selalu jelas dasar faktualnya sehingga semuanya selalu dapat dikembalikan langsung pada data yang diperoleh. Uraian kesimpulan didasari oleh angka yang diolah tidak secara terlalu dalam. Kebanyakan pengolahan datanya didasarkan pada analisis presentase dan analisis kecenderungan (trend). Penelitian deskriptif bertujuan menggambarkan secara sistematik dan akurat fakta dan karakteristik mengenai populasi atau mengenai bidang tertentu. Penelitian ini berusaha menggambarkan situasi atau kejadian. Data yang dikumpulkan semata-mata bersifat deskriptif sehingga tidak bermaksud mencari penjelasan, menguji hipotesis, membuat prediksi, maupun mempelajari implikasi (Azwar 2013: 6-7). Peneliti ingin menganalisis dan memperoleh gambaran secara luas dan mendalam tentang Estetika Bentuk Pertunjukan Tari Lenggang Pari di Sanggar Seni Perwitasari Kelurahan Kemandungan Kecamatan Tegal Barat Kota Tegal.

Penelitian kualitatif budaya dipandang penting, untuk melihat kondisi yang tidak mungkin dijangkau dengan rumus-rumus kuantitatif. Penelitian model ini lebih menitik beratkan keutuhan (entity) sebuah fenomena budaya, bukan memandang budaya secara parsial. Dalam kaitan ini, unsur pengamatan sangat menentukan keberhasilan penelitian. Terlebih lagi pengamatan berpatisipasi jelas amat penting bagi terlaksananya penelitian budaya (Endraswara 2012: 16).

Metode deskriptif kualitatif sangat diperlukan dalam mengumpulkan data penelitian mengenai Estetika Bentuk Pertunjukan Tari Lenggang Pari di Sanggar 
Seni Perwitasari Kelurahan Kemandungan Kecamatan Tegal Barat Kota Tegal karena penelitian deskriptif kualitatif menggambarkan keadaan nyata dilingkungan tempat observasi. Peneliti menjadi instrumen kunci dalam proses penelitian kualitatif karena peneliti ikut berbaur dan terlibat langsung dalam rangkaian kegiatan yang menjadi objek penelitian untuk mengkaji estetika yang terkandung dalam tari Lenggang Pari tersebut.

Penelitian mengenai Estetika Bentuk Pertunjukan Tari Lenggang Pari di Sanggar Seni Perwitasari Kelurahan Kemandungan Kecamatan Tegal Barat Kota Tegal ini menggunakan beberapa pendekatan. Pendekatan yang digunakan adalah pendekatan estetis koreografis, pendekatan etik, pendekatan emik.

\subsubsection{Pendekatan Estetis Koreografis}

Pendekatan estetis koreografis yaitu keindahan yang dilihat melaui aspekaspek koreografi. Pendekatan ini digunakan pertama oleh peneliti untuk memperoleh gambaran tentang aspek koreografi yaitu gerak sebagai elemen pokok tari (tenaga, ruang, dan waktu) serta unsur pendukungnya seperti iringan, rias wajah dan busana, tempat pertunjukan, waktu pertunjukan, tata cahaya, properti (Murgiyanto 1983: 10-15). Elemen atau aspek-aspek dalam sebuah koreografi ini merupakan kesatuan bentuk yang utuh. Jadi, peneliti mendeskripsikan nilai keindahan yang ada dalam tari Lenggang Pari melalui bentuk tari yang terdiri dari unsur pokok dan unsur pendukung tari.

Secara garis besar estetika dipilahkan menjadi dua golongan, yakni: (1) estetika tentang alam yang tidak diciptakan manusia dan (2) estetika yang diciptakan dan diwujudkan oleh manusia. Secara substansial estetika ciptaan 
Tuhan bersifat sempurna, sedang estetika buatan manusia bersifat imitasi yang meniru estetika ciptaan Tuhan. Estetika buatan manusia merupakan sebuah studi tentang keindahan dan lebih luas merupakan suatu kepekaan untuk menanggapi suatu objek, kemampuan pencerapan indra, sebagai sensitivitas. Dalam menikmati estetika suatu karya seni tidak hanya dilihat dari kemasannya saja, namun juga faktor-faktor dari luar objek yang mendukungnya (Djelantik 1999: 17-18).

Pendekatan dalam suatu penelitian memiliki dua pokok pembahasan yang sebenarnya saling terkait, yakni memandang karya seni tari secara bentuk fisik atau intraestetik dan melalui konteks bagaimana tari tersebut dipandang bersama ilmu pengetahuan yang lain atau ekstraestetik. Peneliti melihat tari Lenggang Pari lewat wujud tekstualnya secara koreografis, dibantu oleh teori Hayes dengan kesatuan, keberagaman, repetisi, kontras, transisi, rangkaian, klimaks, proporsi, keseimbangan, dan keselarasan. Teori Hayes mengenai prinsip bentuk seni ini digunakan untuk menunjukkan sisi estetis koreografinya (Wisyastutieningrum 2014: 75).

\subsubsection{Pendekatan Emik \& Etik}

Peniliti memperoleh data dengan menggunakan dua pendekatan lain. Namun pendekatan ini memiliki peran yang sama pentingnya dalam sebuah penelitian. Dua pendekatan yang dimaksud adalah pendekatan emik dan etik. Pendekatan Emik dimana data diperoleh dari pengkategorian fenomena budaya menurut warga setempat yang memberi gambaran secermat mungkin mengenai 
suatu individu, keadaan, gejala atau kelompok-kelompok tertentu serta Etik dimana data yang diperoleh dari sudut pandang peneliti (Endraswara 2012: 35).

Pendekatan emik merupakan esensi yang sahih untuk satu bahasa atau satu kebudayaan pada satu waktu tertentu, pendekatan emik merupakan usaha untuk mengungkap dan menguraikan pola suatu bahasa atau kebudayaan tertentu dari cara unsur-unsur bahasa atau kebudayaan itu berkaitan satu dengan lainnya dalam melakukan fungsi sesuai dengan pola tersebut. Pendekatan emik adalah struktur yang berarti penulis berasumsi bahwa perilaku manusia terpola dalam sistem pola itu sendiri dengan tujuan mengungkapkan dan menguraikan sistem perilaku bersama satuan strukturnya dan kelompok struktual satuan-satuan itu (Moeloeng 2012: 82).

Pendekatan etik merupakan aplikasi pada tahap permulaan penelitian emik, suatu klarifikasi etik telah dibuat atas dasar tipe-tipe yang telah disusun sebelumnya terhadap sistem kultur atau bahasa tertentu dalam contoh demikian pendekatan etik adalah pra struktural, dengan penggunaan cara khusus sebagai perkiraan sampai mencapai analisis sistem struktur bahasa dan kultur etik. Analisis memiliki salah satu diantara banyak kemungkinan klasifikasi etik umum yang mengarahkannya kepada pengalaman untuk sejauh unsur-unsur yang tercatat secara sistematis dan dikemukakan oleh analisis sebagai kerangka semua kebudayaan atas dasar pengalaman umum sebelum memulai kegiatan analisis emiknya dalam kebudayaan tertentu (Moelong 2012: 83).

Menurut Ensraswara (2012: 36) karakteristik pendekatan etik dan emik akan mengikat peneliti budaya, seperti terlihat pada tabel berikut: 


\begin{tabular}{|c|c|}
\hline Etik & Emik \\
\hline $\begin{array}{l}\text { a. Peneliti budaya akan mempelajari } \\
\text { perilaku manusia dari luar } \\
\text { kebudayaan objek penelitiannya }\end{array}$ & $\begin{array}{l}\text { a. Peneliti mempelajari perilaku } \\
\text { manusia dari dalam objek } \\
\text { penelitiannya }\end{array}$ \\
\hline $\begin{array}{l}\text { b. Penelitian mengkaji lebih dari satu } \\
\text { kebudayaan dan } \\
\text { membandingkannya }\end{array}$ & $\begin{array}{l}\text { b. Peneliti hanya mengkaji suatu } \\
\text { kebudayaan }\end{array}$ \\
\hline $\begin{array}{l}\text { c. Struktur kebudayaan ditentukan } \\
\text { oleh peneliti, dengan membangun } \\
\text { konseptual }\end{array}$ & $\begin{array}{l}\text { c. Struktur ditentukan oleh kondisi yang } \\
\text { ditemukan di lapangan }\end{array}$ \\
\hline $\begin{array}{l}\text { d. Kriteria kebudayaan bersifat } \\
\text { mutlak, ada generalisasi, dan } \\
\text { berlaku universal }\end{array}$ & $\begin{array}{l}\text { d. Kriteria kebudayaan bersifat relatif } \\
\text { dan terbatas }\end{array}$ \\
\hline
\end{tabular}

Berdasarkan tabel diatas, nampak bahwa peneliti budaya emik akan menjadikan dirinya sebagai bagian utuh kebudayaan yang diteliti. Peneliti ikut merasakan dan bertindak sebagai partisipan penuh. Sedangkan peneliti budaya etik, otoritas peneliti sangat menentukan. Kemampuan peneliti membangun konsep yang diterapkan, amat menentukan keberhasilan.

Tari Lenggang Pari tergolong tarian yang baru, tetapi pola geraknya menggunakan gerak tari Jawa. Penganalisisan tari Lenggang Pari menggunakan pendekatan emik karena istilah-istilah yang dipakai merupakan nama atau bahasa yang ada dalam tari Jawa, seperti ukel karno, tawing, nanggung, tanjak, 
junjungan, mendhak, srisig, ngrayung dan ngiting. Pendekatan etik diperlukan peneliti apabila tidak ditemukan istilah-istilah atau bahasa yang ada dalam pendekatan emik, sehingga peneliti harus membuat kode sendiri sebagai perkiraan sampai mencapai analisis sistem struktur bahasa dan kultur etik.

\subsection{Data dan Sumber Data}

\subsubsection{Lokasi Penelitian}

Lokasi penelitian, setting menurut pemahaman adalah tempat didalamnya penelitian dilakukan (Kutha Ratna 2007: 296). Lokasi ditentukan oleh data, maka permasalahannya adalah kembali ke data sedangkan lokasi berfungsi untuk mengikuti kepentingan data tersebut. Lokasi yang dianggap baik belum tentu menyediakan data yang baik, tetapi data yang baik harus diusahakan untuk diteliti (Kutha Ratna 2007: 300).

Lokasi penelitian terletak di Kelurahan Kemandungan Kecamatan Tegal Barat Kota Tegal tepatnya di Sanggar Seni Perwitasari yang dipimpin oleh Ibu Damayanti dan Bapak Priambodo sebagai lokasi utama penelitian. Lokasi penelitian terletak di pusat kota dan dapat ditempuh menggunakan kendaraan bermotor.

\subsubsection{Sasaran Penelitian}

Objek yang diteliti dalam penelitian mengenai Estetika Bentuk Pertunjukan Tari Lenggang Pari di Sanggar Seni Perwitasari Kelurahan Kemandungan Kecamatan Tegal Barat Kota Tegal adalah tari Lenggang Pari yang bertempat di Sanggar Seni Perwitasari Kelurahan Kemandungan Kecamatan Tegal Barat Kota Tegal beserta aspek-aspek yang mendukung baik pemilik 
sanggar, penari, pemusik dan beberapa orang penikmat tari Lenggang Pari, sedangkan sasaran dalam penelitian ini yaitu pada Estetika Bentuk Pertunjukan Tari Lenggang Pari di Sanggar Seni Perwitasari Kelurahan Kemandungan Kecamatan Tegal Barat Kota Tegal.

\subsection{Teknik Pengumpulan Data}

Pengumpulan data dalam penelitian ini menggunakan metode observasi, wawancara dan dokumentasi.

\subsubsection{Observasi}

Observasi adalah dasar semua ilmu pengetahuan. Observasi adalah pengamatan dan pencatatan dengan sistematik fenomena-fenomena yang diteliti. Observasi disebut juga dengan pengamatan meliputi kegiatan pemusatan terhadap suatu objek dengan menggunakan seluruh alat indera, jadi mengobservasi dapat dilakukan melalui indera penglihatan, penciuman, pendengaran, peraba dan pengecap. Teknik pengumpulan data dengan observasi digunakan bila, penelitian berkenaan dengan perilaku manusia, proses kerja, gejala-gejala alam dan bila responden yang diamati tidak terlalu besar (Sugiyono 2008: 203).

Observasi merupakan suatu proses yang kompleks, suatu proses yang tersusun dari berbagai proses biologis dan psikologis. Dua di antara yang terpenting adalah proses-proses pengamatan dan ingatan (Hadi, 1996:25). Teknik observasi berperan aktif, peneliti selain sebagai pengamat juga mengambil peran dengan mempertimbangkan posisi yang dapat memberikan akses sehingga dapat dimanfaatkan untuk memperoleh data yang lengkap dan mendalam. Dampak 
kedatangan peneliti terhadap objek yang diteliti kadarnya lebih besar dari pada observasi berperan pasif (Maryono 2011: 106).

Observasi menurut Arikunto (2010: 146) adalah pengamatan secara langsung atau kegiatan pemusatan perhatian terhadap suatu objek dengan menggunakan seluruh alat indera. Berdasarkan jenisnya, observasi dibagi menjadi dua yaitu:

a. Observasi langsung yaitu observasi atau pengamatan yang dilakukan dimana pengamat berada bersama obyek yang diselidiki

b. Observasi tidak langsung yaitu observasi atau pengamatan yang dilakukan tidak pada saat berlangsung suatu peristiwa yang akan diteliti

Penelitian mengenai Estetika Bentuk Pertunjukan Tari Lenggang Pari di Sanggar Seni Perwitasari Kelurahan Kemandungan Kecamatan Tegal Barat Kota Tegal, peneliti melakukan observasi langsung ke sasaran penelitian yaitu di Kelurahan Kemandungan Kecamatan Tegal Barat Kota Tegal tepatnya di Sanggar Seni Perwitasari milik Ibu Damayanti dan Bapak Priambodo selaku pimpinan dari sanggar seni tersebut. Observasi dilakukan untuk memperoleh data mengenai Estetika Bentuk Pertunjukan Tari Lenggang Pari di Sanggar Seni Perwitasari Kelurahan Kemandungan Kecamatan Tegal Barat Kota Tegal dengan kajian pokok nilai keindahan bentuk tari yang dianalisis melalui aspek pokok koreografi dan aspek pendukungnya yang terwujud melalui bentuk pertunjukan tari Lenggang Pari. Tahap observasi dilakukan dengan cara mengamati pertunjukan tari, tempat pertunjukan dan lingkungan sekitar tempat latihan. 
Teknik observasi dilakukan dengan melihat proses pertunjukan tari Lenggang Pari dalam berbagai acara. Alat yang digunakan dalam proses dokumentasi berupa kamera digital untuk foto dan vidio serta handphone untuk merekam proses wawancara. Penelitian dilakukan beberapa tahap dan dilakukan di beberapa tempat untuk memperoleh data yang akurat mengenai estetika bentuk pertunjukan tari Lenggang Pari.

Untuk memperoleh data yang valid, peneliti juga terjun langsung dan menyaksikan pertunjukan tari Lenggang Pari. Observasi pada tanggal 12 Maret 2017 dilakukan di tempat pertunjukan pementasan tari Lenggang Pari yaitu di Desa Ketanggungan Brebes dalam rangka panen raya nasional padi MSP. Hasil observasi memperoleh data mengenai bentuk pertunjukan tari Lenggang Pari serta untuk memperoleh dokumentasi pertunjukan tari Lenggang Pari secara keseluruhan.

Observasi selanjutnya dilakukan pada tanggal 9 April 2017 di rumah Priambodo selaku ketua Sanggar Seni Perwitasari di kelurahan Kemandungan. Hasil observasi memberikan penjelasan mengenai sejarah berdirinya Sanggar Seni Perwitasari dan penciptaan tari Lenggang Pari. Proses penciptaan gerak tari Lenggang Pari, bentuk pertunjukan tari Lenggang Pari secara keseluruhan dari aspek pokok gerak sampai aspek pendukung berupa rias, busana, tata cahaya, pelaku, tempat, properti. Proses latihan tari Lenggang Pari hingga persiapan dalam pertunjukan tari Lenggang Pari serta keunikan yang terdapat dalam tari Lenggang Pari yang membuat pertunjukannya menarik sehingga penonton mampu menikmati pertunjukan tari Lenggang Pari. 
Observasi pada tanggal 11 s/d 12 April 2017 di SD Negeri Kejambon 4. Hasil observasi memberikan penjelasan mengenai proses latihan tari Lenggang Pari, teknik dalam melakukan gerak tari Lenggang Pari, penyusunan komposisi pada tari Lenggang Pari, persiapan dalam pertunjukan tari Lenggang Pari secara keseluruhan. Observasi pada tanggal 13 April 2017 dilakukan di tempat pertunjukan pementasan tari Lenggang Pari yaitu di gedung Pusat Kegiatan Guru Kecamatan Tegal Timur Kota Tegal dalam rangka FLS2N tahun 2017 Kecamatan Tegal Timur Kota Tegal. Hasil observasi memperoleh data mengenai bentuk pertunjukan tari Lenggang Pari serta untuk memperoleh dokumentasi pertunjukan tari Lenggang Pari secara keseluruhan.

Observasi pada tanggal 12 April 2017 pukul 10.00 WIB - selesai di Kelurahan Kemandungan Kecamatan Tegal Barat Kota Tegal untuk memperoleh data mengenai letak dan kondisi geografis lokasi penelitian, kehidupan sosial budaya masyarakat, kesenian yang tumbuh dan berkembang di Sanggar Seni Perwitasari khususnya serta upaya-upaya yang dilakukan pihak kelurahan untuk melestarikan tari Lenggang Pari dan kebudayaan yang ada di Kelurahan Kemandungan.

Observasi pada tanggal 18 April 2017 dilakukan di rumah Nugroho selaku penata iringan tari Lenggang Pari. Hasil observasi memperoleh data mengenai penjelasan alat-alat musik yang digunakan dalam pembuatan musik tari Lenggang Pari beserta tembang-tembang dan notasi garap. Observasi pada tanggal 25 April 2017 dilakukan di Pendopo Ki Gede Sebayu, peneliti melakukan observasi dengan 4 penari tari Lenggang Pari. Hasil observasi memperoleh data mengenai 
bentuk pertunjukan tari Lenggang Pari dari aspek dasar yaitu gerak dan aspek pendukung meliputi tata rias, tata busana, iringan, tempat, properti. Jadwal latihan di Sanggar Seni Perwitasari serta proses latihan tari Lenggang Pari.

Teknik observasi yang digunakan oleh peneliti adalah observasi langsung yaitu peneliti datang di tempat kegiatan orang yang diamati. Selain itu peneliti juga dapat berkomunikasi secara akrab dan leluasa, sehingga memungkinkan untuk bertanya lebih rinci dan detail terhadap hal-hal yang akan diteliti. Teknik yang digunakan peneliti sangat menguntungkan karena dapat mengamati langsung dan dapat mengambil dokumentasi dengan menggunakan kamera untuk mengambil gambar maupun video segala aktivitas yang dilakukan sebelum dan saat pementasan tari Lenggang Pari.

\subsubsection{Wawancara}

Wawancara digunakan sebagai teknik pengumpulan data apabila peneliti ingin melakukan studi pendahuluan untuk menemukan permasalahan yang harus diteliti, tetapi juga apabila peneliti ingin mengetahui hal-hal dari responden yang lebih mendalam. Teknik pengumpulan data ini mendasarkan diri pada laporan tentang diri sendiri atau self-report, atau setidak-tidaknya pada pengetahuan dan keyakinan pribadi (Sugiyono 2009: 317). Menurut Sugiyono (2009: 318-319) mengemukakan beberapa macam wawancara, yaitu wawancara terstruktur, semiterstruktur, dan tidak terstruktur.

\section{Wawancara terstruktur (structured interview)}

Wawancara terstruktur digunakan sebagai teknik pengumpulan data, bila peneliti atau pengumpul data telah mengetahui dengan pasti tentang informasi apa 
yang akan diperoleh. Oleh karena itu dalam melakukan wawncara, pengumpul data telah menyiapkan instrumen penelitian berupa pertanyaan-pertanyaan tertulis yang alternatif jawabannya pun telah disiapkan.

\section{Wawancara semiterstruktur (semistructure Interview)}

Jenis wawancara ini sudah termasuk dalam kategori ind-depth interview, dimana dalam pelaksanaannya lebih bebas bila dibandingkan dengan wawancara terstruktur. Tujuan dari wawancara terstruktur. Tujuan dari wawancara jenis ini adalah untuk menemukan permasalahan secara lebih terbuka.

\section{Wawancara tak berstruktur (unstructured interview)}

Wawancara tidak terstruktur, adalah wawancara yang bebas dimana peneliti tidak menggunakan pedoman wawancara yang telah tersusun secara sistematis dan lengkap untuk pengumpulan datanya. Pedoman wawancara yang digunakan hanya berupa garis-garis besar permasalahan yang ditanyakan.

Penelitian kualitatif sering menggunakan teknik wawancara mendalam. Selama melakukan observasi, peneliti juga melakukan wawancara kepada orangorang di dalamnya. Sebelum melakukan wawancara, peneliti mempersiapkan instrumen pertanyaan berupa sejumlah pertanyaan atau pertanyaan yang meminta untuk dijawab atau direspon oleh terwawancara. Peneliti dapat bertatap muka langsung dengan pihak yang terkait dengan pertunjukan tari Lenggang Pari. Langkah-langkah yang digunakan dalam teknik wawancara menurut Sugiyono adalah 1) menetapkan siapa yang akan diwawancara, 2) menyiapkan instrumen wawancara, 3) mengawali alur wawancara, 4) melangsungkan alur wawancara, 5) mengkonfirmasikan hasil wawancara dan mengakhiri, 6) menuliskan hasil 
wawancara, 7) mengidentifikasikan tidak lanjut hasil wawancara yang telah diperoleh (Sugiyono 2009: 322).

Proses wawancara dilakukan peneliti untuk memperoleh data yang jelas dan rinci tentang estetika bentuk tari Lenggang Pari, peneliti memilih narasumber yang mampu memberikan data akurat. Adapun narasumber yang diwawancarai adalah sebagai berikut:

1) Ketua atau pemimpin sanggar seni perwitasari

Wawancara dilakukan pada tanggal 9 April 2017 pukul 16.00 WIB dengan informan Priambodo selaku ketua sanggar seni perwitasari dan Damayanti selaku penata gerak tari Lenggang Pari. Hasil wawancara memberikan penjelasan mengenai sejarah berdirinya Sanggar Seni Perwitasari dan penciptaan tari Lenggang Pari. Proses penciptaan gerak tari Lenggang Pari, bentuk pertunjukan tari Lenggang Pari secara keseluruhan dari aspek pokok gerak sampai aspek pendukung berupa rias, busana, tata cahaya, pelaku, tempat, properti. Proses latihan tari Lenggang Pari hingga persiapan dalam pertunjukan tari Lenggang Pari serta keunikan yang terdapat dalam tari Lenggang Pari yang membuat pertunjukannya menarik sehingga penonton mampu menikmati pertunjukan tari Lenggang Pari.

2) Lurah dan Kasi Tata Pemerintahan Kelurahan Kemandungan Kecamatan Tegal Barat Kota Tegal

Wawancara dilakukan pada tanggal 12 April 2017 dengan informan Imam Surokhim selaku lurah dan Darmawan selaku Kasi Tata Pemerintahan Kelurahan Kemandungan. Hasil wawancara memperoleh data mengenai letak dan kondisi 
geografis lokasi penelitian, kehidupan sosial budaya masyarakat. Kesenian yang tumbuh dan berkembang serta upaya-upaya yang dilakukan pihak kelurahan untuk melestarikan kebudayaan daerah seperti tari Lenggang Pari di Kelurahan Kemandungan.

3) Pemusik

Wawancara dilakukan pada tanggal 18 April 2017 dengan Nugroho dan 31 Juli 2017 dengan Slamet Waluyo selaku penata iringan. Hasil wawancara yaitu untuk mengetahui jenis iringan yang digunakan, alat musik yang dipakai, dan gendhing-gendhing yang dipakai dalam pertunjukan tari Lenggang Pari beserta tembang-tembang dan notasi garap.

4) Penari

Wawancara dilakukan pada tanggal 25 April 2017 dengan Zulfa, Dimas, Wike dan Putri selaku penari. Hasil wawancara memperoleh data mengenai bentuk pertunjukan tari Lenggang Pari dari aspek dasar yaitu gerak dan aspek pendukung meliputi tata rias, tata busana, iringan, tempat, properti. Jadwal latihan di Sanggar Seni Perwitasari serta proses latihan tari Lenggang Pari.

\subsubsection{Dokumentasi}

Dokumen merupakan catatan peristiwa yang sudah berlalu. Dokumen bisa berbentuk tulisan, gambar, atau karya-karya monumental dari seseorang. Studi dokumen merupakan pelengkap dari penggunaan metode observasi dan wawancara dalam penelitian kualitatif (Sugiyono 2012: 329). Dokumen digunakan dalam penelitian sebagai sumber data karena dalam banyak hal 
dokumen sebagai sumber data dimanfaatkan untuk menguji, menafsirkan, bahkan untuk meramalkan (Moleong 2012: 217).

Teknik dokumentasi adalah cara yang digunakan untuk mencari data mengenai hal-hal atau variabel yang berupa catatan, transkrip, buku, surat kabar, majalah, prasasti, notulen rapat, agenda, dan sebagainya (Arikunto 2013: 274).

Teknik dokumentasi digunakan untuk memperoleh data tentang estetika bentuk pertunjukan tari Lenggang Pari. Dokumen yang digunakan peneliti disini meliputi: 1) peta wilayah Kelurahan Kemandungan; 2) data statistik Kelurahan Kemandungan; 3) catatan mengenai tari Lenggang Pari berupa foto, gambar, rekaman, video dokumentasi pertunjukan tari Lenggang Pari. Pengumpulan dokumentasi yang diperoleh dapat memperkuat informasi yang diberikan oleh informan, sehingga gambar atau foto yang diambil dapat dijadikan sebagai bukti otentik agar hasil observasi tetap terjaga validitasnya.

\subsection{Teknik Analisis Data}

Analisis data adalah proses mencari dan menyusun secara sistematis data yang diperoleh dari hasil wawancara, catatan lapangan, dan dokumentasi, dengan cara mengorganisasikan data ke dalam kategori, menjabarkan ke dalam unit-unit, melakukan sintesa, menyusun ke dalam pola, memilih mana yang penting dan yang akan dipelajari, dan membuat kesimpulan sehingga mudah dipahami oleh diri sendiri maupun orang lain (Sugiyono 2012: 335).

Analisis mengenai Estetika Bentuk Pertunjukan Tari Lenggang Pari menggunakan langkah-langkah dan proses analisa tari menurut konsep Adshead. Menurut Janet Adshead dalam Murgiyanto (2002: 9-10), dalam bukunya Dance 
Analysis: Theory and Practice, membagi proses analisa tari ke dalam empat tahap sebagai berikut:

1. Mengenali dan mendeskripsikan komponen-komponen pertunjukan tari seperti gerak, penari, aspek visual, dan elemen-elemen auditif.

2. Memahami hubungan antara komponen pertunjukan dalam perjalanan ruang dan waktu: bentuk dan struktur koreografi.

3. Melakukan interpretasi berdasarkan konsep dan latar belakang sosial, budaya, konteks pertunjukan, gaya dan genre, tema, isi tarian, dan konsep interpretasi spesifik.

4. Melakukan evaluasi nilai berdasarkan: nilai-nilai yang berlaku di dalam kebudayaan dan masyarakat pendukung tarian; nilai-nilai khusus yang terkait dengan gaya dan genre, isi dan pesan tari; konsep-konsep spesifik tarian yang mencangkup efektivitas koreografi dan efektivitas pertunjukan.

Jika mencermati pernyataan di atas, maka langkah menganalisis pertunjukan tari terdiri atas dua tahap. Tahap pertama mencermati hal-hal yang berkaitan dengan "teks" atau pertunjukan tari: gerak, tari, koreografi, dan produksi pertunjukan.Tahap kedua mengenali "konteks" atau hal-hal yang berada di luar pertunjukam, tetapi ikut membangun makna dan menentukan keberhasilan pertunjukan bagi para pendukungnya yaitu seniman, pelaku maupun pemirsa dalam kaitan tempat dan kurun waktu serta hal-hal yang berkaitan sejarah aspek, budaya, sosial, politik, ekonomi, agama yang merupakan bekal penting untuk menginterpretasi dan menilai keberhasilan sebuah pertunjukan. 
Dalam kaitannya dengan pembahasan masalah tentang bagaimana estetika bentuk tari Lenggang Pari di Sanggar Seni Perwitasari Kelurahan Kemandungan Kecamatan Tegal Barat Kota Tegal maka digunakan langkah-langkah sebagai berikut:

1) Peneliti mengenali dan mendeskripsikan bentuk pertunjukan tari Lenggang Pari dengan melihat aspek pokok tari dan aspek pendukung tari antara lain gerak (tenaga, ruang, dan waktu), iringan, tata rias dan busana, tata lampu, tata suara, pelaku, tempat, waktu, properti. Elemen yang dideskripsikan adalah gerak, penari, aspek visual berupa wujud bentuk pertunjukan tari Lenggang Pari yang mengandung aspek pokok dan pendukung tarian, elemen-elemen auditif yaitu suatu gagasan atau ide yang dituangkan dan dapat dimunculkan gerak, suasana, karakter, ritme tari Lenggang Pari.

2) Peneliti mencoba mengetahui dan memahami hubungan antar komponen pertunjukan tari Lenggang Pari dilihat dari segi koreografi meliputi aspek pokok tari dan aspek pendukung tari. Hubungan itu adalah hubungan antar komponen gerak dengan tema, iringan rias busana. Dalam sub komponen gerak juga dicari hubungan antar elemen gerak, perjalanan ruang dan waktu: bentuk dan struktur koreografi.

3) Peneliti melakukan interpretasi berdasarkan konsep estetika tari dan nilai keindahan bentuk tari Lenggang Pari. Interpretasi dilakukan dengan cara memberi komentar penilaian keindahan terhadap gerak, iringan, rias wajah dengan busana, properti, tata lampu dan suara, tempat pertunjukan dan properti. 
Analisis data diawali dengan mengumpulkan seluruh data yang tersedia dari berbagai sumber, antara lain informasi dari narasumber yaitu pemilik sanggar seni Perwitasari, penari Lenggang Pari, pemusik, beberapa penikmat tari Lenggang Pari, dan Dinas Kebudayaan Kota Tegal. Data diperoleh melalui wawancara dan dokumentasi kemudian dianalisis lebih lanjut sesuai masalah yang diungkapkan dalam penelitian ini. Dari hasil data yang diperoleh tersebut maka hasil penelitian dianalisis secara tepat agar kesimpulan yang diperoleh juga tepat.

\subsection{Teknik Keabsahan Data}

Uji keabsahan data dalam penelitian, sering hanya ditekankan pada uji validitas dan reliabilitas. Validitas merupakan derajat ketepatan antara data yang terjadi pada obyek penelitian dengan daya yang dapat dilaporkan oleh peneliti. Sedangkan reliabilitas berkenaan dengan derajat konsistensi dan stabilitas data atau temuan. Dengan demikian data yang valid adalah data yang tidak berbeda antara data yang dilaporkan oleh peneliti dengan data yang sesungguhnya terjadi pada objek penelitian ( Sugiyono 2009: 267).

Penelitian mengenai Estetika Bentuk Pertunjukan Tari Lenggang Pari di Sanggar Seni Perwitasari Kelurahan Kemandungan Kecamatan Tegal Barat Kota Tegal menggunakan teknik keabsahan data dengan trianggulasi atau pembanding. Realita di lapangan beragam fenomena yang timbul, perbedaan dan persamaan harus selalu dideskripsikan, dicari argumentasinya dan selanjutnya dapat ditarik simpulan yang lemgkap dan lebih bisa diterima kebenarannya. dalam pengembangan validitas data pada penelitian kualitatif, peneliti perlu menggunakan cara trianggulasi untuk memperoleh derajad kepercayaan dan 
tingkat kebenaran tentang data dari lapangan (Maryono 2011: 113). Menurut Sugiyono (2009: 274) membedakan triangulasi menjadi tiga yaitu triangulasi sumber, triangulasi teknik, dan triangulasi waktu.

\subsubsection{Triangulasi Sumber}

Triangulasi sumber untuk menguji kredibilitas data dilakukan dengan cara mengecek data yang telah diperoleh melalui beberapa sumber. Hal itu dapat dicapai dengan jalan: 1) membandingkan data hasil pengamatan dengan data hasil wawancara; 2) membandingkan apa yang dikatakan orang di depan umum dengan apa yang dikatakan secara pribadi; 3) membandingkan apa yang dikatakan orangorang tentang situasi penelitian dengan apa yang dikatakan sepanjang waktu; 4) membandingkan keadaan dan perspektif seseorang dengan berbagai pendapat dan pandangan orang seperti rakyat biasa, orang yang berpendidikan menengah atau tinggi, orang berada, orang pemerintahan; 5) membandingkan hasil wawancara dengan isi suatu dokumen yang berkaitan.

Triangulasi sumber digunakan untuk menguji kredibilitas dan dilakukan dengan cara mengecek data yang diperoleh melalui beberapa sumber. Dengan triangulasi sumber data dapat dicapai dengan cara membandingkan data berupa bentuk pertunjukan tari Lenggang Pari yang telah disaksikan pada pertunjukan dengan wawancara dengan Ibu Damayanti dan Bapak Priambodo selaku penata gerak tari Lenggang Pari dan penari tari Lenggang Pari yaitu: Dimas, Zulfa, Wike, Putri tentang tari Lenggang Pari mengenai bentuk tari Lenggang Pari dan nilai keindahan bentuk tari Lenggang Pari. Kemudian membandingkan data hasil wawancara dengan dokumen yang telah ada, yaitu dokumen yang berupa video 
pertunjukan tari Lenggang Pari yang kemudian diulas kembali dengan penjelasan tentang bentuk tari Lenggang Pari dengan cara wawancara kepada pihak sumber primer yakni Ibu Damayanti dan Bapak Priambodo. Peneliti mengajukan pertanyaan yang mempunyai pokok masalah yaitu untuk mengetahui bentuk tari Lenggang Pari dan nilai keindahan bentuk tari Lenggang Pari untuk menggali kebenaran sumber data.

\subsubsection{Triangulasi Teknik}

Triangulasi teknik untuk menguji kredibilitas data dilakukan dengan cara mengecek data kepada sumber yang sama dengan teknik yang berbeda. Misalnya data diperoleh dengan wawancara, lalu dicek dengan observasi, dokumentasi atau kuesioner. bila dengan teknik pengujian kredibilitas tersebut menghasilkan data yang berbeda-beda, maka peneliti melakukan diskusi lebih lanjut kepada sumber data yang bersangkutan atau yang lain untuk memastikan data mana yang dianggap benar (Sugiyono 2008: 373).

Pada penelitian estetika bentuk pertunjukan tari Lenggang Pari triangulasi teknik digunakan oleh peneliti dengan cara melakukan pengecekan terhadap data yang diperoleh yaitu tentang bentuk tari Lenggang Pari dan nilai keindahan bentuk tari Lenggang Pari dengan melihat beberapa dokumentasi yang ada dan kemudian dihubungkan atau dibandingkan dengan metode yang sama, maka untuk menemukan kebenarannya didukung dari hasil observasi, wawancara dan dokumentasi. Dari hasil observasi, wawancara dan dokumentasi dalam bentuk pertunjukan tari Lenggang Pari diperoleh data dilapangan yaitu tentang gerak, penari, iringan, tema, tata rias, tata busana, properti, pola lantai, tata pentas, tata 
lampu danpenonton. Keseluruhan dari bentuk pertunjukan tersebut dapat dianalisis berdasarkan bentuk tari Lenggang Pari dan nilai keindahan bentuk tari Lenggang Pari.

\subsubsection{Triangulasi Waktu}

Triangulasi waktu dilakukan dengan cara melakukan pengecekan dengan wawancara, observasi atau teknik lain dalam waktu atau situasi berbeda. Bila hasil uji menghasilkan data yang berbeda, maka dilakukan secara berulang-ulang sehingga sampai ditemukannya kepastian data.

Waktu juga sering mempengaruhi kredibilitas data. Data yang dikumpulkan dengan wawancara di pagi hari saat narasumber masih segar, belum banyak kegiatan yang menimbulkan berbagai macam permasalahan, akan memberikan data yang lebih valid sehingga lebih kredibel. Waktu yang dipilih oleh peneliti dapat menimbulkan perbedaan dalam membandingkan dan melakukan pengecekan data yang diperoleh di lapangan mengenai estetika bentuk pertunjukan tari Lenggang Pari. Hal ini dalam rangka pengujian kredibilitas data dapat dilakukan dengan cara melakukan pengecekan dengan wawancara, observasi atau teknik lain dalam waktu dan situasi yang berbeda. Bila hasil uji menghasilkan data yang berbeda, maka dilakukan secara berulang-ulang sehingga sampai ditemukan kepastian datanya. 


\section{BAB IV}

\section{HASIL DAN PEMBAHASAN}

\subsection{Gambaran Umum Lokasi Penelitian}

Lokasi penelitian estetika bentuk pertunjukan tari Lenggang Pari di Sanggar Seni Perwitasari Kelurahan Kemandungan Kecamatan Tegal Barat Kota Tegal. Lokasi penelitian ini mempunyai letak, kondisi geografis dan demografis sebagai berikut:

\subsubsection{Letak Geografis Lokasi Penelitian}

Kelurahan Kemandungan merupakan salah satu kelurahan dari tujuh kelurahan yang ada di Kecamatan Tegal Barat Kota Tegal. Kelurahan Kemandungan merupakan daerah dataran rendah dengan ketinggian 1 meter di atas permukaan laut, dekat dengan daerah pantai. Kelurahan Kemandungan terbagi menjadi 3 RW yaitu RW 1 terdiri dari 4 RT, RW 2 terdiri dari 6 RT, dan RW 3 terdiri dari 3 RT. Kelurahan Kemandungan memiliki luas 67,747 ha yang terdiri dari 3 RW 13 RT dengan batas wilayah sebagai berikut:

$\begin{array}{ll}\text { Sebelah Utara } & : \text { Kelurahan Kraton dan Pekauman } \\ \text { Sebelah Selatan } & : \text { Kelurahan Debong Lor } \\ \text { Sebelah Timur } & : \text { Kelurahan Pekauman dan Randugunting } \\ \text { Sebelah Barat } & : \text { Kelurahan Pesurungan Kidul }\end{array}$

Letak objek penelitian tari Lenggang Pari terletak di Jalan Sukardi No.32 Rt 03 Rw 01 Kelurahan Kemandungan Kecamatan Tegal Barat Kota Tegal. Sanggar Seni Perwitasari ini berada dekat dengan pusat kota dan berada dekat dengan beberapa sekolah yaitu SD Negeri Kemandungan 4, UNNES PGSD Kota 
Tegal, SMK Bhakti Karya Kota Tegal. Sanggar Seni Pewitasari berada di pusat perkantoran dan Pasar Modern seperti Rita Mall, Transmart Tegal, Pacific Mall. Jarak Sanggar Seni Perwitasari ke pusat pemerintahan Kelurahan 200 meter, ke pusat Kota Tegal $2 \mathrm{~km}$, dan ke pusat pemerintahan Kecamatan $1 \mathrm{~km}$. Letak Sanggar Seni Perwitasari berada di rumah pribadi milik Ibu Damayanti dan Bapak Priambodo. Sanggar ini memanfaatkan sedikit ruangan di halaman rumah sebagai tempat berlatih. Masyarakat sekitar menanggapi positif dengan adanya sanggar di lingkungan yang mayoritas penduduknya bekerja sebagai buruh industri, PNS dan wiraswasta.

\subsubsection{Kondisi Fisik Wilayah}

Perjalanan menuju lokasi Sanggar Seni Perwitasari di Kelurahan Kemandungan Kecamatan Tegal Barat Kota Tegal dapat ditempuh dengan kendaraan pribadi dengan waktu tempuh sekitar 15 menit dari pusat Kota Tegal. Untuk menuju ke Sanggar Seni Perwitasari dapat menggunakan kendaraan pribadi maupun kendaraan umum, hal ini dikarenakan karena akses transportasi di daerah tersebut sudah sangat memadai. Jalan menuju ke Sanggar Seni Perwitasari Kelurahan Kemandungan Kecamatan Tegal Barat Kota Tegal ini dipenuhi banyak perkantoran dan pasar modern. Sebagian besar wilayah Kelurahan Kemandungan merupakan perumahan, kantor, perusahaan yang memiliki luas 61,747 Ha. Kelurahan Kemandungan Kecamatan Tegal Barat Kota Tegal merupakan daerah jasa dan perkantoran. 


\subsubsection{Kependudukan}

Jumlah penduduk Kelurahan Kemandungan sampai dengan Desember tahun 2016 berjumlah 1.126 KK. Total jumlah penduduk Kelurahan Kemandungan sebanyak 3.681 jiwa, terdiri dari 1.815 jiwa penduduk laki-laki dan 1.866 jiwa penduduk perempuan. Adapun klasifikasi jumlah penduduk menurut kelompok umur, mata pencaharian, tingkat pendidikan dan jumlah fasilitas umum yang ada di Kelurahan Kemandungan dapat dilihat pada tabel berikut:

Tabel 4.1 Jumlah Penduduk Menurut Umur

\begin{tabular}{|c|c|c|c|c|}
\hline No. & Umur & Laki-laki & Perempuan & Jumlah \\
\hline 1. & $0-4$ & 156 & 146 & 302 \\
2. & $5-9$ & 150 & 141 & 291 \\
3. & $10-14$ & 128 & 127 & 255 \\
4. & $15-19$ & 137 & 116 & 253 \\
5. & $20-24$ & 120 & 113 & 233 \\
6. & $25-29$ & 93 & 117 & 210 \\
7. & $30-39$ & 178 & 225 & 403 \\
8. & $40-49$ & 221 & 231 & 452 \\
9. & $50-59$ & 195 & 205 & 400 \\
10. & $60+$ & 437 & 445 & 882 \\
\hline
\end{tabular}

Sumber: Profil Kelurahan Kemandungan Tahun 2017

Berdasarkan tabel 4.1 menunjukan bahwa jumlah penduduk Kelurahan

Kemandungan menurut kelompok umur adalah bervariasi. Berdasarkan tabel 
tersebut menunjukan hubungan antara pertunjukan Tari Lenggang Pari dengan jumlah penduduk berdasarkan kelompok umur ditunjukan pada rentang umur 15 24 tahun. Usia penari tari Lenggang Pari antara 15-19 tahun termasuk usia remaja berjumlah sekitar 10 orang. Usia 20-24 tahun termasuk usia tahap pendewasaan berjumlah 15 orang, pada usia tahap pendewasaan ini memiliki kemampuan bekerjasama yang baik dengan tingkat kesadaran dan pembawaan diri cukup baik. Berdasarkan wawancara dengan Ibu Yanti tanggal 9 April 2017, hal ini amat penting dalam pembelajaran dan perkembangan tari Lenggang Pari hingga tujuan dan maksud tarian dapat tersampaikan dengan baik.

Tabel 4.2 Jumlah Penduduk Menurut Agama

\begin{tabular}{|c|l|c|}
\hline No. & \multicolumn{1}{|c|}{ Agama } & Jumlah \\
\hline 1. & Islam & 3.287 orang \\
\hline 2. & Kristen Katholik & 139 orang \\
\hline 3. & Kristen Protestan & 152 orang \\
\hline 4. & Budha & 85 orang \\
\hline 5. & Hindu & 14 orang \\
\hline 6. & Khong Hucu Jumlah & orang \\
\hline
\end{tabular}

Sumber: Profil Kelurahan Kemandungan Tahun 2017

Berdasarkan tabel 4.2 dapat diketahui bahwa penduduk Kelurahan Kemandungan terbagi dalam beberapa agama seperti Islam, Kristen Katholik, Kristen Protestan, Budha, Hindu, Khong Hucu. Mayoritas penduduk Kelurahan Kemandungan menganut agama islam dengan jumlah total 3.287 jiwa. 
Keberagaman ajaran agama tersebut tidak terlalu berpengaruh besar terhadap pertunjukan Tari Lenggang Pari, semua penari tetap disiplin menjalankan kewajiban sesuai dengan ajaran agama nya masing-masing sebagai ungkapan rasa syukur atas karunia Tuhan dengan penuh khikmat agar senantiasa dalam melakukan aktifitas berjalan dengan lancar.

Tabel 4.3 Jumlah Penduduk Menurut Mata Pencaharian

\begin{tabular}{|c|l|c|}
\hline No. & \multicolumn{1}{|c|}{ Mata Pencaharian } & Jumlah \\
\hline 1. & Petani sendiri & Orang \\
\hline 2. & Buruh tani & Orang \\
\hline 3. & Nelayan & 50 orang \\
\hline 4. & Pengusaha & 204 orang \\
\hline 5. & Buruh industri & 333 orang \\
\hline 6. & Buruh bangunan & 348 orang \\
\hline 7. & Pedagang & 153 orang \\
\hline 8. & Jasa angkutan & 301 orang \\
\hline 9. & PNS / TNI / POLRI & 85 orang \\
\hline 10. & Pensiunan & 2.043 orang \\
\hline 11. & Lainnya & $\mathbf{3 . 6 8 1}$ orang \\
\hline & & \\
\hline
\end{tabular}

Sumber: Profil Kelurahan Kemandungan Tahun 2017

Berdasarkan tabel 4.3 menunjukan bahwa mata pencaharian penduduk Kelurahan Kemandungan sebagian besar adalah Pedagang, Buruh Bangunan dan PNS / TNI / POLRI. Hal ini tidak berkaitan dengan pertunjukan tari Lenggang 
Pari karena mayoritas penarinya masih menempuh pendidikan baik di jengjang menengah atas maupun perguruan tinggi, meskipun ada beberapa penari yang sudah bekerja baik dibidang pedagang dan lain sebagainya.

Tabel 4.4 Jumlah Penduduk Menurut Tingkat Pendidikan

\begin{tabular}{|c|l|c|}
\hline No. & \multicolumn{1}{|c|}{ Pendidikan } & Jumlah \\
\hline 1. & Tamat Akademi/Peruruan Tinggi & 398 orang \\
\hline 2. & Tamatan SLTA & 921 orang \\
\hline 3. & Tamatan SLTP & 705 orang \\
\hline 4. & Tamatan SD/MI & 538 orang \\
\hline 5. & Tidak Tamat SD & 369 orang \\
\hline 6. & Belum Tamat SD & 662 orang \\
\hline 7. & Tidak Sekolah/Belum Sekolah & 88 orang \\
\hline \multicolumn{2}{|c|}{ Jumlah } & 3.681 orang \\
\hline
\end{tabular}

Sumber: Profil Kelurahan Kemandungan Tahun 2017

Berdasarkan tabel 4.4 dapat disimpulkan bahwa tingkat pendidikan masyarakat Kelurahan Kemandungan Kecamatan Tegal Barat Kota Tegal tergolong cukup tinggi. Hal ini dibuktikan dengan jumlah lulusan tingkat SLTA yang cukup banyak yaitu berjumlah 921 orang. Kenyataan yang ditemui peneliti di lapangan menunjukan sebagian besar penari adalah siswa SMA dan Perguruan Tinggi serta tamatan SLTA. Sebanyak 10 penari merupakan mahasiswa aktif di perguruan tinggi, 10 penari masih menempuh pendidikan menegah atas, dan 5 orang penari sudah bekerja. Pada saat pertunjukan tari Lenggang Pari mayoritas diminati oleh hampir seluruh lapisan masyarakat dengan tingkat pendidikan 
menyeluruh dari tingkat pendidikan rendah sampai perguruan tinggi. Kerja keras, kerja sama, kekeluargaan, semangat yang membara, keahlian atau bakat serta minat penari dalam mempelajari dan bergabung bersama-sama dari berbagai elemen pendidikan inilah yang membuat tari Lenggang Pari berkembang. Apresiasi masyarakat dari kalangan petani hingga pejabat daerah setempat yang ditunjukan dengan perasaan senang akan memberikan motivasi dan kekuatan baru bagi penari untuk tetap melestarikan kebudayaan.

Tabel 4.5 Jumlah Fasilitas Umum

\begin{tabular}{|c|c|c|}
\hline No. & Nama Fasilitas & Jumlah \\
\hline 1. & Masjid & 2 \\
\hline 2. & Mushola & 6 \\
\hline 3. & Pasar modern & 1 \\
\hline 4. & Lapangan Olahraga & 1 \\
\hline 5. & PAUD & 2 \\
\hline 6. & Taman Kanak-Kanak (TK) & 2 \\
\hline 7. & SD/MI & 5 \\
\hline 8. & SMA/SMK/MA & 1 \\
\hline 9. & Perguruan Tinggi & 1 \\
\hline 10. & Posyandu & 3 \\
\hline 11. & Puskesmas & 1 \\
\hline 12. & Klinik Bersalin & 3 \\
\hline 13. & Rumah Sakit & 1 \\
\hline 14. & TP PKK & 1 \\
\hline
\end{tabular}




\begin{tabular}{|c|l|c|}
\hline 15. & Karang Taruna “Mekar” & 1 \\
\hline 16. & BKM "Mutiara Artha” & 1 \\
\hline 17. & Wartekkel & 1 \\
\hline
\end{tabular}

Sumber: Profil Kelurahan Kemandungan Tahun 2017

Tabel 4.5 di atas menunjukan bahwa jumlah fasilitas umum yang paling banyak adalah mushola sebagai sarana tempat ibadah. Namun sarana dan prasarana yang berhubungan dengan tari Lenggang Pari adalah sarana yang dapat digunakan sebagai tempat latihan. Beberapa fasilitas yang memungkinkan dapat digunakan sebagai sarana tempat latihan adalah lapangan olahraga, karang taruna, PAUD, SD, SMK, UNNES PGSD. Gedung tersebut dapat digunakan sebagai tempat latihan karena tempat-tempat tersebut cukup luas untuk latihan para penari akan tetapi Sanggar Seni Perwitasari menggunakan fasilitas umum milik kota Tegal yaitu Pendopo Ki Gede Sebayu sebagai tempat latihan. Sarana dan Prasarana yang ada dapat membantu memperlancar latihan yang dilakukan menjelang pertunjukan.

\subsection{Sanggar Seni Perwitasari}

Sanggar Seni Perwitasari yang beralamat di Jalan Sukardi No.32 Rt 03 Rw

01 Kelurahan Kemandungan Kecamatan Tegal Barat Kota Tegal merupakan lokasi penelitian tari Lenggang Pari. Sanggar Seni Perwitasari berdiri sejak tahun 2002 dan sudah mendapatkan pengakuan serta pengesahan dari pemerintah Kota Tegal. Sanggar Seni Perwitasari dipimpin dan dikelola oleh Bapak Priambodo dan Ibu Damayanti yang juga menggeluti bidang seni terutama tari. Awalnya sanggar 
ini dibuat karena dorongan kedua orang tua Pak Pri, dengan tujuan untuk pelestarian kebudayaan terutama seni tari.

Perwitasari diambil dari nama air suci yang abadi sebagai filosofi dalam penamaan sanggar dengan maksud supaya ilmu yang disampaikan kepada anak didik dapat menjadi sumber penghidupan yang bermanfaat dan berlangsung lama. Wawancara dengan Bapak Priambodo tanggal 9 April 2017, sebagai berikut:

“.....Awal pertama kali berdiri itu belum ada murid, untuk pendanaan kita memulai nya dari menari berdua mba mewakili Kota Tegal. Pada tahun 2003 mulai tetaangga kanan kiri ada yang ingin ikut, murid-murid dari sekolah-sekolah yang saya dan Bu Yanti bina yang memang punya talenta khusus kita gabungkan ke sanggar. Pada saat ada kegiatan-kegiatan tertentu dari murid sanggar kita libatkan sebagai kepengurusan didalamnya. Didalam perkembangannya walaupun kami mengalami pasang surut keanggotaan karna kami pijakannya tidak dimateri jadi, alhamdulillah sanggar seni perwitasari bisa eksis sampai sekarang dengan modal itu tadi berniat kebersamaan untuk belajar. Karena tujuan utama kami mendirikan sanggar ini untuk pelestarian kebudayaan. Dengan sukarela kami berdua berfikir shodakoh ilmu mudah-mudahan ilmu itu bermanfaat dan pelestarian kebudayaan jawa agar tidak punah....."

Sanggar Seni Perwitasari aktif digunakan untuk berlatih tari khususnya tari jawa. Jadwal latihan rutin di Sanggar Seni Perwitasari dilakukan pada hari Minggu sore mulai pukul 15.00 - 17.00 bertempat di Pendopo Ki Gede Sebayu Kota Tegal. Sejak banyaknya murid yang berlatih di Sanggar Seni Perwitasari maka tempat latihan dialihkan ke Pendopo Ki Gede Sebayu yang berada di lingkungan kantor walikota Tegal. Hal ini merupakan wujud apresiasi dan sambutan yang baik dari pemerintah Kota Tegal terhadap Sanggar Seni Perwitasari. Siswa yang belajar berlatih tari di Sanggar Seni Perwitasari terdiri dari berbagai kalangan tingkat pendidikan dan usia serta kemampuan menari. Ada siswa yang memang benar-benar dari dasar berlatih menari, ada juga siswa yang 
memang sudah mempunyai bakat dan tetap belajar menari secara bersama-sama dari gerakan dasar sampai dapat mengembangkan. Latihan dasar pada Sanggar Seni Perwitasari biasanya diberikan injeksi berupa olah tubuh selama 1 jam pertemuan. Materi yang diberikan disesuaikan dengan usia siswa, akan tetapi semua siswa wajib mendapatkan latihan gerak dasar tari jawa seperti pengenalan ragam gerak dasar tangan, ragam gerak dasar kaki, tolehan dan sikap mendhak pada tari Jawa.

Siswa yang berlatih menari di Sanggar Seni Perwitasari diberikan pemahaman tentang gerakan dasar menari pada tari Jawa sebagai bekal pengetahuan dan kelancaran pada materi berikutnya. Siswa siswi ini berasal dari anak-anak binaan Ibu Damayanti dan Bapak Priambodo di sekolah formal, dari tingkat Taman Kanak-Kanak sampai Perguruan Tinggi, berawal mula dari itu sekarang jumlah siswa yang aktif latihan menari mencapai 50 orang. Siswa yang mengikuti latihan di Sanggar Seni Perwitasari ini berasal dari tingkat pemula, lanjut dan mahir. Pembagian kelas menari berdasarkan usia dan kemampuan diri siswa tersebut. Pada kelas pemula lebih mendetail diberikan latihan fisik dan kekuatan otot melalui olah tubuh. Pengenalan ragam gerak dasar tari Jawa secara bertahap dan dalam satu rangkaian. Siswa juga dilatih kepekaan iringan dengan cara menstimulasi siswa dengan mengenalkan dan mendengarkan musik iringan tari. Siswa diberikan latihan ragam gerak dasar tari Jawa dengan mengenal ragam gerakan dan mempraktikanya secara bertahap, kemudian dirangkai menjadi satu rangkaian gerak tari dengan diberikan materi tari kreasi dolanan seperti Suwe Ora Jamu yang gerakannya sudah dibuat oleh penata tari sebagai pelatih. Untuk kelas 
lanjut dan mahir mulai diberikan tarian yang memang khusus diciptakan oleh Ibu Damayanti dan Bapak Priambodo sebagai materi ajar di Sanggar Seni Perwitasari yang nantinya diharapkan mampu dikembangkan oleh siswanya sebagai modal mengajar menari. Selain tarian khusus tersebut siswa di Sanggar Seni Perwitasari juga diajarkan tari bentuk tari kreasi Jawa, tari Klasik Jawa seperti tari Topeng Endel, Tari Gambyong, Gagahan Putra, Jemparingan, tari Golek dan tari Gambyong. Siswa juga diajarkan tarian yang diciptakan khusus oleh Ibu Damayanti dan Bapak Priambodo,diantaranya; tari Bedayan Mendhung, tari Bedayan Pancasakti, tari Giyul Bahari, tari Srimpen Dharmasetra, tari Panca Kusuma, tari Bedayan Dipa Arimurcitta, tari Lengger, tari Jaipong Pancasakti dan tari Ambu Sakanti. Selain tarian bentuk siswa juga dilatih untuk berkreatifitas dan mengembangkan gerak-gerak dasar tarian sesuai dengan daya imajinasi masingmasing siswa.

Sanggar Seni Perwitasari juga memfasilitasi penyewaan kostum tari, makeup dalam berbagai acara. Hasil latihan menari di Sanggar Seni Perwitasari sangat baik, hal ini didukung oleh niat siswa dalam berlatih dan keseriusannya. Selain itu daya kreatifitas penata tari dalam menciptakan tarian seperti pada Tari Lenggang Pari. Tari Lenggang Pari sudah sering ditampilkan diberbagai acara dan diberbagai tempat seperti di Cirebon \& Brebes pada acara Panen Raya Nasional Padi MSP, di Pendopo Ki Gede Sebayu dalam acara Pembukaan Piala Gubernur Jawa Tengah, di Taman Rakyat Slawi dalam acara HUT Kabupaten Tegal 2016, di Universitas Pancasakti Tegal dalam acara Seminar Nasional dan Peluncuran 
Kamus Bahasa Jawa Tegal, dan pada acara HUT BNI yang mewakili BNI cabang Kota Tegal di Solo dan Semarang pada tahun 2016.

Berikut foto 4.1 adalah Lokasi Sanggar Seni Perwitasari

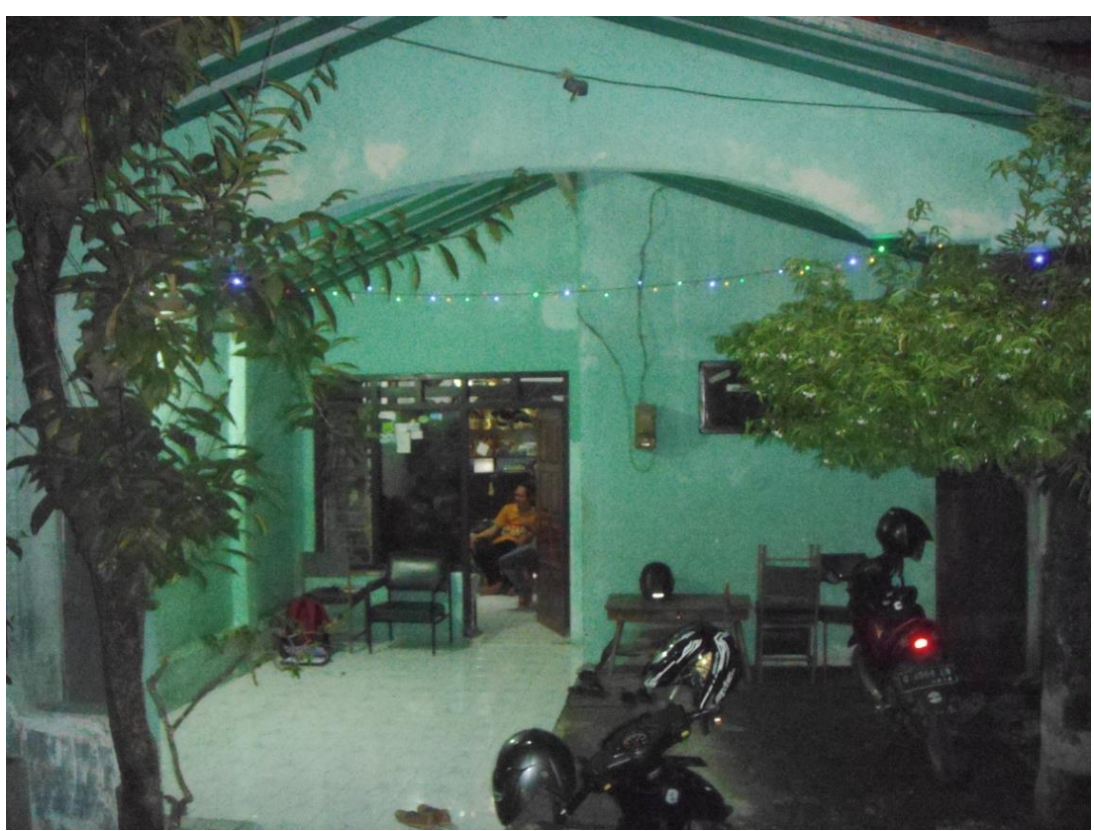

Foto 4.1 Lokasi Sanggar Seni Perwitasari (Sumber: Devvi Lutfiana, 24 April 2017)

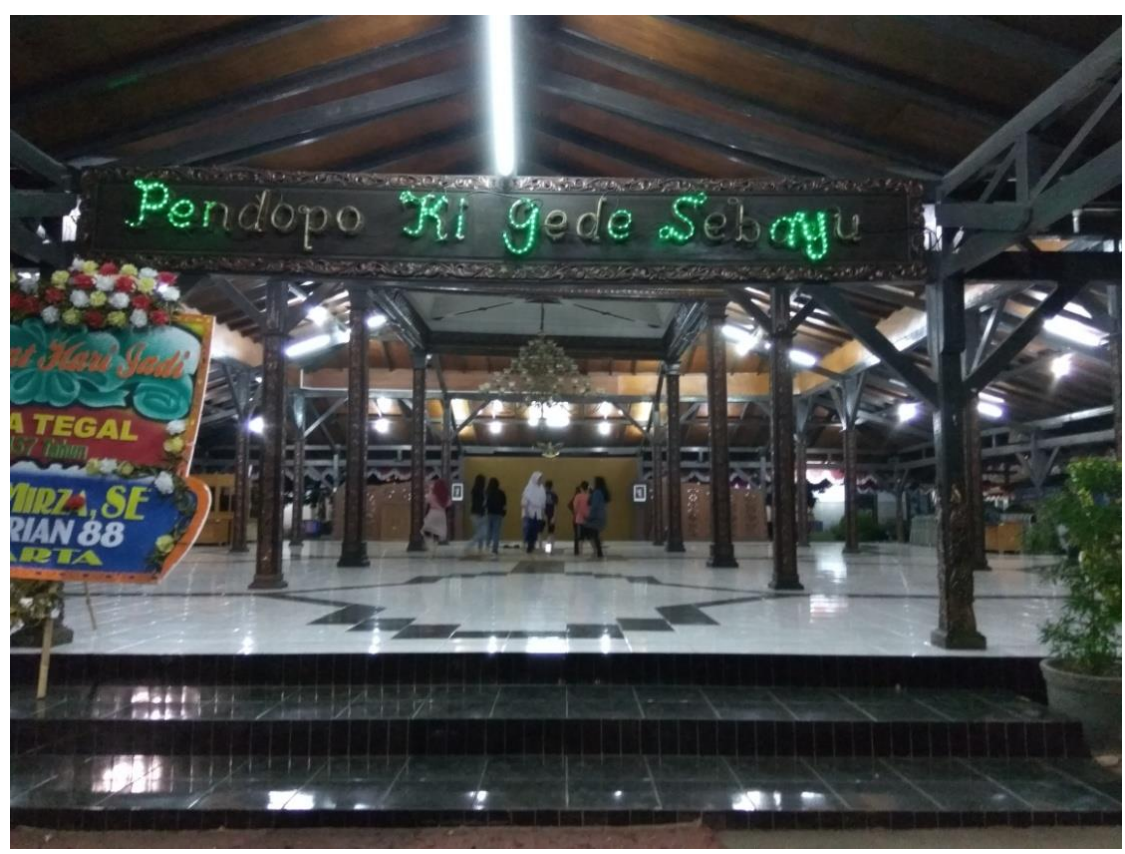

Foto 4.2 Tempat Berlatih Tari (Sumber: Devvi Lutfiana, 15 Mei 2017) 


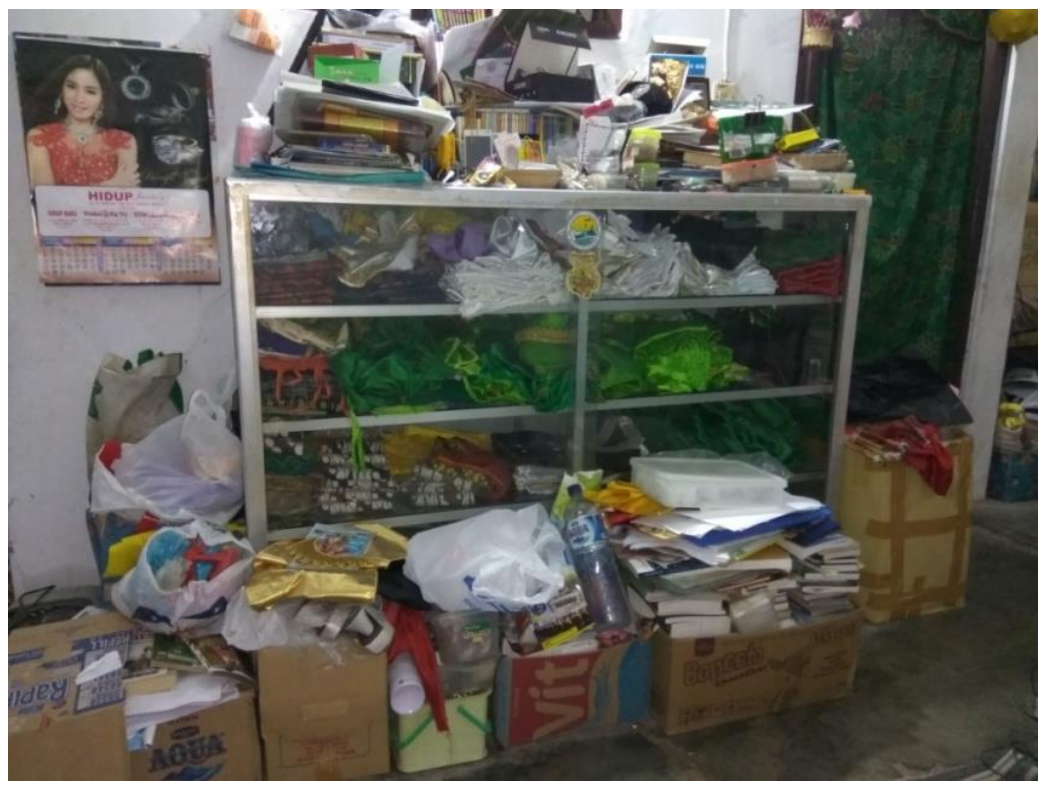

Foto 4.3 Tempat Kostum

(Sumber: Devvi Lutfiana, 24 April 2017)

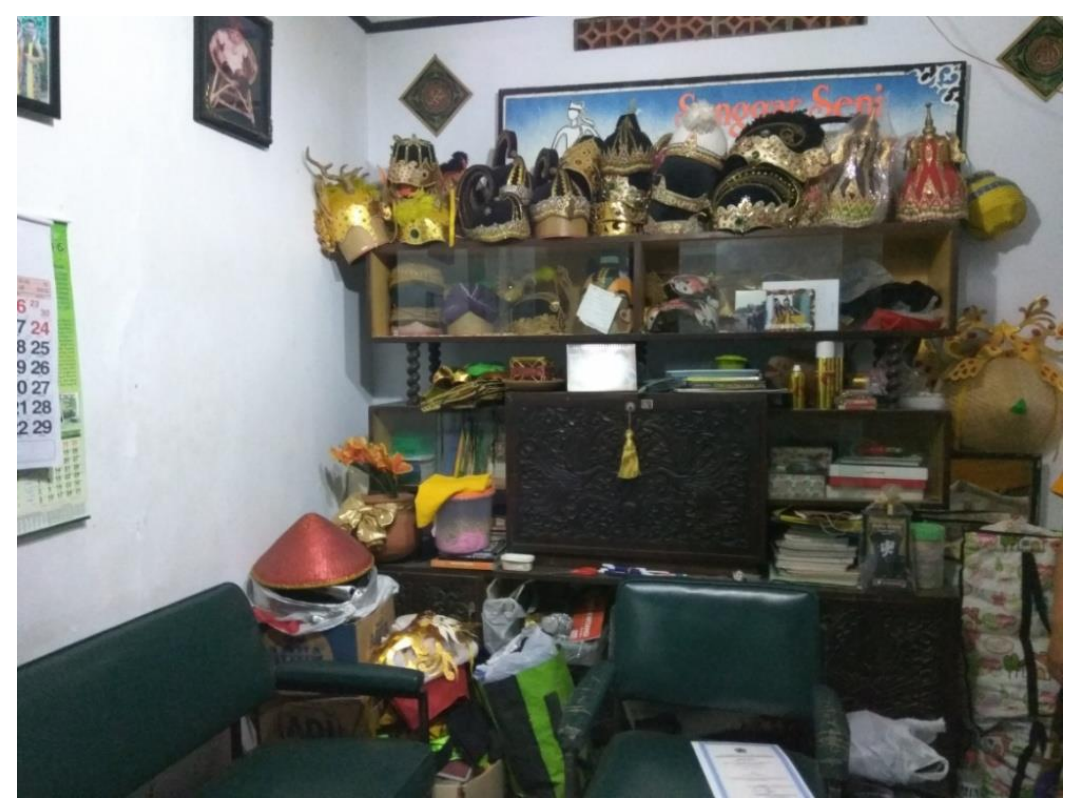

Foto 4.4 Tempat Kostum

(Sumber: Devvi Lutfiana, 24 April 2017)

\subsection{Latar Belakang Tari Lenggang Pari}

Tari Lenggang Pari adalah sebuah tarian kreasi baru yang diciptakan pada akhir bulan November tahun 2015 oleh Ibu Damayanti. Tari Lenggang Pari terinspirasi dari panen raya padi MSP seluruh Indonesia yang diadakan di Kota 
Cirebon. Tari Lenggang Pari merupakan tarian putri yang ditarikan secara berkelompok dan kemudian dikembangan menjadi tarian pasangan putra dan putri. Awal mula perkembangannya dikarenakan kostum tari Lenggang Pari berupa warna merah dan putih yang melambangkan suatu kesuburan dalam kehidupan masyarakat. Warna merah dalam tari Lenggang Pari berarti suci, sedangkan warna putih adalah hidup atau nyawa. Warna meerah menjadi perlambangan benih ibu yang membutuhkan pasangan untuk menyempurnakan suatu simbol kesuburan dengan adanya perwujudan warna putih yang melambangkan benih bapak (Wawancara, Sri Damayanti 9 April 2017).

Tari Lenggang Pari merupakan komposisi tari berpasangan putra dan putri. Tari berpasangan ini merupakan bentuk tari kerakyatan yang disajikan untuk menghibur penonton. Tarian ini menggambarkan aktifitas bercocok tanam pada masyarakat yang bekerja sebagai petani. Lenggang dalam tarian ini diartikan sebagai aktifitas masyarakat dalam bertani, tari Lenggang Pari disajikan oleh penari putra dan putri sebagai wujud dari lambang kesuburan yang berkaitan erat dengan kemakmuran masyarakat melalui hasil panen padi MSP yang berlimpah. Tari Lenggang Pari merupakan ekspresi jiwa, konsep, atau gagasan seniman pelakunya (penari dan musisi) yang diungkapkan dengan bentuk pola pengaturan ritme gerak dan pola ruang secara berpasangan oleh penarinya. Tari Lenggang Pari dapat dikategorikan sebagai tari tradisional kerakyatan.

Tari Lenggang Pari termasuk tari kreasi yang masih berpijak pada gerak tari tradisi gaya surakarta dan tegalan, gerak-gerak tari Topeng yang sudah diperhalus yang sudah dikembangkan dan dikreasikan menjadi rangkaian gerak 
yang indah hingga akhirnya menjadi suatu tarian. Beberapa gerakan yang khas pada tari Lenggang Pari memiliki nama ragam, yaitu seperti Lumaksono Ngracik, Nandur, Nampi, Ngani-ani dan Dewi-dewian (Wawancara, Sri Damayanti 6 Juni 2017).

\subsection{Bentuk Pertunjukan Tari Lenggang Pari di Sanggar Seni Perwitasari Kelurahan Kemandungan Kecamatan Tegal Barat Kota Tegal}

Bentuk pertunjukan tari Lenggang Pari dapat dilihat melalui pola pertunjukan dan elemen-elemen pertunjukannya seperti tema, alur cerita/alur dramatik, gerak, penari, pola lantai, ekspresi wajah/polatan, tata rias, tata busana, iringan/musik, setting panggung, properti dan pencahayaan. Unsur-unsur tersebut dapat dijelaskan sebagai berikut.

\subsubsection{Pola Pertunjukan Tari Lenggang Pari di Sanggar Seni Perwitasari Kelurahan Kemandungan Kecamatan Tegal Barat Kota Tegal}

Pola pertunjukan tari Lenggang Pari terbagi menjadi tiga bagian, yaitu bagian awal, bagian inti, dan bagian akhir. Berikut uraian penjelasan pola pertunjukan tari Lenggang Pari:

\subsubsection{Bagian Awal Pertunjukan}

Bagian awal dari tari Lenggang Pari ditandai dengan ilustrasi musik suara burung yang menggambarkan suasana ladang yang berkaitan erat dengan petani. Penari putra memasuki area panggung dengan gerakan membungkukan badan sambil berlari kecil dan memegang caping menggambarkan persiapan petani untuk menuju ke sawah. Kemudian tanda dimulainya jalan masuk penari putri ke area panggung ditandai dengan perubahan musik dari ilustrasi ke tembang. Penari 
mulai memasuki area panggung dengan gerakan Lumaksono ngracik dengan mengayunkan kedua tangan secara bergantian dan dimulai dari tangan kanan terlebih dahulu. Kemudian dilanjutkan dengan ragam gerak Penghubung dan Srisig.

\subsubsection{Bagian Inti Pertunjukan}

Bagian inti pertunjukan tari Lenggang Pari dimulai saat penari putra dan putri berada di atas panggung. Penari mulai menarikan tari Lenggang Pari dengan alunan musik yang bersenandung. Bagian inti dari pertunjukan tari Lenggang Pari dimulai ketika penari putra dan putri menarikan tarian dengan ragam gerak Nandur dan mulai memainkan properti dalam menari. Penari menarikan tari Lenggang Pari secara utuh dari ragam gerak Nandur, Ngusir Manuk, Ngasoh, Nampi, Mupuk Siram, Lembehan Leyeh, Ngani-ani, Dewi-dewian, dan Ndheplok. Pada bagian ini merupakan penggambaran dari kegiatan bertani dari menanam padi hingga memanen.

\subsubsection{Bagian Akhir Pertunjukan}

Bagian akhir dari pertunjukan tari Lenggang Pari ditandai pada saat penari putri melakukan gerakan Lembehan Putri dan penari putra melakukan gerakan yang menggambarkan kegembiraan hasil panen dengan iringan yang diikuti tembang “tok..tek..tok..tok..dung..tok..tok...tek...tok..dung..tok.......”. Penari putra dan putri melenggang secara berpasangan yang menunjukan kegembiraan petani atas hasil panen padi yang berlimpah dan diakhiri dengan pose meletakkan caping disisi kanan penari sampai iringan musik selesai. 


\subsubsection{Elemen Pertunjukan Tari Lenggang Pari di Sanggar Seni Perwitasari Kelurahan Kemandungan Kecamatan Tegal Barat Kota Tegal}

\subsubsection{Tema}

Tema dalam pertunjukan tari Lenggang Pari yaitu lingkungan dengan menggambarkan aktifitas kehidupan petani sebagai pahlawan dalam kehidupan masyarakat. Nilai-nilai kehidupan yang dapat diperoleh dari pertunjukan tari Lenggang Pari yaitu nilai perjuangan, kebersamaan, keteladanan, kegotongroyongan, bekerja keras, sifat bersyukur dan nilai kebahagiaan. Tema yang diambil dalam pertunjukan tari Lenggang Pari diperoleh dari hasil observasi secara langsung penata tari dengan masyarakat yang bekerja sebagai petani, menikmati suasana persawahan dan kehidupan petani. Hal ini sangat berpengaruh pada kualitas tari Lenggang Pari. Garapan yang matang pada tari Lenggang Pari dapat menyampaikan pesan-pesan yang terkandung dalam tarian secara utuh dan dapat diterima oleh penonton. Keutuhan tersebut mampu memiliki nilai estetik sehingga maksud dan tujuan dari tema tersebut mampu tersampaikan kepada penonton, sehingga nilai-nilai perjuangan, kebersamaan, keteladanan, kegotongroyongan, bekerja keras, sifat bersyukur dan nilai kebahagiaan akan benar-benar dinikmati dan dirasakan oleh penonton.

\subsubsection{Alur cerita/alur dramatik}

Pertunjukan tari Lenggang Pari menggunakan alur cerita atau alur dramatik yang dihasilkan dari cerita kehidupan masyarakat yang mempunyai pekerjaan sebagai petani. Cerita yang diangkat dalam pertunjukan tari Lenggang Pari merupakan kegiatan aktifitas sehari-hari petani. Kegiatan bertani dari 
persiapan berangkat ke sawah, menanam, memupuk, mengairi dan memanen padi. Nilai estetis pertunjukan tari Lenggang Pari dari segi alur cerita nampak dari cerita rangkaian kegiatan bertani yang diwujudkan melalui gerak-gerak tari. Alur cerita tersebut dirangkai secara utuh dalam rangkaian gerak tari, iringan, rias busana dan properti.

\subsubsection{Gerak}

Gerak merupakan aspek pokok dalam pertunjukan tari Lenggang Pari. Gerak-gerak dalam tari Lenggang Pari diperoleh dari kegiatan observasi, eksplorasi, improvisasi dan komposisi oleh penata tari. Gerak pada tari Lenggang Pari berpijak pada tari kerakyatan gaya surakarta. Bentuk gerak tari Lenggang Pari menggunakan gerak-gerak kerakyatan yang sederhana dan merupakan kreatifitas gerakan kehidupan petani yang telah dikembangkan dan dirangkai dalam bentuk tarian.

Tari Lenggang Pari memiliki perincian gerak yang dapat dilihat melalui unsur ragam gerak Tari Lenggang Pari dan deskripsi gerak tari Lenggang Pari. Unsur ragam gerak tersebut meliputi ragam gerak kepala, tangan, kaki dan badan. Elemen tubuh tersebut dapat diuraikan ke dalam sikap dan unsur gerak dalam tari dan dirangkai secara utuh menjadi tari Lenggang Pari yang memiliki sifat gerak lincah, dinamis, atraktif dan energik. Bentuk dari tarian ini merupakan interaksi penari putra dan penari putri. Keberadaan penari putra dan putri menunjukan kebersamaan, rasa saling tolong menolong dan kerukunan sesuai dengan konsep yang dirancang koreografer. 


\subsection{Deskripsi Ragam Gerak Tari Lenggang Pari}

Berikut ini adalah tabel deskripsi ragam gerak tari Lenggang Pari yang dapat diuraikan dari nama ragam gerak, deskripsi ragam gerak, keterangan hitungan atau ketukan gerak dan gambar foto sikap dari masing-masing ragam gerak tari Lenggang Pari.

Tabel 4.6 Deskripsi Ragam Gerak Tari Lenggang Pari

\begin{tabular}{|c|c|c|c|c|c|}
\hline No. & $\begin{array}{c}\text { Nama } \\
\text { Ragam }\end{array}$ & Hitungan & $\begin{array}{c}\text { Deskripsi Ragam } \\
\text { Gerak }\end{array}$ & Keterangan & Pola Lantai \\
\hline 1. & $\begin{array}{l}\text { Lumaksono } \\
\text { Ngracik }\end{array}$ & $\begin{array}{l}6 \text { x } 8 \text { hitungan } \\
\text { terdiri dari: } \\
1 \text { - } 8 \\
\text { Ayunan kedua } \\
\text { tangan ke sisi } \\
\text { kanan dan kiri } \\
\text { penari putra } \\
\text { dan putri } \\
1 \text { - } 8 \\
\text { Ayunan kedua } \\
\text { tangan ke sisi } \\
\text { kanan dan kiri } \\
\text { penari putra } \\
\text { dan putri } \\
1 \text { - } 8 \\
\text { Penari putra } \\
\text { mengitari } \\
\text { penari putri } \\
\text { dengan gerak } \\
\text { ayunan kedua } \\
\text { tangan } \\
1 \text { - } 8 \\
\text { Penari putri } \\
\text { mengitari } \\
\text { penari putra } \\
\text { dengan gerak } \\
\text { ayunan kedua } \\
\text { tangan }\end{array}$ & $\begin{array}{l}\text { Putri: Tangan kanan } \\
\text { ditekuk dengan sikap } \\
\text { telapak tangan } \\
\text { ngrayung berada di } \\
\text { depan dada dan } \\
\text { tangan kiri ditekuk } \\
\text { dengan sikap telapak } \\
\text { tangan ngrayung } \\
\text { berada di depang } \\
\text { pinggang. Kedua } \\
\text { tangan yang ditekuk } \\
\text { diayunkan ke kanan } \\
\text { dan kiri secara } \\
\text { bergantian, posisi } \\
\text { kaki lurus sejajar } \\
\text { membuka satu kepal } \\
\text { tangan dangan } \\
\text { gerakan jalan } \\
\text { ditempat. } \\
\text { Putra: sama dengan } \\
\text { gerak penari putri } \\
\text { hanya saja sikap } \\
\text { tangan dan kaki } \\
\text { berbeda. Sikap } \\
\text { tangan penari putra } \\
\text { kambeng, kaki } \\
\text { dibuka lebar dan } \\
\text { menghentak. }\end{array}$ & $\begin{array}{l}\text { Ragam gerak } \\
\text { lumaksono } \\
\text { ngracik } \\
\text { dilakukan } \\
\text { ketika iringan } \\
\text { tari masuk } \\
\text { pada musik } \\
\text { vokal dengan } \\
\text { suasana } \\
\text { sayup-sayup, } \\
\text { tempo gerak } \\
\text { sedang dan } \\
\text { ritmenya } \\
\text { ajeg. }\end{array}$ & 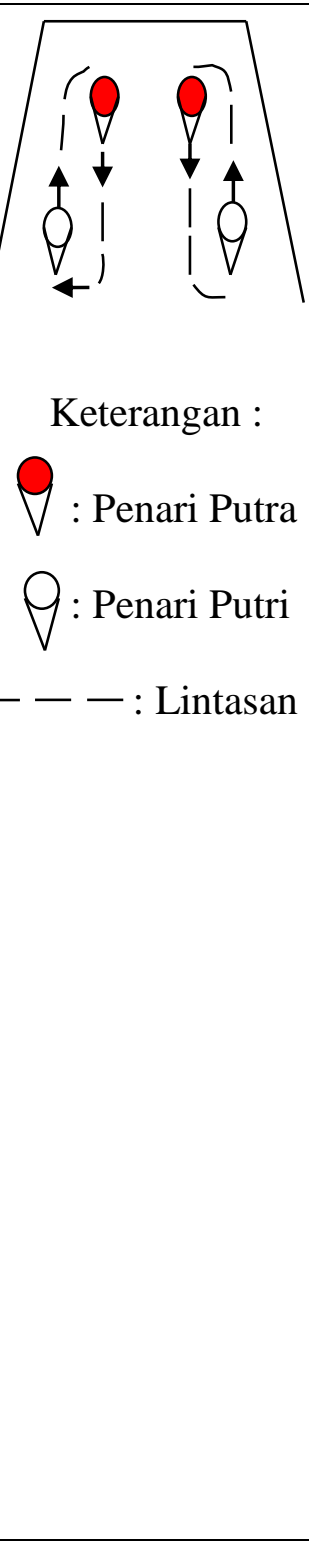 \\
\hline
\end{tabular}




\begin{tabular}{|c|c|c|c|c|c|}
\hline & & $\begin{array}{l}1 \text { - } 8 \\
\text { Ayunan kedua } \\
\text { tangan ke sisi } \\
\text { kanan kiri } \\
\text { penari putra } \\
\text { dan putri } \\
1 \text { - } 8 \\
\text { Ayunan kedua } \\
\text { tangan ke sisi } \\
\text { kanan kiri } \\
\text { penari putra } \\
\text { dan putri } \\
\text { sejajar }\end{array}$ & & & \\
\hline 2. & Penghubung & $\begin{array}{l}1 \text { x } 8 \text { hitungan } \\
\text { terdiri dari: } \\
1 \text { - } 4 \\
\text { Penari putri } \\
\text { melakukan } \\
\text { gerakan } \\
\text { lontang kedua } \\
\text { tangan ke sisi } \\
\text { kanan } \\
\text { penari putra } \\
\text { merentangkan } \\
\text { kedua tangan } \\
5 \text { - } 6 \\
\text { Penari putri } \\
\text { melakukan } \\
\text { gerakan } \\
\text { lontang kedua } \\
\text { tangan ke sisi } \\
\text { kiri } \\
\text { penari putra } \\
\text { menyilangkan } \\
\text { kedua tangan } \\
7 \\
\text { Penari putri } \\
\text { lontang kedua } \\
\text { tangan ke sisi } \\
\text { kanan dengan } \\
\text { kaki kanan } \\
\text { mancat }\end{array}$ & 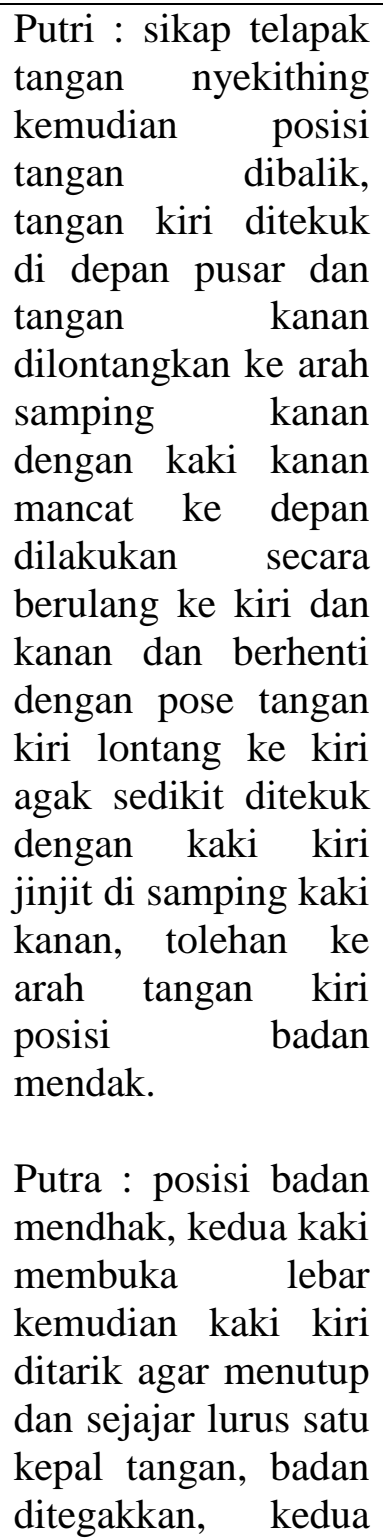 & $\begin{array}{l}\text { Ragam gerak } \\
\text { penghubung } \\
\text { dilakukan } \\
\text { ketika iringan } \\
\text { tari masuk } \\
\text { pada musik } \\
\text { vokal dengan } \\
\text { suasana } \\
\text { sayup-sayup, } \\
\text { tempo gerak } \\
\text { sedang dan } \\
\text { ritmenya } \\
\text { tidak ajeg. }\end{array}$ & 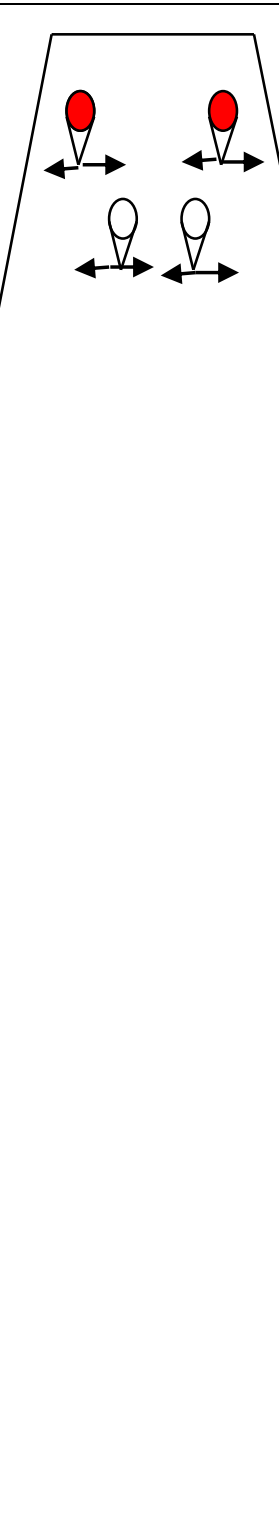 \\
\hline
\end{tabular}




\begin{tabular}{|c|c|c|c|c|c|}
\hline & & $\begin{array}{l}\text { kedepan, } \\
\text { penari putra } \\
\text { menyilangkan } \\
\text { kedua tangan } \\
\text { di depan dada } \\
8 \\
\text { Penari putri } \\
\text { lontang tangan } \\
\text { ke kiri kaki } \\
\text { kiri jinjit, } \\
\text { penari putra } \\
\text { mendhak } \\
\text { kedua tangan } \\
\text { menggeser } \\
\text { caping diatas } \\
\text { kepala }\end{array}$ & 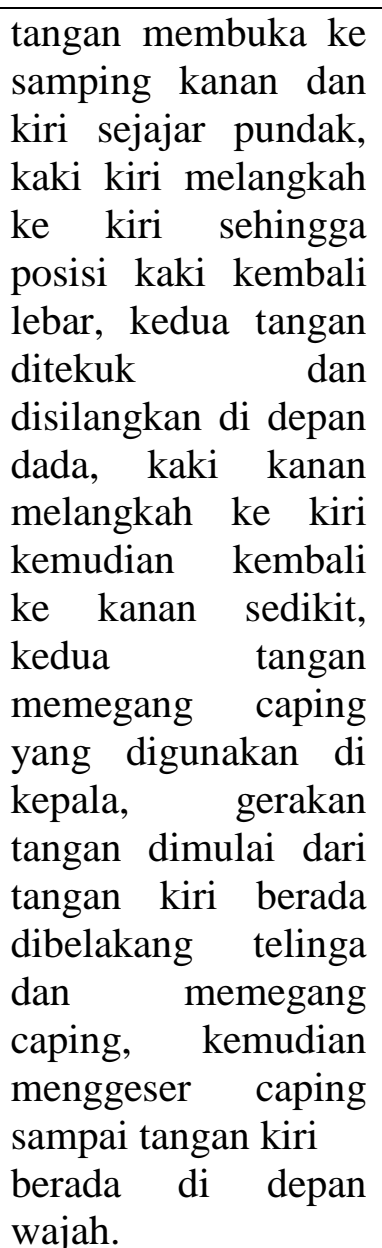 & & \\
\hline 3. & Srisig & $\begin{array}{l}2 \text { x } 8 \text { hitungan } \\
\text { terdiri dari: } \\
1 \text { - } 8 \\
\text { Penari putri } \\
\text { berputar } \\
\text { mengangkat } \\
\text { caping dan } \\
\text { berjalan ke } \\
\text { arah kiri, } \\
\text { penari putra } \\
\text { mengangkat } \\
\text { caping dan } \\
\text { menggetarkan } \\
\text { didepan dada } \\
\text { dengan } \\
\text { berjalan } \\
\text { mundur ke } \\
\text { arah kiri }\end{array}$ & 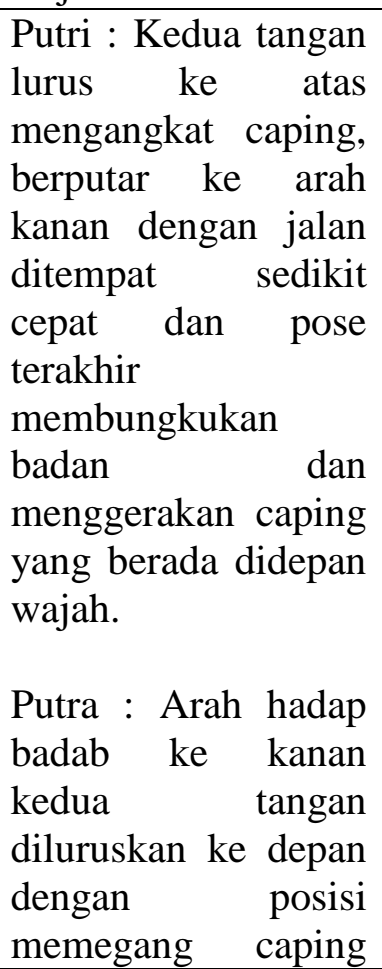 & $\begin{array}{l}\text { Ragam gerak } \\
\text { srisig } \\
\text { dilakukan } \\
\text { ketika iringan } \\
\text { tari masuk } \\
\text { pada bagian } \\
\text { musik } \\
\text { berirama } \\
\text { dengan } \\
\text { suasana } \\
\text { riang, tempo } \\
\text { gerak yang } \\
\text { dilakukan } \\
\text { cepat dan } \\
\text { ritme } \\
\text { geraknya } \\
\text { ajeg. }\end{array}$ & 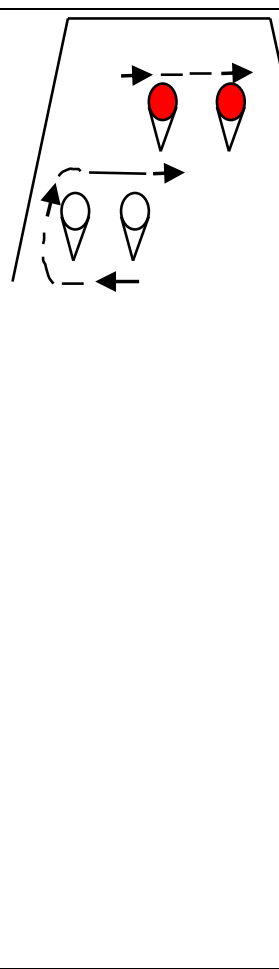 \\
\hline
\end{tabular}




\begin{tabular}{|c|c|c|c|c|c|}
\hline & & $\begin{array}{l}\text { 1- } 8 \\
\text { Badan penari } \\
\text { putra dan putri } \\
\text { hadap depan, } \\
\text { membungkuk } \\
\text { dan kedua } \\
\text { tangan } \\
\text { menggetarkan } \\
\text { caping di } \\
\text { depan wajah }\end{array}$ & $\begin{array}{l}\text { berjalan mundur } \\
\text { sambil } \\
\text { menggetarkan kedua } \\
\text { pundak dan } \\
\text { menggerakan caping } \\
\text { dengan posisi badan } \\
\text { membungkuk dan } \\
\text { caping menutupi } \\
\text { wajah. }\end{array}$ & & \\
\hline 4. & Nandur & $\begin{array}{l}4 \text { x } 8 \text { hitungan } \\
\text { terdiri dari: } \\
1 \text { - } 2 \\
\text { penari putra } \\
\text { dan putri } \\
\text { merentangkan } \\
\text { kaki kanan } \\
\text { mancat ke } \\
\text { samping } \\
\text { kanan, tangan } \\
\text { kanan lurus ke } \\
\text { bawah berada } \\
\text { di depan kaki } \\
\text { kiri, tangan } \\
\text { kiri memegang } \\
\text { caping, } \\
\text { kemudian kaki } \\
\text { kiri geser ke } \\
\text { arah kanan } \\
\text { diikuti tangan } \\
\text { kanan lurus ke } \\
\text { bawah di } \\
\text { depan kaki } \\
\text { kanan } \\
3 \text { - } 4 \\
\text { Penari putra } \\
\text { dan putri } \\
\text { merentangkan } \\
\text { kaki kanan } \\
\text { mancat ke } \\
\text { samping } \\
\text { kanan, tangan } \\
\text { kanan lurus ke } \\
\text { bawah berada }\end{array}$ & 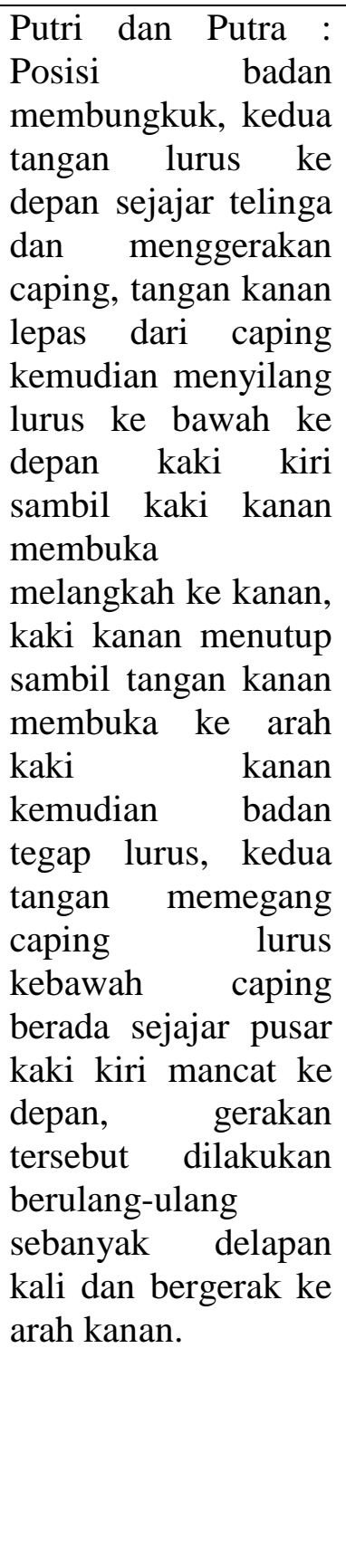 & $\begin{array}{l}\text { Ragam gerak } \\
\text { nandur } \\
\text { dilakukan } \\
\text { ketika iringan } \\
\text { masuk pada } \\
\text { bagian musik } \\
\text { berirama } \\
\text { dengan } \\
\text { suasana } \\
\text { riang, tempo } \\
\text { gerak yang } \\
\text { dilakukan } \\
\text { cepat dan } \\
\text { ritme } \\
\text { geraknya } \\
\text { ajeg. }\end{array}$ & $\int_{4--4}^{8} \theta$ \\
\hline
\end{tabular}




\begin{tabular}{|c|c|c|c|c|c|}
\hline & & $\begin{array}{l}\text { di depan kaki } \\
\text { kiri, tangan } \\
\text { kiri memegang } \\
\text { caping, } \\
\text { kemudian kaki } \\
\text { kiri mancat ke } \\
\text { depan, kedua } \\
\text { tangan } \\
\text { menekan } \\
\text { caping ke } \\
\text { bawah posisi } \\
\text { badan lurus } \\
\text { Dilakukan } \\
\text { berulang-ulang } \\
\text { sebanyak } 4 \text { x } 8 \\
\text { hitungan } \\
\text { dengan } \\
\text { gerakan sama }\end{array}$ & & & \\
\hline 5. & $\begin{array}{l}\text { Ngusir } \\
\text { Manuk }\end{array}$ & $\begin{array}{l}6 \text { x } 8 \text { hitungan } \\
\text { terdiri dari: } \\
1 \text { - } 4 \\
\text { Kedua tangan } \\
\text { penari putri } \\
\text { ngrayung dan } \\
\text { berputar, kaki } \\
\text { kiri penari } \\
\text { putra } \\
\text { membuka ke } \\
\text { samping kiri } \\
\text { kedua tangan } \\
\text { memegang } \\
\text { caping } \\
\text { digerakan ke } \\
\text { arah kiri dan } \\
\text { kanan } \\
5 \text { - 6 } \\
\text { Kedua tangan } \\
\text { penari putri } \\
\text { tepuk-tepuk } \\
\text { didepan dada } \\
\text { dari arah kanan } \\
\text { ke kiri, kaki } \\
\text { kanan penari }\end{array}$ & $\begin{array}{lr}\text { Putri : Kedua tangan } \\
\text { mengangkat caping } \\
\text { untuk dikenakan } \\
\text { diatas } r \text { kepala } \\
\text { kemudian berputar } \\
\text { ke arah kanan dan } \\
\text { kedua telapak tangan } \\
\text { ditepukkan, } \\
\text { selanjutnya kedua } \\
\text { tangan ditekuk } \\
\text { dengan sikap tangan } \\
\text { ngrayung, badan } \\
\text { serong kiri dan kaki } \\
\text { kanan diangkat. } \\
\text { Kemudian berputar } \\
\text { kembali ke arah } \\
\text { kanan dengan posisi } \\
\text { tangan ditekuk lurus } \\
\text { kedepan dengan } \\
\text { sikap tangan } \\
\text { ngrayung. Tangan } \\
\text { ditepukkan } \\
\text { kemudian dikibaskan } \\
\text { ke arah kiri, kaki kiri } \\
\text { melangkah ke kiri } \\
\text { sedikit dan kaki } \\
\text { kanan diloncatkan, }\end{array}$ & $\begin{array}{l}\text { Ragam gerak } \\
\text { ngusir manuk } \\
\text { dilakukan } \\
\text { ketika iringan } \\
\text { masuk pada } \\
\text { bagian musik } \\
\text { berirama } \\
\text { dengan } \\
\text { suasana } \\
\text { riang, tempo } \\
\text { gerak yang } \\
\text { dilakukan } \\
\text { cepat dan } \\
\text { ritme geraknya } \\
\text { ajeg. }\end{array}$ & 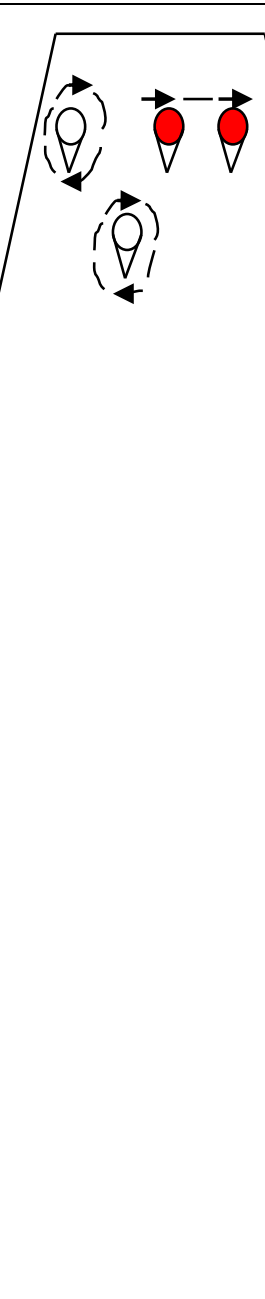 \\
\hline
\end{tabular}




\begin{tabular}{|c|c|c|c|c|}
\hline & & $\begin{array}{l}\text { putra geser ke } \\
\text { kanan kedua } \\
\text { tangan } \\
\text { mengangkat } \\
\text { caping lurus di } \\
\text { atas kepala } \\
7 \text { - } 8 \\
\text { Kedua tangan } \\
\text { penari putri } \\
\text { mengibaskan } \\
\text { ayunan tangan } \\
\text { ke samping } \\
\text { kiri dengan } \\
\text { kaki kanan } \\
\text { sedikit } \\
\text { diangkat dan } \\
\text { loncat, kedua } \\
\text { tangan penari } \\
\text { putra } \\
\text { menggetarkan } \\
\text { caping di } \\
\text { depan dada } \\
\text { dan kaki kiri } \\
\text { diangkat } \\
\text { sedikit } \\
\text { kemudian } \\
\text { loncat } \\
\text { Dilakukan } \\
\text { secara } \\
\text { berulang-ulang } \\
\text { dengan rincian } \\
\text { hitungan dan } \\
\text { gerak yang } \\
\text { sama, } \\
\text { sebanyak } 6 \text { x } 8 \\
\text { hitungan }\end{array}$ & 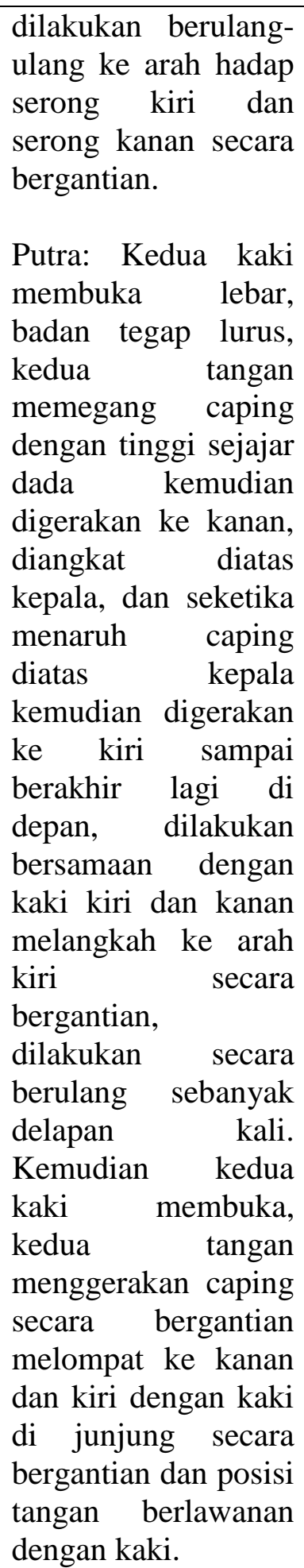 & \\
\hline 6. & Ngasoh & $\begin{array}{l}2 \times 8 \text { hitungan } \\
\text { terdiri dari: } \\
1-8 \\
\text { Kedua tangan }\end{array}$ & $\begin{array}{lr}\text { Kedua } & \text { tangan } \\
\text { mengangkat caping } \\
\text { lurus diatas kepala, } \\
\text { kaki jinjit dan } \\
\text { berputar membuat }\end{array}$ & $\begin{array}{l}\text { Ragam gerak } \\
\text { ngasoh } \\
\text { dilakukan } \\
\text { ketika iringan } \\
\text { masuk pada }\end{array}$ \\
\hline
\end{tabular}




\begin{tabular}{|c|c|c|c|c|c|}
\hline & & $\begin{array}{l}\text { penari putra } \\
\text { dan putri } \\
\text { mengangkat } \\
\text { caping dan } \\
\text { berputar } \\
1 \text { - } 4 \\
\text { Penari putri } \\
\text { jongkok hadap } \\
\text { kiri dengan } \\
\text { kedua tangan } \\
\text { meletakkan } \\
\text { caping di } \\
\text { depan kaki, } \\
\text { penari putra } \\
\text { mengangkat } \\
\text { caping dan } \\
\text { berputar ke kiri } \\
5 \text { - } 8 \\
\text { Penari putri } \\
\text { jongkok hadap } \\
\text { kanan dengan } \\
\text { kedua tangan } \\
\text { meletakkan } \\
\text { caping di } \\
\text { depan kaki, } \\
\text { penari putra } \\
\text { mengangkat } \\
\text { caping dan } \\
\text { berputar ke } \\
\text { kanan }\end{array}$ & $\begin{array}{l}\text { lintasan antar penari } \\
\text { kemudian penari } \\
\text { putri jengkeng } \\
\text { menghadap ke kiri } \\
\text { dengan posisi caping } \\
\text { di depan dan } \\
\text { menyamping badan, } \\
\text { berada di depan kaki } \\
\text { kanan, dibolak-balik } \\
\text { ke kanan dan ke kiri } \\
\text { secara bergantian } \\
\text { sebanyak dua kali. } \\
\text { Selanjutnya berdiri } \\
\text { dan berputar kanan } \\
\text { dengan posisi badan } \\
\text { membungkuk tangan } \\
\text { memegang caping } \\
\text { yang berada didepan } \\
\text { pinggul kiri. }\end{array}$ & $\begin{array}{l}\text { bagian musik } \\
\text { konflik } \\
\text { dengan } \\
\text { suasana } \\
\text { tegang, } \\
\text { tempo gerak } \\
\text { yang } \\
\text { dilakukan } \\
\text { lambat dan } \\
\text { ritme } \\
\text { geraknya } \\
\text { tidak ajeg. }\end{array}$ & \\
\hline 7. & Mupuk Siram & $\begin{array}{l}4 \text { x } 8 \text { hitungan } \\
\text { terdiri dari: } \\
1 \text { - } 4 \\
\text { Penari putri } \\
\text { membolak- } \\
\text { balikan kedua } \\
\text { telapak tangan } \\
\text { di depan dada } \\
\text { dengan posisi } \\
\text { badan } \\
\text { membungkuk } \\
\text { dan kedua kaki } \\
\text { membuka }\end{array}$ & $\begin{array}{l}\text { Putri : Posisi badan } \\
\text { membungkuk, kedua } \\
\text { tangan meletakan } \\
\text { caping di atas } \\
\text { kepala, } \\
\text { membuka lebar, } \\
\text { kemudian bergerak } \\
\text { ke arah samping } \\
\text { kanan, dengan posisi } \\
\text { tangan didepan dada } \\
\text { di bolak-balikan } \\
\text { seperti menghentak } \\
\text { dengan sikap tangan } \\
\text { ngrayung. Kemudian }\end{array}$ & $\begin{array}{l}\text { Ragam gerak } \\
\text { mupuk siram } \\
\text { dilakukan } \\
\text { ketika iringan } \\
\text { masuk pada } \\
\text { bagian musik } \\
\text { konflik } \\
\text { dengan } \\
\text { suasana } \\
\text { tegang, } \\
\text { tempo gerak } \\
\text { yang } \\
\text { dilakukan } \\
\text { cepat dan }\end{array}$ & $\begin{array}{l}10> \\
10> \\
\downarrow \\
1 \theta \downarrow \theta\end{array}$ \\
\hline
\end{tabular}




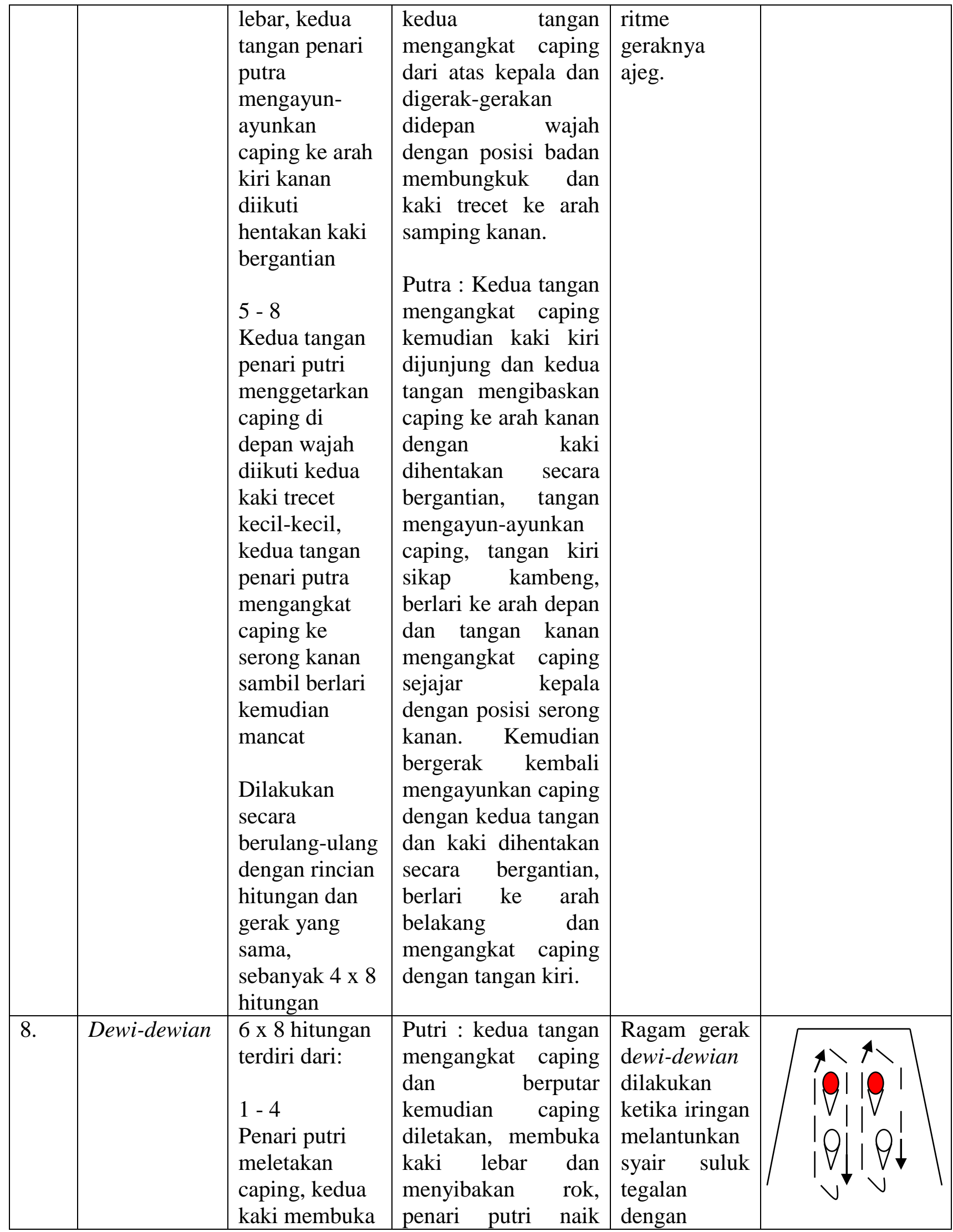




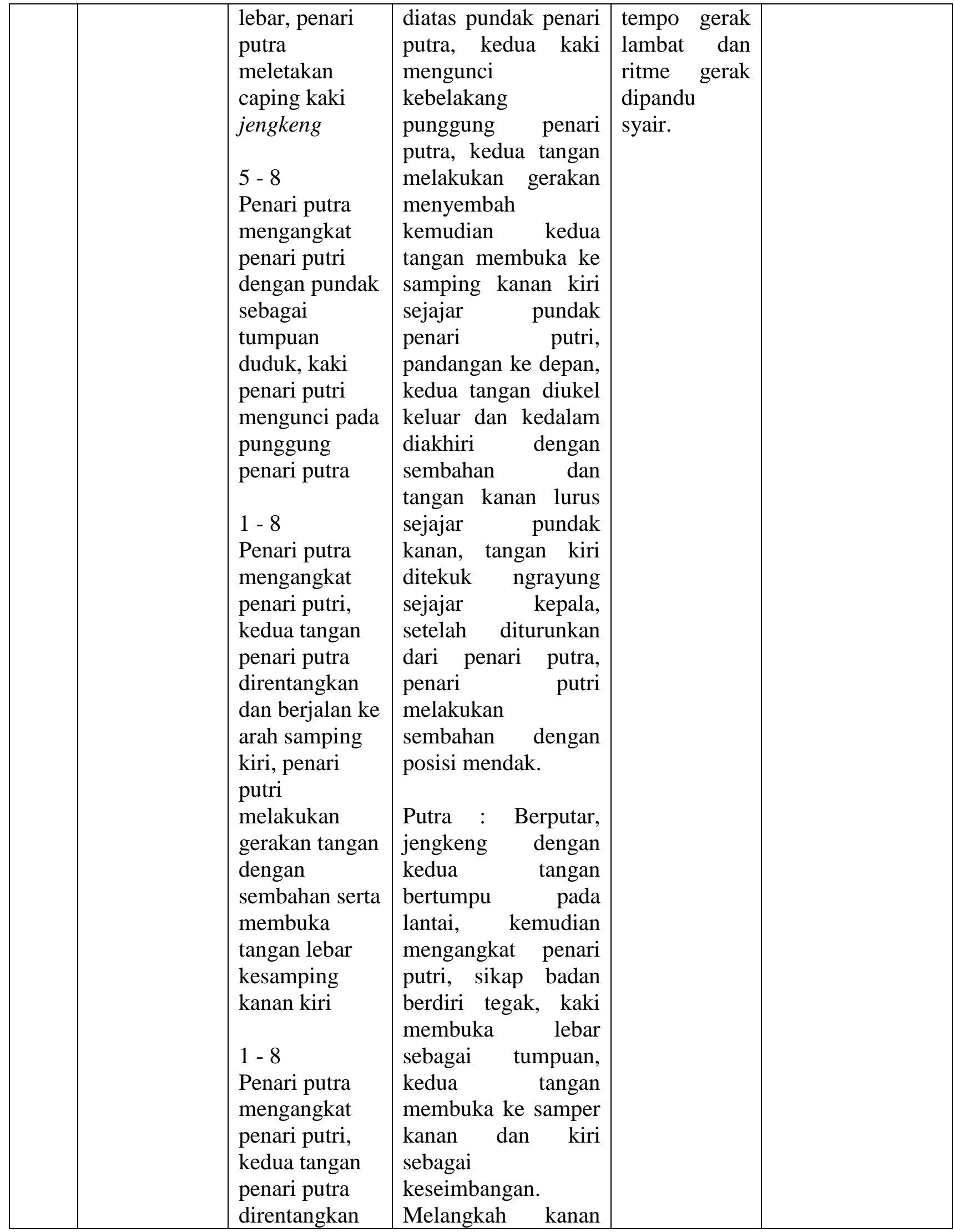




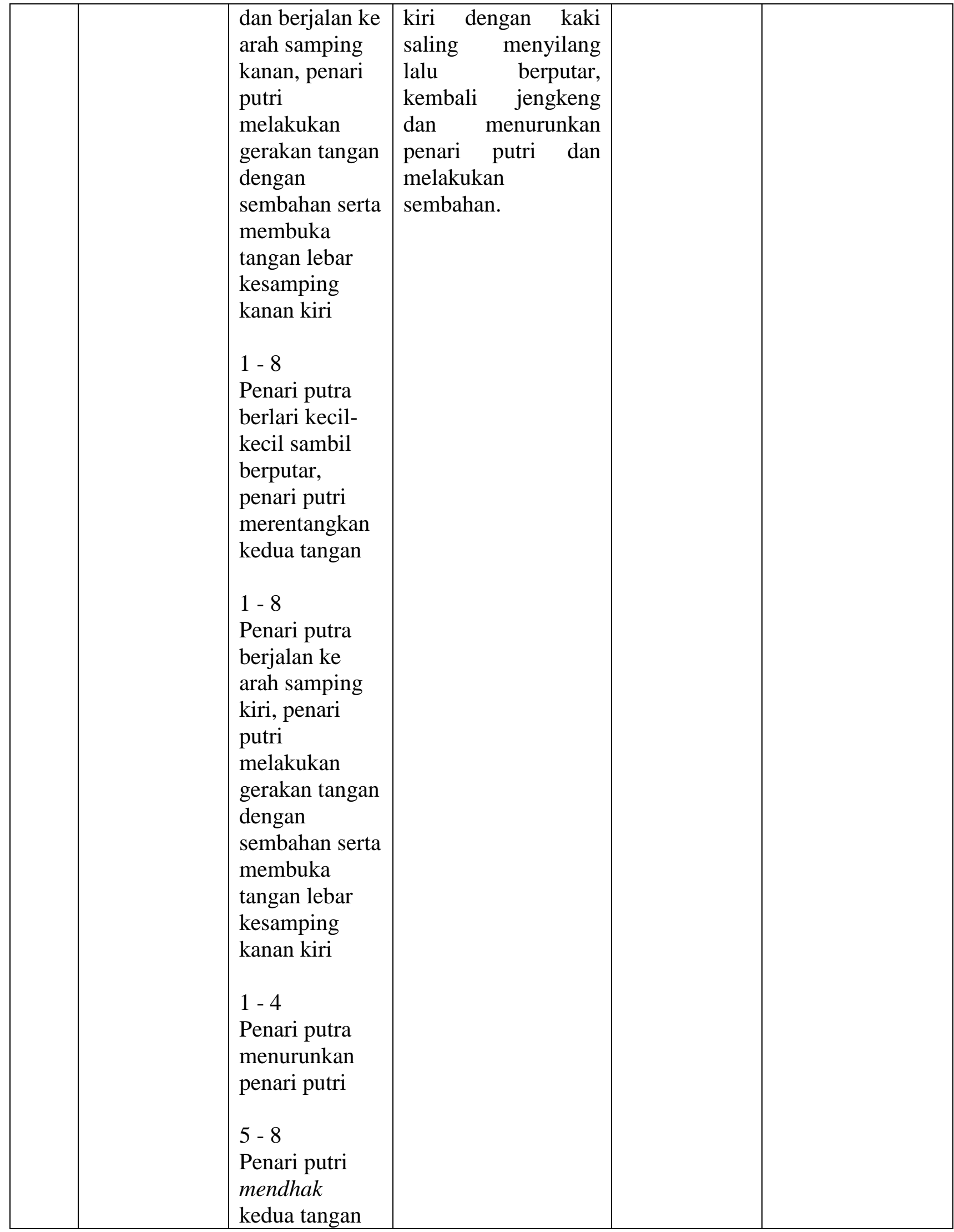




\begin{tabular}{|c|c|c|c|c|c|}
\hline & & $\begin{array}{l}\text { disatukan } \\
\text { melakukan } \\
\text { sembahan, } \\
\text { penari putra } \\
\text { jengkeng } \\
\text { kedua tangan } \\
\text { melakukan } \\
\text { sembahan }\end{array}$ & & & \\
\hline 9. & Ngani-ani & $\begin{array}{l}6 \text { x } 8 \text { hitungan } \\
\text { terdiri dari: } \\
1 \text { - } 2 \\
\text { Tangan kiri } \\
\text { penari putri } \\
\text { memegang } \\
\text { caping terbalik } \\
\text { di sisi pinggul } \\
\text { kiri, tangan } \\
\text { kanan } \\
\text { ngrayung } \\
\text { bergerak } \\
\text { dibawah } \\
\text { caping dengan } \\
\text { kaki kiri } \\
\text { didepan, kedua } \\
\text { kaki penari } \\
\text { putra } \\
\text { membuka } \\
\text { lebar dan } \\
\text { berjalan ke } \\
\text { arah samping } \\
\text { kanan dengan } \\
\text { kedua tangan } \\
\text { direntangkan } \\
3 \text { - } 4 \\
\text { Tangan kanan } \\
\text { ngrayung } \\
\text { bergerak diatas } \\
\text { caping dengan } \\
\text { posisi kaki } \\
\text { kanan di } \\
\text { depan, kedua } \\
\text { kaki penari } \\
\text { putra } \\
\text { membuka }\end{array}$ & 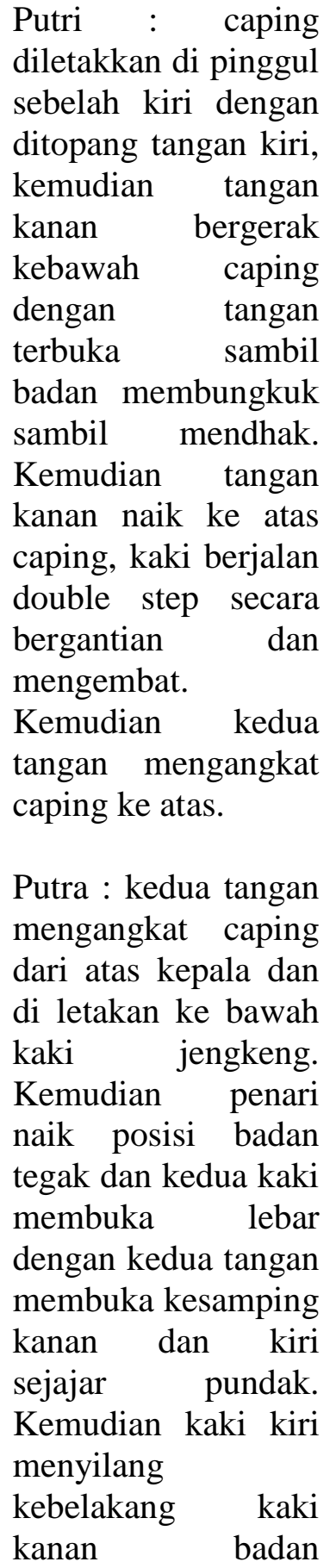 & $\begin{array}{l}\text { Ragam gerak } \\
\text { ngani-ani } \\
\text { dilakukan } \\
\text { ketika iringan } \\
\text { masuk pada } \\
\text { bagian } \\
\text { gendhing } \\
\text { lancaran } \\
\text { lesung } \\
\text { jumengglung } \\
\text { slendro sanga } \\
\text { dengan } \\
\text { suasana } \\
\text { sangat riang, } \\
\text { tempo gerak } \\
\text { sedang dan } \\
\text { ritme } \\
\text { geraknya } \\
\text { ajeg. }\end{array}$ & $-\frac{-}{-1}$ \\
\hline
\end{tabular}




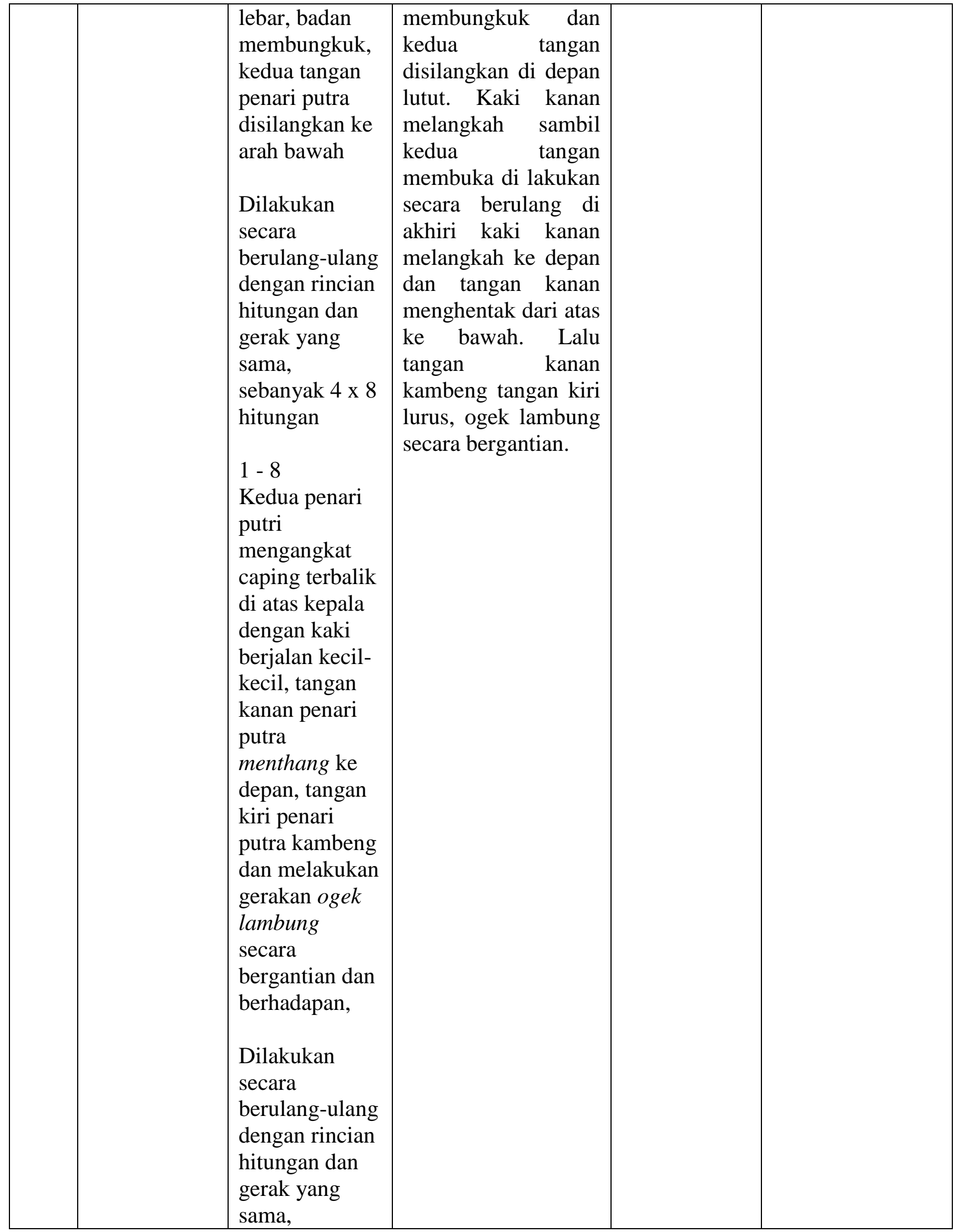




\begin{tabular}{|c|c|c|c|c|c|}
\hline & & $\begin{array}{l}\text { sebanyak } 2 \times 8 \\
\text { hitungan }\end{array}$ & & & \\
\hline 10. & Ndheplok & $\begin{array}{l}3 \text { x } 8 \text { hitungan } \\
\text { terdiri dari: } \\
1 \text { - } 8 \\
\text { Kedua tangan } \\
\text { penari putri } \\
\text { ditekan } \\
\text { kebawah kaki } \\
\text { kanan kiri } \\
\text { bergantian } \\
\text { mancat } \\
\text { kedepan, } \\
\text { kedua tangan } \\
\text { penari putra } \\
\text { ngepel dengan } \\
\text { kaki kanan dan } \\
\text { kiri onclang } \\
\text { secara } \\
\text { bergantian } \\
\text { Dilakukan } \\
\text { secara } \\
\text { berulang-ulang } \\
\text { dengan rincian } \\
\text { hitungan dan } \\
\text { gerak yang } \\
\text { sama, } \\
\text { sebanyak } 3 \text { x } 8 \\
\text { hitungan }\end{array}$ & $\begin{array}{lr}\begin{array}{l}\text { Putri : kedua tangan } \\
\text { di gerakan naik turun } \\
\text { kaki } \\
\text { bergantian. }\end{array} \\
\begin{array}{lr}\text { Putra } \\
\text { melakukan }\end{array} \\
\begin{array}{l}\text { junjungan } \\
\text { lompat }\end{array} \\
\begin{array}{lr}\text { bergantian } \\
\text { gerakan di }\end{array} \\
\begin{array}{l}\text { ngepel teambil } \\
\text { kambeng }\end{array} \\
\text { bergantian. }\end{array}$ & $\begin{array}{l}\text { Ragam gerak } \\
\text { ndheplok } \\
\text { dilakukan } \\
\text { ketika iringan } \\
\text { masuk pada } \\
\text { bagian } \\
\text { gendhing } \\
\text { lancaran } \\
\text { lesung } \\
\text { jumengglung } \\
\text { slendro sanga } \\
\text { dengan } \\
\text { suasana } \\
\text { sangat riang, } \\
\text { tempo gerak } \\
\text { cepat dan } \\
\text { ritme } \\
\text { geraknya } \\
\text { ajeg. }\end{array}$ & 4 \\
\hline 11. & $\begin{array}{l}\text { Lembehan } \\
\text { Leyeh }\end{array}$ & $\begin{array}{l}2 \text { x } 8 \text { hitungan } \\
\text { terdiri dari: } \\
1 \text { - } 4 \\
\text { Kedua tangan } \\
\text { penari putri } \\
\text { lontang kanan } \\
\text { kaki kiri } \\
\text { mancat depan } \\
\text { dan kedua } \\
\text { tangan } \\
\text { dihentakaan, } \\
\text { kedua tangan } \\
\text { penari putra } \\
\text { kambeng, ogek }\end{array}$ & 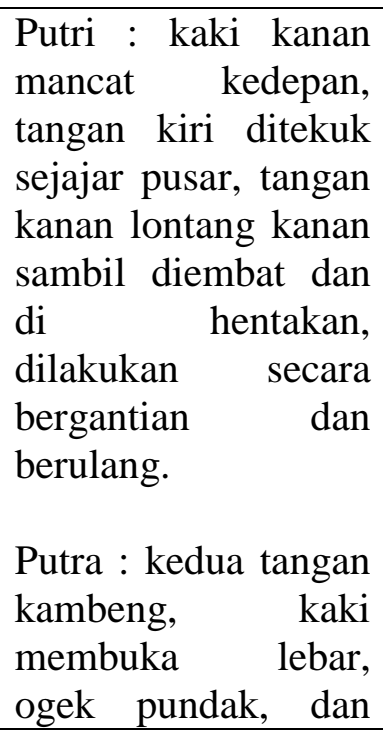 & $\begin{array}{l}\text { Ragam gerak } \\
\text { lembehan } \\
\text { leyeh } \\
\text { dilakukan } \\
\text { ketika iringan } \\
\text { masuk pada } \\
\text { bagian } \\
\text { gendhing } \\
\text { lancaran } \\
\text { lesung } \\
\text { jumengglung } \\
\text { slendro sanga } \\
\text { dengan } \\
\text { suasana } \\
\text { sangat riang, } \\
\end{array}$ & 9 \\
\hline
\end{tabular}




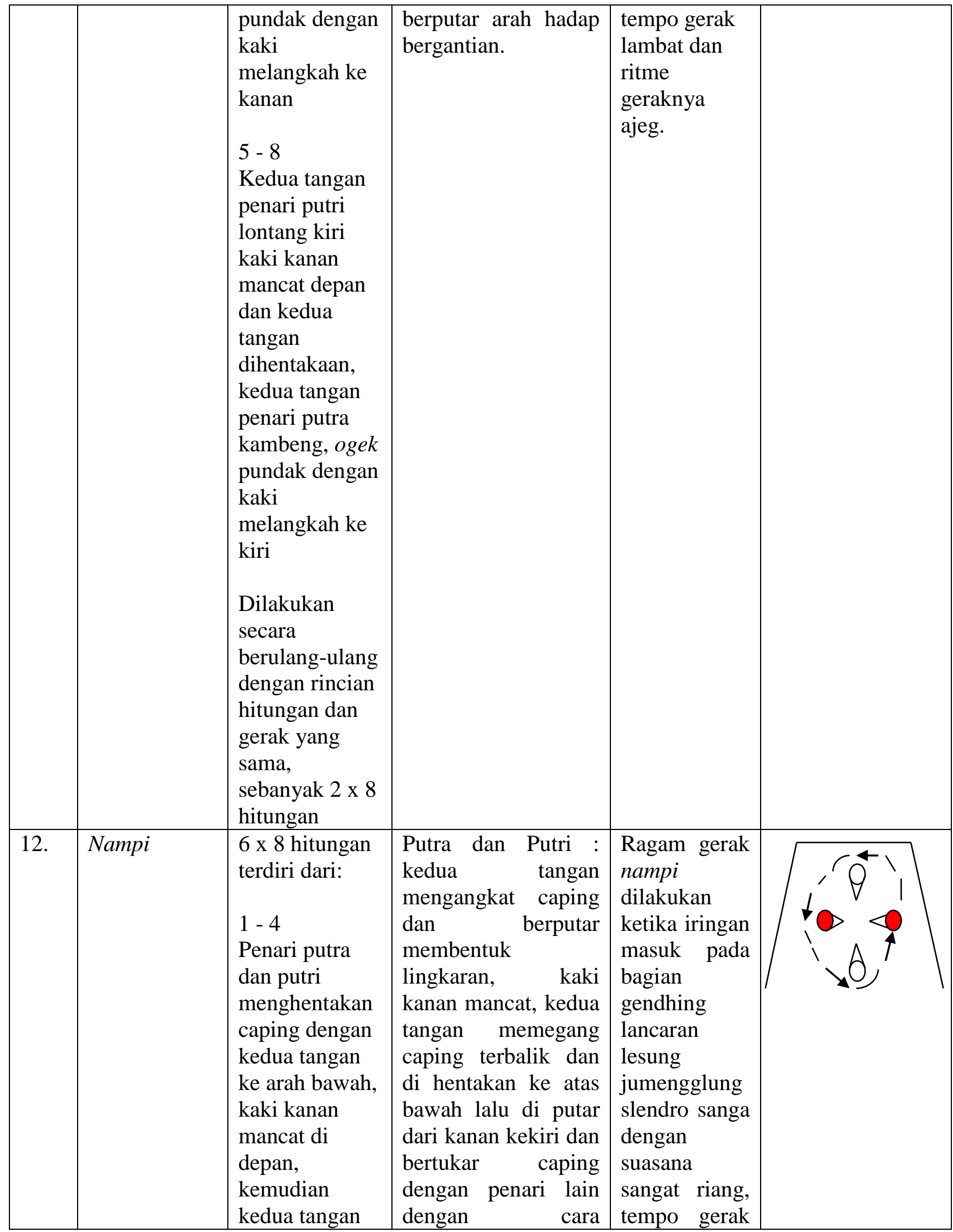




\begin{tabular}{|c|c|c|c|c|c|}
\hline & & $\begin{array}{l}\text { memutar } \\
\text { caping dari } \\
\text { arah kiri ke } \\
\text { kanan lalu di } \\
\text { lempar ke } \\
\text { penari di } \\
\text { sampingnya } \\
5 \text { - } 8 \\
\text { Kedua tangan } \\
\text { penari putra } \\
\text { dan putri } \\
\text { menghentak- } \\
\text { hentakan } \\
\text { caping di } \\
\text { samping kanan } \\
\text { sejajar dengan } \\
\text { kepala } \\
\text { Dilakukan } \\
\text { secara } \\
\text { berulang-ulang } \\
\text { dengan rincian } \\
\text { hitungan dan } \\
\text { gerak yang } \\
\text { sama, } \\
\text { sebanyak } 2 \text { x } 8 \\
\text { hitungan }\end{array}$ & $\begin{array}{l}\text { dilempar, kaki kanan } \\
\text { menghentak, } \\
\text { hentakan sesui } \\
\text { hentakan tangan, } \\
\text { gerakan di lakukan } \\
\text { secara berulang dan } \\
\text { bergantian. } \\
\text { Kemudian caping di } \\
\text { angkat sejajar } \\
\text { kepala, kaki kanan di } \\
\text { hentak hentakan } \\
\text { sambil tangan } \\
\text { mengayunkan caping } \\
\text { ke atas bawah. }\end{array}$ & $\begin{array}{l}\text { sedang dan } \\
\text { ritme } \\
\text { geraknya } \\
\text { ajeg. }\end{array}$ & \\
\hline 13. & Seak & $\begin{array}{l}8 \times 8 \text { hitungan } \\
\text { terdiri dari: } \\
1 \text { - } 8 \\
\text { Tangan kiri } \\
\text { penari putri } \\
\text { memegang } \\
\text { caping, tangan } \\
\text { kanan } \\
\text { mengayun ke } \\
\text { depan } \\
\text { belakang } \\
\text { bergantian, } \\
\text { kaki jalan } \\
\text { ditempat, } \\
\text { kedua tangan } \\
\text { penari putra } \\
\text { merentang di }\end{array}$ & 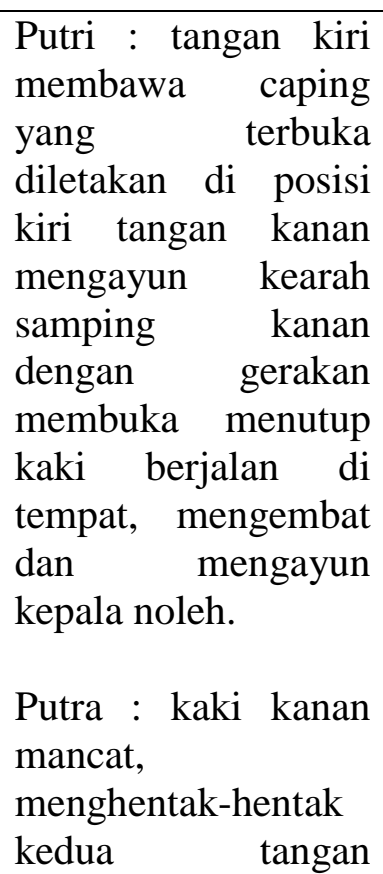 & $\begin{array}{l}\text { Ragam gerak } \\
\text { seak } \\
\text { dilakukan } \\
\text { ketika iringan } \\
\text { masuk pada } \\
\text { bagian musik } \\
\text { kenthongan } \\
\text { sampai musik } \\
\text { ending } \\
\text { dengan } \\
\text { suasana } \\
\text { sangat riang, } \\
\text { tempo gerak } \\
\text { lambat } \\
\text { mengayun } \\
\text { dan ritme } \\
\text { geraknya } \\
\text { ajeg. }\end{array}$ & $\left.\left.\right|_{V} ^{V 4} \rightarrow\right|_{V} ^{V} \rightarrow$ \\
\hline
\end{tabular}




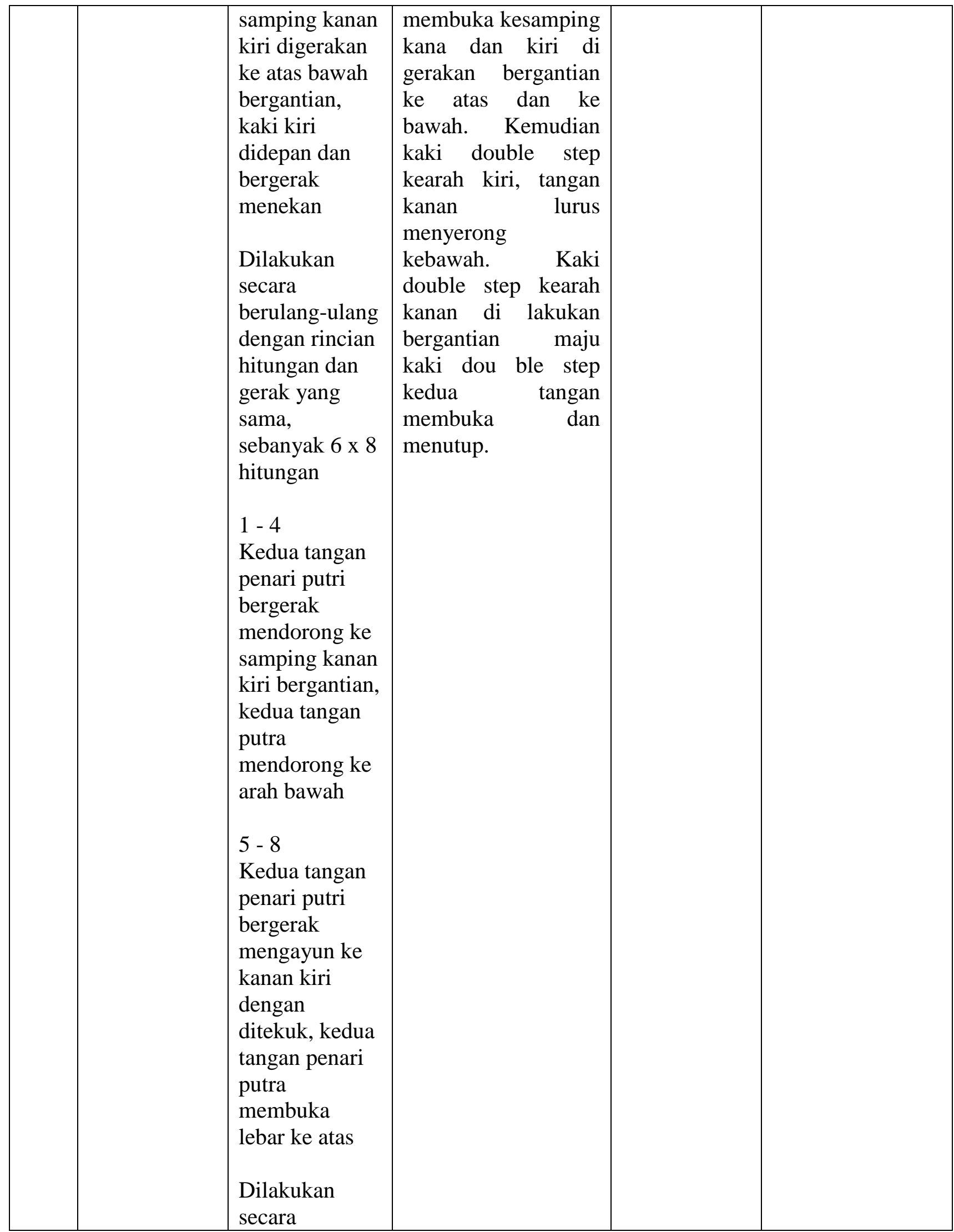




\begin{tabular}{|l|l|l|l|}
\hline & $\begin{array}{l}\text { berulang-ulang } \\
\text { dengan rincian } \\
\text { hitungan dan } \\
\text { gerak yang } \\
\text { sama, } \\
\text { sebanyak } 2 \times 8 \\
\text { hitungan }\end{array}$ & & \\
\hline
\end{tabular}

(Wawancara: Sri Damayanti, 6 Juni 2017)

\subsection{Unsur Gerak Tari Lenggang Pari}

Unsur gerak sebagai elemen dasar tari adalah bagian terkecil dari gerak tari. Unsur gerak dilakukan oleh bagian-bagian tubuh sebagai media bahan baku yang meliputi kepala, tangan, badan dan kaki. Unsur gerak tari Lenggang Pari dapat diidentifikasi dalam unsur gerak kepala, tangan, sikap badan dan kaki.

Tabel 4.7 Unsur Gerak Kepala Tari Lenggang Pari

\begin{tabular}{|l|c|c|l|}
\hline No. & \multicolumn{1}{|c|}{ Sikap } & Gerak & \multicolumn{1}{c|}{ Deskripsi } \\
\hline 1. & Tolehan kanan & - & $\begin{array}{l}\text { Menggerakan kepala dengan menolehkan } \\
\text { kepala ke arah samping kanan. }\end{array}$ \\
\hline 2. & Tolehan kiri & - & $\begin{array}{l}\text { Menggerakan kepala dengan menolehkan } \\
\text { kepala ke arah samping kiri. }\end{array}$ \\
\hline 3. & Tolehan depan & - & Wajah melihat ke depan \\
\hline 4. & - & Pacak gulu & $\begin{array}{l}\text { Menggerakan kepala ke kiri atau kanan. } \\
\text { Menggerakannya tidak dengan } \\
\text { memalingkan kepala begitu saja, tetapi } \\
\text { dengan diputar seperti membentuk huruf } \\
\text { "S" }\end{array}$ \\
\hline 5. & - & Lenggut & $\begin{array}{l}\text { Menggerakan kepala ke depan dengan } \\
\text { memajukan dagu lalu ditekankan dan } \\
\text { leher menarik ke belakang. }\end{array}$ \\
\hline 6. & - & Gebes & $\begin{array}{l}\text { Menggerakan kepala ke kanan atau ke kiri } \\
\text { dengan keras }\end{array}$ \\
\hline
\end{tabular}

(Wawancara: Sri Damayanti, 6 Juni 2017)

Tabel 4.8 Unsur Gerak Tangan Tari Lenggang Pari

\begin{tabular}{|c|c|c|c|}
\hline No. & Sikap & Gerak & \multicolumn{2}{|c|}{ Deskripsi } \\
\hline 1. & Ngrayung & - & $\begin{array}{l}\text { Pergelangan tangan ditekuk berdiri } \\
\text { dengan jari telunjuk, jari tengah, jari }\end{array}$ \\
\hline
\end{tabular}




\begin{tabular}{|c|c|c|c|}
\hline & & & $\begin{array}{l}\text { manis dan kelingking berdiri jajar dan } \\
\text { rapat, ibu jari ditekuk ke depan telapak } \\
\text { tangan }\end{array}$ \\
\hline 2. & Nyekithing & - & $\begin{array}{l}\text { Ujung jari tengah berhimpitan dengan } \\
\text { ujung ibu jari (jempol) membentuk } \\
\text { lingkaran }\end{array}$ \\
\hline 3. & Mentang & - & $\begin{array}{l}\text { Meluruskan tangan ke samping dengan } \\
\text { lengan bawah maupun atas, biasanya } \\
\text { dalam posisi di samping badan, sikap } \\
\text { jarinya menurut ragam tarinya }\end{array}$ \\
\hline 4. & Sembahan & - & $\begin{array}{l}\text { Kedua telapak tangan saling bertemu } \\
\text { dengan jari-jari lurus ke atas }\end{array}$ \\
\hline 5. & Tawing & - & $\begin{array}{l}\text { Posisi tangan ngrayung yang terletak di } \\
\text { depan pundak. Tawing kanan dilakukan } \\
\text { tangan kanan yang diletakan di depan } \\
\text { pundak kiri. Tawing kiri tangan kiri di } \\
\text { depan pundak kanan }\end{array}$ \\
\hline 6. & Malangkerik & - & $\begin{array}{l}\text { Posisi tangan berkacak pinggang jari bisa } \\
\text { nyekithing atau memegang pangkal } \\
\text { sampur }\end{array}$ \\
\hline 7. & - & Ukel & $\begin{array}{l}\text { Gerakan tangan dengan memutar } \\
\text { pergelangan tangan berlawanan arah } \\
\text { jarum jam, dengan posisi ngithing }\end{array}$ \\
\hline 8. & Nggrodha & - & $\begin{array}{l}\text { Siku ditekuk siku-siku, pergelangan } \\
\text { tangan menghadap pada badan. }\end{array}$ \\
\hline 9. & Kambeng & - & $\begin{array}{l}\text { Tangan kiri dan kanan nggrodha segaris } \\
\text { bahu, jari tangan kiri dan kanan } \\
\text { menggenggam. Jari kelingking kanan } \\
\text { dikeluarkan sedikit. Telapak tangan } \\
\text { menghadap ke depan. Pandangan pada } \\
\text { siku kanan }\end{array}$ \\
\hline 10. & $\begin{array}{l}\text { Naga } \\
\text { Rangsang }\end{array}$ & - & Jari menggenggam ibu jari keluar \\
\hline 11. & - & Tepuk & $\begin{array}{l}\text { Kedua telapak tangan dipertemukan dan } \\
\text { dihentakan secara berulang-ulang }\end{array}$ \\
\hline 12. & - & Silang & $\begin{array}{l}\text { Tangan kiri berada di depan tangan kanan } \\
\text { atau sebaliknya }\end{array}$ \\
\hline 13. & Panggel & - & $\begin{array}{l}\text { Mengadu pangkal pergelangan tangan. } \\
\text { Telapak tangan kanan lurus ke atas, } \\
\text { telapak tangan kiri lurus ke bawah. }\end{array}$ \\
\hline 14. & - & Seak & \\
\hline 15. & $\begin{array}{l}\text { Baya } \\
\text { Mangap }\end{array}$ & - & $\begin{array}{l}\text { Jari rapat dan lurus. Ibu jari agak } \\
\text { membuka dan maju sedikit. }\end{array}$ \\
\hline
\end{tabular}

(Wawancara: Sri Damayanti, 6 Juni 2017) 
Tabel 4.9 Unsur Gerak Badan Tari Lenggang Pari

\begin{tabular}{|l|l|l|l|}
\hline No. & \multicolumn{1}{|c|}{ Sikap } & \multicolumn{1}{|c|}{ Gerak } & \multicolumn{1}{c|}{ Deskripsi } \\
\hline 1. & - & Oklak & $\begin{array}{l}\text { Menggerakan pundak ke depan dan ke } \\
\text { belakang. }\end{array}$ \\
\hline 2. & - & Entrag & $\begin{array}{l}\text { Menghentakkan badan ke bawah berkali- } \\
\text { kali, seolah-olah badan mengeper. }\end{array}$ \\
\hline 3. & Leyek & - & $\begin{array}{l}\text { Badan dicondongkan ke kiri atau ke kanan } \\
\text { dengan sikap tangan menthang lurus ke } \\
\text { samping. Lutut ditekuk ke depan. }\end{array}$ \\
\hline 4. & - & Hoyog & $\begin{array}{l}\text { Badan dicondongkan ke samping kanan } \\
\text { atau ke samping kiri. Kedua lutut ditekuk } \\
\text { sedikit. Badan bagian atas digerakkan ke } \\
\text { kiri atau ke kanan dengan lembut beberapa } \\
\text { kali (biasanya dua kali ke kiri, kembali ke } \\
\text { tengah atau ke kanan kembali ke tengah) }\end{array}$ \\
\hline 5. & - & Ngglebag & $\begin{array}{l}\text { Badan membalik ke kanan, ke kiri, atau ke } \\
\text { belakang. Waktu membalik, badan leyek } \\
\text { ke arah berlawanan. Kalau membalik ke } \\
\text { kanan, sikap badan condong ke kiri }\end{array}$ \\
\hline
\end{tabular}

(Wawancara: Sri Damayanti, 6 Juni 2017)

Tabel 4.10 Unsur Gerak Kaki Tari Lenggang Pari

\begin{tabular}{|c|c|l|l|}
\hline No. & Sikap & \multicolumn{1}{|c|}{ Gerak } & \multicolumn{1}{c|}{ Deskripsi } \\
\hline 1. & - & Debeg & Menghentakan ujung telapak kaki \\
\hline 2. & - & Gejuk & $\begin{array}{l}\text { Menjatuhkan ujung telapak kaki ke } \\
\text { belakang }\end{array}$ \\
\hline 3. & - & Napak & Melangkah \\
\hline 4. & - & Srisig & $\begin{array}{l}\text { Lari kecil dengan berjinjit. Untuk putri } \\
\text { langkah kecil-kecil sedangkan untuk putra } \\
\text { langkah kaki agak lebar. Biasanya srisig } \\
\text { putri kaki lurus sedangkan srisig putra } \\
\text { lutut agak ditekuk }\end{array}$ \\
\hline 5. & $\begin{array}{l}\text { Tanjak } \\
\text { Kanan }\end{array}$ & & $\begin{array}{l}\text { Jari kaki kanan menghadap ke samping } \\
\text { kanan. Kaki kiri serong ke kiri. Jempol } \\
\text { kaki kiri sejajar dengan tumit kaki kanan. } \\
\text { Posisi kaki dibuka lebar, berat badan ada } \\
\text { di kaki kiri }\end{array}$ \\
\hline 6. & Tanjak Kiri & & $\begin{array}{l}\text { Jari kaki kiri menghadap ke samping kiri. } \\
\text { Kaki kanan serong ke kanan. Jempol kaki } \\
\text { kanan sejajar dengan tumit kaki kiri. } \\
\text { Posisi kaki dibuka lebar, berat badan ada } \\
\text { di kaki kanan. }\end{array}$ \\
\hline 7. & - & & \\
\hline
\end{tabular}




\begin{tabular}{|c|c|c|c|}
\hline & & & $\begin{array}{l}\text { sebaliknya. Caranya tumit kaki kanan } \\
\text { digeser ke belakang hingga posisi serong } \\
\text { ke kanan. Bersamaan dengan tumit kaki } \\
\text { kiri digeser ke depan, sehingga posisi kaki } \\
\text { kiri menjadi horizontal. }\end{array}$ \\
\hline 8. & - & Trecet & $\begin{array}{l}\text { Bergerak ke kanan atau ke kiri dengan } \\
\text { posisi kaki tanjak, lutut tetap ditekuk, } \\
\text { telapak kaki jinjit bergerak ke kiri atau ke } \\
\text { kanan. Tangan biasanya ulap-ulap atau } \\
\text { menthang }\end{array}$ \\
\hline 9. & Mancat & - & $\begin{array}{l}\text { Kaki menyentuh dilantai dengan sedikit } \\
\text { jinjit dengan posisi kelima jari menghadap } \\
\text { ke atas }\end{array}$ \\
\hline 10. & Jengkeng & - & $\begin{array}{l}\text { Duduk seperti jongkok tetapi badan } \\
\text { bertumpu pada kaki kanan/kiri yang jinjit. } \\
\text { Sedang kaki yang lain tanjak kanan atau } \\
\text { kiri }\end{array}$ \\
\hline 11. & - & Gebreg & $\begin{array}{l}\text { Gerak meloncat tetapi dengan ketinggian } \\
\text { yang rendah }\end{array}$ \\
\hline 12. & Mendhak & - & $\begin{array}{l}\text { Pada waktu menari, kaki jarang sekali } \\
\text { dalam posisi berdiri lurus. Lutut kedua } \\
\text { kaki biasanya ditekuk sesuai dengan posisi } \\
\text { telapak kaki. Kalau telapak kaki lurus ke } \\
\text { depan, lutut ditekuk ke arah depan. Kalau } \\
\text { telapak kaki pada posisi ke samping, lutut } \\
\text { juga ditekuk ke arah samping }\end{array}$ \\
\hline 13. & - & Laku telu & $\begin{array}{l}\text { Kaki kanan melangkah ke depan } \\
\text { kemudian kaki kiri, lalu kaki kanan } \\
\text { mundur ke belakang dan kaki kiri gejuk }\end{array}$ \\
\hline 14. & Junjungan & - & $\begin{array}{l}\text { Kaki kanan atau kiri membentuk siku-siku } \\
\text { dan diangkat lurus sejajar pinggul, } \\
\text { kemudian kaki yang lain lurus }\end{array}$ \\
\hline 15. & - & Seleh & $\begin{array}{l}\text { Meletakan kaki kanan atau kiri ke posisi } \\
\text { tanjak kanan atau kiri }\end{array}$ \\
\hline
\end{tabular}

(Wawancara: Sri Damayanti, 6 Juni 2017)

\subsection{Nilai Keindahan Gerak Tari Lenggang Pari}

Nilai keindahan tari Lenggang Pari dapat dilihat dari aspek koreografi yang terdapat di dalamnya. Aspek koreografi terdiri dari aspek pokok tari dan aspek pendukung tari. Aspek pokok tari meliputi aspek tenaga, ruang dan waktu. Sedangkan aspek pendukung tari meliputi iringan, pelaku, tata rias wajah, tata rias 
wajah dan busana, tata lampu, tata suara, tempat pentas dan properti. Gerak dalam tari Lenggang Pari yang dilakukan berulang-ulang adalah ragam gerak lumaksono ngracik, penghubung, ngasoh dan srisig yang berfungsi sebagai gerak penghubung antar ragam yang satu ke gerak berikutnya. Berikut penjelasan ragam gerak tari Lenggang Pari:

\section{Lumaksono Ngracik}

Gerak lumaksono ngracik merupakan awal posisi penari saat di atas panggung. Posisi badan penari putri mendhak dengan kedua tangan ditekuk sikusiku dan telapak tangan ngrayung. Posisi badan penari putra mendhak dan membuka lebar, sikap tangan ditekuk siku-siku dengan jari menggenggam dan ibu jari keluar. Kaki diangkat sebatas mata kaki secara bergantian dengan gerakan jalan ditempat. Pandangan mata melihat lurus ke depan. Kepala dipatahkan ke kiri dan kanan secara bergantian seirama dengan gerakan kaki.

Nilai keindahan ragam gerak lumaksono ngracik dapat dilihat dari penggunaan tenaga meliputi intensitas, aksen dan kualitas yang digunakan oleh penari putri pada gerak lumaksono ngracik terasa mengalun sehingga menimbulkan kesan feminim dan lemah lembut. Sedangkan nilai keindahan ragam gerak lumaksono ngracik yang ditimbulkan oleh penari putra dengan penggunaan tenaga yang lebih besar karena volume gerak besar atau terbuka dan mempunyai watak kelaki-lakian memberikan kesan tari bersemangat dan kuat. Tidak ada tekanan atau aksen pada ragam gerak lumaksono ngracik yang dilakukan oleh penari putri dan putra, tenaganya merata sehingga menimbulkan kesan tari yang lemah lembut. 
Ekspresi wajah penari putri dibuat senyum manis untuk memberi kesan lembut sehingga mampu menghayati dan mengekspresikan secara totalitas jiwa dan mampu menggugah intuisi para penghayat. Posisis badan penari putri dan putra pada ragam gerak lumaksono ngracik membentuk garis tegak lurus yang memberikan kesan tenang dan seimbang dengan volume gerak yang kecil atau tertutup sehingga watak kewanitaan semakin nampak pada penari putri dan volume yang lebih besar atau terbuka mempunyai watak kelaki-lakian pada penari putra, sikap mendhak pada ragam lumaksono ngracik menunjukan level rendah yang memberi kesan tenang. Gerakan mengayunkan tangan pada ragam gerak lumaksono ngracik dengan tempo gerak lambat memberikan kesan lemah lembut disesuaikan dengan iringan tarinya yang mengalun, pengulangan gerak menimbulkan ritme ajeg yang mempunyai rasa keteraturan gerak dengan isian gerak sedikit dibandingkan dengan ketukan memberikan kesan lemah lembut. Perbedaan antara penari putri dan putra hanya terletak pada volume geraknya saja.

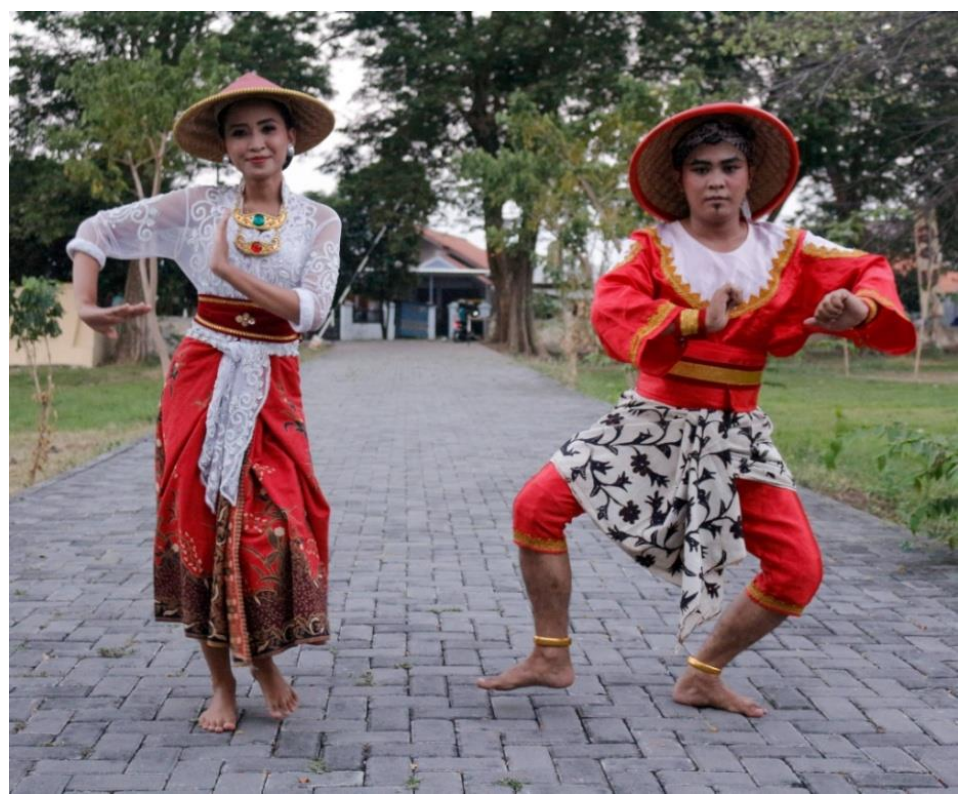

Foto 4.5 Lumaksono Ngracik

(Sumber: Devvi Lutfiana, 19 Mei 2017) 


\section{Penghubung}

Ragam gerak penghubung memiliki keindahan objektif saat disaksikan. Penghubung dilakukan secara berulang sebagai gerakan transisi. Kedua tangan penari putri dilontangkan ke samping kanan dan kiri secara bergantian dengan diikuti gerakan kaki yang diakhiri dengan jinjit. Pandangan penari putri mengikuti arah lontangan kedua tangan baik ke samping kanan maupun kiri. Penari putra mengangkat caping secara bergantian dan mengibaskan nya ke samping kanan dan kiri sambil berjalan. Gerakan Penghubung pada tari ini tidak mempunyai istilah khusus, hanya saja gerakan Penghubung pada tari Lenggang Pari menggambarkan aktifitas perjalanan petani menuju ke sawah.

Nilai keindahan pada ragam gerak penghubung dapat dilihat dari gerakan kedua tangan yang dilontangkan kanan kiri oleh penari putri dan kibasan caping oleh penari putra dilakukan dengan intensitas tenaga besar yang memberikan kesan penampilan tari bersemangat dan kuat. Tekanan pada kedua tangan penari putra dan putri menimbulkan keseimbangan gerak yang memberikan kesan tarian kuat. Rangkaian gerak penghubung dilakukan dengan ritme ajeg dengan penekanan tertentu energi yang berjalan dan isian gerak padat memberikan kesan tarian lincah. Pola gerak penghubung dengan fokus pandangan mengikuti gerakan tangan, arah hadap tubuh penari ke depan dan menggunakan level sedang membentuk garis asimetris yang memberikan kesan tarian dinamis dan menarik. 


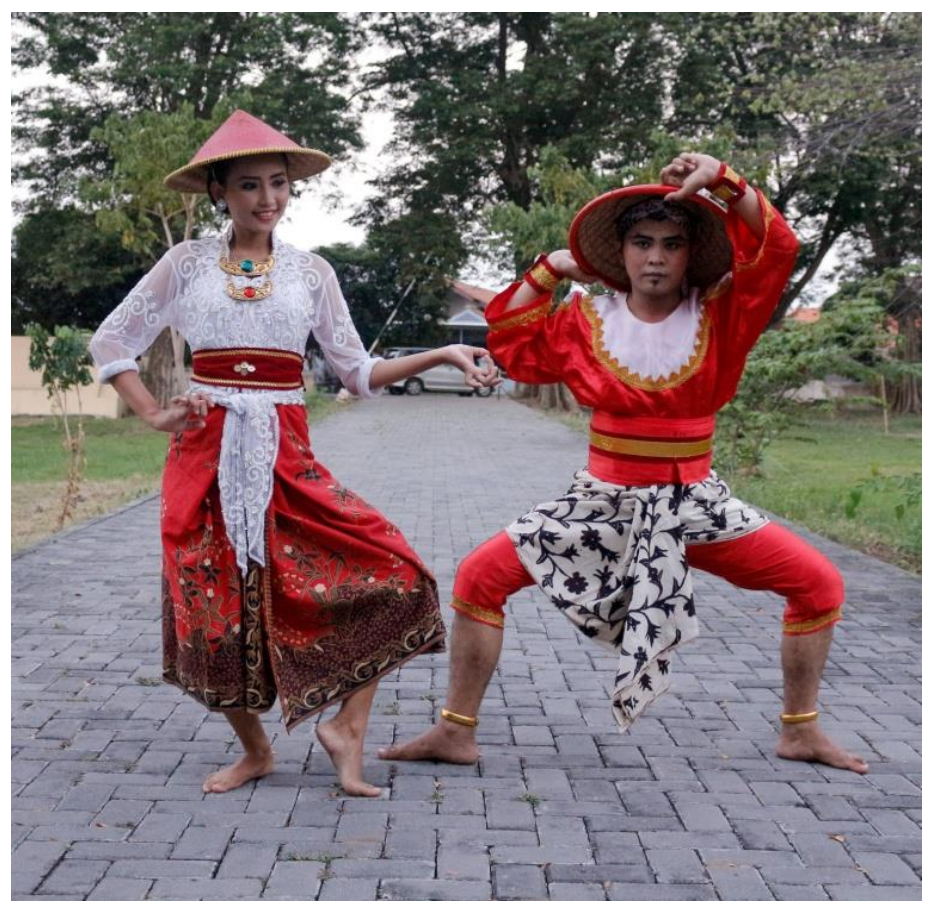

Foto 4.6 Penghubung

(Sumber: Devvi Lutfiana, 19 Mei 2017)

\section{Srisig}

Srisig dalam tari Lenggang Pari berbeda dengan gerakan srisig pada umumnya. Gerakan srisig pada tari Lenggang Pari dilakukan oleh kedua penari putra dan putri dengan gerakan kedua tangan memegang caping diluruskan ke arah depan sejajar dada penari putra dan diluruskan keatas kepala penari putri. Caping digerakan dengan kedua tangan dan pundak penari putra melakukan gerak oklak sehingga terlihat bergetar. Penekanan gerak ini pada gerakan berjalan cepat, penari putra dengan berjalan mundur sedangkan penari putri berputar dan mengejar penari putra sambil mengangkat caping lurus di atas kepala.

Ragam gerak srisig mempunyai nilai keindahan pada gerakan yang cepat memberikan kesan kewes (genit, centil) bagi penari putri dan bersemangat pada penari putra. Rasa kegairahan muncul pada saat kedua penari melakukan gerak 
srisig dengan intensitas tenaga yang besar dan tekanan pada pundak dengan gerak oklak menambah nilai estetis tari Lenggang Pari. Gerak srisig dilakukan dengan tempo cepat dan ritme ajeg dengan pengulangan gerakan yang sederhana terkesan sangat teratur. Fokus pandangan penari ke depan dangan arah hadap saling beradu wajah dan berada pada level sedang memberikan kesan tari yang lincah. Gerak srisig merupakan gerak saling mengisi antar penari putra dan putri dengan saling berhadapan menggambarkan interaksi penari melalui tatapan mata.

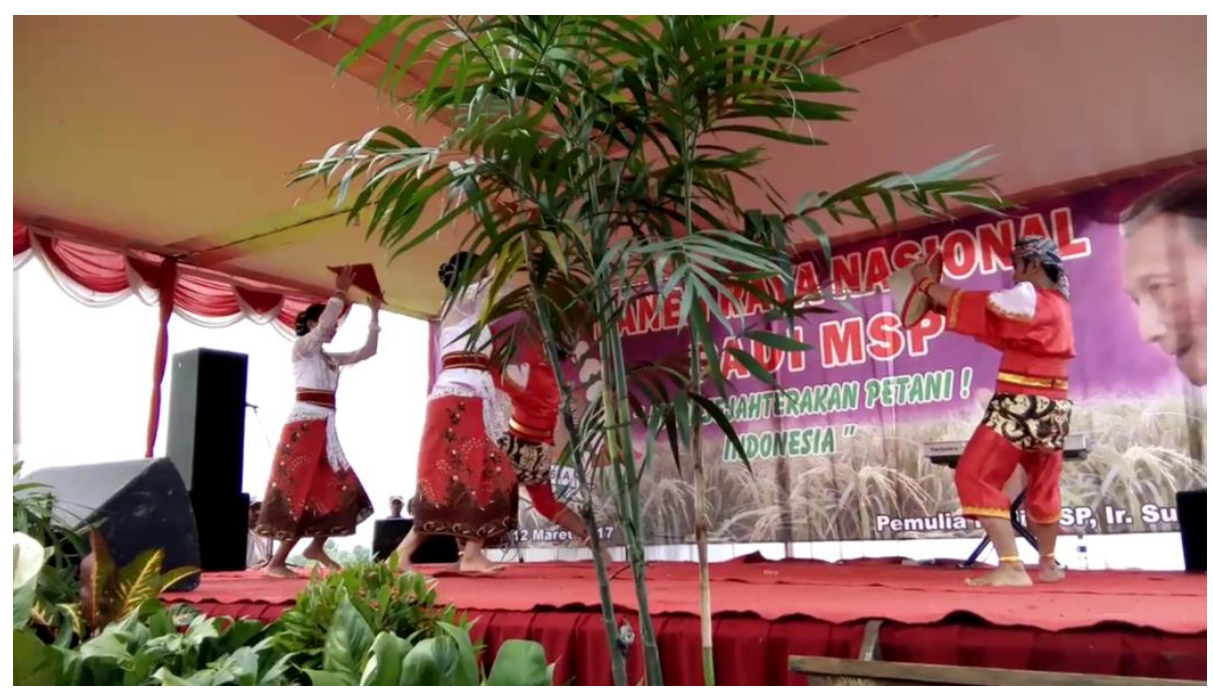

Foto 4.7 Srisig

(Sumber: Devvi Lutfiana, 12 Maret 2017)

\section{Nandur}

Gerak nandur menggambarkan aktifitas seorang petani dalam menanam padi. Penari putra berada di belakang penari putri dan berjalan seirama menunjukan ketertarikan untuk menjalin kedekatan, bersama-sama dan bergotong-royong melakukan gerakan nandur. Pada gerakan nandur posisi badan penari membungkuk dan berjalan menyamping dengan membuka lebar kaki kanan ke samping kanan tangan kanan menyilang ke bawah di depan kaki kiri, kaki kiri bergerak ke kanan menutup tangan kiri menyilang ke bawah di depan 
kaki kanan, kaki kanan kembali melangkah membuka lebar ke samping kanan kemudian kaki kiri mancat ke depan dan badan ditegakkan pandangan ke arah depan dengan posisi kedua tangan memegang caping di depan perut.

Nilai keindahan ragam gerak nandur dilakukan oleh putra dan putri dengan gerak saling mengisi. Pada saat bergerak dengan kelincahan kaki penari gerakan tersebut menggunakan intensitas tenaga yang besar memberikan kesan penampilan tari yang bersemangat dan kuat. Penggunaan tenaga yang lebih besar dilakukan pada saat badan penari pada posisi tegak untuk mencapai kontras dengan gerakan sebelumnya. Penggunaan tenaga yang teratur menimbulkan rasa keseimbangan. Gerak nandur penekanannya pada gerakan kaki yang cepat, seimbang, lincah dan terlihat kuat saat kaki kiri mancat ke depan. Keseimbangan gerakan juga nampak pada gerak-gerak tangan yang menyilang secara teratur dan menggambarkan gerakan petani menanam benih padi. Gerak tubuh pada ragam gerak nandur membentuk garis-garis diagonal dengan arah gerak ke samping kanan tubuh penari memberikan kesan tarian yang dinamis. Ragam gerak nandur dilakukan dengan tempo cepat dengan ritme ajeg sehingga isian gerak lebih padat dan teratur. 


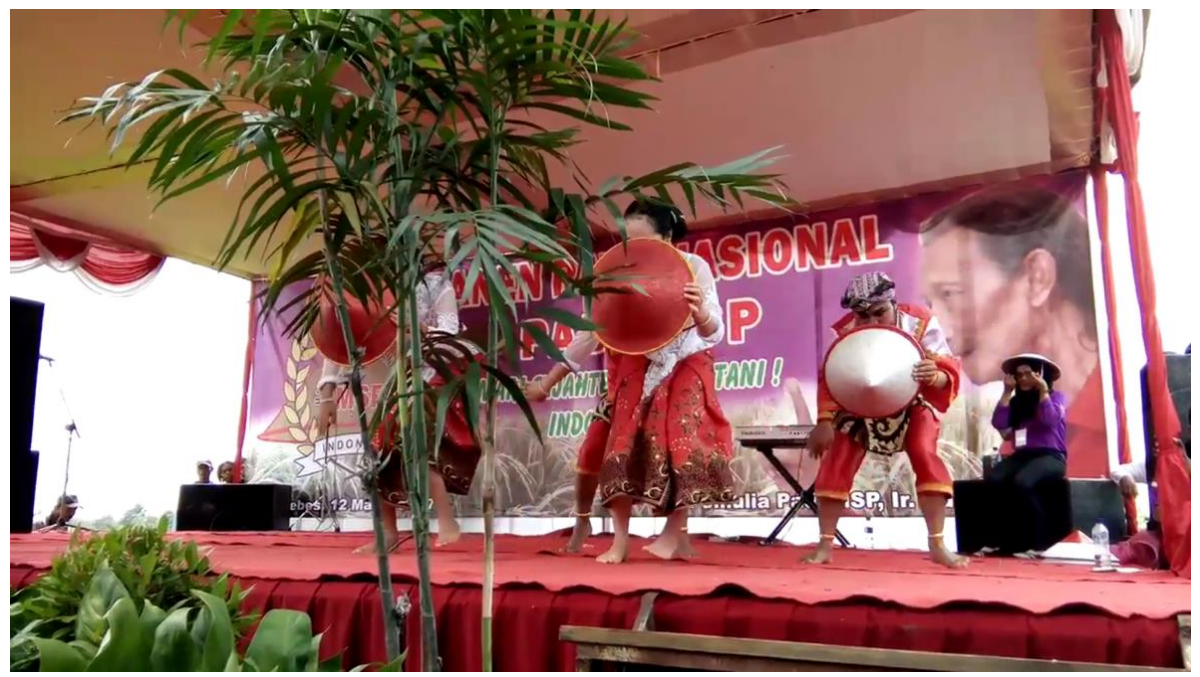

Foto 4.8 Nandur

(Sumber: Devvi Lutfiana, 12 Maret 2017)

\section{Ngusir Manuk}

Ragam gerak ngusir manuk dalam tarian ini mempunyai maksud seperti menggambarkan petani yang sedang mengusir burung dengan tali yang telah dihubungkan dengan kaleng-kaleng pada area ladang persawahan. Gerakan tersebut diwujudkan melalui gerak tepukan kedua tangan kemudian dikibaskan ke arah samping kanan dan kiri secara bergantian dengan sedikit loncat dan salah satu kaki diangkat. Gerak yang dilakukan penari putra bergerak menjauh dari penari putri dengan posisi badan mendhak bergerak melangkah ke samping kiri, kedua tangan mengangkat caping lurus di atas kepala, menggerakkan nya memutar ke arah kanan dan kiri serta diputar di depan dada. Kemudian berubah arah hadap dan melakukan gerakan dengan menggetarkan caping didepan dada dengan kedua tangan lurus dan kaki melakukan junjungan dengan lompatan secara bergantian kaki kanan dan kiri.

Nilai keindahan ragam gerak ngusir manuk terdapat pada peralihan tenaga yang dilakukan. Ketika penari putri berputar kemudian menepukan kedua tangan 
intensitas tenaga yang digunakan mengalun sehingga terkesan feminim, akan tetapi ketika gerakan diberikan tekanan kuat pada kaki kanan yang diangkat dan melompat, serta ayunan kedua tangan dari arah kanan ke kiri seolah-olah mendorong ke samping menimbulkan peralihan dari posisi badan tegap membungkuk kemudian tegap kembali memperlihatkan intensitas tenaga yang digunakan besar sehingga memberikan kesan penampilan tari yang bersemangat. Sedangkan pada penari putra intensitas tenaga yang digunakan kuat, adanya tekanan-tekanan pada kedua tangan dalam menggerakan caping secara cepat kemudian melakukan lompatan dengan junjungan kaki kanan dan kiri secara bergantian dan mampu menjaga keseimbangan tubuh pada satu tumpuan kaki. Kesan yang ditimbulkan adalah kesan tegas, gagah, kuat dan bersemangat.

Kualitas gerak kedua penari pada ragam gerak ngusir manuk bersifat serba menghentak cepat, kekuatan ekspresi wajah penari terlihat jelas dari pandangan matanya sehingga tarian menjadi hidup dan terkesan bersemangat. Pergerakan penari putra yang bergerak menjauh dari penari putri pada ragam gerak ngusir manuk menggambarkan rasa saling tolong-menolong dalam menjalankan tugas sebagai seorang petani yang diwujudkan melalui arah hadap penari yang bergantiganti. Figur kedua penari yang bergerak menciptakan desain di dalam ruang pentas dan adanya hubungan timbal balik antar gerak dan arah hadap dalam ruang pentas membangkitkan corak dan makna tarian. Garis-garis zigzag yang terbentuk oleh penari memberikan kesan tarian yang dinamis. Level yang digunakan pada ragam gerak ngusir manuk baik oleh penari putra maupun putri dari level sedang sampai level tinggi ketika gerakan melompatkan kaki. Ragam gerak ngusir manuk 
menggunakan ritme ajeng dengan tempo cepat sehingga gerakan terasa lebih aktif dan menggairahkan. Gerak dengan tempo cepat serta didukung suasana dan senggakan hoi memberikan kesan lincah, ramai dan berenergi pada ragam gerak ngusir manuk.

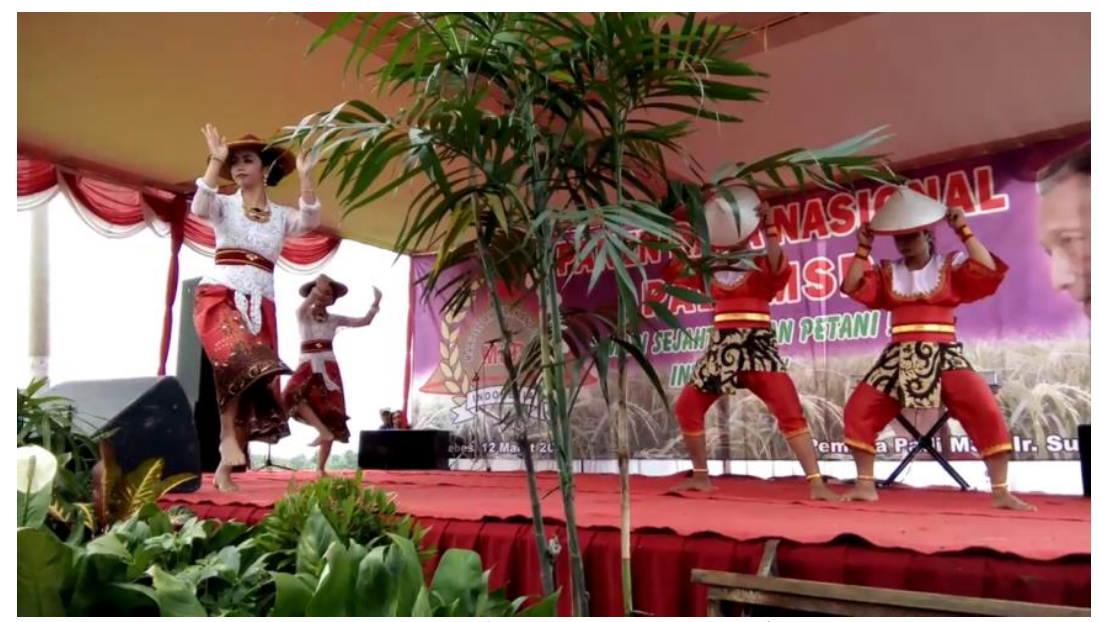

Foto 4.9 Ngusir Manuk

(Sumber: Devvi Lutfiana, 12 Maret 2017)

\section{Ngasoh}

Ragam gerak ngasoh menggambarkan keadaan istirahat atau berhenti beraktifitas yang dilakukan seorang petani. Penari putra dan putri mengangkat caping dari atas kepala dan kemudian diletakan di depan pinggul dengan posisi jongkok dan mendhak sebagai wujud berhenti beraktifitas. Ragam gerak ngasoh dilakukan dengan menggunakan intensitas tenaga yang mengalun sehingga terkesan fenimin pada penari putri dan terkesan tenang pada penari putra. Gerakannya tanpa tekanan berarti tenaganya merata sehingga menimbulkan kesan tari yang lemah lembut. Kualitas gerak penari bersifat ringan dan ekspresi penari ditonjolkan melalui gerak yang lemah lembut.

Nilai keindahan ragam gerak ngasoh juga dapat dilihat dari tempo yang lambat memberikan kesan lemah lembut dan tenang. Ritme yang digunakan pun 
tidak ajeg dari berjalan kemudian berhenti memberikan wujud penerapan dan pengendoran kekuatan selama durasi waktu yang dibutuhkan, isian gerak nya sedikit dibandingkan dengan ketukan maka memberikan kesan lemah lembut pada tarian. Garis yang terbentuk oleh penari simetris, sikap pause pada gerak ngasoh mewujudkan suatu desain ruang yang memberikan kesan gerakan tenang. Level tinggi digunakan penari putri pada saat gerakan jalan mengangkat caping, level sedang digunakan penari putri pada saat posisi jongkok. Sedangkan penari putra konsisten menggunakan level sedang. Perubahan level memberikan fungsi pada kualitas penari melalui ekspresi penari yang dapat ditangkap oleh penonton.

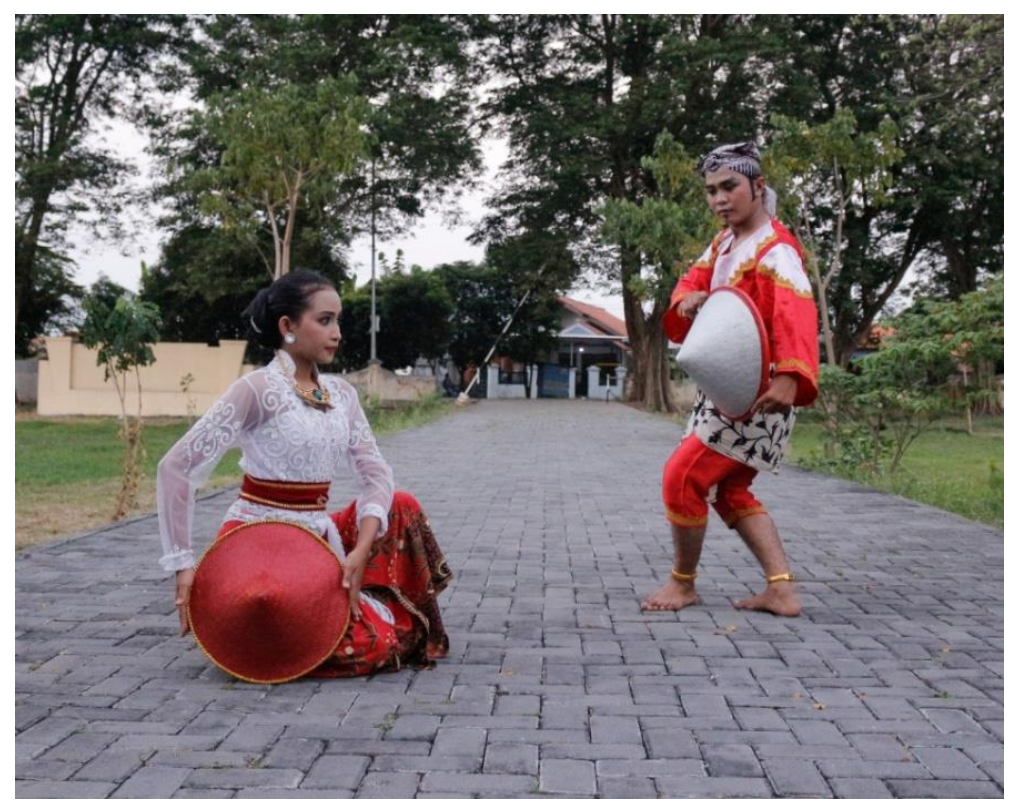

Foto 4.10 Ngasoh

(Sumber: Devvi Lutfiana, 19 Mei 2017)

\section{Mupuk Siram}

Ragam gerak mupuk siram pada tarian ini mempunyai maksud menggambarkan aktifitas petani yang sedang menabur pupuk tanaman padi sebagai obat penyubur tanaman padi dan pengairan di ladang persawahan. Pembagian gerak penari putra dan putri pada ragam gerak mupuk siram sangat 
jelas terlihat. Posisi gerak mupuk siram yang dilakukan penari putri, volume gerak lebar kedua kaki membuka lebar, posisi badan mendhak dan membungkuk, gerak bersifat menghentek dengan membolak balikkan kedua telapak tangan membuka dan menutup serta kaki bergerak geser ke arah kanan dengan tekanan gerak pada kaki yang menghentak.

Caping diangkat dari atas kepala kemudian digerakan dengan cara menggetarkan caping di depan wajah secara cepat dalam keadaan badan masih membungkuk dengan kedua kaki trecet ke arah kanan dengan fokus pandangan melihat kebawah. Sedangkan posisi gerak mupuk siram yang dilakukan penari putra dalam keadaan posisi badan mendhak, kedua tangan mengankat caping dan mengayunkan ke arah kanan dan kiri, membolak-balikan caping gerakan maju mundur.

Pada ragam gerak mupuk siram yang dilakukan oleh penari putra dan putri, nilai keindahan terdapat pada intensitas penggunaan tenaga yang besar memberikan kesan penampilan tari yang bersemangat pada penari putri dan kuat pada penari putra. Tekanan gerak penari putri difokuskan pada kedua pergelangan tangan dan sikap kaki ketika melakukan gerakan trecet. Tekanan gerak semacam ini berguna untuk membedakan pola gerak yang satu dengan pola gerak yang lain. Tekanan gerak penari putra difokuskan pada salah satu tangan ketika mengangkat caping lebih tinggi dari kepala. Tekanan gerak yang digunakan tinggi sehingga menimbulkan kesan kuat dan gagah. Ragam gerak mupuk siram dilakukan dengan tempo gerak cepat yang memberikan kesan lincah, ramai dan berenergi. Ritme gerak penari putri ajeg sehingga memberikan kesan lincah, sedangkan ritme gerak 
penari putra tidak ajeg ada frase pengendoran kekuatan gerak ketika mengangkat caping dan berpose. Kualitas gerak yang dihasilkan bersifat menghentak cepat dalam menuju titik akhir dari frase gerak oleh penari putri, dan mengalun pada penari putra. Volume gerak penari putri sedang sehingga memberikan kesan bersemangat. Volume gerak penari putra besar sehingga memberikan kesan gerak kuat.

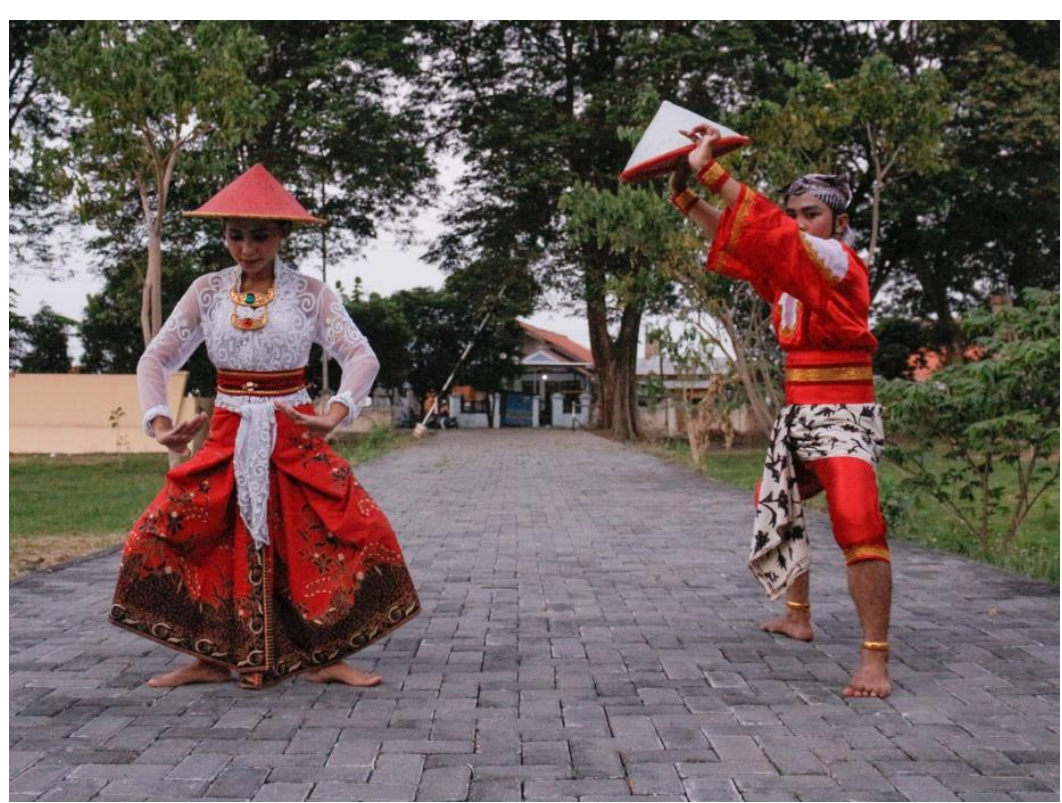

Foto 4.11 Mupuk Siram

(Sumber: Devvi Lutfiana, 19 Mei 2017)

\section{Dewi-dewian}

Ragam gerak dewi-dewian dalam tari Lenggang Pari mempunyai maksud untuk menyembah dan memberikan rasa hormat kepada sang pencipta, bersyukur atas rahmat yang telah diberikan berupa nikmat sehat dan mampu menyelesaikan prosesi penanaman padi. Perwujudan tersebut dilakukan melalui gerak penari putri diangkat oleh penari putra dan bergerak berjalan menyamping kemudian berputar saling berhadapan dengan pasangan penari yang lain. Penari putra menjaga keseimbangan dalam mengangkat penari putri dan berjalan. Penari putri 
melakukan proses menyembah dengan merentangkan dan menggerakan kedua tangannya di $u k e l$ kedalam maupun keluar. Kemudian penari putri diturunkan dari pundak penari putra, sikap kedua tangan menyatu dan ngrayung posisi badan mendhak. penari putra jengkeng dan melakukan proses sembahan sama hal nya dengan penari putri.

Nilai keindahan ragam gerak dewi-dewian dapat dilihat pada gerakan ketika penari putra mengangkat penari putri. Penari putra menggunakan intensitas tenaga besar sehingga memberikan kesan gerak yang kuat. Penari putri melakukan gerakan kedua tangan tanpa tekanan dan tenaganya merata sehingga menimbulkan kesan gerak yang lemah lembut. Arah pergerakan penari berputar dan saling berhadapan dengan pasangan penari yang lain menggambarkan adanya interaksi antar pasang penari untuk bersama-sama memanjatkan doa. Ritme gerak dipandu oleh syair yang dilantunkan oleh sinden, mengalun untuk memberi kesan tenang dan khusuk. Pada gerakan menyembah tempo gerak pelan dengan tenaga sedikit. Gerakan menyembah pada ragam gerak dewi-dewian mempunyai maksud untuk bersyukur akan nikmat dan rahmat yang diberikan oleh sang pencipta.

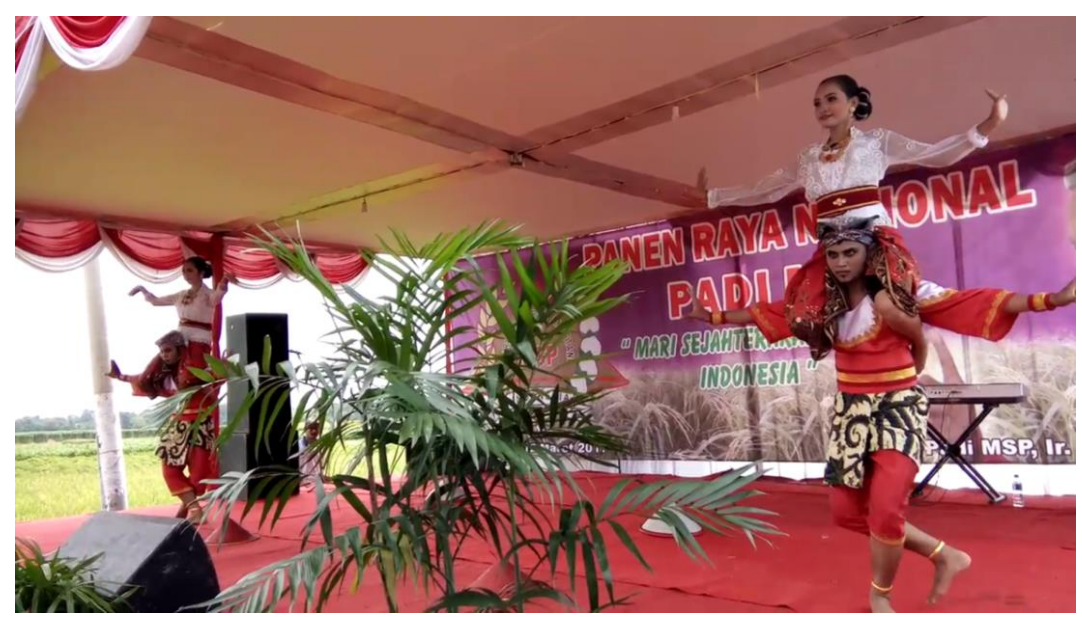

Foto 4.12 Dewi-dewian

(Sumber: Devvi Lutfiana, 12 Maret 2017) 


\section{Ngani-ani}

Ragam gerak ngani-ani pada tari Lenggang Pari mempunyai maksud seperti menggambarkan aktifitas panen raya dengan gerak memotong padi yang dilakukan petani. Proses ragam gerak ngani-ani oleh penari putri dengan berjalan mudur kebelakang dengan kedua tangan mengangkat caping yang dibalik terbuka, kaki penari menghentak-hentak sehingga terjadi gerak goyangan akibat dari langkah kaki ke kanan dan ke kiri. Kemudian tangan kiri memegang caping dan diletakan dipinggul kiri, tangan kanan melakukan gerakan mengayun dibawah caping, posisi badan mendhak dan mengencot, tangan kanan di ukel di atas caping, pandangan ke arah depan. Proses ragam gerak ngani-ani oleh penari putra dengan menyelehkan caping di bawah, posisi jengkeng naik keatas dengan membuka kedua tangan dan kaki, bergerak melangkah ke samping kanan dengan menyilangkan kedua tangan ke bawah dan kaki kiri menyilang di belakang kaki kanan. Kemudian merentangkan salah satu tangan dan melakukan gerakan oklak yang menimbulkan tubuh penari putra bergetar. Gerak menyilang pada penari putra menggambarkan aktifitas petani ketika menyibak padi untuk dipotong.

Nilai keindahan pada ragam gerak ngani-ani dapat dilihat dari intensitas penggunaan tenaga yang besar ketika bergerak memberikan kesan lincah, dinamis pada penari putri dan kuat pada penari putra. Cara berjalan penari putri menitikberatkan gerak encotan pada kaki. Tekanan pada kaki penari putri menggunakan tenaga yang teratur menimbulkan rasa keseimbangan. Gerak penari putra berjalan membuka dan menyilang dilakukan secara tegas, tekanan penggunaan tenaga tinggi memberikan kesan gerak yang kuat dan gagah. 
Penekanan gerakan terjadi pada hentakan tangan penari putra kemudian melakukan gerak oklak menggunakan tenaga yang kuat sehingga memunculkan kualitas gerak yang cepat dan menghentak memberikan kesan tarian kuat dan bersemangat. Tempo ragam gerak ngani-ani sedang memberikan kesan dinamis dengan ritme gerak yang ajeg sehingga isian gerak lebih padat memberikan kesan gerak yang lincah.

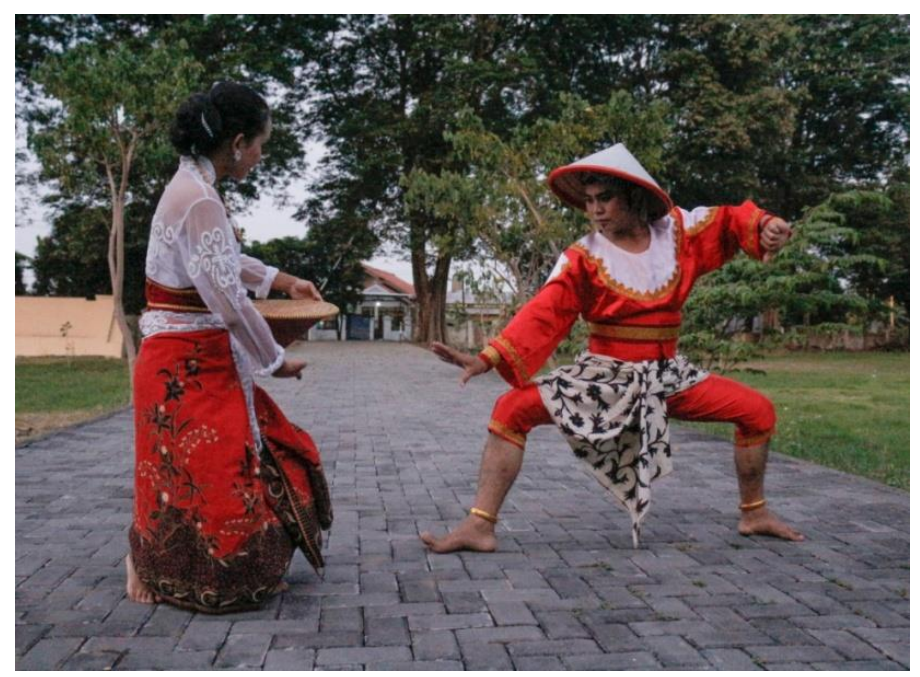

Foto 4.13 Ngani-ani

(Sumber: Devvi Lutfiana, 19 Mei 2017)

\section{Ndeplok}

Ragam gerak ndeplok pada tari Lenggang Pari menggambarkan aktifitas petani dalam menumbuk padi hasil panen dengan alat tradisional berupa lesung, gerakan tangan penari putri seperti mengangkat tumbukan dan menumbuk padi, sedangkan gerak penari putra menggambarkan rasa semangat dalam menumbuk padi. Proses gerak yang dilakukan penari putri dengan sikap tangan ngithing mengayunkan kedua tangan ke atas dan ke bawah secara bergantian dengan gerakan kaki mancat kanan dan kiri, tolehan wajah mengikuti pergerakan kedua tangan ketika berada di posisi bawah setara pinggang. Proses gerak yang 
dilakukan penari putra dengan melakukan gerakan onclang junjungan kaki kanan dan kiri secara bergantian dan berjalan berputar, kedua telapak tangan ngepel diayunkan ke arah kanan dan kiri secara bergantian, jengkeng mengambil caping dengan kedua tangan dan diletakan diatas kepala lalu melakukan gerakan oklak.

Pada ragam gerak ndeplok nilai keindahan dilihat dari intensitas penggunaan tenaga yang besar oleh penari sehingga menimbulkan kesan gerak yang kuat dan bersemangat pada penari putra serta lincah pada penari putri. Tekanan yang tinggi pada kedua tangan penari putra serta junjungan kaki memberikan kesan kuat dan gagah. Tekanan teratur pada kedua tangan penari putri dan gerak kaki mancat memberikan kesan gerak yang seimbang. Arah pergerakan penari putra dengan variasi berputar bersama dan saling mengelilingi kemudian penambahan aksi loncat memberikan kesan gerak yang dinamis dan bersemangat. Arah pergerakan penari putri dengan level sedang membentuk garis simetris memberikan kesan gerak tenang dan sederhana. Ragam gerak ndeplok menggunakan tempo cepat yang memberikan kesan lincah, ramai dan berenergi. Ritme gerak ajeg dengan isian gerakan lebih padat dibanding dengan ketukan memberikan kesan lincah.

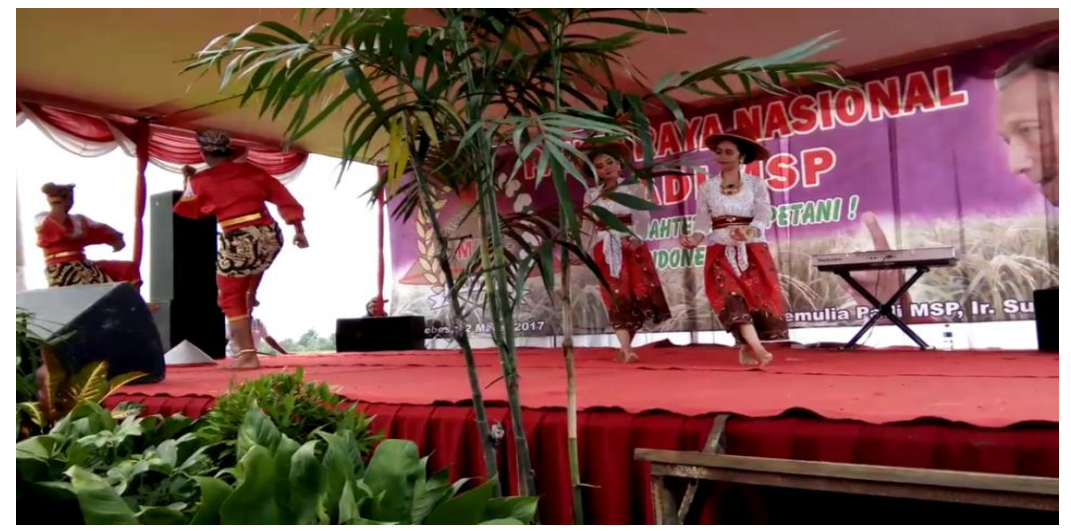

Foto 4.14 Ndeplok

(Sumber: Devvi Lutfiana, 12 Maret 2017) 


\section{Lembehan Leyeh}

Ragam gerak lembehan leyeh pada tari Lenggang Pari menggambarkan seperti aktifitas beristirahat dengan menghentakan tangan yang telah digunakan untuk menumbuk padi dan melepas rasa lelah yang dirasakan petani. Proses gerak lembehan leyeh pada penari putra dan putri hampir sama yaitu dengan melakukan penthangan pada kedua tangan ke arah samping kanan dan kiri secara bergantian. Penari putri melakukan penthangan pada kedua tangan dengan sikap tangan ngrayung digerakan secara bergantian ke kanan dan kiri dengan posisi kaki menyilang maju dan menyilang mundur, tolehan wajah mengikuti arah gerakan kedua tangan. Proses gerak lembehan leyeh pada penari putra dengan melakukan penthangan tangan dengan sikap tangan ngepel dan kambeng, posisi badan mendhak melakukan gerakan oklak kemudian ngglebag arah depan belakang secara bergantian diakhiri dengan entragan pada kaki.

Nilai keindahan ragam gerak lembehan leyeh dapat dilihat pada pola lantai yang digunakan adalah menyudut lintasan gerak penari putri keduanya adalah maju dan mundur, sedangkan penari putra nmengikuti ke arah samping seperti saling tarik menarik antar penari putra. Motif gerak ini menggambarkan sepasang muda mudi yang berusaha untuk melepas penat secara bersama dan mengajak pasangannya untuk berkumpul bersama dan mengenal satu sama lain. Penggunaan tenaga dengan intensitas tenaga yang mengalun memberikan kesan feminim pada penari putri dan tenang pada penari putra. Tekanan gerak penari putra dan putri terdapat pada kedua tangan yang menghentak dengan tenaga teratur menimbulkan rasa keseimbangan pada gerak. Tempo gerak lembehan leyeh menggunakan 
tempo lambat sehingga memberi kesan lemah lembu, ritme gerak yang ajeg dengan isian gerak lebih sedikit dibanding ketukan memberikan kesan yang lemah lembut.

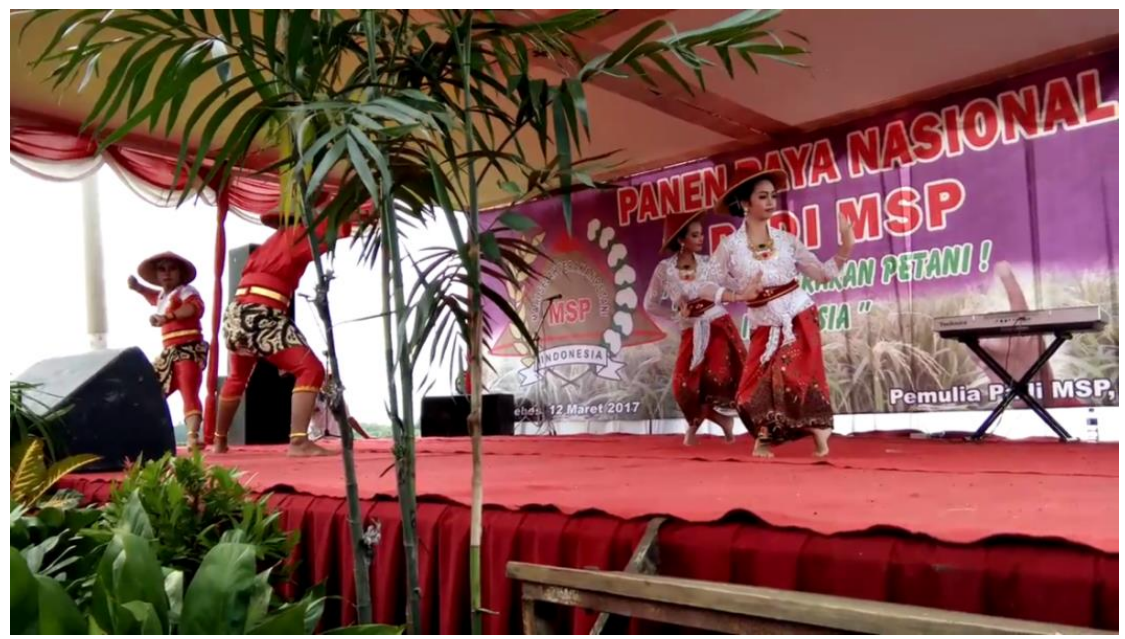

Foto 4.15 Lembehan Leyeh

(Sumber: Devvi Lutfiana, 12 Maret 2017)

\section{Nampi}

Ragam gerak nampi pada tari Lenggang Pari mempunyai maksud seperti menggambarkan aktifitas petani mengayak atau membersihkan beras yang telah ditumbuk. Proses ragam gerak nampi yang dilakukan oleh penari putra dan putri mempunyai motif gerak yang sama. Caping dilepas dan diangkat dengan kedua tangan yang kemudian dibalik posisinya sehingga caping terbuka, kedua tangan mengayunkan caping ke arah atas dan bawah dengan posisi badan mendhak kaki kanan mancat dan dihentakan bersamaan dengan gerakan mengayunkan caping. Kedua tangan lalu memutar caping di depan badan dari arah kanan ke kiri, caping dilemparkan ke sisi kanan penari lalu ditangkap oleh penari lain, gerakan tersebut dilakukan berulang-ulang. Penari putra dan putri berjalan dengan menghentak- 
hentakan kaki kanan dan kedua tangan mengayunkan caping ke arah atas dan bawah.

Nilai keindahan ragam gerak nampi dapat dilihat dari pola lantai yang digunakan yaitu saling mengelilingi satu sama lain dari empat arah penjuru, dua pasang penari putra dan putri saling berhadapan dan melakukan interaksi dengan menangkap caping yang masing-masing dilempar oleh antar penari. Arah pergerakan penari yang diam ditempat memberikan kesan tenang dan kompak dalam bekerjasama saling bahu membahu. Tempo gerak yang digunakan sedang sehingga penggunaan tenaga mengalun memberikan kesan gerakan fenimin pada penari putri dan tenang pada penari putra. Tekanan gerak difokuskan pada hentakan-hentakan kedua tangan dalam menggerakan caping, hentakan kaki kanan dengan penggunaan tenaga yang teratur menimbulkan kesan gerak seimbang. Ritme gerak nya tidak ajeg adanya pause gerak menunggu musik menimbulkan isian gerak tidak padat sehingga memberi kesan tarian lemah lembut.

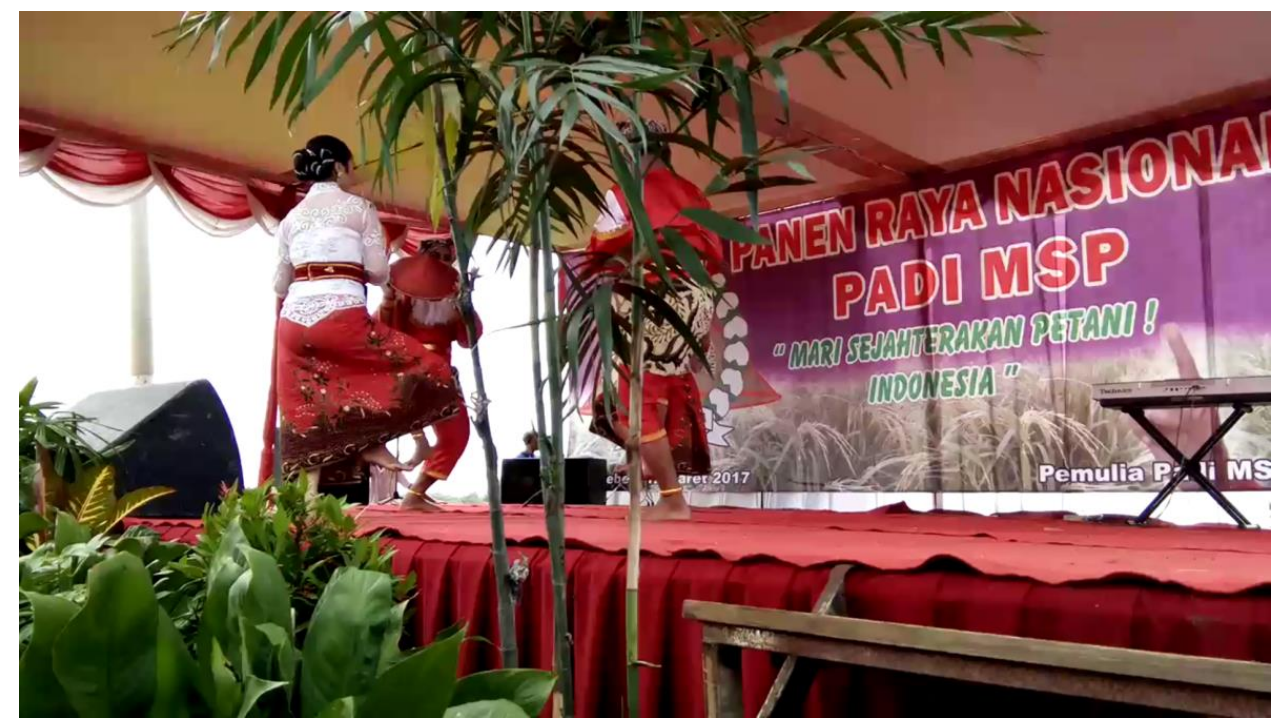

Foto 4.16 Nampi

(Sumber: Devvi Lutfiana, 12 Maret 2017) 


\section{Seak}

Ragam gerak seak pada tari Lenggang Pari mempunyai maksud seperti menggambarkan kebahagiaan petani setelah panen raya dilakukan dengan gerak jogedan dan ayunan tangan sebagai bentuk rasa kepuasan terhadap hasil panen padi. Penari putra dan putri menari bersama, penari putra berada di belakang penari putri, penari putra sesekali berjalan maju dan mundur di sisi kanan penari putri.

Proses ragam gerak seak yang dilakukan penari putri dengan tangan kiri memegang caping yang terbuka diletakan di pinggang kiri, tangan kanan mengayun kebelang dan ke depan sisi kanan dengan sikap tangan ngrayung, posisi badan mendhak, posisi kaki berjalan ke samping kanan kiri bergantian sehingga menimbulkan efek pinggul bergoyang. Gerak bergoyang pada motif ini merupakan akibat dari langkah kaki ke kanan dan ke kiri. Kedua tangan mengenakan caping di atas kepala, kedua tangan penari putri ditekuk dan melakukan motif gerak lembehan putri dengan menggerakan telapak tangan mendorong ke samping kanan dan kiri dengan gerakan telapak tangan berlawanan arah hadap antara punggung tangan dan telapak tangan sejajar pundak. Ayunan kedua tangan berganti dengan sikap tangan ngrayung digerakan di depan dada saling menyilang bergantian.

Proses gerak ragam gerak seak yang dilakukan penari putra dengan kedua tangan mengenakan caping, kedua tangan direntangkan dan diayunkan ke atas bawah bergantian, posisi kaki kanan menyilang di depan kaki kiri, kaki kanan dan kiri menghentak bergantian, motif gerak jogedan penari putra pada ragam gerak 
seak dilihat dari gerakan tangan penari putra mendorong ke arah bawah samping kanan dan kiri diikuti kaki kanan dan kiri yang bergeser secara bergantian. Keduan tangan penari putra membuka melakukan gerakan seperti menyerok ke arah bawah kemudian mendorong ke arah atas, posisi kaki berjalan maju double step kanan ke depan dan double step kiri ke belakang bergantian.

Nilai keindahan ragam gerak seak pada tari Lenggang Pari dapat dilihat dari intensitas penggunaan tenaga yang teratur pada saat bergerak memberikan kesan gerak lemah lembut. Jogedan penari putra mempunyai maksud seperti menunjukan kepada penari putri tentang gambaran alam sekitar ladang persawahan. Penggunaan tenaga yaang besar pada dorongan penari putra memberikan kesan gerak yang kuat dan bersemangat. Keberagaman bentuk jogedan antar penari putra dan putri memberi kesan gerak yang menarik dan bergairah sebagai bentuk penuangan ekspresi.

Arah pergerakan penari putra dan putri dengan variasi gerak maju dan mundur, ke depan dan ke belakang, ke kanan dan kiri dilakukan secara simetris. Kesimetrisan ini menimbulkan citra kuat karena desain ruangnya yang seimbang. Gerak mengalun dengan tempo lambat pada ayunan tangan penari memberi kesan lemah lembut pada tarian. Ritme gerak yang ajeg dengan pengulangan gerak yang sederhana mempunyai rasa keteraturan pada gerak yang menimbulkan kesan tenang, lemah lembut dan halus pada tarian. Pola-pola pengulangan ini mencerminkan kesederhanaan dan kuat. 


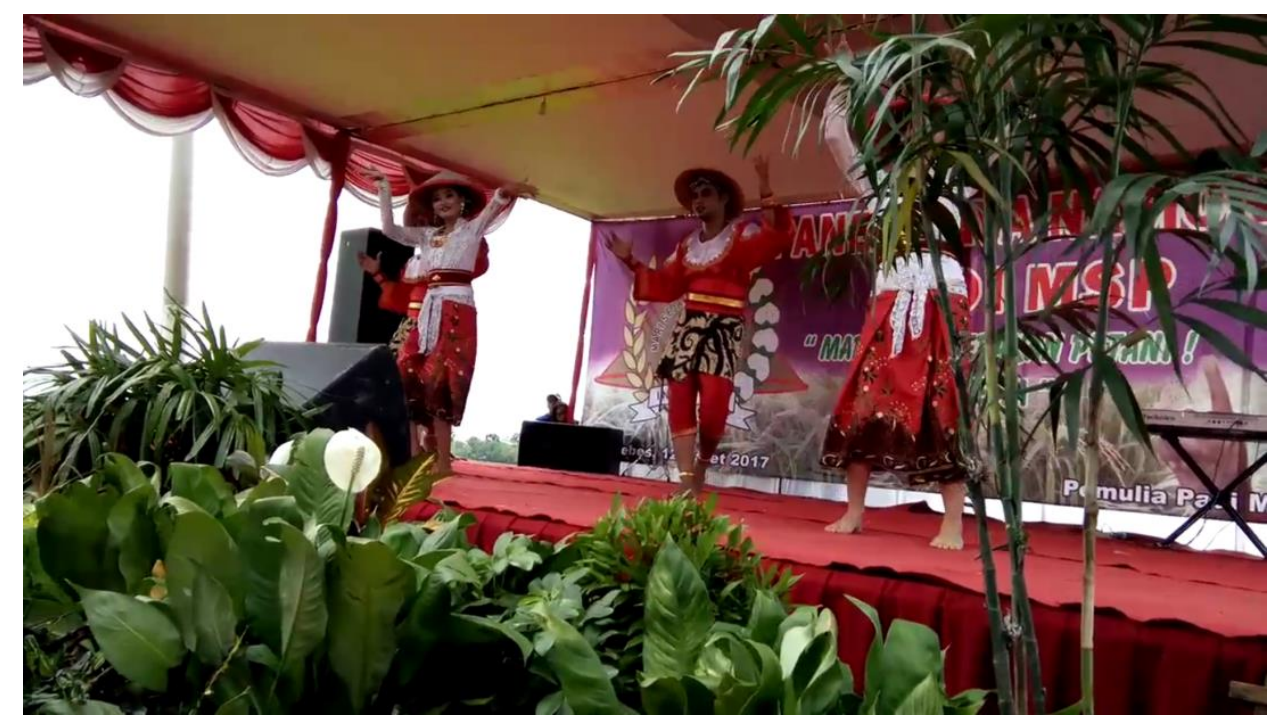

Foto 4.17 Seak

(Sumber: Devvi Lutfiana, 12 Maret 2017)

Keberadaan penari putra dan putri pada tari Lenggang Pari menunjukan kebersamaan, kerukunan dan kesuburan yang utuh. Kebanyakan gerak penari putra dan putri berbasis gerak yang sama namun perbedaan gender mengakibatkan perbedaan volume serta perbedaan pengembangan geraknya. Volume gerak penari putri lebih sempit dari pada volume gerak penari putra.

Motif-motif gerak pada tari Lenggang Pari sederhana karena dilihat dari struktur tarian dan pengulangan geraknya. Pengulangan gerak dibutuhkan untuk menegaskan hal-hal tertentu agar dapat dimaknai oleh penonton. Pengulangan gerak lumaksono ngracik, penghubung dan ngasoh ditonjolkan untuk dapat menegaskan keunikan dari bentuk tari Lenggang Pari. Motif gerak tari Lenggang Pari kuat karena setiap motif gerak dilakukan dengan simetris dua sisi yakni kanan dan kiri atau maju dan mundur.

Pola lantai pada pertunjukan tari Lenggang Pari pada saat penelitian yang dilakukan oleh peneliti sangat sederhana. Pola lantai penari sudah terstruktur dari 
bentuk tariannya yaitu secara berpasangan sehingga menimbulkan interaksi antar penari lebih kuat. Pola lantai dalam tari Lenggang Pari dalam setiap pertunjukanya tidak lah sama, akan tetapi penari dapat menempatkan variasi pola lantai secara bebas berdasarkan ruang dan jumlah penarinya serta tidak mengurangi esensi tariannya. Pola lantai pada pertunjukan tari Lenggang Pari dibuat untuk memperindah pertunjukan.

Nilai keindahan pola lantai pada pertunjukan tari Lenggang Pari terdapat pada beberapa variasi bentuk pola lantai yang dibuat dengan variasi arah hadap penari dari sisi kanan dan kiri ataupun ke depan dan ke belakang sehingga memberikan kesan keseimbangan pada tarian. Bentuk pola lantai dengan garis horisontal membentuk garis lurus ke samping memberikan kesan lembut. Bentuk pola lantai dengan garis vertikal membentuk garis lurus dari depan ke belakang memberikan kesan sederhana dan kuat. Pada pertunjukan tari Lenggang Pari hampir semua arah pergerakan penari dilakukan secara simetris kanan dan kiri sehingga menimbulkan kesan keseimbangan pada desain ruangnya.

\subsubsection{Penari}

Penari adalah seseorang yang menarikan tari Lenggang Pari lengkap dengan menggunakan rias dan busana tari Lenggang Pari sehingga membentuk suatu pertunjukan tari yang utuh. Tari Lenggang Pari merupakan tari pasangan penari putra dan putri yang ditarikan secara berkelompok, minimal dua pasangan. Untuk menjadi penari pada tari Lenggang Pari seseorang baik putra maupun putri harus mempunyai niat belajar yang sungguh-sungguh. Untuk usia seorang penari tari Lenggang Pari dilakukan dari usia remaja hingga dewasa. 
Pada penelitian yang dilakukan kali ini pertunjukan tari Lenggang Pari dilakukan oleh empat orang penari, terdiri dari dua penari putri dan dua penari putra. Keempat penari tersebut merupakan siswa-siswi Sanggar Seni Perwitasari yang mulai menginjak usia dewasa dan merupakan anak didik pilihan yang kemampuan menarinya sudah sangat baik, mempunyai kemampuan dasar gerak tari Jawa serta bakat untuk meguasai materi tari lenggang Pari melalui proses latihan, disana ada materi-materi gerak yang membutuhkan kemampuan khusus dan penyesuaian dari kebiasaan yang dipelajari oleh anggota sanggar kemudian beradaptasi ke tari Lenggang Pari dengan berbagai gerakan yang memiliki tempo dari sedang sampai tinggi yang memang membutuhkan tekhnik khusus.

Nilai keindahan penari nampak pada kualitas seorang penari saat melakukan sebuah pertunjukan tari. Kualitas seorang penari pada tari Lenggang Pari baik putri maupun putra berhasil tercapai dengan kemampuan penghayatan dan ekspresi yang sesuai pada setiap ragam geraknya. Keindahan penari pada tari Lenggang Pari juga dilihat dari jenis kelamin, penari putri memberikan kesan feminim sedangkan penari putra memberikan kesan maskulin, keteraturan gerak serta kepekaan rasa dari penari putri dan putra memberikan kualitas tari yang mampu menggugah intuisi para penghayat. Konsep mengenai putra dan putri adalah konsep dwi karsa yang berarti kesatuan dua unsur kehendak dalam kehidupan. Keindahan penari putri nampak pada ekspresi wajah dengan senyuman memberi kesan lembut, serta gerakan pinggul memberikan kesan lincah dan atraktif. Keindahan penari putra nampak pada kondisi jasmani yang menunjukan 
kebugaran sehingga mampu menunjukan kualitas gerak dengan ekspresi yang sesuai pada setiap ragam geraknya.

\subsubsection{Ekspresi wajah/polatan}

Ide, bentuk dan gaya gerak menjadi sebuah kesatuan yang utuh dalam suatu konsep karya tari. Gerak merupakan sebuah media penuangan ekspresi yang dapat memuat berbagai macam kemungkinan keberagaman tak terbatas. Tanpa adanya keberagaman bentuk tersebut menjadi datar, kurang menarik dan kurang sempurna untuk ditangkap maknanya. Dalam usia yang sama dengan jenis kelamin berbeda tentu memiliki karakter dan sifat pembawaan yang berbeda pula. Bentuk tari Lenggang Pari merupakan interaksi penari putra dan putri. Interaksi tersebut menimbulkan berbagai macam ekspresi yang dapat dilihat dan diserap makna nya oleh penonton. Ekspresi tersebut juga tidak terlepas dari iringan tariannya.

Nilai keindahan ekspresi wajah dalam Tari Lenggang Pari diwujudkan dalam suatu bentuk ekspresi yang akan diserap dengan persepsi indera penikmatnya, dalam pertunjukannya adanya interaksi antar penari menimbulkan ekspresi melalui mimik wajah. Ekspresi muncul dari gerak-gerak yang dipolakan dalam tari Lenggang Pari. Tari Lenggang Pari merupakan tarian yang ekspresif. Pandangan mata menyapu ke arah penonton. Penari menuangkannya dalam mimik wajah dan penghayatan gerak seperti tersenyum. Ada kalanya gerak itu dengan ritme cepat memuat banyak sekali ekspresi gerak namun ada kalanya lembut penuh dengan penghayatan irama tari. 
Pengulangan gerak tari Lenggang Pari dilakukan untuk menegaskan halhal tertentu agar dapat dimaknai oleh penonton, pengulangan tersebut membantu penonton untuk menangkap gerak yang ingin ditonjolkan dan menegaskan keunikan dari tari Lenggang Pari seperti pada gerak lumaksono ngracik, penghubung, ngasoh dan dewi-dewian. Pada gerak lumaksono ngracik mimik wajah penari dengan senyuman memberikan kesan bersemangat, sedangkan pada gerak ngasoh mimik wajah penari datar dan menunduk memberi kesan lelah. Pada gerakan dewi-dewian menunjukan perasaan yang khikmat menyembanh kepada Tuhan dan perasaan berserah diri dengan menengadahkan tangan keatas dan mimik wajah memohon.

\subsubsection{Tata Rias dan Busana}

Tata rias dan busana dalam pertunjukan tari Lenggang Pari juga sangat diperlukan untuk menunjang penampilannya. Tata rias wajah dalam tari Lenggang Pari menggunakan rias korektif untuk penari putri dan rias karakter untuk penari putra. Tata rias rambut pada penari putri menggunakan cemara yang dibentuk sanggul bundar dan kecil yang diberikan aksesoris sebagai pengikatnya, untuk tata rias rambut penari putra hanya diberikan ikat. Untuk tata busana yang digunakan disesuaikan dengan jenis kelamin pada penarinya. Untuk lebih jelasnya tata rias wajah, tata rias rambut dan tata busana dalam tari Lenggang Pari secara utuh dapat dijelaskan sebagai berikut.

\subsection{Tata Rias Wajah}

Tata rias wajah merupakan seni memperindah wajah dengan menggunakan alat-alat kosmetik yang dapat mempertegas karakter peran yang sedang 
diperankan. Tata rias wajah pada tari Lenggang Pari merupakan rias panggung yang diciptakan untuk menunjang penampilan seorang penari di atas panggung, sehingga menimbulkan daya tarik dan kepekaan rasa pada penontonnya. Untuk mewujudkan suatu riasan panggung yang dapat mempertegas karakter seorang penari dibutuhkan alat-alat kosmetik dan bahan-bahan yang digunakan beserta keterangan untuk merias wajah penari.

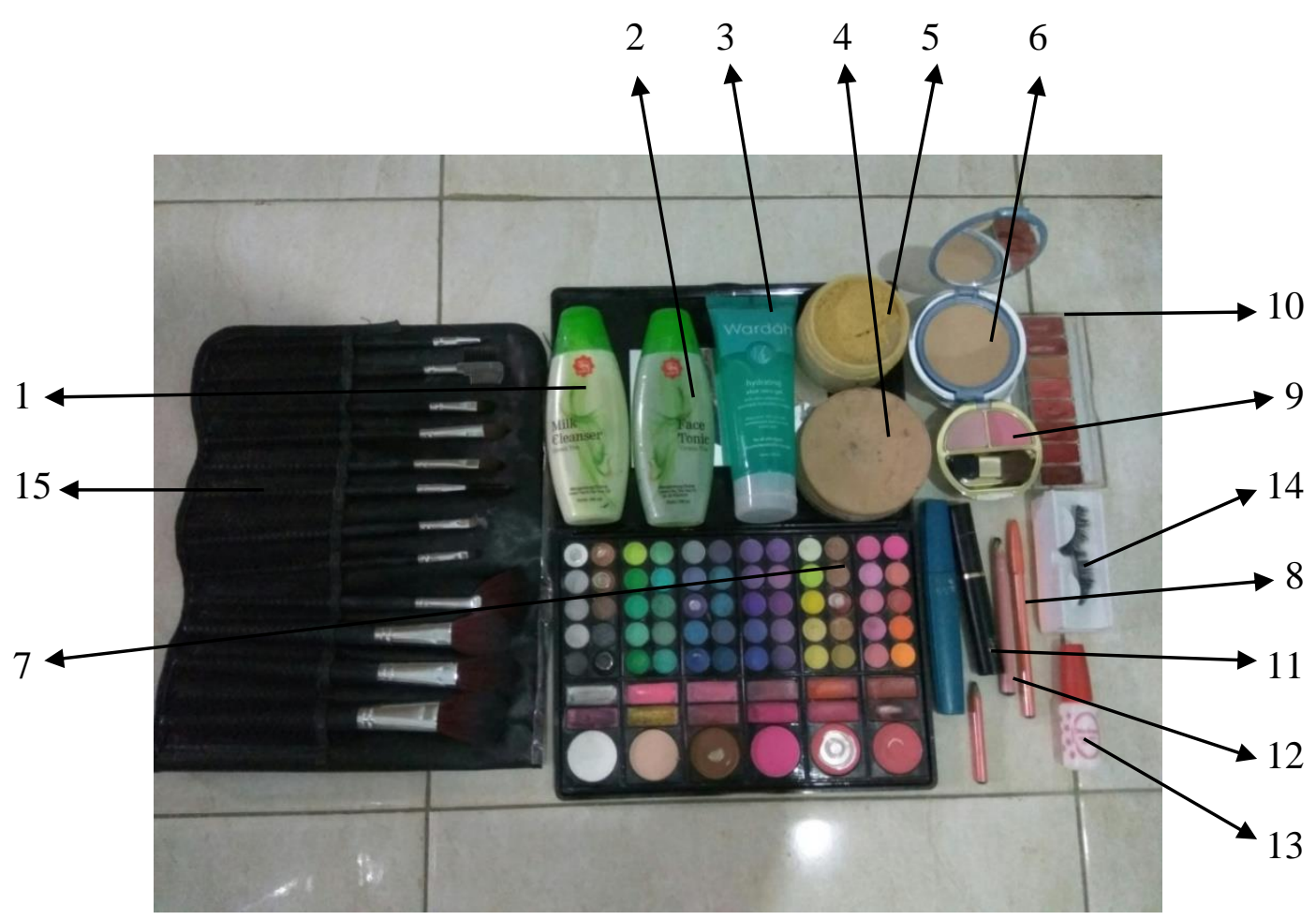

Foto 4.18 Alat dan Bahan Makeup

(Sumber: Devvi Lutfiana, 19 Mei 2017)

Foto 4.18 menunjukan gambar dari alat dan bahan rias wajah yang digunakan pada tari Lenggang Pari, antara lain: 1) Milk cleanse, 2) Face tonic, 3) Pelembab, 4) Foundation, 5) Bedak tabur, 6) Bedak Padat, 7) Eyeshadow, 8) Pensil Alis, 9) Blush on, 10) Lipstik, 11) Eye liner cair, 12) Eye liner padat, 13) Lem bulu mata, 14) Bulu mata palsu, 15) Satu seat kuas makeup. 
Kegunaan alat-alat kosmetik dan bahan yang digunakan dalam tata rias wajah tari Lenggang Pari dapat dijelaskan sebagai berikut:

1. Milk cleanser: untuk membersihkan kotoran-kotoran yang menempel di wajah,sebelum wajah di make-up.

2. Face tonic: untuk membersihkan sisa-sisa susu pembersih yang masih menempel di wajah.

3. Pelembab: untuk memberikan kelembapan pada kulit, dan agar make-up dapat menempel di kulit secara sempurna.

4. Alas bedak / foundation: untuk memberikan efek halus pada kulit wajah dan menjadikan make up tahan lama serta dapat menutupi pori-pori dan flek kurang baik.

5. Bedak tabur: untuk memberikan warna penyegaran dan menghilangkan minyak dari foundation.

6. Bedak padat: berguna untuk memberikan kesan wajah lebih halus dan bersinar, serta melekatkan dan mengawetkan make up.

7. Eyeshadow: pewarna kelopak mata, memberikan efek bayangan pada mata agar terlihat lebih bulat dan tajam, dan bayangan pada hidung agar terlihat mancung.

8. Pensil alis: untuk memberi ketegasan pada alis.

9. Blush on: untuk memberi perona pada pipi..

10. Lipstik: untuk memberi warna pada bibir

11. Eyeliner cair: untuk membuat kesan garis kelopak mata atas lebih tajam

12. Eyeliner padat: untuk membuat kesan garis bawah mata lebih tajam 
13. Lem bulu mata: untuk menempelkan bulu mata palsu pada kelopak mata

14. Bulu mata palsu: untuk memperindah mata dan memberikan kesan lebih nampak pada bulu mata itu sendiri.

15. Satu seat kuas makeup: untuk memulaskan bahan-bahan makeup pada setiap bagian-bagian wajah.

Tahapan yang dilakukan untuk merias wajah penari putri dan putra pada tari

Lenggang Pari sebagai berikut:

1. Milk cleanser dituangkan pada telapak tangan dan dioleskan merata pada seluruh wajah dan leher kemudian dibersihkan dengan menggunakan tisue.

2. Tuang face tonic pada kapas lalu ditepuk-tepuk ke seluruh bagian wajah dan leher yang telah dibersihkan dengan milk cleanser.

3. Wajah dan leher diberi pelembab secara merata, tunggu beberapa saat sampai pelembab meresap pada kulit.

4. Wajah dan leher diberi foundation secara merata dengan menggunakan puff.

5. Kemudian beri bedak tabur pada wajah dan leher dengan tone warna sesuai dengan kulit penari putri maupun putra dan ditambah dengan bedak padat disapukan pada wajah secara merata.

6. Merapikan dan membentuk alis penari putri dengan menggunakan pensil alis berwarna coklat yang dibaurkan dengan warna hitam, serta alis penari putra dengan pensil alis warna hitam pekat dengan model alis putra alus luruh.

7. Menggunakan eyeshadow pada kelopak mata dengan menyesuaikan warna busana yang digunakan oleh penari putri dan eyeshadow coklat tua untuk penari putra. 
8. Menggunakan bulu mata palsu yang diberi lem bulu mata dan ditempelkan pada bulu mata penari putri.

9. Menggunakan eye liner cair di atas bulu mata untuk mempertegas garis kelopak mata pada penari putri.

10. Menggunakan eye liner padat pada bawah mata penari putri dan putra untuk mempertegas garis bawah mata sehingga terlihat lebih tajam.

11. Menggunakan blush on dengan kuas untuk menjadikan pipi penari terlihat lebih merona.

12. Membentuk godeg dengan menggunakan pensil alis berwarna hitam pekat pada pelipis penari putra dan jenggot pada dagu penari putra.

13. Tahap terakhir yaitu menggunakan lipstik berwarna merah pada bibir penari putri agar terlihat cantik dan menawan, serta garis bibir pada penari putra.

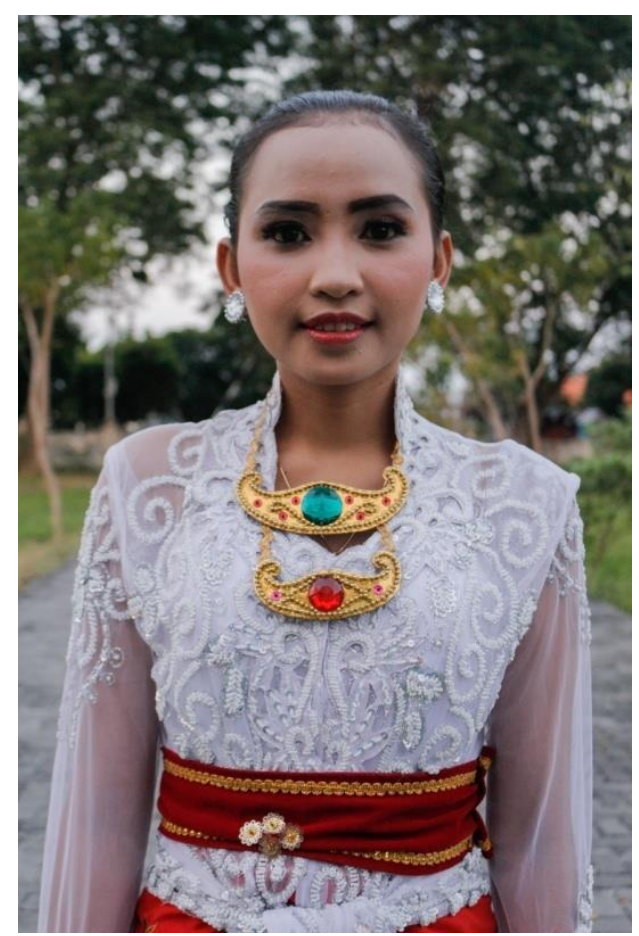

Foto 4.19 Tata Rias Wajah Penari Putri Tari Lenggang Pari (Sumber: Devvi Lutfiana, 19 Mei 2017) 

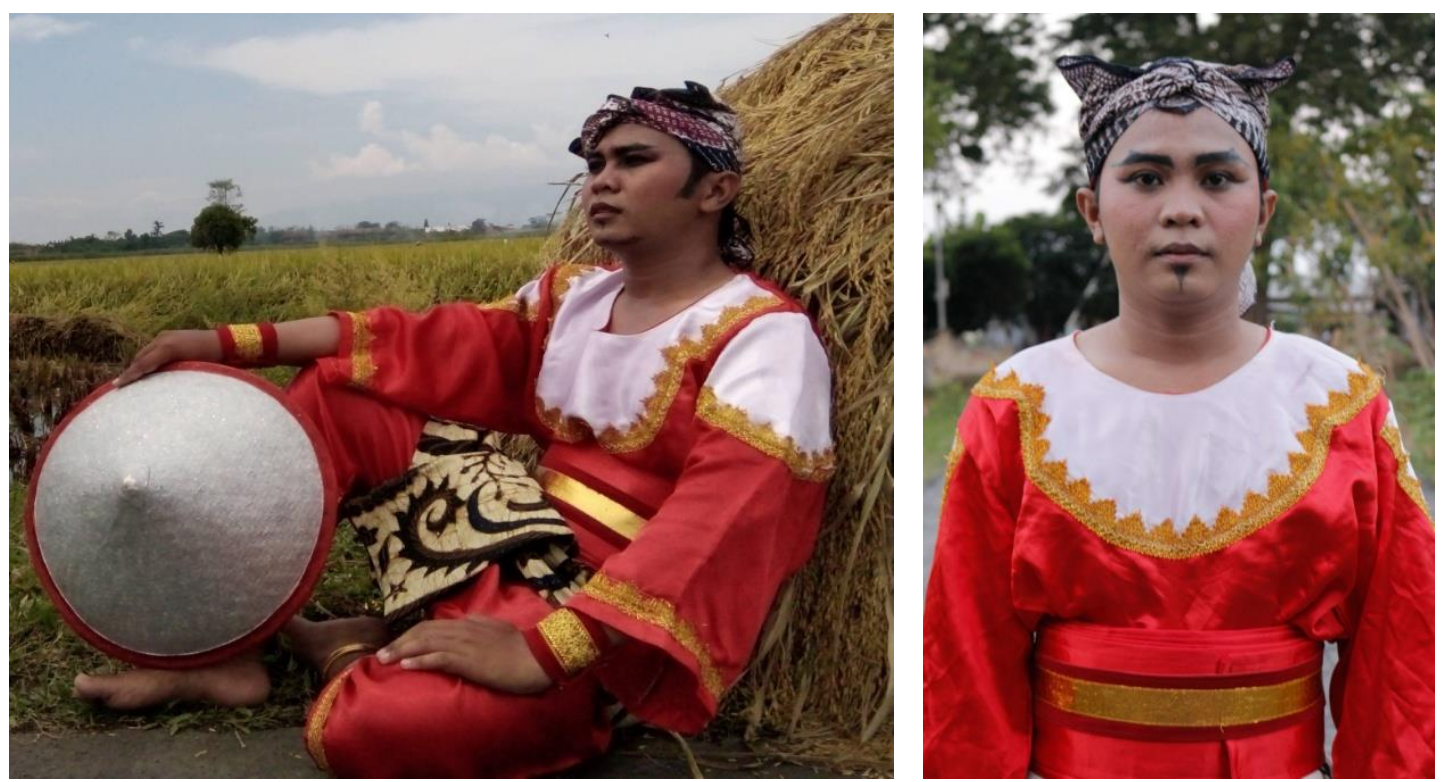

Foto 4.20 Tata Rias Wajah Penari Putra Tari Lenggang Pari (Sumber: Devvi Lutfiana, 19 Mei 2017)

Nilai keindahan tata rias wajah dalam pertunjukan tari Lenggang Pari nampak pada kesatuan yang utuh dari bagian-bagian yang dirias baik mata, hidung, pipi, bibir dan wajah secara keseluruhan. Rias wajah yang dipakai oleh penari putri dalam pertunjukan tari Lenggang Pari memiliki nilai keindahan pada pemelihan warna yang cerah dan menyala seperti pada eyeshadow merah yang dibaurkan dengan warna kuning emas, blush on berwarna merah, pensil alis coklat yang dibaurkan warna hitam memberi kesan tegas dan lipstik merah memberi kesan canti, segar dan bersemangat. Lain halnya dengan rias wajah pada penari putra dalam pertunjukan tari Lenggang Pari, penggunaan eyeshadow berwarna coklat dan abu-abu memberikan kesan natural pada kelopak mata penari namun lebih tegas garis kelopak matanya, penggunaan pensil alis berwarna hitam dengan model alis putra alus luruh serta godeg dan jenggot buatan menjadikan wajah penari putra lebih berkarakter. 


\subsection{Tata Rias Rambut}

Tata rias rambut penari putra maupun putri dalam pertunjukan tari Lenggang Pari menggunakan cemara dan ikat kepala. Tata rias rambut untuk penari putri menggunakan cemara yang diberi aksesoris dan dikaitkan serta dililitkan pada rambut asli yang telah dirapikan dan dicepol. Penggunaan cemara pada rambut penari putri yang dibentuk sanggul cepol menggambarkan kesederhanaan kehidupan seorang petani. Penggunaan ikat kepala pada penari putra selain sebagai aksesoris juga menggambarkan semangat juang kehidupan petani dalam mensejahterakan kehidupan melalui kegiatan bertani.

Tata rias rambut penari putri dengan menggunakan cemara digunakan terlebih dahulu dengan cara, rambut disisir rapi dan diikat membentuk cepol kecil dengan tinggi kurang lebih lima sentimeter dari tengkuk. Pengaplikasiannya dengan menggunakan sisir, hairspray, karet, jepit biting dan harnal. Setelah itu, cemara diberi aksesoris dan dililitkan kemudian dikaitkan diantara ikatan rambut asli, rambut cemara diputar dan dibentuk sanggul sederhana. Berikut ini dapat dilihat beberapa aksesoris yang digunakan pada tatanan rambut penari putri.

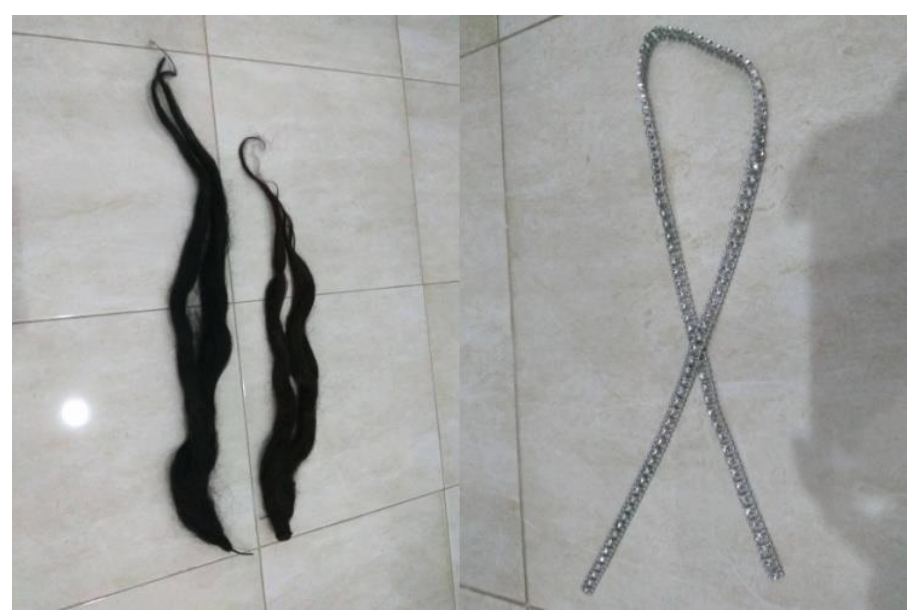

Foto 4.21 Cemara dan aksesoris

(Sumber: Devvi Lutfiana, 18 Mei 2017) 
Foto 4.21 adalah cemara dan aksesoris yang digunakan pada tata rias rambut penari putri dalam pertunjukan tari Lenggang Pari. Berikut adalah hasil akhir dari tata rias rambut penari putri.

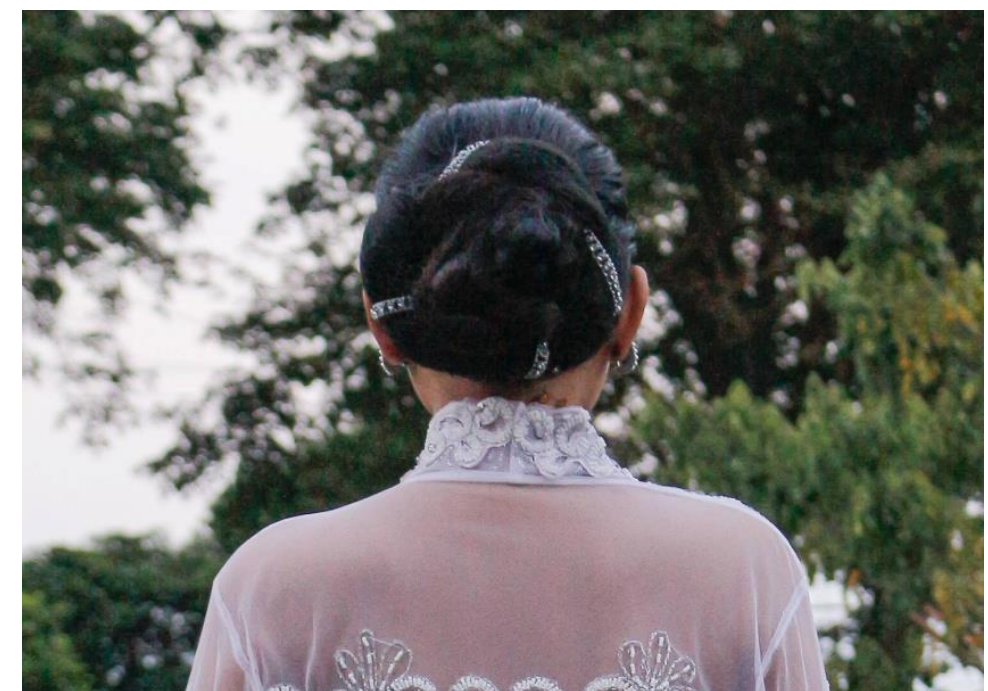

Foto 4.22 Tata Rias Rambut Penari Putri Tari Lenggang Pari (Sumber: Devvi Lutfiana, 19 Mei 2017)

Tata rias rambut yang digunakan penari putra dalam pertunjukan tari

Lenggang Pari sangatlah sederhana dengan menggunakan iket udaran.

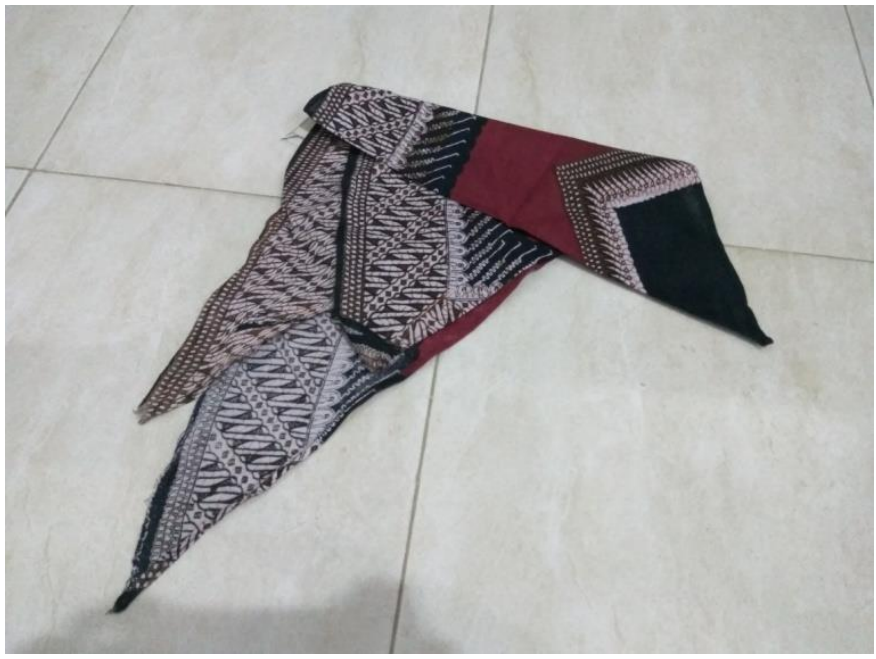

Foto 4.23 Aksesoris Iket Udaran

(Sumber: Devvi Lutfiana, 18 Mei 2017) 


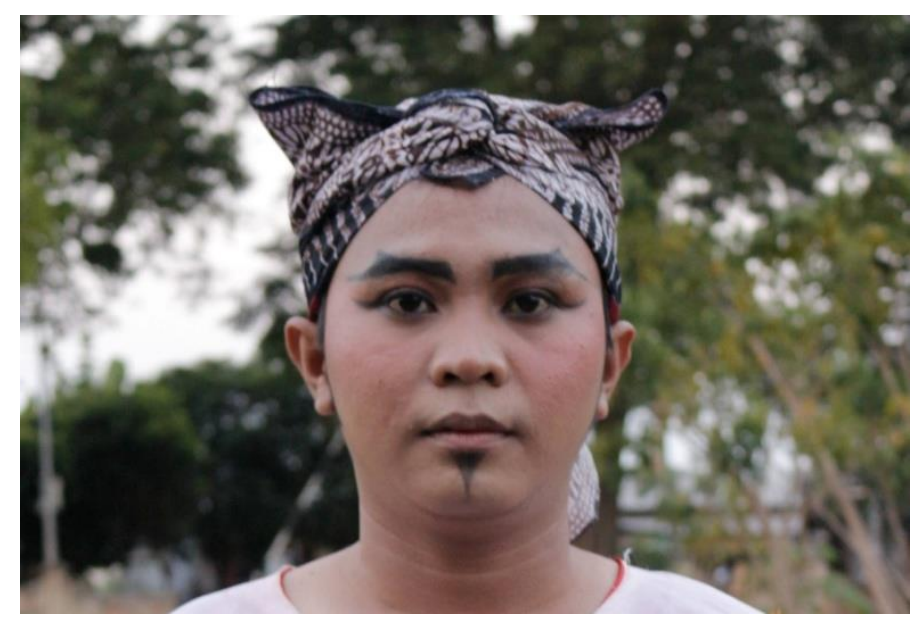

Foto 4.24 Tata Rias Rambut Penari Putra Tari Lenggang Pari (Sumber: Devvi Lutfiana, 19 Mei 2017)

Foto 4.23 dan foto 4.24 menunjukan aksesoris ikat kepala yang digunakan dalam tata rias rambut penari putra dan hasil dari penggunaan aksesoris ikat kepala pada tata rias rambut penari putra dalam pertunjukan tari Lenggang Pari.

Setelah dijelaskan apa saja yang digunakan dan tata cara untuk tata rias rambut penari dalam pertunjukan tari Lenggang Pari. Nilai keindahan tata rias rambut penari putri dan putra dalam pertunjukan tari Lenggang Pari dapat dilihat dari kesederhanaan penggunaan aksesoris yang menunjang. Hal ini menunjukan bahwa kesederhanaan mampu memberikan nilai keindahan tersendiri melalui hasil karya tata rias rambut penari putri, sanggul sederhana yang terbentuk memberikan kesan pada penari yang sederhana dan anggun. Sedangkan pada penari putra penggunaan ikat kepala memberikan kesan gagah.

\subsection{Tata Busana}

Busana yang digunakan oleh penari putri dalam pertunjukan tari Lenggang Pari terdiri dari streples atau kamisol, kain jarik, kebaya putih, sabuk, giwang atau 
anting-anting dan kalung. Dapat dijelaskan bagian-bagian busana penari putri yang digunakan dalam pertunjukan tari Lenggang Pari sebagai berikut:

\section{Kain Jarik}

Kain jarik berbentuk lembaran persegi panjang kemudian ditekuk seperempat bagian dan masih memanjang cukup untuk menutup bagian perut sampai dibawah lutut atau betis. Bahannya terbuat dari kain berwarna dasar merah dengan motif bungan coklat merambat. Fungsinya sebagai penutup dan melingkari dari bagian perut hingga dibawah lutut atau betis. Cara penggunaannya setelah kain ditekuk memanjang seperempat bagian dari lebar kain, kain dililitkan dipinggul dengan kedua ujung kain berada didepan pusar kemudian ditekuk atau diwiru lebar membentuk rok, setelah rapi kemudian stagen dililitkan ke pinggang agar lebih kuat.

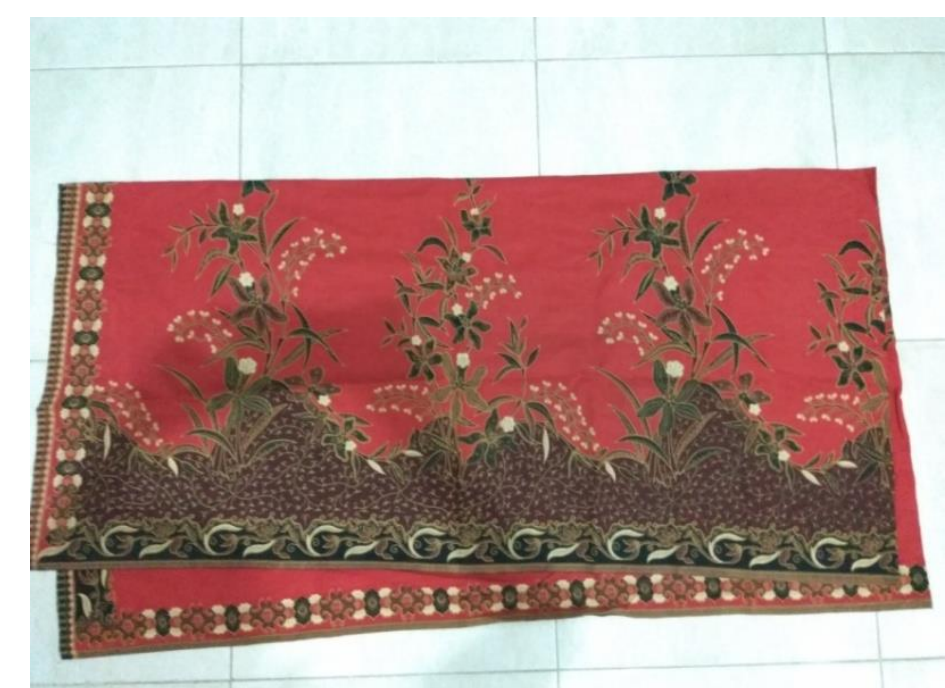

Foto 4.25 Kain Jarik Penari Perempuan Tari Lenggang Pari (Sumber: Devvi Lutfiana, 18 Mei 2017)

\section{Streples atau kamisol}

Streples atau kamisol merupakan pakaian dalam yang berbentuk kemben. Bahannya dari kain dengan tulang-tulang agar membentuk badan. Fungsinya yaitu 
agar badan nampak bagus dan berbentuk. Cara penggunaannya yaitu dipakai pada badan sebagai kemben sebelum menggunakan kostum inti.

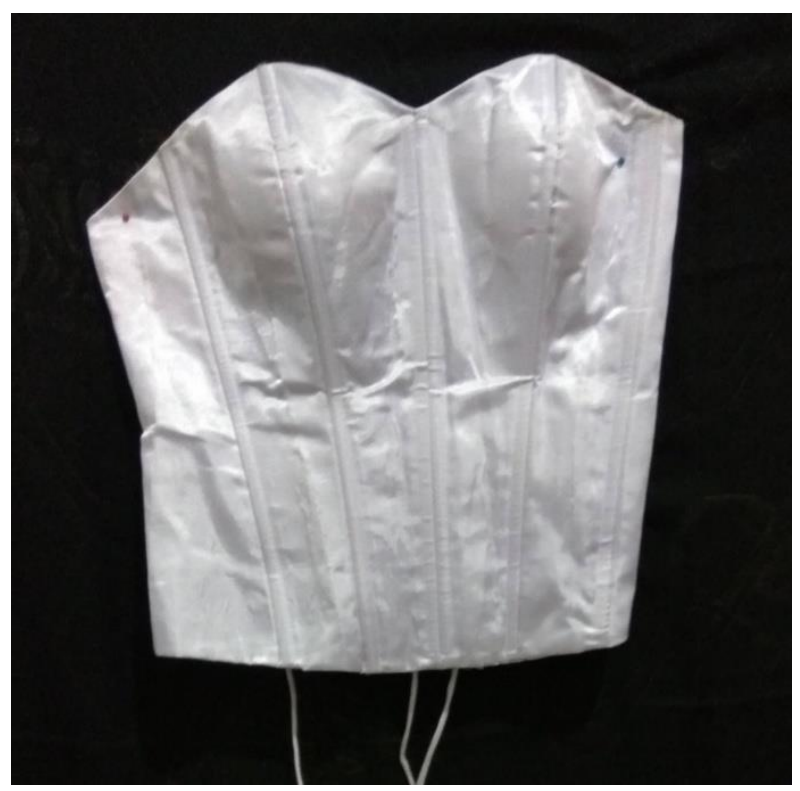

Foto 4.26 Streples atau Kamisol Putih Penari Putri Tari Lenggang Pari (Sumber: Devvi Lutfiana, 18 Mei 2017)

\section{Kebaya}

Baju atasan yang dipakai yaitu dengan menggunakan baju kebaya berukuran lengan panjang dari bahan kain brokat berwarna putih. Fungsinya sebagai baju atasan. Cara penggunaannya yaitu dengan di pakai seperti menggunakan baju biasa dan dikancing bagian depan kemudian lengan ditekuk seperempat. 


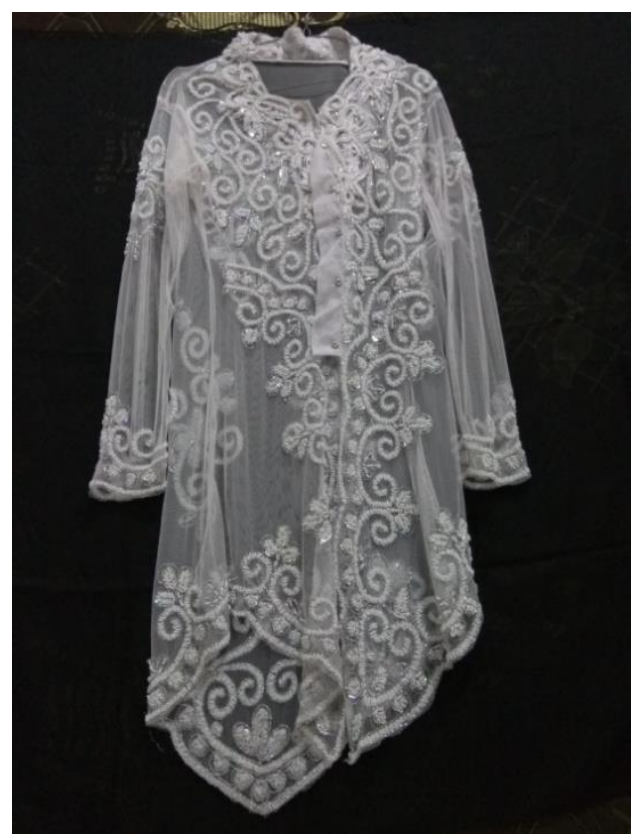

Foto 4.27 Kebaya Putih Penari Putri Tari Lenggang Pari (Sumber: Devvi Lutfiana, 18 Mei 2017)

\section{Slepe atau sabuk}

Slepe atau sabuk berbentuk seperti ikat pinggang namun agak lebar. Bahannya terbuat dari kain berwarna merah dengan garis tepi kuning dan beberapa motif bulatan-bulatan berwarna kuning yang membentuk bunga. Fungsinya sebagai pemanis baju kebaya yang digunakan. Cara penggunaannya di lingkarkan dipinggang dengan menggunakan peniti atau jarum pentul.

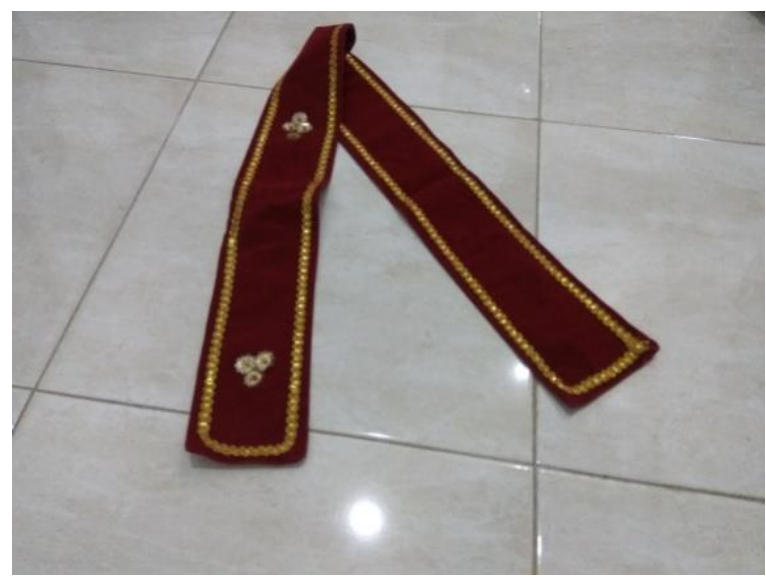

Foto 4.28 Sabuk Merah Penari Putri Tari Lenggang Pari (Sumber: Devvi Lutfiana, 18 Mei 2017) 


\section{Giwang atau anting-anting}

Giwang atau anting-anting merupakan aksesoris yang berbentuk lingkaran dengan mute-mute dipinggir dan bagian tengah berkilau, terbentuk dari permata imitasi. Fungsinya sebagai penghias telinga. Cara penggunaannya yaitu dengan di jepitkan pada daun telinga bawah.

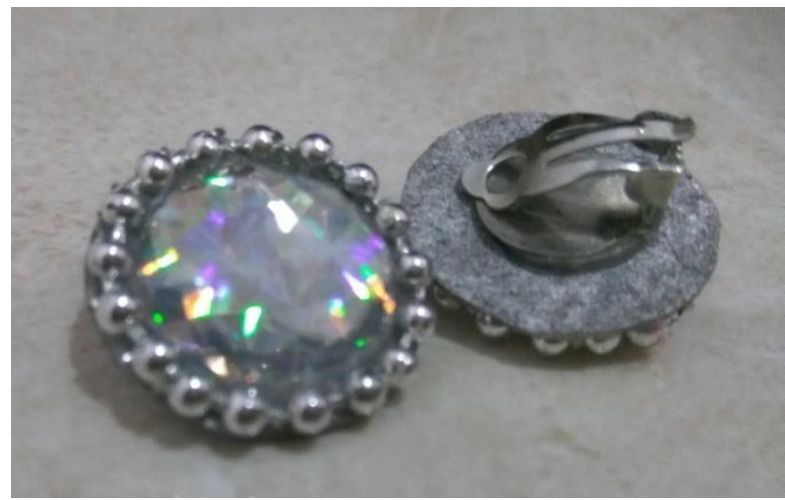

Foto 4.29 Giwang atau anting Penari Putri Tari Lenggang Pari (Sumber: Devvi Lutfiana, 18 Mei 2017)

\section{Kalung}

Kalung merupakan aksesoris yang digunakan melingkar di leher dan berfungi sebagai penghias leher. Cara penggunaanya yaitu dengan mengkaitkan kedua sisi tali di bagian belakang leher.

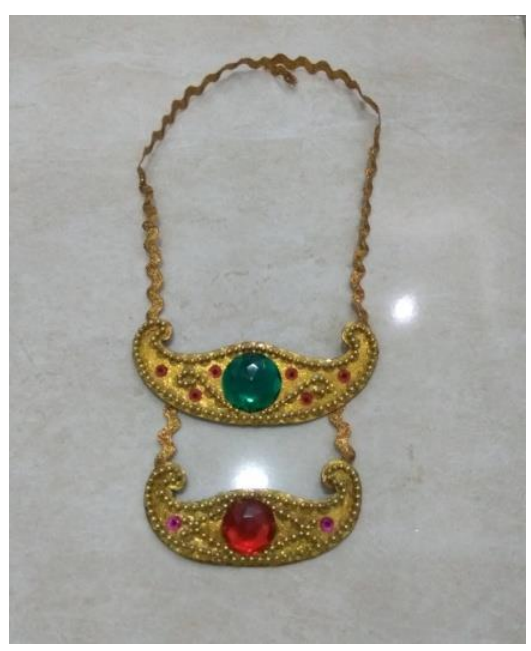

Foto 4.30 Kalung Penari Putri Tari Lenggang Pari

(Sumber: Devvi Lutfiana, 18 Mei 2017) 
Adapun tata cara pemakaian busana penari putri dalam pertunjukan tari Lenggang Pari sebagai berikut:

1. Memakai kain jarik yang telah ditekuk seperempat bagian kain, kain digunakan menutupi bagian belakang terlebih dahulu, kemudian kedua ujung kain dipertemukan didepan pusar, masing-masing ujung kain ditekuk kedalam membentuk wiru pada bagian kanan dan kiri. Setelah wiru terbentuk kedua bagian ujung kain di satukan ditengan-tengan dibawah pusar, kaitkan keduanya dengan menggunakan beberapa peniti dan ditali menggunakan tali berwarna putih.

2. Menggunakan streples atau kamisol berwarna putih yang dililitkan di badan dan diberi peniti agar kencang.

3. Memakai baju kebaya berwarna putih seperti memakai baju pada umumnya dan di kancing, setelah dirapikan ambil kedua ujung kebaya dan diikatkan simpul dibawah pusar, kemudian pada bagian lengan ditekuk sampai tiga kali sehingga pergelangan tangan terlihat.

4. Menggunakan sabuk berwarna merah dengan melingkarkan dibagian pinggang atau diatas simpul tali dari baju kebaya kemudian dikaitkan dan di kencangkan dengan peniti.

5. Langkah terakhir menggunakan anting-anting pada daun telinga bawah dengan cara membuka kaitannya dan menggunakan kalung yang dilingkarkan di leher dan diikat simpul di bagian belakang leher.

Berikut adalah tata busana komplit pada penari putri dalam pertunjukan tari Lenggang Pari. 


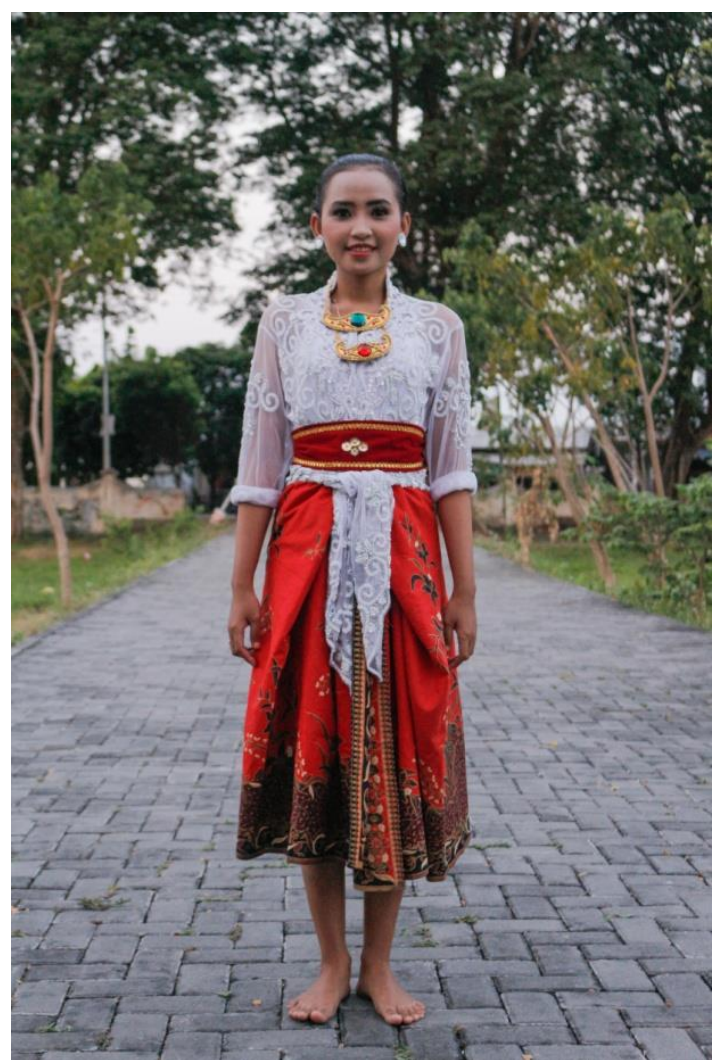

Foto 4.31 Tata Busana Penari Putri Tari Lenggang Pari (Sumber: Devvi Lutfiana, 19 Mei 2017)

Busana untuk penari putra menggunakan baju lengan panjang, celana panji (panjangnya sebatas lutut), kain jarik, stagen merah, sabuk, binggel (gelang kaki), gelang kain. Dapat dijelaskan bagian-bagian busana penari putra yang digunakan dalam pertunjukan tari Lenggang Pari sebagai berikut:

\section{Baju lengan panjang}

Baju lengan panjang merupakan baju dengan panjang lengan seukuran pergelangan tangan. Baju lengan panjang yang digunakan penari putra dalam pertunjukan tari Lenggang Pari berwarna merah, bentuk baju jadi tidak memiliki kancing sama sekali, pada tepi pergelangan tangan terdapat pita emas yang melingkari bagian pergelangan tangan, pada bagian leher terdapat motif putih seperti kace. 


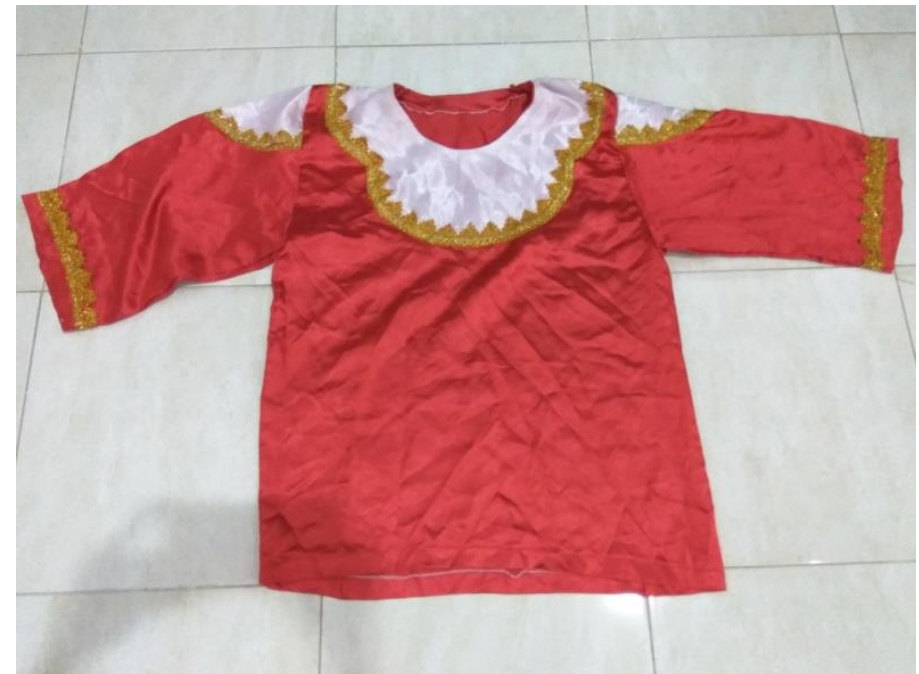

Foto 4.32 Baju Lengan Panjang Penari Putra Tari Lenggang Pari (Sumber: Devvi Lutfiana, 18 Mei 2017)

\section{Celana Panji}

Celana panji yaitu celana dengan panjang sebatas lutut. Celana panji yang digunakan penari putra dalam pertunjukan tari Lenggang Pari berwarna merah, mempunyai hiasan pada ujung celana berupa pita berwarna emas yang melingkar.

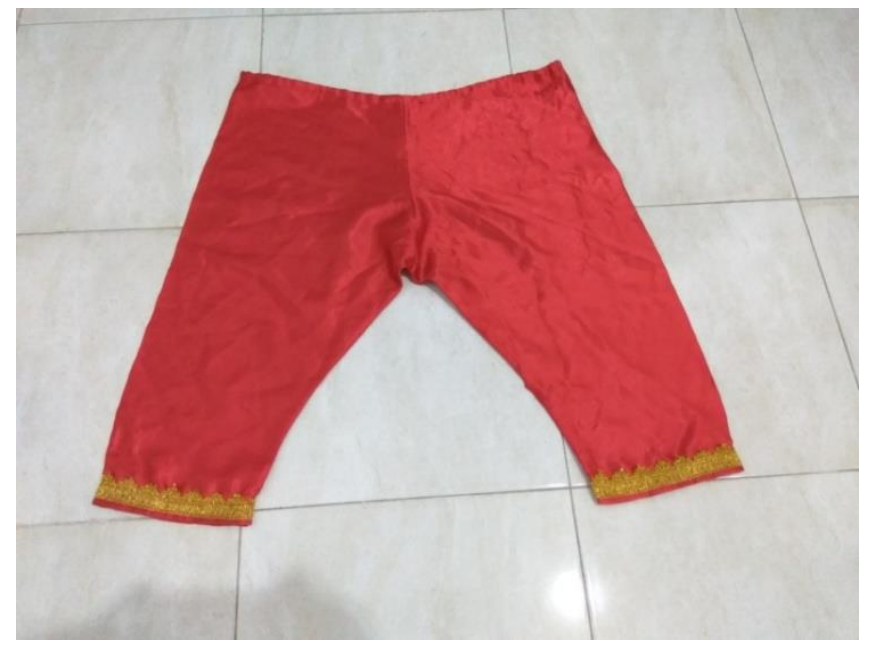

Foto 4.33 Celana Panji Penari Putra Tari Lenggang Pari (Sumber: Devvi Lutfiana, 18 Mei 2017) 


\section{Kain Jarik}

Kain jarik berbentuk lembaran persegi panjang yang panjang sehingga cukup untuk menutup dan melingkari dari perut sampai bagian diatas lutut pada penari putra. Bahannya terbuat dari kain dengan warna dasar putih dan mempunyai motif bunga merambat. Cara penggunaan kain jarik pada penari putra yaitu lebar kain dilipat menjadi dua, kemudian dililitkan di badan dan kedua ujungnya disatukan di depan perut dan dilipat-lipat di tengah-tengah antara dua kaki, kemudian stagen dililitkan ke pinggang agar lebih kuat.

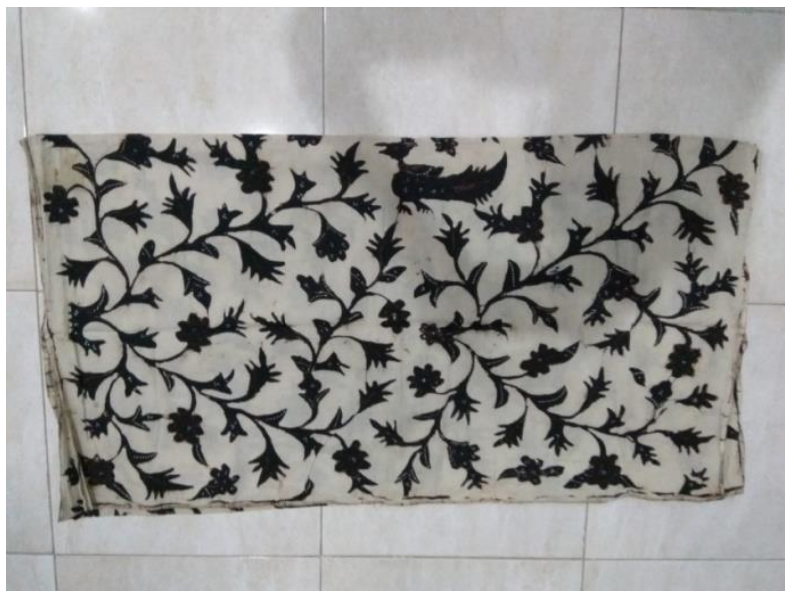

Foto 4.34 Kain Jarik Penari Putra Tari Lenggang Pari (Sumber: Devvi Lutfiana, 18 Mei 2017

\section{Stagen}

Stagen adalah ikat pinggang tradisional masyarakat Jawa. Ikat pinggang ini berupa tenunan kain, lebarnya sekitar 25 sentimeter dan panjangnya 2 meter. Ikat pinggang ini berfungsi untuk mengencangkan kain yang digunakan. Cara penggunaannya dililitkan sesudah penggunaan kain jarik, dalam pertunjukan tari Lenggang Pari stagen yang digunakan penari putra berwarna merah. 


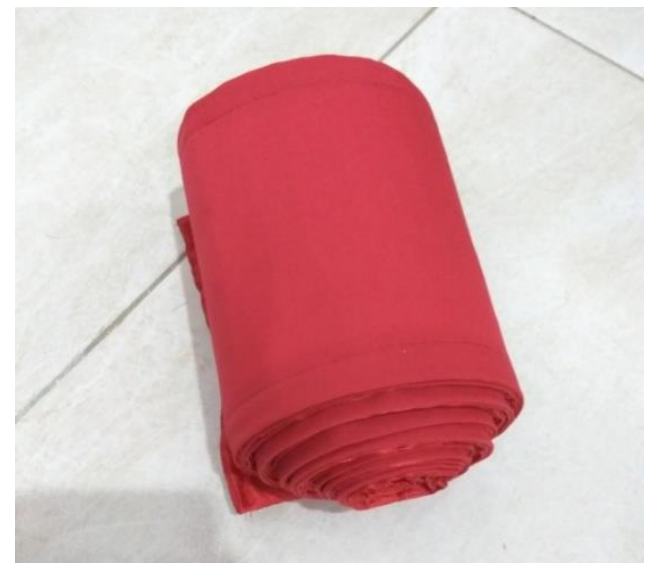

Foto 4.35 Stagen Penari Putra Tari Lenggang Pari

(Sumber: Devvi Lutfiana, 18 Mei 2017)

\section{Sabuk}

Sabuk berbentuk seperti ikat pinggang namun agak lebar. Bahannya terbuat dari kain berwarna merah dengan garis tengah kuning emas. Fungsinya sebagai pemanis setelah penggunaan stagen. Cara penggunaannya di lingkarkan dipinggang dengan menggunakan peniti atau jarum pentul.

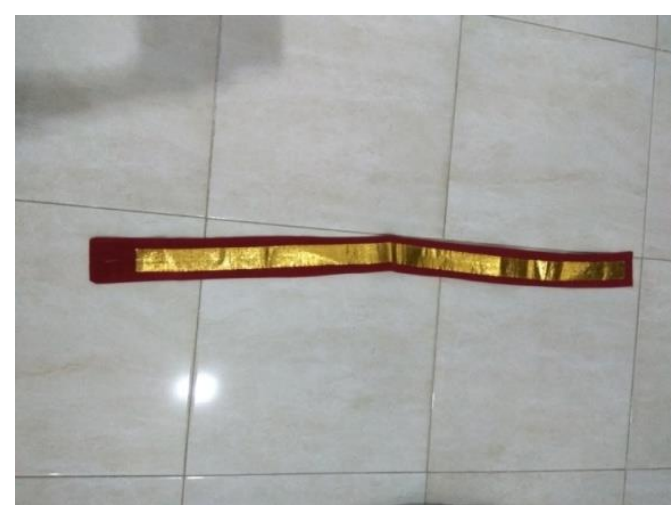

Foto 4.36 Sabuk Penari Putra Tari Lenggang Pari (Sumber: Devvi Lutfiana, 18 Mei 2017)

\section{Binggel (gelang kaki)}

Binggel (gelang kaki) merupakan sebuah perhiasan atau aksesoris melingkar yang diselipkan atau dikaitkan pada pergelangan kaki. 


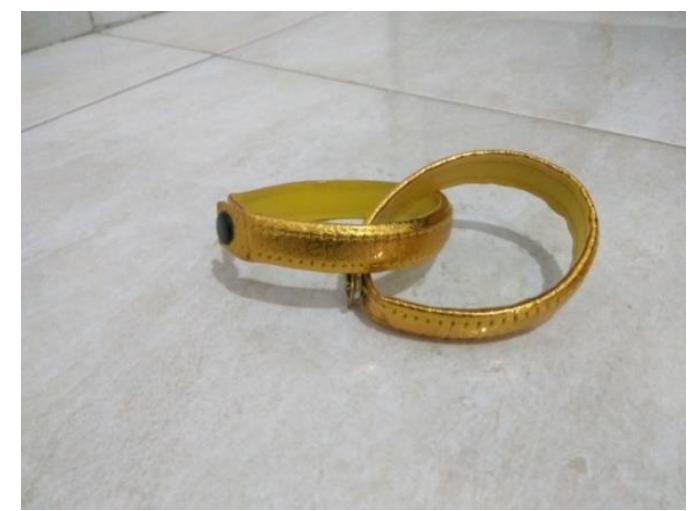

Foto 4.37 Binggel Putra Tari Lenggang Pari

(Sumber: Devvi Lutfiana, 18 Mei 2017)

\section{Gelang kain}

Gelang kain penari putra dalam pementasan tari Lenggang Pari merupakan sebuah aksesoris yang dibuat dari kain bludru berwarna merah dan diberi pita emas ditengah-tengahnya serta perekat pada bagian ujung. Fungsinya sebagai aksesoris pendukung saat pertunjukan tari Lenggang Pari. Cara penggunaannya dengan dililitkan pada pergelangan tangan dan mengaitkan kedua perekat yang terletak diujung.

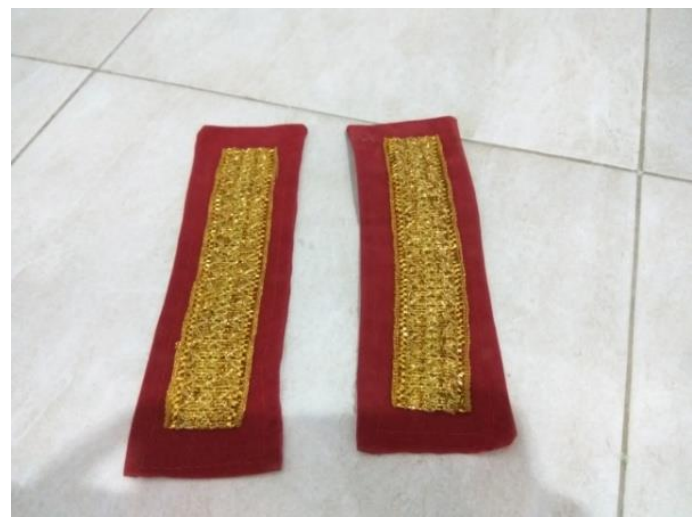

Foto 4.38 Gelang Kain Putra Tari Lenggang Pari

(Sumber: Devvi Lutfiana, 18 Mei 2017)

Adapun tata cara pemakaian busana penari putra dalam pertunjukan tari Lenggang Pari sebagai berikut: 
1. Memakai celana panji (panjangnya sebatas lutut), kemudian menggunakan baju lengan panjang yang dimasukan ke dalam celana dan dirapikan.

2. Memakai kain jarik yaitu lebar kain dilipat menjadi dua, kemudian dililitkan di badan dari perut sampe panjangnya kurang lebih diatas lutut dan kedua ujungnya disatukan di depan perut dan dilipat-lipat di tengah-tengah antara dua kaki

3. Stagen dililitkan ke pinggang agar lebih kuat, kemudian menggunakan sabuk yang dililitkan setelah penggunaan stagen dan dikaitkan dengan peniti.

4. Langkah terakhir mengenakan binggel pada kedua pergelangan kaki dan gelang kain pada kedua pergelangan tangan.

Berikut adalah tata busana komplit pada penari putra dalam pertunjukan tari Lenggang Pari.

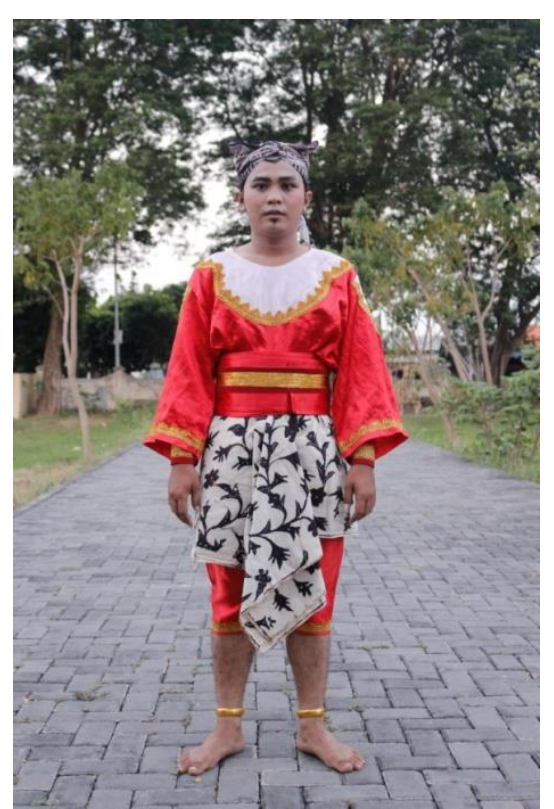

Foto 4.39 Tata Busana Penari Putra Tari Lenggang Pari (Sumber: Devvi Lutfiana, 19 Mei 2017)

Nilai keindahan tata busana dalam pertunjukan Tari Lenggang Pari dilihat dari kesatuan utuh penggunaan busana yang digunakan. Warna-warna dasar 
busana dalam seni pertunjukan mempunyai makna simbolis yang dapat mengarahkan pemahaman karakteristik atau figur tokoh. Warna merah dan putih sebagai warna dominan yang mendukung tatanan busana pada tari Lenggang Pari mempunyai keunikan tersendiri. Keunikan tersebut terletak pada pemaknaan warna sebagai simbol kehidupan dalam tari Lenggang Pari. Warna merah biasanya memberikan kesan berani, agresif dan dinamis akan tetapi dalam tari Lenggang Pari warna merah menjadi perlambangan benih Ibu yang membutuhkan pasangan untuk menyempurnakan suatu simbol kesuburan. Sedangkan warna putih biasanya merupakan warna yang memiliki kesan suci, setia dan aksentusi yang berhubungan dengan nirwana, akan tetapi dalam tari Lenggang Pari warna putih dimaknai sebagai warna yang melambangkan benih Bapak.

Korelasi warna busana diwujudkan dalam gerak-gerak tari dengan berpasangan. Konsep laki-laki dan perempuan dalam tari Lenggang Pari dikaitkan dengan perlambangan kesuburan dan dituangkan pula dalam pemaknaan warna busana nya melalui perwujudan motif gerak tari Lenggang Pari. Busana diken akan sesuai dengan konsep kerakyatan, sederhana tidak memiliki ornamen yang banyak. Kebaya dengan payet membuatnya terkesan glamor sehingga diimbangi dengan penggunaan kain jarik yang sangat sederhana. Baju yang dikenakan penari putra mencitrakan rakyat sederhana. Warna kuning emas yang muncul pada busana tari Lenggang Pari dimaknai sebagai rasa kebikjasanaan seorang petani. Keragaman bentuk dan warna-warna busana dalam pertunjukan tari Lenggang Pari sebagai sarana dan media presentasi estetis. 


\subsubsection{Iringan/musik}

Iringan atau musik pada pertunjukan tari Lenggang Pari berfungsi untuk mempertegas irama tari, pemberi suasana atau ilustrasi, mempertegas ekspresi gerak dan merangsang penari. Musik sebagai pengiring tari juga membantu mengingatkan penari ketika penari tiba-tiba lupa dengan gerakannya, dengan musik penari dapat melahirkan gerakan improvisasi. Instrumen yang digunakan dalam pembuatan musik tari Lenggang pari yaitu instrumen tradisi dan instrumen barat. Instrumen tradisinya ada saron, demung, peking, bonang barung, bonang penerus, kendang (jaipong), gong. Instrumen barat gitar, bass, menggunakan recorder dengan suling pada ilustrasi awal. Berdasarkan hasil wawancara Bapak Nugroho tanggal 18 April 2017 sebagai berikut:

“.....Konsep musik pada tari Lenggang Pari penggabungan antara unsur tradisi dan unsur musik barat. Pembuatan iringan pada tari Lenggang pari bermula pada konsep garapan tariannya. Untuk masalah temanya dari bu yanti menyerahkan sepenuhnya ke saya tentang alur musiknya bagaimana itu terserah saya. Biasanya musik mengikuti tari tetapi kali ini tari mengikuti musik, dalam penggarapannya bu yanti juga langsung terjun langsung untuk mengeksploasi gerak dangan musik. Laras yang digunakan laras slendro, slendronya menggunakan slendro sanga pada gendhing lancaran Lesung Jumengglung yang telah diaransemen. Dalam proses pembuatannya cukup minimalis ada 8 orang. Pembuatannya lipsing semua memainkan alat musik dengan ditumpuk. Ada beberapa alur karna mengacu pada konsep tari jadi musik mengikuti konsep tarinya, misalnya gerakan ilustrasi jadi saya membuat musik ilustrasi. Ada juga tembang tegalan dalam tari Lenggang Pari yang dinyanyikan sendiri oleh bapak saya. Musik sebagai pengiring tari berfungsi mendukung tari supaya lebih menarik. Ketika orang melihat pertunjukan tari Lenggang Pari diharapkan akan kembali sadar bahwa padi itu sangat penting bagi kehidupan. Orang lebih menghargai petani dengan mensyukuri apa yang dimakan hari ini”". 
Notasi musik tari Lenggang Pari

1. Prolog( musik suasana)

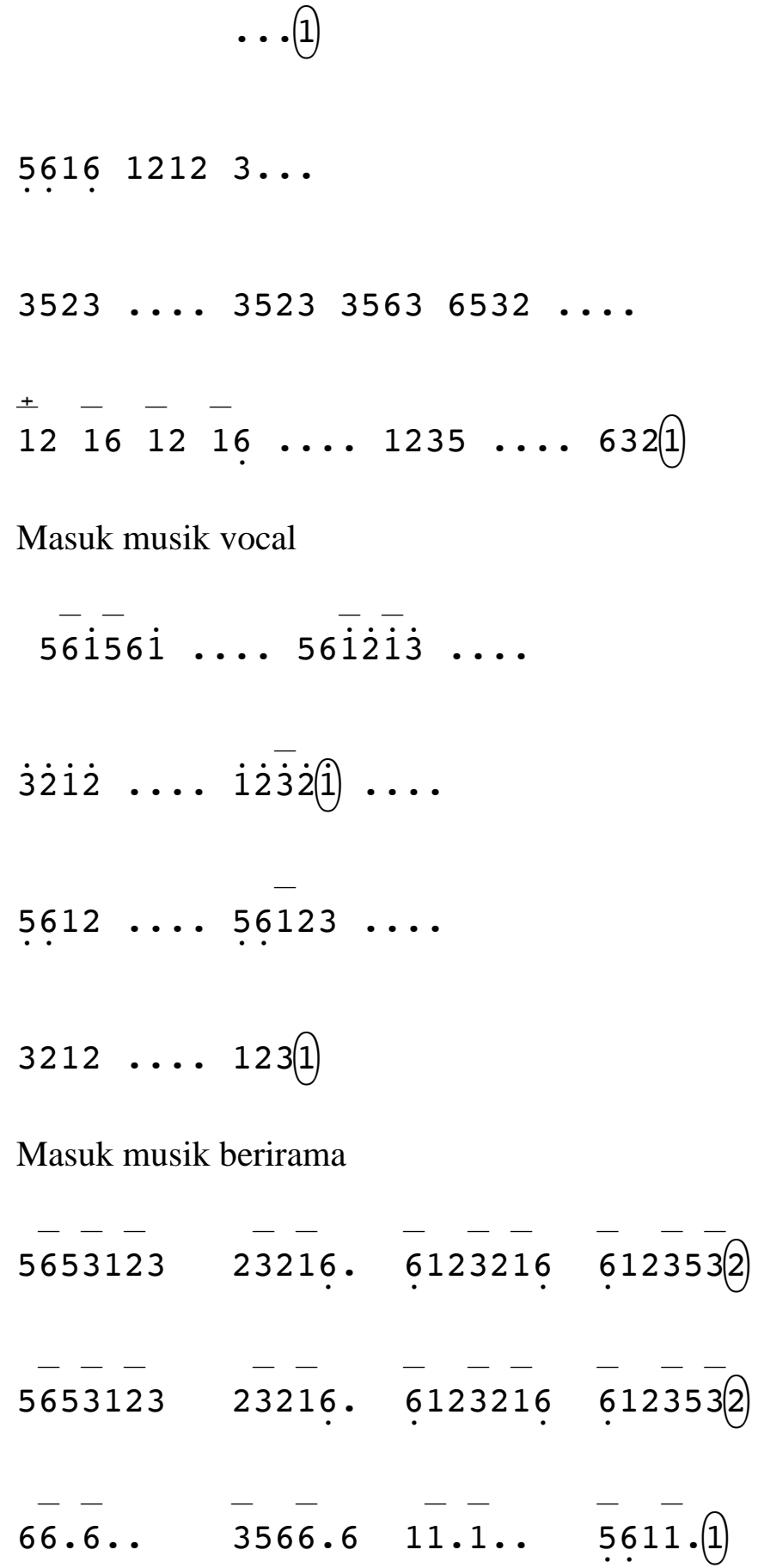


$\begin{array}{cccc}\overline{6} . \overline{6} . . & \overline{3} 56 \overline{6} .6 & \overline{1} \cdot \overline{1} . . & \overline{5} 61 \overline{1} .1\end{array}$

$\begin{array}{cccc}\overline{1} \cdot \overline{11} \cdot & \overline{1} \cdot \overline{11} \cdot \overline{11} \cdot 11 . & 1116\end{array}$

Masuk musik konflik

-_6666 $666 \mathrm{~g} 6 \quad 1111 \quad 111 \mathrm{~g} 6$

$\begin{array}{lll}\mathrm{XX}<6 . \mathrm{b} 5.3 & .213 \quad 2 . \mathrm{b} 1.96\end{array}$

2. Masuk tembang suluk tegalan

$\begin{array}{llllllllllll}2 & 5 & 6 & 6 & 6 & 6 & 2 & ! & 6 & 3 & 2 & 2\end{array}$

La-mun si- ra mban- ting ra- ga ba- da- ni- ra

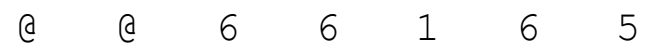

Ce- gah da- har lan gu- ling

$\begin{array}{llllll}3 & 3 & 2 & 3 & 5 & 5\end{array}$

$\mathrm{Ku}-\mathrm{du}$ bi- sa nyu- da

$\begin{array}{lllllll}3 & 3 & 2 & 3 & 5 & 5 & 5\end{array}$

Nep- su sing ngam- bra- am- bra

$\begin{array}{lllllll}3 & 3 & 5 & 3 & 2 & 2 & 2\end{array}$

Sa- kar- san ing si- re- ki

$\begin{array}{llllllllllll}5 & 3 & 2 & 2 & 2 & 2 & 5 & 2 & 6 & 2 & 3 & 5\end{array}$

Mu- ga ka- tam- pa sa- kar- sa- ning du- ma- di

3. Masuk gendhing lanc. Lesung Jumengglung SL

\begin{tabular}{llll} 
& & \multicolumn{1}{c}{ BPg5 } \\
-2525 & $653 g 2$ & 3212 & $535 g 6$ \\
2626 & $161 g 5$ & 2126 & $216 g 5+$
\end{tabular}

Ompak:

\begin{tabular}{|c|c|c|}
\hline.$b 56 b 23 b 5$. & $5 \mathrm{~b} ! 6 \mathrm{~b} 53 \mathrm{~b} 1 \mathrm{~g} 2$ & . b2 3by1b2 . \\
\hline $\mathrm{b} 226 \mathrm{~b} 226$ & b1.b16b1.b1g5 b5 ... & $\mathrm{b} 55 \ldots$ \\
\hline b55 . . & b55... $216 \mathrm{~g} 5$ & \\
\hline
\end{tabular}


Notasi vokal

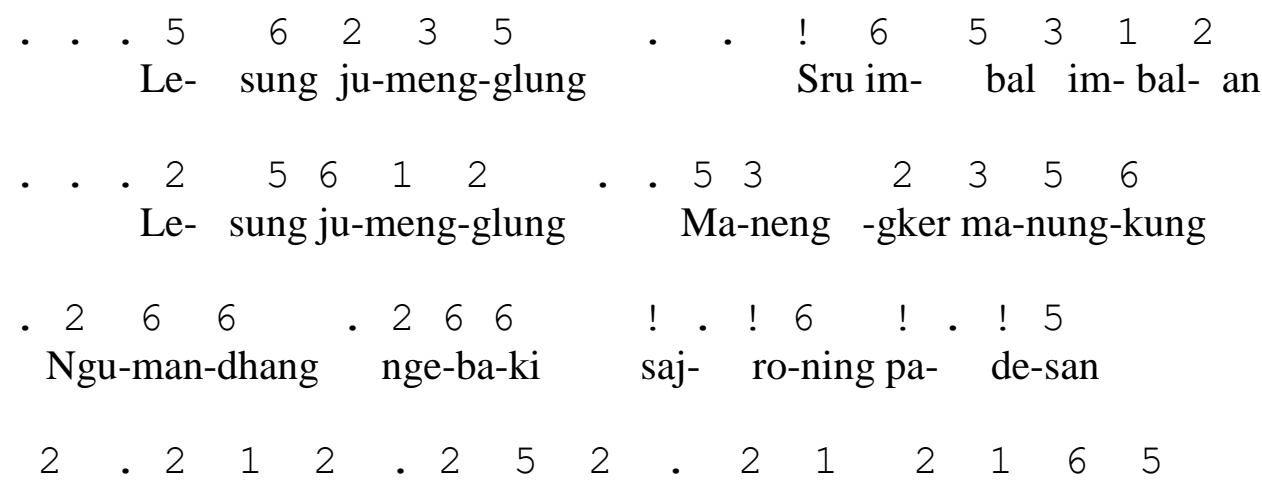

Thok thok thek thok thok dhung thok thok thek thok thek thok dhung

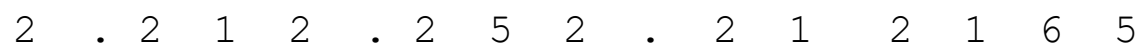
Thok thok thek thok thok dhung thok thok thek thok thek thok dhung

4. Masuk musik endhing

2b12b5b21b25 .555 2b12b5b21b25 . .55g5

Keindahan iringan tari Lenggang Pari tampak pada keselarasan antara musik dengan gerak tari. Nilai keindahan iringan pada pertunjukan tari Lenggang Pari dapat dilihat dari garap musiknya. Jenis Instrumen yang digunakan mampu menghasilkan musik dengan ilustrasi suasana riang, sangat riang, tegang, bersemangat. Didukung dengan vokal dan senggakan-senggakan khas dari penata musik memberikan kehidupan pada iringan tari tersebut. Pembagian alur yang sangat nampak dengan permainan tempo musik, permainan melodi, irama dan tembang suluk tegalan mampu memberi kesan emosional yang mendalam. Gendhing lancaran lesung jumengglung slendro sanga yang digunakan memberi ilustrasi sebagai penggambaran kehidupan petani. Fungsi gending ini membentuk suasana-suasana yang menghantarkan penari berekspresi. 
Keindahan iringan tari Lenggang Pari juga dapat dilihat dari pemilihan dan pemaknaan penggunaan tembang suluk tegalan serta gending lancaran lesung jumengglung slendro sanga. Berdasarkan hasil wawancara Bapak Slamet Waluyo tanggal 30 Juli 2017 pemaknaan tersebut dapat dijelaskan sebagai berikut:

“...Tembang suluk tegalan mempunyai arti berserah diri kepada gusti Allah. Ketika badan kita raga kita jiwa kita melakukan puasa, pertapaan, ibadah, tafakur dan segala kegiatan untuk mensucikan diri dianjurkan untuk menjauhi semua yang merupakan godaan seperti makan. Harus bisa menahan nafsu dan menahan segala godaan. Selebihnya badan kita raga kita dan jiwa kita hanya bisa berharap bersih, suci dengan berserah diri kepada gusti Allah supaya mengabulkan permintaannya. Dalam tari Lenggang Pari diibaratkan sebagai seorang petani harus mempunyai rasa ikhlas, semangat juang yang tinggi agar kehidupan tetap berlangsung dengan hasil padi yang dipanen nantinya. Kegiatan nandur, mupuk, mengalirkan air ke ladang persawahan merupakan bentuk-bentuk usaha petani agar menghasilkan padi yang nantinya diolah menjadi beras sebagai bahan pangan. Gendhing lancaran lesung jumengglung slendro sanga menggambarkan kegiatan menumbuk padi yang dilakukan petani setelah panen. menumbuk padi dahulu kala menggunakan lesung bukan mesin-mesin penggiling yang ada di resmil. Menggunakan lesung yang terbuat dari kayu dengan panjang 1-2 meter sehingga kuat. Alu berfungsi sebagai penumbuk pada lesung yang menjadi tempat tumbukan. Alu dan lesung menjadi penggambaran kehidupan laki-laki dan wanita, menceritakan kesuburan yang menghasilkan generasi untuk tetap meneruskan kehidupan. Padi yang ditumbuk menjadi beras yang kemudian akan dimasak sehingga menghasilkan nasi yang dapat dikonsumsi untuk mempertahankan kehidupan. Gending lancaran lesung jumengglung slendro sanga menceritakan kerja keras untuk membuat padi yang sudah dipanen menjadi bersih agar menjadi beras dan dapat dikonsumsi. Petani memilas padi dengan menggunakan alat tradisional seperti lesung. Setelah selesai kotekan dengan menggunakan lesung. Setiap tumbukan alu pada lesung akan menghasilkan nada-nada tersendiri yang menciptakan rasa bergairah, semangat juang dan keceriaan dalam panen raya".

\subsubsection{Setting Panggung}

Pertunjukan merupakan suatu kegiatan yang didalamnya terdapat suatu

sajian yang dipertontonkan kepada seseorang bahkan masyarakat secara luas.

Sebuah pertunjukan tari tidak terlepas dari sebuah tempat pementasan. Panggung 
merupakan tempat atau lokasi yang digunakan untuk menyajikan suatu tarian. Pada pertunjukan tari Lenggang Pari bisa dilakukan di tempat terbuka dan tertutup. Pertunjukan tari Lenggang Pari lebih sering dilakukan di panggung tertutup dengan jenis panggung tabang atau panggung keliling yang diletakan di halaman terbuka maupun pendapa. Seperti pada penelitian, pertunjukan tari Lenggang Pari dilakukan dengan menggunakan panggung jenis tabang atau panggung keliling yang penempatannya di halaman terbuka tepatnya di tengah persawahan di Desa Ketanggungan Brebes.

Panggung dalam pertunjukan tari Lenggang Pari dalam acara Panen Raya Nasional Padi MSP yang dilakukan di Desa Ketanggungan Brebes mempunyai bentuk panggung tapal kuda yang dapat disaksikan penonton dari sisi depan dan samping kiri dan kanan. Panggung tapal kuda tersebut ditata sedemikian rupa sesuai dengan konsep pada acara tersebut. Berikut ini adalah bentuk panggung dan tata pentas dalam pertunjukan tari Lenggang Pari pada saat penelitian dilakukan.

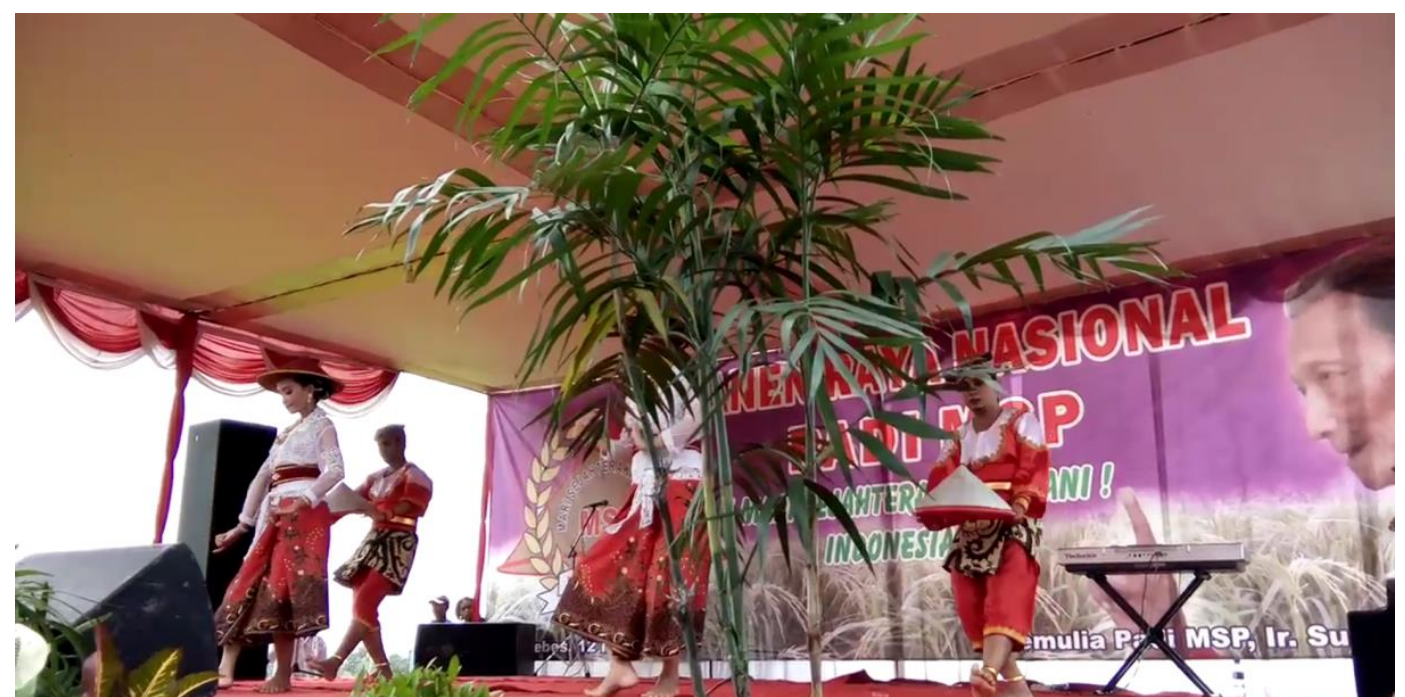


Foto 4.40 Panggung Pertunjukan Tari Lenggang Pari

(Sumber: Devvi Lutfiana, 12 Maret 2017)

Nilai keindahan panggung dengan setting terwujud dalam penataan panggung yang memiliki kualitas pertunjukan yang layak, memadahi dan menarik diwujudkan dalam bentuk penataan panggung yang mempertimbangkan dari segi artistik setting. Setting panggung dalam pertunjukan tari Lenggang Pari pada saat penelitian dilakukan menunjukan kesederhanaan bahkan menggunakan dengan memanfaatkan setting alami seperti suasana persawahan. Penataan dekorasi dan ornamen panggung tidak berlebihan sehingga ruang gerak penari tidak terganggu dan menampilkan kualitas penari secara maksimal yang memberikan kekuatan ekspresi pertunjukan. Penataan soundsystem juga menyeluruh pada sisi-sisi panggung sehingga iringan tari mampu didengarkan oleh penari dengan baik.

\subsubsection{Properti}

Properti merupakan suatu bentuk peralatan penunjang gerak sebagai wujud ekspresi dalam pertunjukan tari Lenggang Pari yang mempunyai daya tarik tersendiri untuk memikat penonton. Properti yang digunakan dalam pertunjukan tari Lenggang Pari berupa caping dengan warna merah emas dan putih emas. 
Penggunaan caping sebagai properti pada pertunjukan tari Lenggang Pari sesuai dengan konsep tarian yaitu menggambarkan kehidupan petani. Caping sangat erat kaitannya dengan petani.

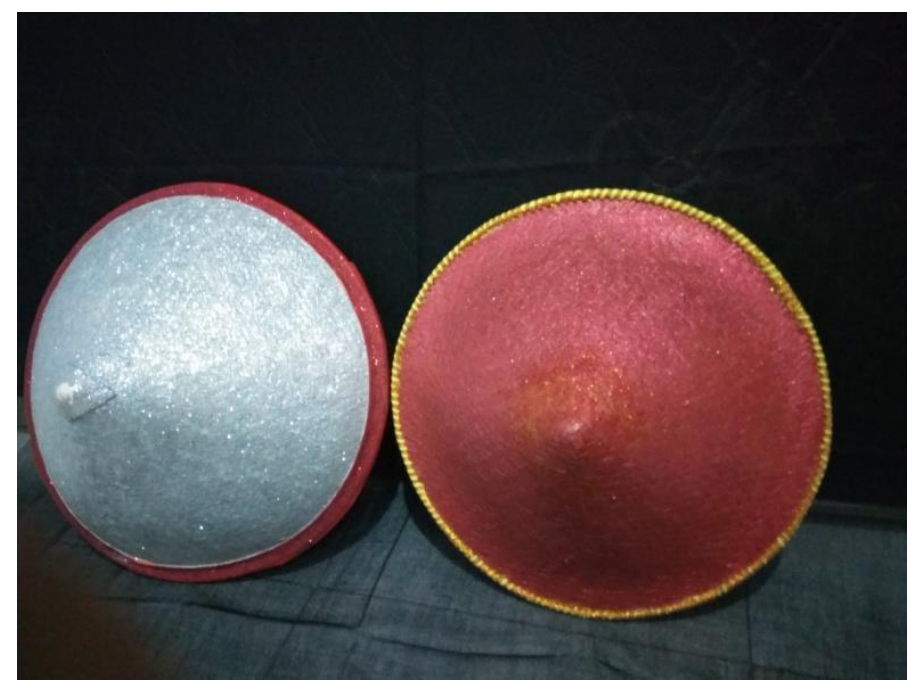

Foto 4.41 Caping Tari Lenggang Pari

(Sumber: Devvi Lutfiana, 18 Mei 2017)

Nilai keindahan properti dalam pertunjukan tari Lenggang Pari difungsikan sebagai pelengkap sajian tari. Penggunaan properti caping oleh penari mampu memvisualkan karakter seorang penari dan penggambaran kehidupan petani dalam pertunjukan tari Lenggang Pari. Penggambaran petani diwujudkan melalui properti caping yang digunakan sebagai identitas diri seorang petani dengan pola dan motif gerak penari dengan properti. Caping yang digunakan sebagai properti saat menari menimbulkan tenaga yang digunakan dalam ragam gerak tertentu terlihat jelas sehingga mampu memperlihatkan nilai keindahan tari melalui properti caping yang digunakan. Caping sebagai properti tari juga difungsikan sebagai perwujudan simbol-simbol sehingga penonton mampu memahami dan menangkap isi dan penampilan tari.

\subsubsection{Tata Lampu dan Tata Suara}


Pertunjukan tari Lenggang Pari bisa dilakukan di luar ruangan dan di dalam ruangan atau gedung. Pertunjukan tari Lenggang Pari biasanya diadakan tidak hanya siang hari namun juga pada malam hari. Penggunaan tata lampu dan tata suara dalam pertunjukan tari Lenggang Pari disesuaikan dengan tempat dan waktu pentas juga dengan acara yang diselenggarakan.

Pada saat penelitian yang dilakukan oleh peneliti, pertunjukan tari Lenggang Pari pada saat itu berada di luar ruangan atau area terbuka dengan didukung panggung sebagai tempat pementasan dan diadakan pada siang hari. Pertunjukan tari Lenggang Pari pada siang hari menggunakan sinar alami yaitu sinar matahari sebagai penerangan pementasan. Penerangan pada pertunjukan tari Lenggang Pari dengan cahaya alami dari sinar matahari pada saat peneliti melakukan penelitian memberi kesan sederhana. Kemudian tata suara dalam panggung pementasan ada lima buah sound besar di bagian depan panggung, samping panggung dan sudut belakang panggung di sisi kanan dan kiri.

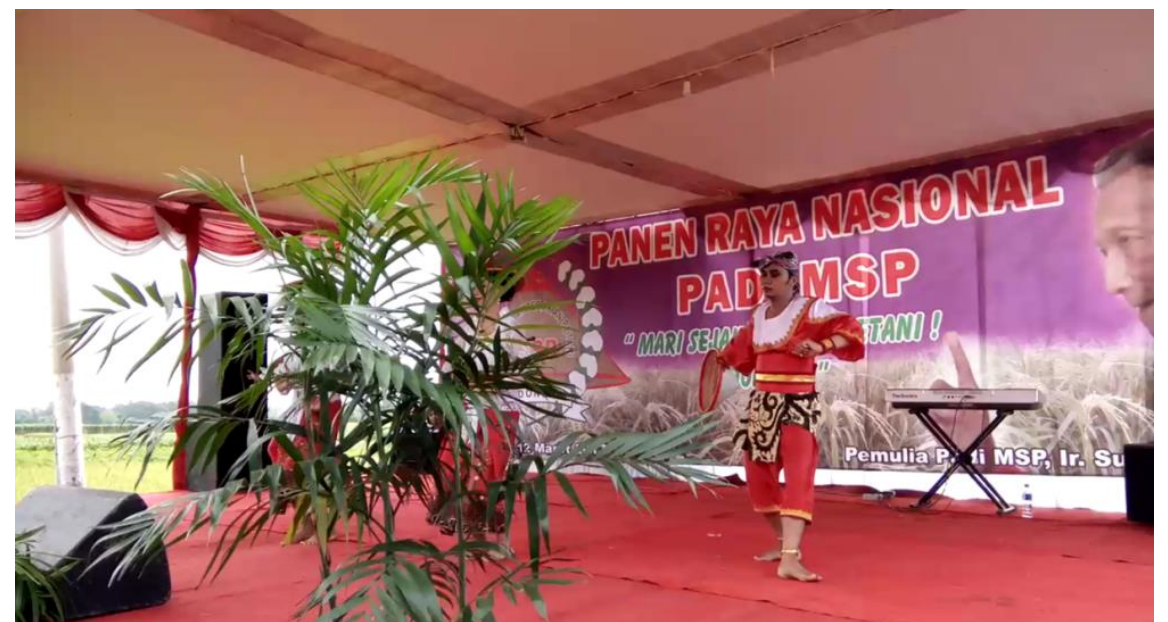




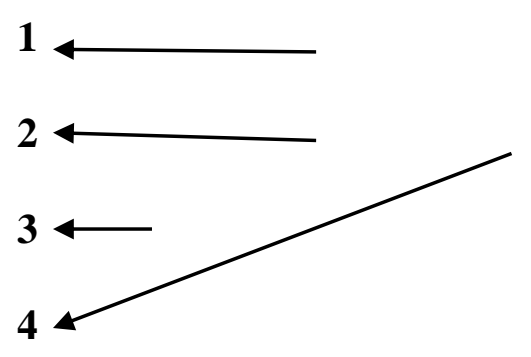

$>5$

Foto 4.42 Tata Lampu dan Tata Suara Tari Lenggang Pari

(Sumber: Devvi Lutfiana, 12 Maret 2017)

\section{BAB V}

\section{PENUTUP}

\subsection{Simpulan}

Berdasarkan hasil penelitian tari Lenggang Pari adalah tarian kreasi baru yang diciptakan pada akhir bulan November tahun 2015 oleh Ibu Sri Damayanti. 
Tari Lenggang Pari merupakan komposisi tari berpasangan putra dan putri. Tari berpasangan ini merupakan bentuk tari kerakyatan yang disajikan untuk menghibur penonton. Tari Lenggang Pari menggambarkan aktifitas bercocok tanam. Tari Lenggang Pari ditarikan oleh penari putra dan putri sebagai wujud dari lambang kesuburan yang berkaitan erat dengan kemakmuran masyarakat. Konsep mengenai putra dan putri yang digunakan adalah konsep dwi karsa yang memiliki arti kesatuan dua unsur kehendak dalam suatu kehidupan.

Estetika merupakan cerapan indra kemudian penikmat melakukan persepsi atas tarian tersebut. Keindahan suatu benda seni dapat berbeda antara satu orang dengan yang lain, maka pada karya tulis Estetika Bentuk Pertunjukan Tari Lenggang Pari di Sanggar Seni Perwitasari Kelurahan Kemandungan Kecamatan Tegal Barat Kota Tegal dapat dilihat dari pola pertunjukan dan elemen pertunjukan tari Lenggang Pari. Bentuk pertunjukan tari Lenggang Pari memiliki tiga pola pertunjukan yaitu bagian awal, bagian inti atau isi dan bagian akhir serta elemen yang mendukung pertunjukan tari Lenggang Pari yaitu tema, alur cerita/alur dramatik, gerak, penari, ekspresi wajah, Tata rias dan busana, iringan/musik, setting panggung, properti, tata lampu dan tata suara.

Keindahan bentuk pertunjukan tari Lenggang Pari nampak pada gerak yang dilakukan penari putra dan putri dengan intensitas tempo yang cepat dan lambat, aksen dan kualitas gerak sesuai dengan urutan ragam gerak yang diiringi musik tari Lenggang Pari yang berkesinambungan memunculkan kesan lincah dan dinamis. Kesan lincah timbul saat tempo yang digunakan cepat. Kesan dinamis timbul pada saat iringan sesuai dengan ketukan gerak dan iringan yang dimainkan 
memberikan aksen-aksen pada gerak. Pengulangan ragam gerak lumaksono ngracik, penghubung dan ngasoh ditonjolkan untuk dapat menegaskan keunikan dari bentuk tari Lenggang Pari. Arah pergerakan penari putra dan putri dengan variasi gerak maju dan mundur, ke depan dan ke belakang, ke kanan dan kiri dilakukan secara simetris. Kesimetrisan ini menimbulkan citra kuat karena desain ruangnya seimbang.

Tema dan alur cerita yang dihasilkan dari cerita kehidupan masyarakat dengan menggambarkan aktifitas kehidupan petani menggambarkan nilai kehidupan yang teladan, bekerja keras, kebersamaan dan rasa syukur. Penggunaan tata rias wajah dan busana memberikan kesan tersendiri pada pertunjukan tari Lenggang Pari. Warna busana yang didominasi warna merah dan putih melambangkan bentuk kesucian dan kesuburan dalam kehidupan. Selain itu, penggunaan tata lampu, tata suara, properti dengan setting panggung yang terlihat sederhana dengan dekorasi seadanya menunjang penampilan pertunjukan tari Lenggang Pari.

\subsection{Saran}

Saran yang ingin disampaikan oleh penulis berdasarkan hasil penelitian yaitu dapat dikemukakan saran-saran sebagai berikut:

\subsubsection{Bagi Pelaku Pertunjukan Tari Lenggang Pari}

Penari tari Lenggang Pari diharapkan akan terus berlatih dengan rutin lagi mengenai teknik dasar gerak tari untuk meningkatkan kualitas gerak saat menari. 
Penari tari Lenggang Pari diharapkan dapat menguasai tari Lenggang Pari untuk dikemudian hari digunakan untuk kegiatan yang baik misalnya dapat di tampilkan di suatu acara atau diajarkan kembali pada generasi selanjutnya.

\subsubsection{Bagi Sanggar Seni Perwitasari Kelurahan Kemandungan Kecamatan Tegal Barat Kota Tegal}

Sanggar Seni Perwitasari sebagai salah satu sanggar yang berada di Kota Tegal diharapkan dapat terus mengembangkan karya seni dengan melestarikan potensi kesenian daerah yang ada didalamnya. Dalam kegiatan yang telah dijalankan agar tetap dijaga kelestariannya untuk lebih menarik lagi agar memunculkan bibit-bibit generasi penerus selanjutnya untuk mengikuti latihan menari.

\section{DAFTAR PUSTAKA}

Arikunto, Suharsimi. 2010. Prosedural Penelitian Suatu Pendekatan Praktik. Jakarta: PT. Rineka Cipta.

Arimbi, Agiyan Wiji Pritaria. 2016. Kajian Nilai Estetis Tari Megat-Megot Di Kabupaten Cilacap. Jurnal seni tari Vol.5 No.1. Semarang: FBS UNNES

Azwar, Saifuddin. 2013. Metode Penelitian. Yogyakarta: Pustaka Pelajar.

Bahari, Nooryan. 2008. Kritik Seni: Wacana, Apresiasi, dan Kreasi. Yogyakarta: Pustaka Pelajar. 
Bastomi, Suwaji. 1998. Wawasan Seni. Semarang: IKIP Press.

Cahyono, Agus. 2006. Seni Pertunjukan Arak-arakan dalam Upacara Tradisional Dugderan di Kota Semarang. Jurnal Harmonia Vol III No. 3 Unnes.

Djelantik, AAM. 1999. Estetika Sebuah Pengantar, Masyarakat Seni Pertunjukan Indonesia, Bandung.

Endraswara, Suwandi. 2012. Metodologi Penelitian Kebudayaan. Yogyakarta: Gajah Mada University Press.

Hadi, S. 1996. Aspek-Aspek Koreografi Kelompok. Yogyakarta: Manthili Yogyakarta.

Herimanto dan Winarno. 2010. Ilmu Sosial dan Budaya Dasar. Jakarta: Bumi Aksara.

Jazuli, M. 2008. Paradigma Kontekstual Pendidikan Seni. Semarang: Unesa University Press.

Komariyah, Istiqomah. 2016. Nilai Estetika Barongan Wahyu Arom Joyo Di Desa Gunungsari Kecamatan Tlogowangu Kabupaten Pati. Jurnal seni tari Vol.5 No.2. Semarang: FBS UNNES.

Kusmayati, A.M Hermin. 2000. Arak-arakan Seni Pertunjukan dalam Upacara Tradisional di Madura. Yogyakarta: Tarawang Press

Langer, Suzanne K. 1956. Problem of Arts. terj. FX Widaryanto. 2006. Problematika Seni. Bandung: Sunan Ambu Press.

Lestari, Wahyu. 1993. Teknoligi Rias Panggung. Semarang : FBS. UNNES.

Made astini, Siluh dan Usrek tani utina. 2007. Tari Pendet Sebagai Tari Balihbalihan (kajian koreografi) Harmonia jurnal pengetahuan dan pemikiran seni Vol.VIII No.2. Semarang: FBS UNNES.

Maryono. 2011. Penelitian Kualitatif Seni Pertunjukan. Surakarta: ISI Press Solo. .2012. Analisa Tari. Surakarta: ISI Press Solo.

Moeloeng, Lexy J. 2007. Metode Penelitian Kualitatif. Bandung: PT Remaja Posdakarya.

Murgiyanto, Sal. 1983. Koreografi Pengetahuan dasar Komposisi Tari. Jakarta: Departemen Pendidikan dan kebudayaan.

2002. Kritik Tari Bekal Dan Kemampuan Dasar. Jakarta: Ford Foundation Dan Masyarakat Seni Pertunjukan Indonesia. 
Pebriyanti, Sestri Indah. 2013. Makna Simbolik Tari Bedhaya Tunggal Jiwa. Harmonia jurnal pengetahuan dan pemikiran seni Vol.13 No.2. Semarang: FBS UNNES.

Ratna, I Nyoman. 2007. Estetika Sastra dan Budaya. Yogyakarta: Pustaka Pelajar.

Rizanti, Elisa. 2016. Kajian Estetis Tari Rengga Manis Di Kabupaten Pekalongan. Jurnal seni tari Vol.5 No.1. Semarang: FBS UNNES.

Sarastiti, Dian dan veronica eni iryanti. 2012. Bentuk Penyajian Tari Ledhek Barangan Di Kabupaten Blora. Jurnal seni tari Vol.1 No.1. Semarang: FBS UNNES.

Sedyawati, edi dkk. 1986. Pengetahuan Elementar Tari Dan Beberapa Masalah Tari. Jakarta: Direktorat kesenian departemen pendidikan dan kebudayaan.

Shaidily, Hasan. 1993. Pokok-pokok Pembangunan Masyarakat Desa. Jakarta: PT. Rineka Cipta.

Soedarsono. 1999. Metodologi Penelitian Seni Pertunjukkan dan Seni Rupa. Yogyakarta: Masyarakat Seni Pertunjukkan Indonesia.

Soetarno; Sunardi dan Sudarsono. 2007. Estetika Pedalangan. Surakarta: ISI Surakarta.

Jazuli, M. (2011). MODEL PEMBELAJARAN TARI PENDIDIKAN PADA SISWA SD/MI SEMARANG. Harmonia: Journal of Arts Research and Education, 10(2). doi:https://doi.org/10.15294/harmonia.v10i2.59

Kusumadewi, L., \& Suharto, S. (2011). PENINGKATAN HASIL BELAJAR SENI MUSIK DENGAN MEDIA AUDIO VISUAL MELALUI METODE BERVARIASI. Harmonia: Journal of Arts Research and Education, 10(2). doi:https://doi.org/10.15294/harmonia.v10i2.63

Adi Sam, T. (2011). PERMAINAN ANAK YANG MENGGUNAKAN NYANYIAN (Kajian Wilayah: Jakarta, Depok, Bogor, Tangerang, dan Bekasi). Harmonia: Journal of Arts Research and Education, 10(2). doi:https://doi.org/10.15294/harmonia.v10i2.57

Suharto, S., Sumaryanto, T., Ganap, V., \& Santosa, S. (2016). Banyumasan Songs As Banyumas People s Character Reflection. Harmonia: Journal of Arts Research and Education, 16(1), 49-56. doi:https://doi.org/10.15294/harmonia.v16i1.6460

Suharto.(2016). Musikalitas dan Makna Simbolik Pertunjukan Calung Banyumasan di Kabupaten Banyumas. Research Report. Semarang: Lembaga Penelitian Unnes. 
Heriwati, S. (2011). METAFORA DALAM CAKEPAN TEMBANG TEMBANG JAWA. Harmonia: Journal of Arts Research and Education, 10(1). doi:https://doi.org/10.15294/harmonia.v10i1.49

PEMANFAATAN DAN PENGEMBANGAN LAGU ANAK-ANAK DALAM PEMBELAJARAN TEMATIK PADA PENDIDIKAN ANAK USIA DINI / TK

Budiarti, M. (2014). KONSEP KEPESINDENAN DAN ELEMEN-ELEMEN DASARNYA. Harmonia: Journal of Arts Research and Education, 13(2). doi:https://doi.org/10.15294/harmonia.v13i2.2781

Hidajat, R. (2014). The Popularity of Waranggana Tayub Malang through Body Exploitation. Harmonia: Journal of Arts Research and Education, 14(2), 72-77. doi:https://doi.org/10.15294/harmonia.v14i2.3288

Widodo, W. (2011). Nuansa Laras Diatonik dalam Macapat Semarangan (Diatonic Scale Atmosphere in Semarang Style Macapat).. Harmonia: Journal of Arts Research and Education, 7(1). doi:https://doi.org/10.15294/harmonia.v7i1.751

Suharto, S. (2011). Refleksi Teori Kritik Seni Holistik : sebuah Pendekatan Alternatif dalam Penelitian Kualitatif bagi Mahasiswa Seni (Reflection on Art Criticism and Holistic Art Criticism : an Alternative Approach of Qualitative Research for Art Students). Harmonia: Journal of Arts Research and Education, 8(1). doi:https://doi.org/10.15294/harmonia.v8i1.803

Sugiyono. 2008. Metode Penelitian Pendidikan. Bandung: Alfabeta.

.2009. Metode Penelitian Kuantitatif Kualitatif and R\&D. Bandung: Alfabeta.

Sumardjo, Jakob. 2000. Filsafat Seni. Bandung: Penerbit ITB. 2006. Estetika Paradoks. Bandung: Sunan Ambu Press.

Sumarsam. 2002. Hayatan Gamelan: Hayatan Lagu dan Perspektif. Surakarta: STSI Press.

Suwandi. 2007. Bentuk Dan Fungsi Kesenian Rodad Di Desa Jati Lawang Kecamatan Wonosegoro Kabupaten Boyolali. Skripsi Jurusan Pendidikan Seni Drama Tari Dan Musik. Fakultas Bahasa Dan Seni. Universitas Negeri Semarang.

Suyitno, A.Md. 2007. Pengenalan Penelitian. Yogyakarta: UNY Press.

Widyastutieningrum, Sri Rochana dan Dwi Wahyudiarto. 2014. Pengantar Koreografi. Surakarta: ISI Surakarta. 


\section{LAMPIRAN}

\section{Lampiran 1 Instrumen Penelitian}

JUDUL:

"ESTETIKA BENTUK PERTUNJUKAN TARI LENGGANG PARI DI SANGGAR SENI PERWITASARI KELURAHAN KEMANDUNGAN KECAMATAN TEGAL BARAT KOTA TEGAL” 


\section{PEDOMAN OBSERVASI}

\subsection{Bagaimana Gambaran Umum Lokasi Penelitian}

1.1.1 Gambaran umum lokasi penelitian yaitu Sanggar Seni Perwitasari Kelurahan Kemandungan Kecamatan Tegal Barat Kota Tegal

1.1.2 Keadaan lingkungan dan kodisi fisik lokasi penelitian

1.1.3 Letak geografis lokasi penelitian

\subsection{Bagaimana kondisi penduduk}

1.2.1 Jumlah penduduk menurut umur

1.2.2 Jumlah penduduk menurut pendidikan

1.2.3 Jumlah penduduk berdasarkan agama yang dianut

1.2.4 Jumlah penduduk berdasarkan mata pencaharian

1.2.5 Jumlah fasilitas umum

\subsection{Bagaimana bentuk pertunjukan tari Lenggang Pari}

1.3.1 Latar belakang penciptaan tari Lenggang Pari

1.3.2 Ragam gerak tari Lenggang Pari

1.3.3 Rias wajah dan busana yang digunakan

1.3.4 Iringan/musik yang digunakan

1.3.5 Tata lampu dan tata suara yang digunakan

1.3.6 Tempat pentas yang digunakan

1.3.7 kapan waktu pertunjukan tari Lenggang Pari

1.3.8 Properti apa yang digunakan

1.3.9 Nilai keindahan bentuk tari Lenggang Pari

\section{PEDOMAN WAWANCARA}




\subsection{Wawancara dengan ketua atau pemimpin sanggar seni perwitasari}

\subsubsection{Sejak kapan sanggar seni perwitasari berdiri ?}

2.1.2 Bagaimana struktur sanggar seni perwitasari ?

2.1.3 Berapa lama Anda menjadi Ketua pengelola sanggar seni perwitasari ?

2.1.4 Berapa jumlah penari di sanggar seni perwitasari ?

2.1.5 Bagaimana latar belakang penciptaan tari Lenggang Pari di sanggar seni perwitasari ?

2.1.6 Dimana saja tempat pentas tari Lenggang Pari dan dalam rangkaian acara apa ?

2.1.7 Siapa saja yang terlibat dalam pementasan tari Lenggang Pari ?

2.1.8 Persiapan apa saja yang dilakukan guna menunjang pementasan tari Lenggang Pari ?

2.1.9 Apa arti nama Lenggang Pari?

2.1.10 Lenggang Pari ini penggambaran dari apa?

2.1.11 Bagaimana bentuk pertunjukan tari Lenggang Pari?

2.1.12 Ragam gerak apa saja dalam tari Lenggang Pari?

2.1.13 Apa saja tata lampu dan tata suara yang digunakan ?

2.1.14 Bagaimana bakat yang dimiliki oleh penari dan pemusik?

2.1.15 Apa yang menjadi daya tarik dan keunikan tari Lenggang Pari ?

2.1.16 Apakah ada syarat khusus untuk menjadi penari tari Lenggang Pari ?

2.1.17 Apa saja prestasi sanggar seni perwitasari?

2.1.18 Bagaimana cara regenerasi penari di sanggar seni perwitasari ?

2.1.19 Bagaimana cara membuat kostum tari Lenggang Pari ? 
2.1.20 Bagaimana iringannya/musiknya?

2.1.21 Apa daya tarik tari Lenggang Pari?

2.1.22 Properti apa yang digunakan dalam pementasan tari Lenggang Pari ?

2.1.23 Bagaimana nilai estetika atau nilai keindahan yang ada dalam pementasan tari Lenggang Pari ?

\subsection{Wawancara dengan penari}

2.2.1 Berapa lama sudah menjadi penari di sanggar seni perwitasari ?

2.2.2 Adakah syarat tertentu untuk menjadi penari tari Lenggang Pari ?

2.2.3 Darimana Anda mendapatkan bakat dan keterampilan menari ?

2.2.4 Siapa yang melatih Anda tari Lenggang Pari ?

2.2.5 Bagaimana cara berlatihnya dan regenerasinya ?

2.2.6 Adakah jadwal rutin untuk berlatih tari Lenggang Pari ?

2.2.7 Adakah latihan khusus sebelum adanya pementasan tari Lenggang Pari ?

2.2.8 Apa kendalanya dalam berlatih ?

2.2.9 Siapa saja penarinya ?

2.2.10 Apa saja kostum yang Anda kenakan pada saat menari tari Lenggang Pari $?$

2.2.11 Bagaimana iringan/musiknya ?

2.2.12 Bagaimana pembagian penari dalam tari Lenggang pari?

2.2.13 Bagaimana gerak dalam tari Lenggang Pari ?

2.2.14 Bagaimana bentuk tata rias dan tata busana yang digunakan?

2.2.15 Apa saja urutan penyajian dalam pementasan tari Lenggang Pari ?

2.2.16 Properti apa yang digunakan dalam pementasan tari Lenggang Pari ? 
2.2.17 Apa yang menjadi daya tarik penari dalam tari Lenggang Pari ?

2.2.18 Bagaimana nilai keindahan bentuk tari Lenggang Pari menurut Anda?

\subsection{Wawancara dengan pemusik}

2.3.1 Berapa lama sudah menjadi pemusik di sanggar seni perwitasari ?

2.3.2 Apa saja instrumen yang digunakan dalam pembuatan musik iringan tari Lenggang Pari ?

2.3.3 Jenis laras dan gending apa yang digunakan?

2.3.4 Berapa personil dalam pembuatan musik tari Lenggang Pari ?

2.3.5 Bagaimana urutan penyajian gendhing dan tembangan dalam penyajian tari Lenggang pari ?

2.3.6 Adakah gending atau tembang khusus yang harus digunakan?

2.3.7 Musik apa saja yang diadopsi dalam tari Lenggang Pari ?

2.3.8 Apa nilai estetis yang ada dalam tari Lenggang Pari ?

\subsection{Wawancara dengan perangkat Kelurahan Kemandungan Kecamatan} Tegal Barat Kota Tegal

2.4.1 Dimana letah geografis Kelurahan Kemandungan?

2.4.2 Bagaimana kondisi fisik wilayah Kelurahan Kemandungan?

2.4.3 Bagaimana data statistik kependudukan Kelurahan Kemandungan ?

\section{PEDOMAN DOKUMENTASI}

3.1 Peta wilayah Kelurahan Kemandungan

3.2 Data statistik Kelurahan Kemandungan

3.3 Video pementasan tari Lenggang Pari 
3.4 Foto pementasan tari Lenggang Pari

3.5 Foto tata rias wajah dan busana penari Lenggang Pari

3.6 Foto instrumen/media yang digunakan dalam tari Lenggang Pari

3.7 Foto pelaku (penari/pemusik) tari Lenggang Pari

3.8 Foto ragam gerak tari Lenggang Pari

3.9 Foto properti yang digunakan

3.10 Foto lokasi penelitian yaitu di Sanggar Seni Perwitasari Kelurahan Kemandungan Kecamatan Tegal Barat Kota Tegal

3.11 Foto wawancara dengan berbagai narasumber

\section{Lampiran 2 Surat Keterangan Dosen Pembimbing}

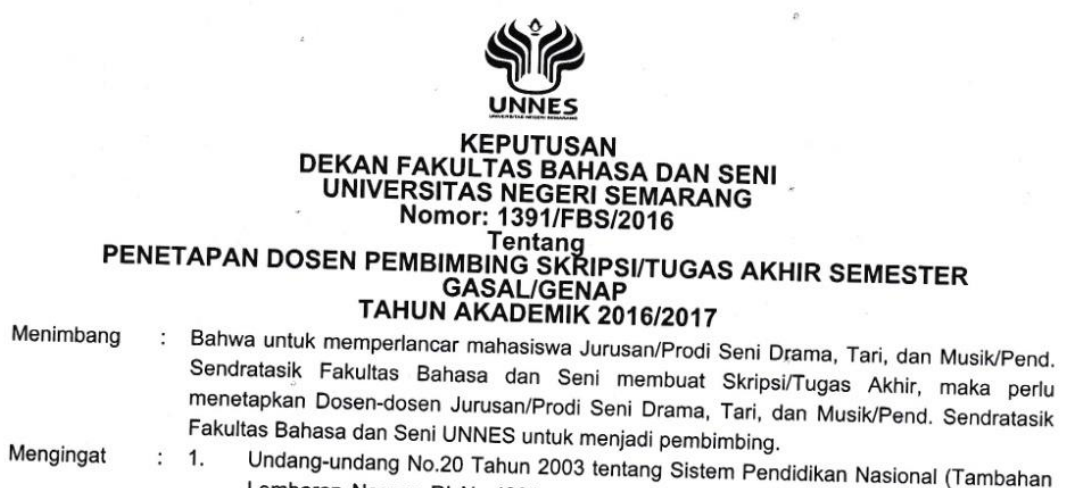




\title{
Lampiran 3 Surat Permohonan Izin Penelitian
}

\author{
(2) KEMENTERIAN RISET, TEKNOLOGI, DAN PENDIDIKAN TINGGI \\ UNIVERSITAS NEGERI SEMARANG \\ FAKULTAS BAHASA DAN SENI \\ Gedung B, Kampus Sekaran, Gunungpati, Semarang 50229 \\ Telepon +62248508010, Faksimile +62248508010
Laman: http://fbs.unnes.ac.id, Email: fbs@unnes.ac.id \\ Nomor : 2548/UN37.1.2/LT/2017 \\ Lamp. : :- \\ Hal. : Permohonan Izin Penelitian \\ Yth. Kepala Kelurahan Kemandungan Kecamatan Tegal Barat Kota Tegal \\ di tempat
}

Dengan hormat kami beritahukan bahwa dalam rangka penyusunan skripsi mahasiswa kami, 
KEMENTERIAN RISET, TEKNOLOGI, DAN PENDIDIKAN TINGGI UNIVERSITAS NEGERI SEMARANG

FAKULTAS BAHASA DAN SENI

Gedung B, Kampus Sekaran, Gunungpati, Semarang 50229

Telepon +62248508010 , Faksimile +62248508010 Laman: http://fbs.unnes.ac.id, Email: fbs@unnes.ac.id

Nomor : 2548/UN37.1.2/LT/2017

Lamp. : :

Hal. : Permohonan Izin Penelitian

Yth. Ketua Sanggar Seni Perwitasari, Kel. Kemandungan Kota Tegal

di tempat

Dengan hormat kami beritahukan bahwa dalam rangka penyusunan skripsi mahasiswa kami,

nama

DEVVI LUTFIANA

nim : 2501413072

jurusan : SENDRATASIK

program studi : PENDIDIKAN SENI TARI

jenjang : : 1

tahun akademik S1 


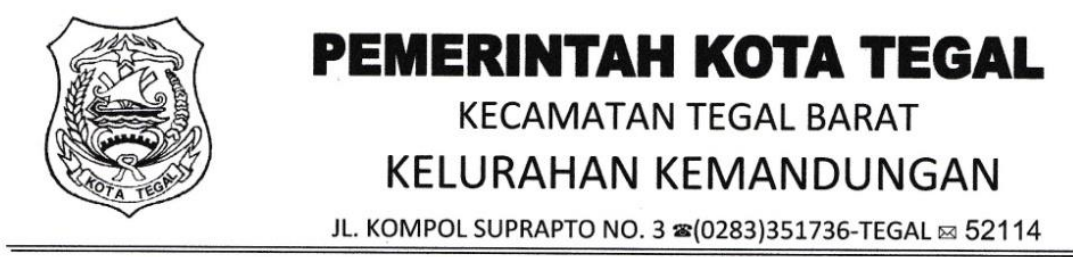

SURAT KETERANGAN PENELITIAN

Nomor : $140 / 08 \mathbf{2}$ 


\section{SANGGAR SENI PERWITASARI}

Jl. SUKARDI NO.32 KELURAHAN KEMANDUNGAN KECAMATAN TEGAL BARAT KOTA TEGAL 08156949018 凶 52114

\section{SURAT BUKTI PENELITIAN}

Yang bertanda tangan di bawah ini:

Nama

: Priambodo

Alamat : J1. Sukardi No.32 Kel. Kemandungan Kec. Tegal Barat Kota Tegal

Jabatan : Ketua Sanggar Seni Perwitasari

Menerangkan dengan sesungguhnya bahwa: 
Lampiran 5 Dokumentasi Pengambilan Data

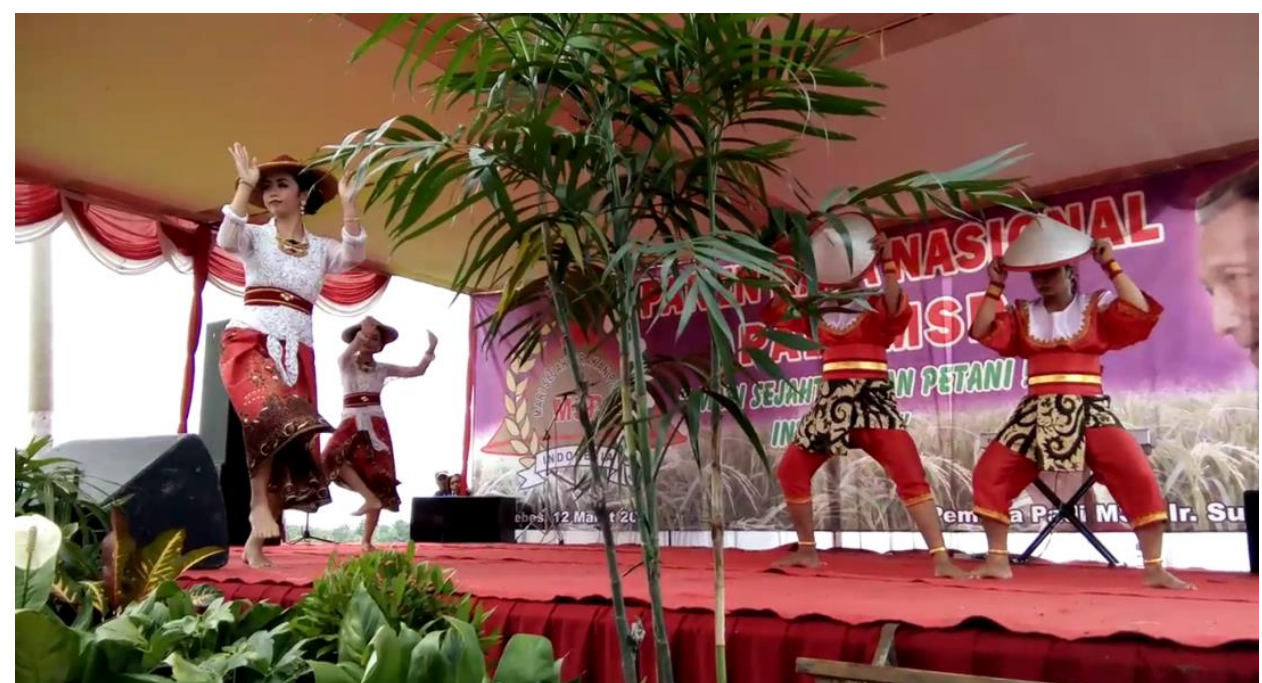


Dok. 1 Penampilan penari di atas Panggung

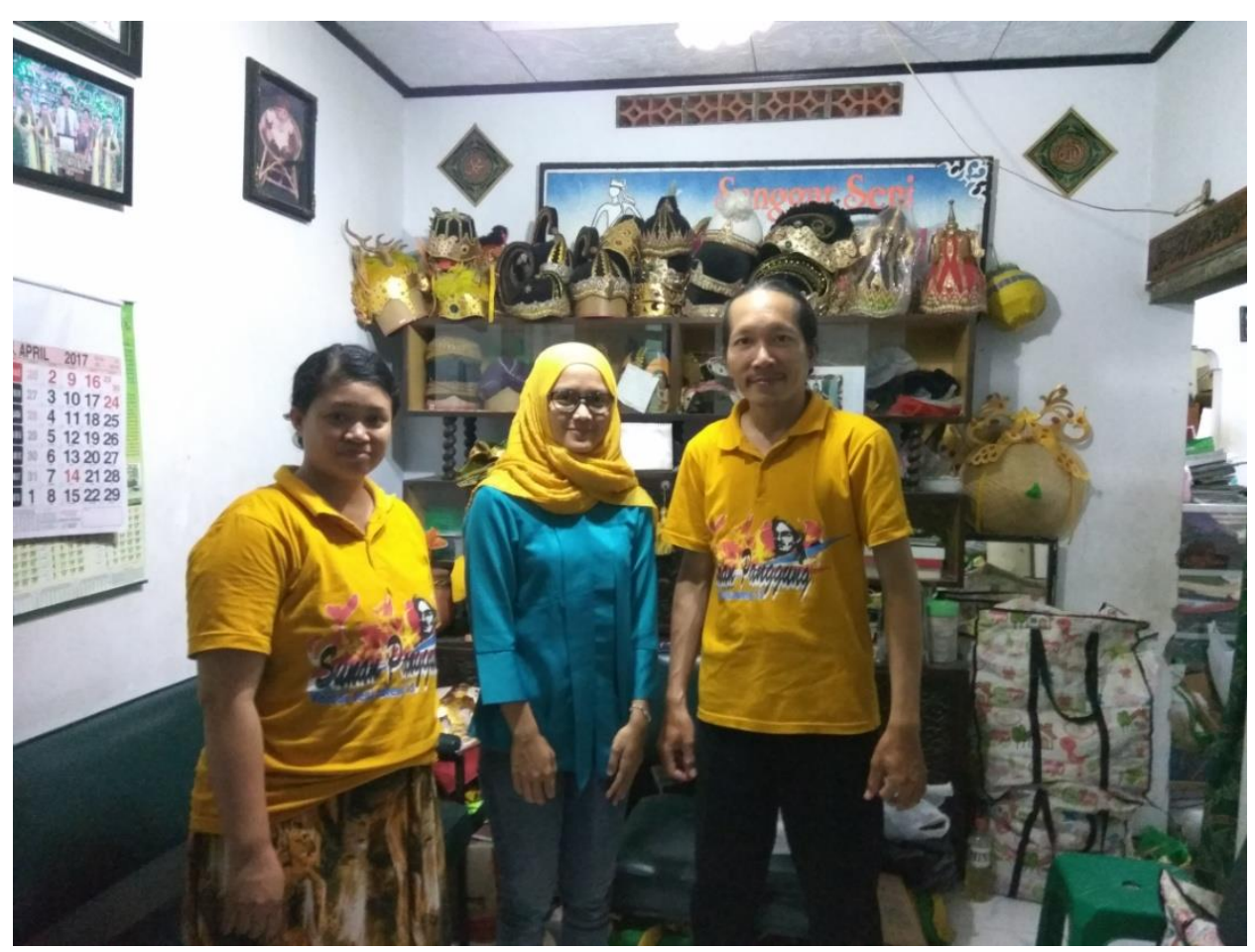

Dok. 2 Peneliti bersama narasumber Damayanti

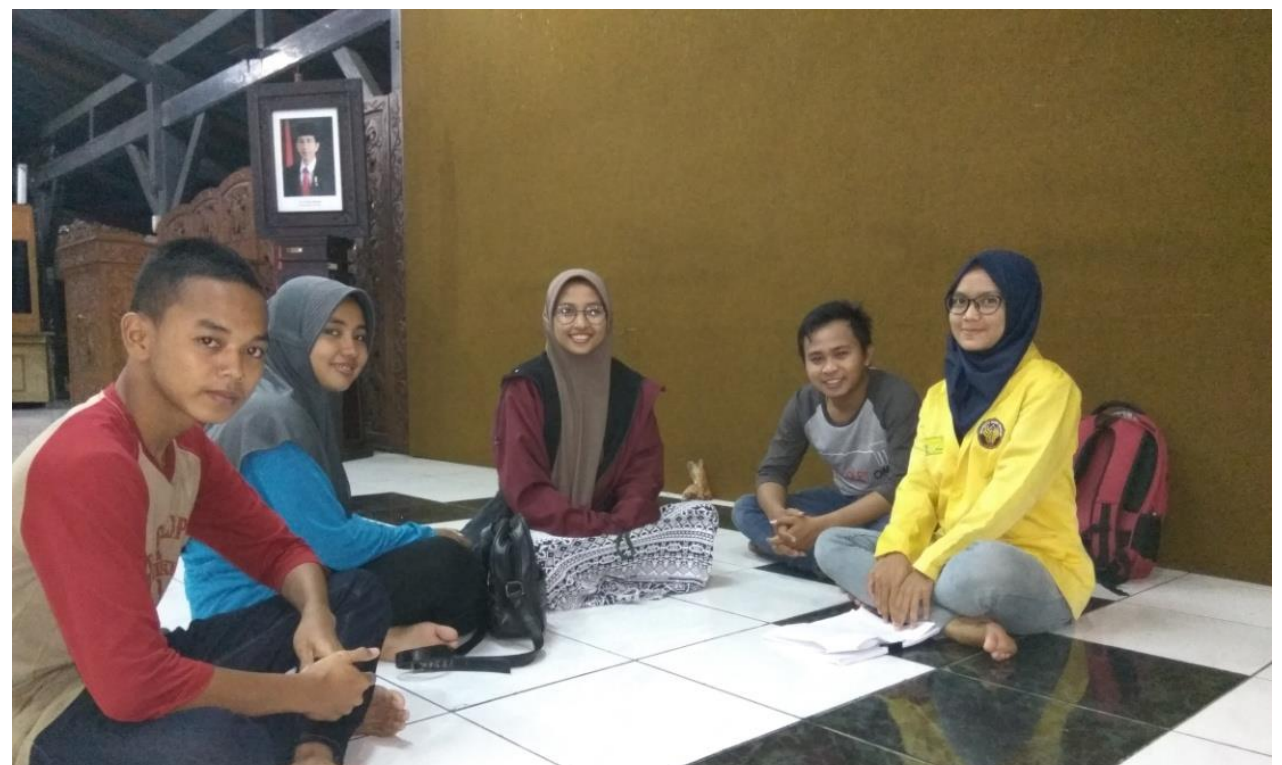


Dok. 3 Peneliti bersama narasumber Wike, Deri, Zulfa, dan Dimas

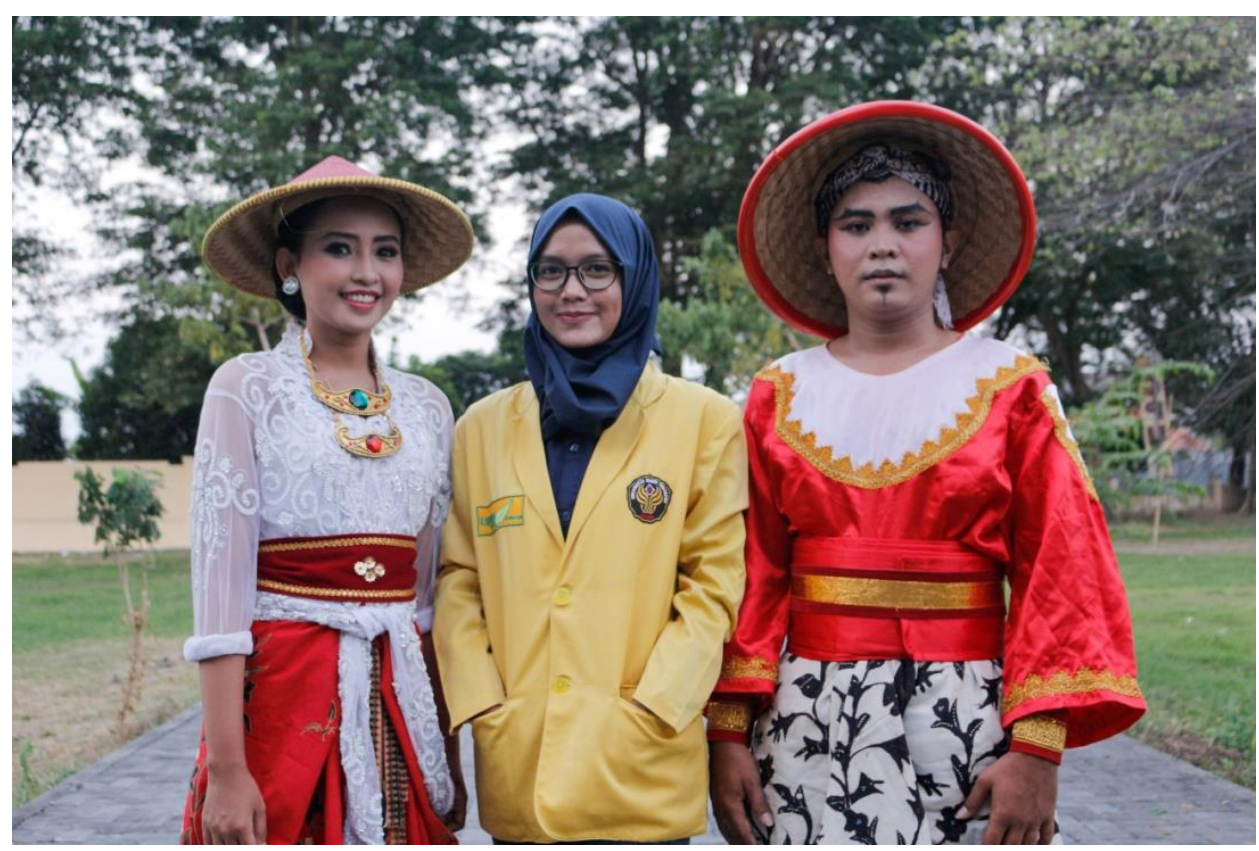

Dok. 4 Peneliti bersama penari tari Lenggang Pari

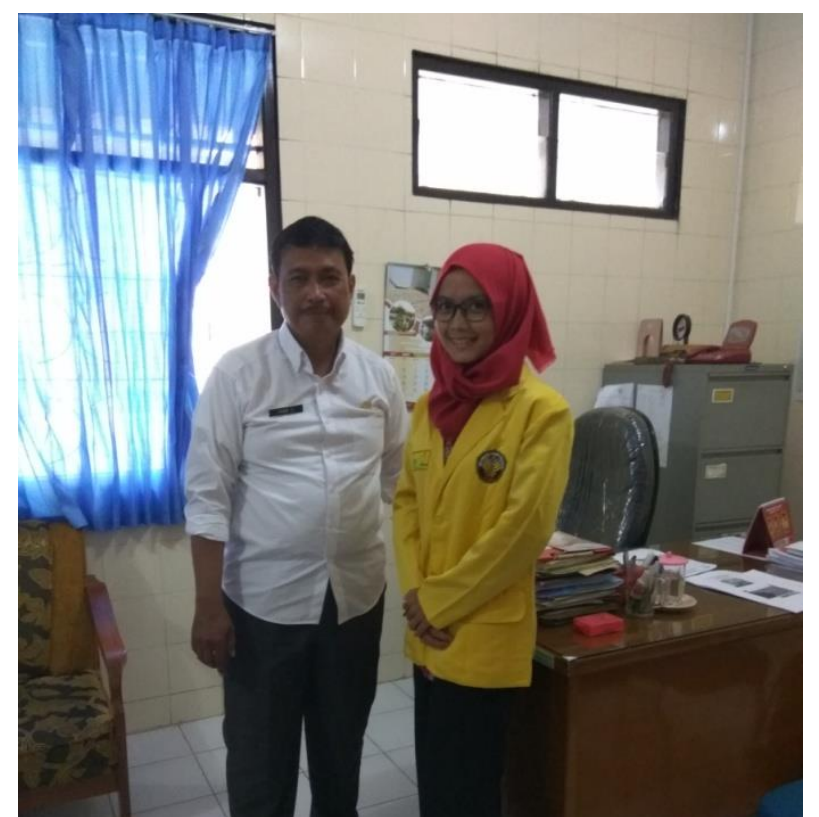


Dok. 5 Peneliti bersama narasumber Imam Surokhim

\section{Lampiran 6 Biodata Narasumber}

1. Nama : Sri Damayanti

Tempat, tanggal lahir : Malang, 30 Juni 1978

Pekerjaan

: Dosen Universitas Pancasakti Tegal

Alamat

: Jl. Sukardi No.32 Kemandungan

Jabatan

: Penata dan Pelatih Tari Sanggar Seni Perwitasari 
2. Nama

Tempat, tanggal lahir

Pekerjaan

Alamat

Jabatan

3. Nama

Tempat, tanggal lahir

Pekerjaan

Alamat

Jabatan

4. Nama

Tempat, tanggal lahir

Pekerjaan

Alamat

Jabatan

5. Nama

Tempat, tanggal lahir

Pekerjaan

Alamat

Jabatan

6. Nama

Tempat, tanggal lahir

Pekerjaan

Alamat

Jabatan

7. Nama
: Priambodo

: Tegal, 3 Juli 1977

: Seniman

: Jl. Sukardi No.32 Kemandungan

: Pimpinan Sanggar Seni Perwitasari

: Imam Surokhim

: Tegal, 15 Agustus 1976

: Lurah

: J1. Sukardi No.53 Kemandungan

: Lurah Kelurahan Kemandungan

: Fatkhudin Tri Nugroho

: Tegal, 25 Januari 1990

: Guru SMP Negeri 14 Kota Tegal

: Ds. Balamoa Kec. Pangkah

: Penata Musik Sanggar Seni Perwitasari

: Zulfa Prabowo

: Tegal, 26 Juni 2017

: Wirausaha

: Margadana Kec. Tegal Barat

: Penari Sanggar Seni Perwitasari

: Dimas Gilang Maulana

: Tegal, 2 April 1996

: Seniman

: Perum Karlita Kec. Tegal Selatan

: Penari Sanggar Seni Perwitasari

: Wike Yuliani 
Tempat, tanggal lahir $\quad$ : Brebes, 28 Mei 1994

Pekerjaan : Mahasiswi

Alamat

: Jl. Kh. Ahmad Dahlan Pasarbatang Brebes

Jabatan

: Penari Sanggar Seni Perwitasari

8. Nama

: Deri Putri Asih

Tempat, tanggal lahir

: Tegal, 30 Maret 1995

Pekerjaan

: Mahasiswi

Alamat

: J1. Nakula Pasar Krandon Kota Tegal

Jabatan

: Penari Sanggar Seni Perwitasari

Lampiran 7 Data Daftar Nama Siswa di Sanggar Seni Perwitasari

\begin{tabular}{|c|l|c|c|c|}
\hline No. & \multicolumn{1}{|c|}{ Nama } & Umur & Pekerjaan & Kelompok \\
\hline 1. & Adya & 11 tahun & Siswa & Pemula \\
\hline 2. & Denada & 14 tahun & Siswa & Pemula \\
\hline 3. & Putri & 12 tahun & Siswa & Pemula \\
\hline 4. & Umrotul & 11 tahun & Siswa & Pemula \\
\hline 5. & Intan & 13 tahun & Siswa & Pemula \\
\hline 6. & Sinta & 14 tahun & Siswa & Pemula \\
\hline
\end{tabular}




\begin{tabular}{|c|c|c|c|c|}
\hline 7. & Hawa & 11 tahun & Siswa & Pemula \\
\hline 8. & Amelia & 14 tahun & Siswa & Pemula \\
\hline 9. & Wandi & 12 tahun & Siswa & Pemula \\
\hline 10. & Rimbawan & 15 tahun & Siswa & Pemula \\
\hline 11. & Abdul & 14 tahun & Sswa & Pemula \\
\hline 12. & \begin{tabular}{|l} 
Syahrul \\
\end{tabular} & 15 tahun & Siswa & Pemula \\
\hline 13. & Saeful & 11 tahun & Siswa & Pemula \\
\hline 14. & Afrizan & 12 tahun & Siswa & Pemula \\
\hline 15. & Rizal & 14 tahun & Siswa & Pemula \\
\hline 16. & Iqbal & 14 tahun & Siswa & Pemula \\
\hline 17. & Abdan & 15 tahun & Siswa & Pemula \\
\hline 18. & Rifki & 12 tahun & Siswa & Pemula \\
\hline 19. & Andrean & 15 tahun & Siswa & Pemula \\
\hline 20. & Kurniadi & 14 tahun & Siswa & Pemula \\
\hline 21. & Amrillah & 14 tahun & Siswa & Pemula \\
\hline 22. & Ahmad & 16 tahun & Siswa & Pemula \\
\hline 23. & Tegar & 15 tahun & Siswa & Pemula \\
\hline 24. & Arrisky & 14 tahun & Siswa & Pemula \\
\hline 25. & Intan & 18 tahun & Mahasiswa & Lanjut \\
\hline 26. & Yuma & 17 tahun & Mahasiswa & Lanjut \\
\hline 27. & Mirkhatun & 16 tahun & Siswa & Lanjut \\
\hline 28. & Puji & 17 tahun & Siswa & Lanjut \\
\hline 29. & Rizqi & 18 tahun & Mahasiswa & Lanjut \\
\hline 30. & Hesti & 18 tahun & Mahasiswa & Lanjut \\
\hline 31. & Maghfiroh & 17 tahun & Mahasiswa & Lanjut \\
\hline 32. & Damar & 17 tahun & Mahasiswa & Lanjut \\
\hline 33. & Wahyu & 16 tahun & Siswa & Lanjut \\
\hline 34. & Pratama & 17 tahun & Siswa & Lanjut \\
\hline 35. & Daffa & 16 tahun & Siswa & Lanjut \\
\hline 36. & \begin{tabular}{|l|} 
Dimantoro \\
\end{tabular} & 17 tahun & Mahasiswa & Lanjut \\
\hline 37. & Naufal & 18 tahun & Mahasiswa & Lanjut \\
\hline 39. & Bayu & 24 tahun & Perawat & Mahir \\
\hline 40. & Deri & 22 tahun & Mahasiswa & Mahir \\
\hline 41. & Zulfa & 23 tahun & Wirausaha & Mahir \\
\hline 42. & Dimas & 23 tahun & Wiraswasta & Mahir \\
\hline 43. & Wike & 22 tahun & Mahasiswa & Mahir \\
\hline 44. & Panji & 20 tahun & Mahasiswa & Mahir \\
\hline 45. & Lia & 24 tahun & Wiraswasta & Mahir \\
\hline 46. & Dwi & 24 tahun & Wiraswasta & Mahir \\
\hline 47. & Fifit & 24 tahun & Teller & Mahir \\
\hline 48. & Avika & 17 tahun & Siswa & Mahir \\
\hline 49. & Nelson & 19 tahun & Mahasiswa & Mahir \\
\hline 50. & Dea & 17 tahun & Siswa & Mahir \\
\hline
\end{tabular}


Lampiran 8

BIODATA PENELITI

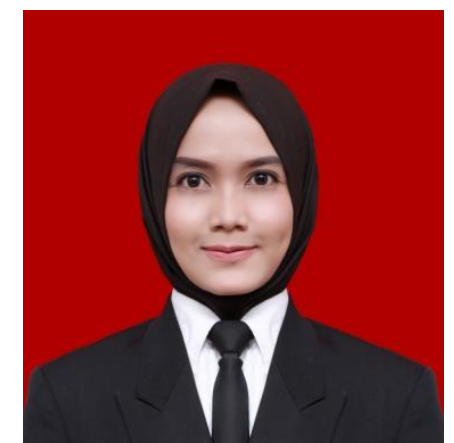




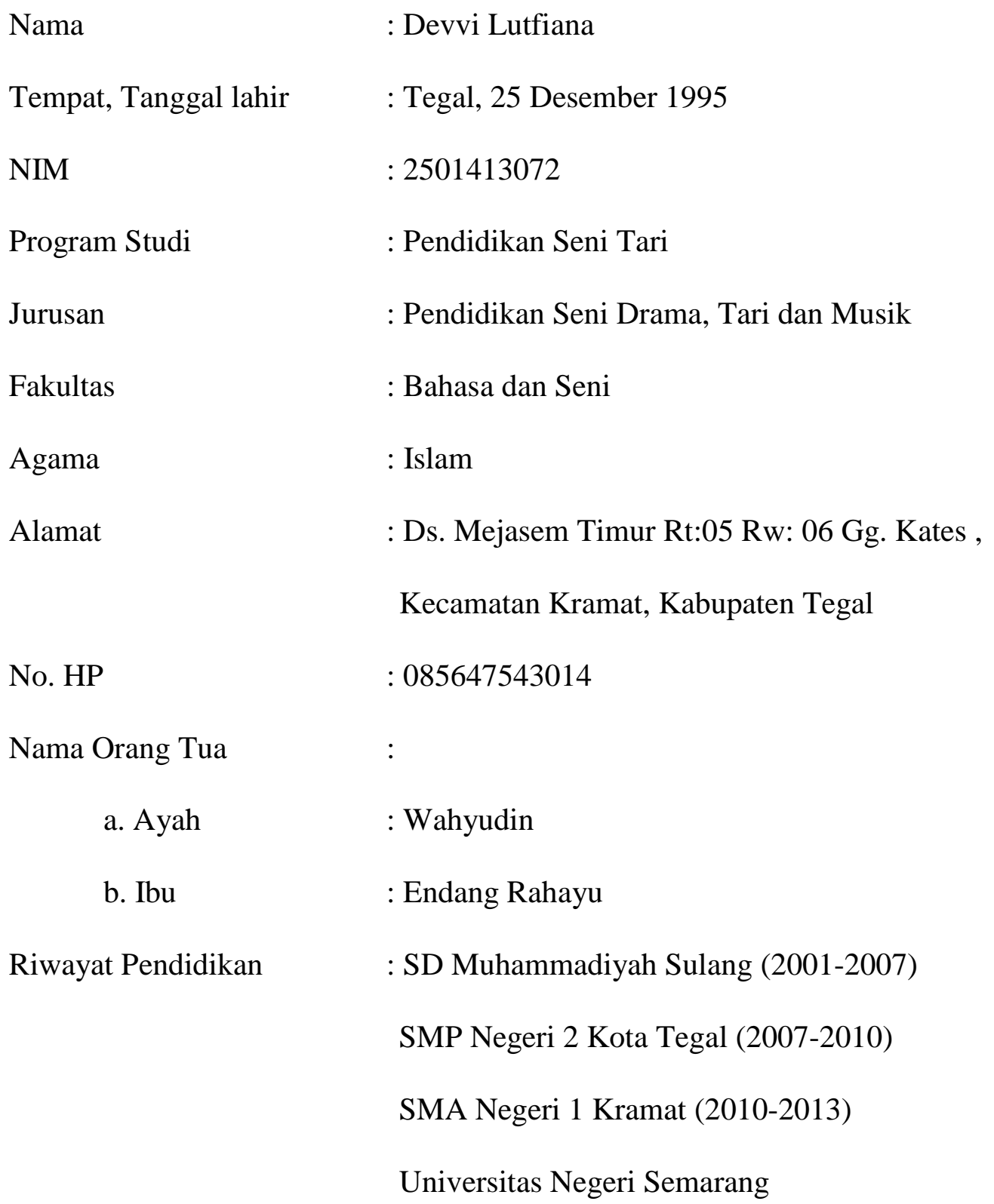

